\author{
UNIVERSIDADE DE SÃO PAULO \\ INSTITUTO DE GEOCIENCIAS \\ DEPARTAMENTO DE MINERALOGIA E GEOTECTONNICA
}

\title{
INTERAÇÕES FLUIDO-ROCHA EM METADOLOMITOS DA PORÇÃO MERIDIONAL DO GRUPO ITAIACOCA, PARANÁ
}

Fábio Ramos Dias de Andrade

Tese apresentada para Concurso de Livre.Docência junto ao Departamento de Mineralogia e Geotectônica do Instituto de Geociências da Universidade de São Paulo, na área de conhecimento Mineralogia Básica e Aplicada. 
UNIVERSIDADE DE SÃO PAULO

INSTITUTO DE GEOCIÊNCIAS

DEPARTAMENTO DE MINERALOGIA E GEOTECTÔNICA

\section{INTERAÇÕES FLUIDO-ROCHA EM METADOLOMITOS DA PORÇÃO MERIDIONAL DO GRUPO ITAIACOCA, PARANÁ}

Fábio Ramos Dias de Andrade

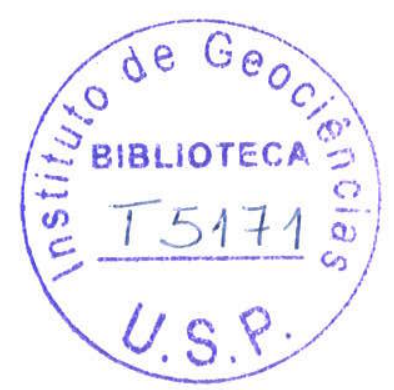

DEDALUS - Acervo - IGC

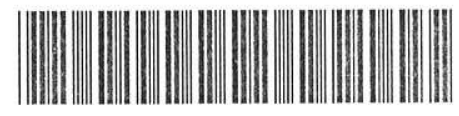

30900030764

Tese apresentada para Concurso de Livre-Docência junto ao Departamento de Mineralogia e Geotectônica do Instituto de Geociências da Universidade de São Paulo na área de concentração Mineralogia Básica e Aplicada

São Paulo 


\section{Índice}

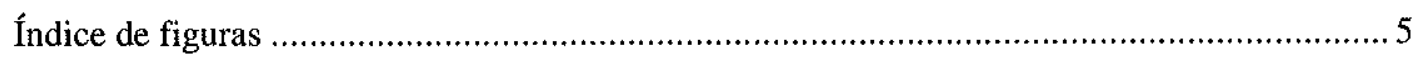

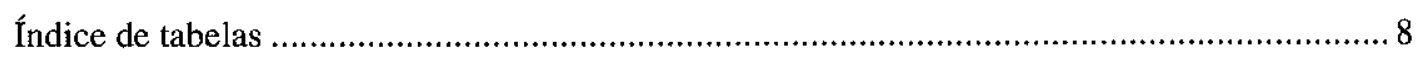

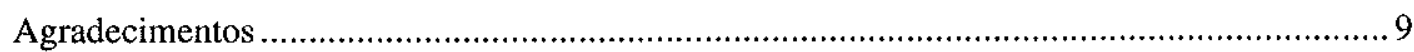

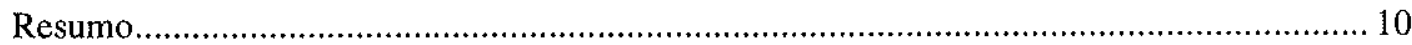

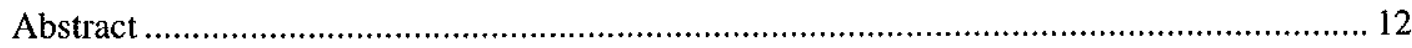

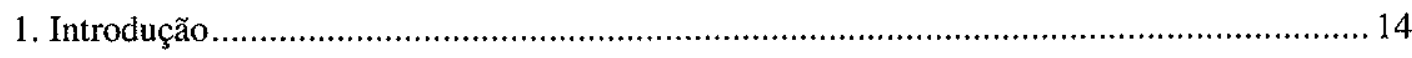

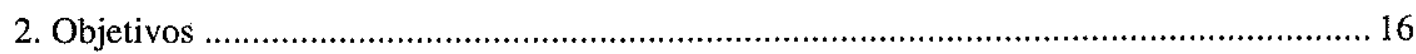

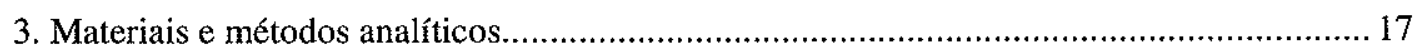

3.1. Amostragem em campo e petrografia ......................................................... 17

3.2. Microscopia eletrônica de varredura........................................................... 17

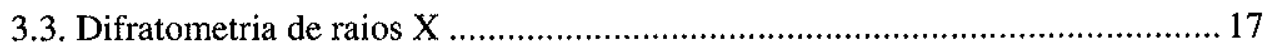

3.4. Química de rocha total e de minerais......................................................... 19

3.5. Análises de isótopos estáveis de carbono e oxigênio ...................................... 19

3.6. Microtermometria de inclusões fluidas.......................................................... 20

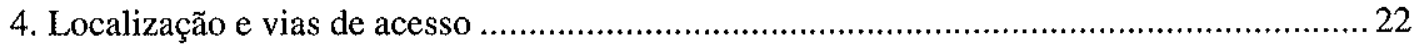

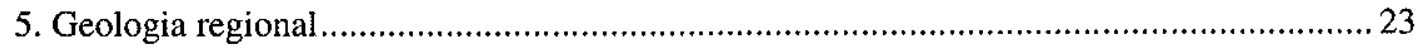

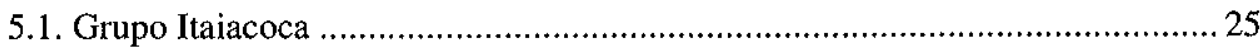

6. Talco: geologia econômica, estatísticas e usos industriais................................................ 31

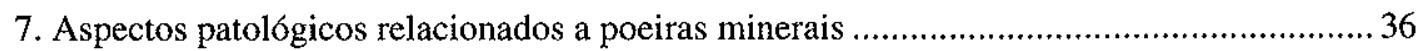

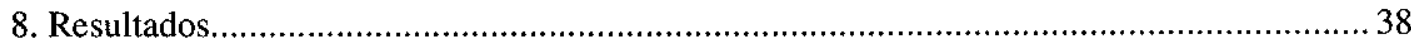




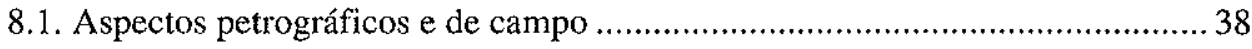

8.1.1. Protolito dolomítico e metamorfismo regional........................................... 38

8.1.2. Metamorfismo dinâmico-hidrotermal ....................................................... 42

8.1.3. Metamorfismo termal I - Complexo Granítico Cunhaporanga.................. 46

8.1.4. Metamorfismo termal II - enxame de diques de diabásio ......................... 48

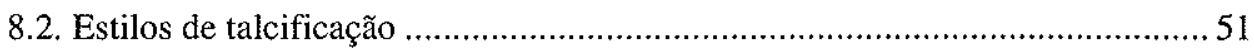

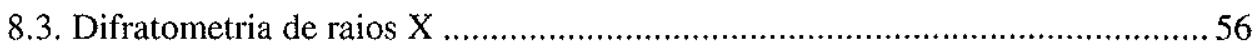

8.3.1. Análise qualitativa e semi-quantitativa de fases......................................56

8.3.2. Difratometria de raios $\mathrm{X}$ e método de Rietveld .........................................59 59

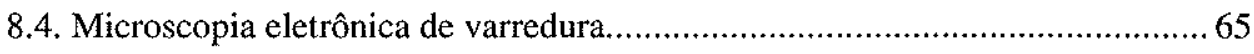

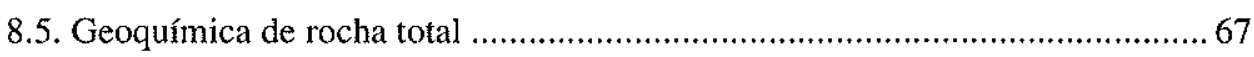

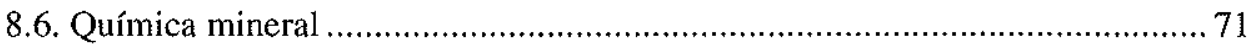

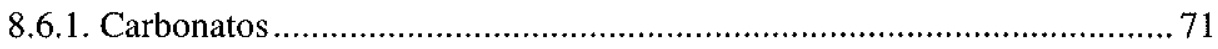

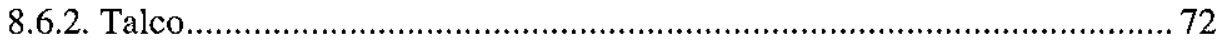

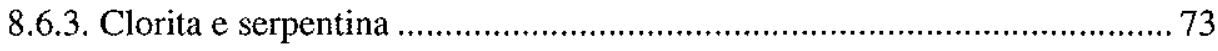

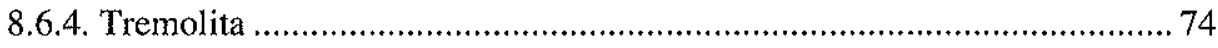

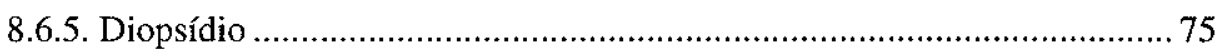

8.7. Isótopos estáveis de carbono e oxigênio …………………….......................... 75

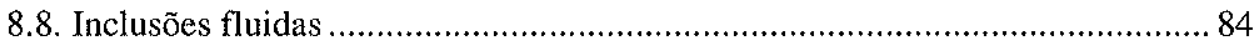

8.8.1. Inclusões fluidas em zonas de cisalhamento ............................................... 84

8.8.2. Inclusões fluidas na auréola de contato do Complexo Granítico

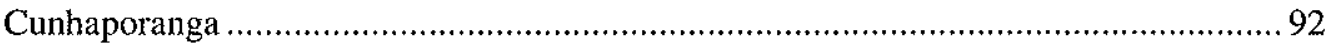

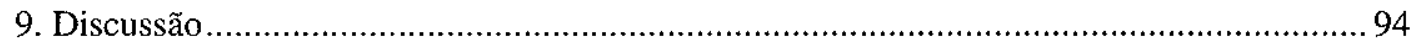

9.1. A dolomita original e a dolomitização no Grupo Itaiacoca ............................ 94

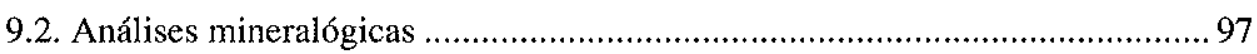

9.3. Metamorfismo e talcificação no Grupo Itaiacoca ......................................... 101

9.3.1. Metamorfismo dinâmico-hidrotermal .................................................... 104

9.3.2. Metamorfismo de contato I ................................................................. 109

9.3.3. Metamorfismo de contato II ............................................................... 112

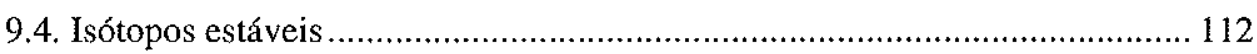

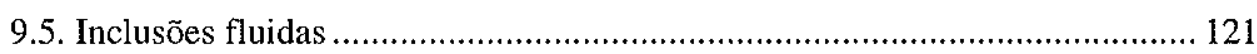

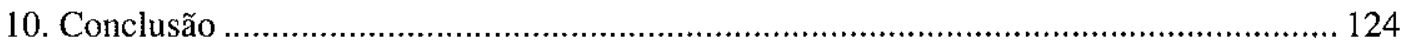

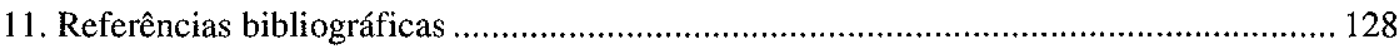

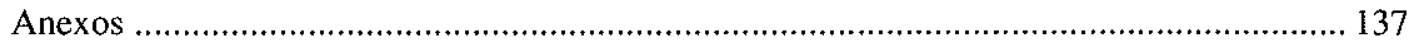




\section{Índice de figuras}

Figura 1. Mapa de localizaçăo e acesso à área de estudo (fonte www.googlemaps.com).........................22

Figura 2. Mapa geológico regional, simplificado de Campanha e Sadowski (1999). Abreviações: $g m=$ Complexo Gnáissico-Migmatítico; $c a p=$ Formação Capiru; $v t=$ Grupo Votuverava; $a c=$ Formação Água Clara; $i t=$ Grupo Itaiacoca; $T C=$ Complexo Granítico Três Córregos; $\mathbf{C P}=$ Complexo Granítico Cunhaporanga.

Figura 3. Mapa geológico do Grupo Itaiacoca entre Itaiacoca e Socavão, Estado do Paraná (modificado de CPRM, 1977)

Figura 4. Participação dos Estados nas estatísticas brasileiras sobre o talco ano-base 2005 (DNPM, 2006a), (a) Reservas nacionais (total 115,5 milhões de toneladas); (b) valor da produção (total $\mathbf{R} \$ 56$ milhões)

Figura 5. Produção de talco e respectivos valores no Brasil, ano-base 2005 (DNPM, 2006a).................. 35

Figura 6. Aspecto em afloramento da superfície original de sedimentação $\left(\mathrm{S}_{0}\right)$ subhorizontal dos metadolomitos do Grupo Itaiacoca (ponto PTI 01) (a) em afloramento; (b) detalhe de camadas de grãos de quartzo em lâmina petrográfica.

Figura 7. Estruturas sedimentares em metadolomito: (a) estromatólitos em afloramento; (b) estromatólitos em amostra de mão; (c) oólitos em lâmina petrográfica (ponto PTI 22) ..................................................40

Figura 8. Brechas não-tectônicas em vista panorâmica e de detalhe (ponto PTI 01) . ..............................40

Figura 9. Brechas tectônicas em afloramento (ponto PTI 01): (a) sobreposição de uma brecha com matriz menos abundante sobre uma brecha anterior, com abundante matriz carbonática branca; (b) detalhe da brecha com moagem e transporte pouco pronunciado de clastos.

Figura 10. Talco xisto milonítico em zona de cisalhamento transcorrente (ponto PTI 22). As faixas anastomosadas onde se concentra a deformação mais intensa (à direita) envolvem frações metadolomíticas preservadas em graus variados (à esquerda). (a) afloramento; (b) amostra de mão.; (c) lâmina petrográfica, porfiroclasto de metadolomito fragmentado e rotacionado na matriz talcosa; (d) lâmina petrográfica, porfiroblasto de calcita $\mathrm{em}$ meio à matriz talcosa.

Figura 11. Borda de uma zona de cisalhamento transcorrente com mineralização tipo talco xisto (ponto PTI 22). (a) espaçamento regular de faixas miloníticas com talco xisto (faixas claras) cortando o metadolomito; (b) detalhe de plano de foliação milonítica anastomosada; (c) detalhe de foliação milonítica cortando a estratificação original (So)

Figura 12. Aparente transição local de regime de deformação rúptil (brechas) para regine dúctil (foliação com talco) na porção central da imagem (ponto PTI 01)

Figura 13. Mármore dolomítico nas proximidades do contato intrusivo entre o Complexo Granítico Cunhaporanga e o Grupo Itaiacoca. (a) visão panorâmica em afloramento; (b) detalhe de estrutura concêntrica de metamorfismo de contato, com paragêneses de temperatura mais alta na parte central (forsterita, diopsídio, tremolita) e mais baixa nas bordas (talco, quartzo, dolomita); (c) tremolita acicular em matriz carbonática granoblástica (polarizadores cruzados); (d) tremolita acicular bordejada por calcita (polarizadores paralelos com tingimento diferencial - calcita incolor, dolomita azul).

Figura 14. Fotomicrografia com polarizadores cruzados de metapelito com andalusita na zona de metamorfismo de contato entre o Complexo Granítico Cunhaporanga e o Grupo Itaiacoca.

Figura 15. Contato intrusivo entre os diques de diabásio mesozóicos e o Grupo Itaiacoca (ponto PT102). (a) visão panorâmica em afloramento, vide trator na parte superior direita da foto para escala; (b) xenólito de metadolomito na borda de dique de diabásio; (c) fotomicrografia com polarizadores cruzados da porção central de dique de diabásio, com textura fanerítica fina (microgabro); (d) fotomicrografia com polarizadores cruzados da borda de dique de diabásio, com textura afanítica.............................................50

Figura 16. Metadolomito na zona de contato com os diques de diabásio mesoź́icos, com planos e bolsōes

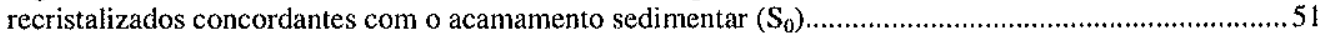

Figura 17. Blocos-diagramas com croquis dos estilos de talcificação no Grupo Itaiacoca. 53 
Figura 18. Mapa geológico simplificado do Grupo Itaiacoca entre Itaiacoca e Socavão (modificado de CPRM, 1977), com indicação das principais jazidas de talco, metadolomito e mármore dolomítico........55

Figura 19. Difratogramas de raios X para comparação entre amostra moída em moinho de panela de ágata e amostra desagregada por via úmida e depositada em porta-amostras de vidro. A diferença na intensidade entre as amostras se deve ao maior volume de amostra analisado na amostra moída. A escala absoluta de intensidade consta apenas por referência e foi alterada para permitir a melhor comparação das amostras.

Figura 20. Difratogramas de raios $\mathrm{X}$ de três amostras de talco puro provenientes do ponto PTI 02 (talco xisto), nos intervalos angulares $5-12^{\circ}$ e $18-40^{\circ}$. A escala absoluta de intensidade consta apenas por referência e foi alterada para permitir a melhor comparação das amostras. As amostras foram desagregadas por via úmida.....

Figura 21. Difratogramas de raios $X$ de amostras de talco de talco xisto e de talco maciço fino. A escala absoluta de intensidade consta apenas por referência e foi alterada para permitir a melhor comparação das amostras. As amostras foram desagregadas por via úmida..

Figura 22. Gráficos de Rietveld com comparação entre modelos de estruturas.

Figura 23. Imagens de elétrons retroespalhados obtidas por microscopia eletrônica de varredura. (a) talco xisto com tremolita (PTI22L); (b) talco xisto com tremolita (PTI22L); (c) talco maciço fino em intersecção de fraturas (PTI42A); (d) tremolita mármore dolomítico, com talco retrometamórfico (PTI07JI) $($ dol $=$ dolomita; $\mathrm{cc}=$ calcita; tc $=$ talco; $\mathrm{tr}=$ tremolita $)$.

Figura 24. Imagens de elétrons secundários obtidas por microscopia eletrônica de varredura. (a) minério de talco puro (PTI02AQ2); (b) talco lamelar em detalhe (PTI02AQ2); (c) associação tremolita+quartzo (PTI22J); (d) tremolita fibrosa em detalhe (PTI09AA1) (cc = calcita; tc = talco; tr = tremolita; qz = quartzo).

Figura 25. Composição química de rocha total, diagramas triangulares $\mathrm{CaO}-\mathrm{MgO}-\mathrm{SiO}_{2}$ (proporção

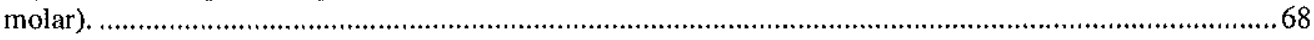

Figura 26. Composição química de rocha total, diagramas multielementos normalizados por

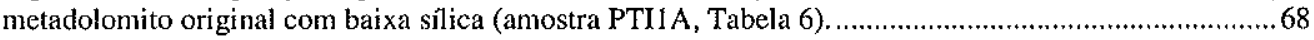

Figura 27. Composição de calcita e dolomita. (a) diagrama triangular $\mathrm{CaO}-\mathrm{MgO}-\mathrm{FeO}$ (propr. molares); (b) diagrama $\mathrm{Ca}$ versus $\mathrm{Mg}$ (a.p.f.u.) das mesmas amostras...................................................................72

Figura 28. Variação composicional de talco, Si versus $\mathrm{Al}$ (a.p.f.u.) ...................................................... 73

Figura 29. Variação composicional de tremolita de talco xisto e de mármore dolomítico, Si versus $\mathrm{Al}$

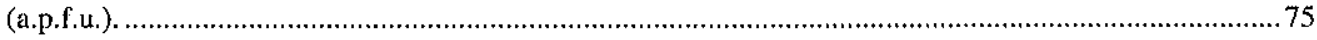

Figura 30. Razões de isótopos estáveis de carbono e oxigênio de carbonatos do Grupo Itaiacoca...........77

Figura 31. Razões isotópicas de carbono e oxigênio de pares coexistentes de dolomita e calcita..............78

Figura 32. Razões isotópicas de carbono e oxigênio de pares clasto-matriz em metadolomito brechado.. 79

Figura 33. Fracionamento isotópico de carbono $\left(1000 \mathrm{ln} \alpha^{13} \mathrm{C}_{(\mathrm{dol}-\mathrm{cc})}\right)$ e de oxigênio (1000ln $\left.\alpha^{18} \mathrm{O}_{(\mathrm{dot}-\mathrm{cc})}\right)$ em pares coexistentes de dolomita e calcita. A reta $\mathbf{A}$ representa a linha de equilíbrio isotópico entre dolonita e calcita (Sheppard e Schwarcz, 1970).

Figura 34. Histogramas de temperatura eutética $\left(\mathrm{Te}^{\circ} \mathrm{C}\right.$ ), amostra PTI $02 \mathrm{AI}$ (calcita)...........................86

Figura 35. Histogramas de temperatura de fusão do gelo (Tfg ${ }^{\circ} \mathrm{C}$ ), amostra PTI 02 AI (calcita)............. 87

Figura 36. Histogramas de salinidade, amostra PTI 02 AI (calcita)...................................................... 88

Figura 37. Histogramas de temperatura de homogeneização total, amostra PTI 02 AI (calcita)............... 90

Figura 38. Temperatura de homogeneização total versus temperatura de fusão do gelo, e temperatura de homogeneização total versus salinidade amostra PTI 02 AI (calcita); em vermelho inclusões primárias ou pseudo-secundárias, em azul um conjunto de inclusões possivelmente secundárias................................91

Figura 39. Modelo de formação de dolomita-dorag. (A) Solubilidade da calcita em função da pressão parcial de $\mathrm{CO}_{2}$. Quando as soluções saturadas A e B se misturam, as composições sobre a linha de mistura tracejada $\mathrm{AB}$ são insaturadas em relação a calcita; $(\mathrm{B})$ Solubilidade da calcita em relação à salinidade; (C) Curvas de solubilidade de dolomita e calcita em mistura de água salgada / água doce. A 
dolomitização ocorre na zona onde a mistura é insaturada $\mathrm{em}$ relação à calcita e saturada em relação à dolomita (zona dorag)

Figura 40. Geotermometria de carbonatos a partir de $\mathrm{X}_{\mathrm{Mg}}$ em calcita coexistente com dolomita, segundo equação de Pulan (1995)

Figura 41. Modelo simplificado da evolução geológica do Grupo Itaiacoca na região do Arco de Ponta Grossa, Paraná.

Figura 42. Diagrama de fases pseudo-binário $\mathrm{T}\left({ }^{\circ} \mathrm{C}\right) \times \mathrm{X}_{\mathrm{CO} 2}$ para o sistema dolomita - calcita - quartzo a $0,5 \mathrm{~kb}$ (apud Holness, 1992).

Figura 43. Curvas calculadas de fracionamento isotópico de carbono e oxigênio de calcita em rochas talcificadas, considerando: $\mathrm{X}_{\mathrm{CO} 2}=0,05$; temperaturas de $300^{\circ} \mathrm{C}$ (curva cheia) e $200^{\circ} \mathrm{C}$ (curva tracejada); composição inicial da calcita $\delta^{13} \mathrm{C}=1,3 \% 0 ; \delta^{18} \mathrm{O}=24,2 \%$; composição inicial do fluido $\delta^{13} \mathrm{C}=-5 \%$; $\delta^{18} \mathrm{O}=3 \%$. Os números ao longo das curvas representam a razão fluido:rocha. 117

Figura 44. Curvas calculadas de fracionamento isotópico de carbono e oxigênio de dolomita em rochas talcificadas, considerando: $\mathrm{X}_{\mathrm{CO} 2}=0,05$; temperaturas de $300^{\circ} \mathrm{C}$ (curva cheia) e $200^{\circ} \mathrm{C}$ (curva tracejada); composição inicial da dolomita $\delta^{13} \mathrm{C}=2,4 \%$; $\delta^{18} \mathrm{O}=26 \%$; composição inicial do fluido $\delta^{13} \mathrm{C}=-5 \%$; $\delta^{18} \mathrm{O}=3 \%$. Os números ao longo das curvas representam a razão fluido:rocha.

Figura 45. Curvas calculadas de fracionamento isotópico de carbono e oxigênio de dolomita em rochas brechadas, considerando: $\mathrm{X}_{\mathrm{CO} 2}=0,10$; temperaturas de $400^{\circ} \mathrm{C}$ (curva cheia); $300^{\circ} \mathrm{C}$ (curva tracejada); $200^{\circ} \mathrm{C}$ (curva pontilhada); e $150^{\circ} \mathrm{C}$ (curva tracejada-pontilhada); composição inicial da dolomita $\delta^{13} \mathrm{C}=$ $2,4 \%$; $\delta^{18} \mathrm{O}=26 \%$; composição inicial do fluido $\delta^{13} \mathrm{C}=-5 \%$; $\delta^{18} \mathrm{O}=3 \%$. Os números ao longo das curvas representam a razăo fluido:rocha. 


\section{Índice de tabelas}

Tabela 1. Propostas de empilhamento estratigráfico para o Grupo Itaiacoca (modificada DNPMMineropar, 1999).

Tabela 2. Estimativas da produção de talco em toneladas, ano-base 2005, segundo DNPM (2007) e USGS (2007)

Tabela 3. Reservas medida de talco no Brasil em toneladas, ano-base 2005 (DNPM, 2006a).

Tabela 4. Estimativas da produção e valores de talco no Brasil, ano-base 2005 (DNPM, 2006a)

Tabela 5. Análise mineralógica semi-quantitativa por difratometria de raios $\mathrm{X}$ de amostras encaminhadas para análise isotópica de carbono e oxigênio $(\mathrm{cc}=\mathrm{calcita} ; \mathrm{dol}=$ dolomita; $\mathrm{qz}=$ quartzo; tc $=$ talco; $\mathrm{ct}=$

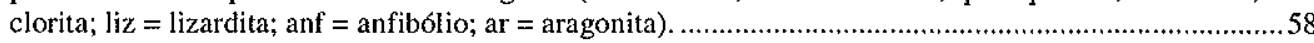

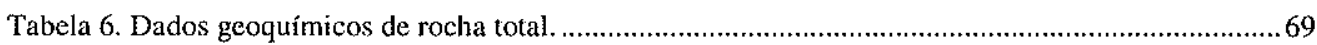

Tabela 7. Dados de isótopos estáveis de carbono e oxigênio, de variedades litológicos do Grupo Itaiacoca $(\mathrm{cc}=\mathrm{calcita} ;$ dol=dolomita; $\mathrm{ar}=$ aragonita $)$

Tabela 8. Intervalos de valores de isótopos estáveis de carbono e oxigênio de acordo com o tipo litológico.

Tabela 9. Fração molar de componentes e densidade de fluidos calculados a partir de dados de microtermometria. 


\section{Agradecimentos}

Meus sinceros agradecimentos ao colega Gergely Andres Julio Szabó, que participou de todas as etapas deste projeto, contribuindo com sua sabedoria e coleguismo. Agradeço a Gilson Burigo Guimarães por nos ter sugerido o estudo das jazidas de talco do Paraná e pela sua participação desde os primórdios do projeto. Devo especial gratidão à colega Rosa Bello pelo seu empenho em analisar inclusões fluidas, em discutir os dados e em nos ensinar como isto é feito cuidadosamente.

Gostaria de agradecer às secretárias Sônia Gomes e Valéria Santos do Departamento de Mineralogia e Geotectônica pela ajuda diária e ao suporte técnico gentilmente fornecido por Flávio Machado da Silva Carvalho (difratometria de raios X), Marcos Mansueto (microssonda eletrônica), Sandra Andrade e Paulo Mori (química de rocha total), Isaac Sayeg (microscopia eletrônica de varredura), Luís Mancini (isótopos estáveis) e Erickson Zanon (informática). Muito obrigado à Marta José da Silva, pela enorme ajuda na organização de documentos e na preparação do memorial para este concurso.

Muito obrigado aos amigos Luiz Eduardo Anelli, Ciro Teixeira Correia, Caetano Juliani, Excelso Ruberti, Eliane Aparecida Del Lama, Valdecir de Assis Janasi, Bernhard Buehn, Yushiro Kihara, Marcelo Pecchio, Lucelene Martins, Silvio Vlach, Mabel e Horstpeter Ulbrich, Oswaldo siga Jr., Renato Moraes, Mário Campos Neto, Daniel Atencio, Maria Helena de Hollanda e aos que injustamente foram esquecidos nesta lista.

Agradeço aos estudantes do curso de Geologia da USP que estagiaram conosco em diversas etapas deste projeto.

Este trabalho foi financiado pela FAPESP através de dois projetos de auxílio à pesquisa $(2000 / 03115-3 ; 2005 / 55551-5)$ e contou com apoio de Projeto Temático (1997/00640-5) e das empresas de mineração que permitiram acesso às lavras.

Finalmente, dedico este volume a toda a minha família, especialmente a Francini, Diego, Jorge e Clara (in memoriam). 


\section{Resumo}

O Grupo Itaiacoca é composto predominantemente por rochas metadolomíticas de baixo grau metamórfico que contêm expressivas reservas de talco. O Grupo Itaiacoca foi submetido a quatro episódios metamórficos: (i) metamorfismo regional fácies xisto verde, zona da clorita; (ii) metamorfismo dinâmico e hidrotermal em zonas de cisalhamento transcorrentes; (iii) metamorfismo termal no contato com o Complexo Granítico Cunhaporanga; e, finalmente, (iv) metamorfismo termal no contato com diques de diabásio mesozóicos que cortam o Grupo Itaiacoca ao longo do Arco de Ponta Grossa. A talcificação está relacionada à atividade hidrotermal nas zonas de cisalhamento, que gerou talco xistos com foliação anastomosada envolvendo lentes residuais de metadolomito e lentes sintectônicas de calcita. Jazidas de talco maciço fino, com o talco concentrado em descontinuidades estruturais sem alteração significativa de volume, estão associadas a zonas de fraturas periféricas aos sistemas de cisalhamento, sem a influência direta da deformação milonítica. Quantidades subordinadas de talco retrometamórfico formaram-se a partir de tremolita na auréola de metamorfismo de contato com o Complexo Granítico Cunhaporanga. Não se observou talco associado aos metadolomitos afetados por metamorfismo regional ou pela auréola de metamorfismo de contato dos diques. A principal reação de talcificação da dolomita por reação com soluções aquosas com sílica foi 3dolomita +4 sílica $_{\mathrm{aqq}}=$ talco $+3 \mathrm{Ca}^{2+}{ }_{\mathrm{aqq}}+6 \mathrm{CO}_{2}$. A mineralogia dos minérios de talco é simples, com talco xisto compostos por talco, calcita, quartzo, dolomita, e quantidades menores de clorita, serpentina e tremolita. A mineralogia dos minérios, além de isótopos estáveis de carbono e oxigênio, e inclusões fluidas indicam que os fluidos mineralizantes tinham muito baixa $\mathrm{X}_{\mathrm{CO} 2}$, devido à percolação de grandes volumes de água nos planos de cisalhamento, com relação fluido:rocha superior a 500:1 em volume, o que diluiu quase totalmente o $\mathrm{CO}_{2}$ liberado na descarbonatação e talcificação. Dados de geotermometria de carbonatos apontam para temperaturas próximas a $400^{\circ} \mathrm{C}$ para o pico da talcificação. No metamorfismo de contato próximo ao granito, as temperaturas foram mais elevadas $\left(\sim 500^{\circ} \mathrm{C}\right)$ e a disponibilidade de $\mathrm{CO}_{2}$ no fluido foi maior, pela menor disponibilidade de fluidos externos. Com isto, as paragêneses evoluíram no sentido da formação de tremolita ao invés de talco, este se formando apenas em quantidades subordinadas por retrometamorfismo. 
As soluções hidrotermais que promoveram a talcificação percolaram o metadolomito através das zonas de cisalhamento, planos de fraturas e descontinuidades estruturais, devido ao gradiente geotérmico elevado, provocado pela presença dos dois batólitos graníticos que delimitam o Grupo Itaiacoca, ambos colocados no Ciclo Brasiliano, ao final do qual se instalaram as zonas de cisalhamento transcorrentes às quais se associam as principais jazidas de talco da região. $O$ gradiente geotérmico foi o fator chave para a geração de talco no Grupo Itaiacoca. Uma evidência disto é a inexistência de talco na Formação Capiru, situada próxima ao Grupo Itaiacoca, de idade semelhante, com composição dolomítica, e igualmente afetada por zonas de cisalhamento e por diques de diabásio. Entretanto, enquanto o Grupo Itaiacoca se situava numa crosta aquecida pelos batólitos graníticos, a Formação Capiru foi empurrada por falhas de cavalgamento por sobre uma crosta fria, composta por migmatitos arqueanos do Complexo Atuba. $\mathrm{O}$ calor liberado pelas rochas graníticas assegurou a circulação suficiente de fluidos para a transformação dos metadolomitos de Itaiacoca em talco. 


\section{Abstract}

The Itaiacoca Group, Paraná State, southern Brazil, is composed mainly by metadolomites of low metamorphic grade, and contains large talc deposits. This group was affected by four metamorphic episodes: (i) greenschist facies, chlorite zone regional metamorphism; (ii) dynamic and hydrothermal metamorphism along transcurrent shear zones; (iii) thermometamorphism at the contact with the Cunhaporanga Granitic Complex; and, finally, (iv) thermometamorphism at the contact with the diabase diques that cross cut the Itaiacoca Group along the Ponta Grossa Arch. Talcification is related to the hydrothermal activity along the shear zones, that formed talc schists with anastomosed foliation envolving lense-shaped fragments of metadolomite and sintectonic calcite. Deposits of massive, fine-grained talc were also formed, where talc is concentrated in structural discontinuities, without expressive volume change or mylonitic deformation. Minor amounts of retrograde talc were formed after tremolite in the contact aureolas close to the border of Cunhaporanga Granitic Complex. There was no talc formation related to the regional metamorphism or to the emplacement of the diabase diques. Talc was formed by the reaction of dolomite with a silica-bearing aqueous solution, through the reaction 3 dolomite +4 silica $_{\mathrm{aq}}=$ talc $+3 \mathrm{Ca}^{2+}{ }_{a q}+6 \mathrm{CO}_{2}$. Ore mineralogy is simple, composed by talc, calcite, quartz and dolomite, with minor amounts of chlorite, serpentine and tremolite, of restricted occurrence. Ore mineralogy, carbon and oxygen stable isotopes and fluid inclusion data point to mineralizing fluids with very low $\mathrm{X}_{\mathrm{CO} 2}$, since water:rock ratios were $>500: 1$ in volume, which diluted the $\mathrm{CO}_{2}$ generated by the dolomite decomposition. Calcite $\mathrm{X}_{\mathrm{Mg}}$ geothermometry points to temperatures around $400^{\circ} \mathrm{C}$ to the main stage of talc formation. Temperatures were higher at the contact with the granite $\left(\sim 500^{\circ} \mathrm{C}\right)$ and the $\mathrm{CO}_{2}$ concentration in the fluid was also higher, due to minor input of external fluids in this context, and, therefore, paragenesis in this case evolved towards tremolite formation instead of talc.

Talc-forming hydrothermal solutions percolated the metadolomite along shear zones, fractures and structural discontinuities, driven by high geothermal gradient caused by the two neighbouring granite batholits emplaced during the Brasiliano Orogenic Cycle. Geothermal gradient was a key parameter for talc formation in the 
Itaiacoca Group. This is supported by the absence of talc in the neighbour Capiru Formation, which has similar age, similar dolomitic composition, and which was also affect by shear zones and diabase diques. While the Itaiacoca Group was in a hot continental crust due to the granite batholiths, the Capiru Formation was transported by wrench faults toward a cold crust, made by archean migmatites of the Atuba Complex. The heat of the granite batholiths made possible the circulation of huge volumes of hydrothermal solutions through the Itaiacoca metadolomites, leading to the formation of talc deposits. 


\section{Introdução}

O Grupo Itaiacoca pertence aos terrenos neoproterozóicos dos Estados do Paraná e São Paulo e registra uma complexa história metamórfica com quatro eventos metamórficos, que são metamorfismo regional, metamorfismo dinâmico com hidrotermalismo associado, e dois eventos distintos de metamorfismo termal, o primeiro no Neoproterozóico e o segundo no Cretáceo. Os produtos destes quatro episódios metamórficos são visíveis na porção sul do Grupo Itaiacoca, na região de Itaiacoca Socavão. Tanto as variáveis intensivas pressão e temperatura, como os demais fatores (regime tectônico, origem e composição dos fluidos, razões fluido:rocha, estilos de percolação) foram contrastantes nestes quatro eventos metamórficos. A homogeneidade original dos protólitos dolomíticos favorece a comparação entre produtos gerados nestes eventos metamórficos e, à exceção do metamorfismo regional homogenamente presente em toda a unidade, os registros dos processos metamórficos superimpostos têm distribuição espacial que permite analisá-los individualmente.

Os metadolomitos do Grupo Itaiacoca contêm as maiores reservas de talco do Brasil (DNPM, 2006a) e diversos modelos foram propostos para a sua origem. Barbosa (1943) e Sobanski et al. (1984) atribuíram a talcificação ao metamorfismo de contato dos diques de diabásio cretáceos do Arco de Ponta Grossa. Lima $(1992,1997)$ e Lima e Dardenne (1987) reconheceram uma primeira geração de talco associada ao metamorfismo regional e a falhas de cavalgamento, e uma segunda geração relacionada à percolação de fluidos superficiais hidrotermais em falhas transcorrentes de direção nordeste, cuja circulação teria sido provocada pelo aquecimento provocado pelos granitos vizinhos ao Grupo Itaiacoca. O relatório DNPM-MINEROPAR (1999) sobre as jazidas paranaenses de talco, atribui sua origem ao metamorfismo e ao percolamento de fluidos em falhas de cavalgamento e fraturamentos subverticais, plano-axiais a dobras abertas, e à alteração superficial, retrabalhamento e reconcentração do talco metamórfico.

O presente estudo pretende discutir os modelos de interação fluido-rocha nestes metadolomitos, em particular nos sistemas relacionados à gênese de talco. A interação fluido-rocha é uma das principais vias de transformação de materiais geológicos na crosta terrestre e, apesar de sua importância petrológica e econômica, é relativamente 
pouco estudada em sistemas relacionados à concentração de bens não-metálicos. A análise da talcificação por interação fluido-rocha em zonas de cisalhamento e em dois sistemas distintos de metamorfismo de contato permitiu identificar com relativo detalhe os processos neoproterozóicos e mesozóicos que afetaram a crosta continental na região que hoje constitui o Grupo Itaiacoca. Estes dados foram interpretados no contexto das regiões vizinhas e comparados com ocorrências geologicamente semelhantes. Parte dos dados e discussões apresentados neste trabalho encontram-se publicados em artigos recentes (Szab6 et al., 2004, 2006; Andrade et al, 2005, in prep.). 


\section{Objetivos}

O presente trabalho tem como objetivo reconstituir os fenômenos de interação fluido-rocha nos metadolomitos do Grupo Itaiacoca, com ênfase nos sistemas formadores de talco. As principais questões que tentamos responder com este etudo foram:

- como se formaram as jazidas de talco do Grupo Itaiacoca?

- qual a relação entre talcificação e história metamórfica?

- quais as variáveis intensivas e extensivas do processo de talcificação?

- como foram as interações fluido-rocha neste processo?

O estudo foi feito em diversas escalas de observação, desde o reconhecimento regional da distribuição e diversidade das jazidas, passando pela descrição detalhada de afloramentos selecionados, até a análise em laboratório das amostras consideradas representativas das principais feições observadas em campo. $\mathrm{O}$ uso combinado de petrografia por microscopia óptica, microscopia eletrônica de varredura, difratometria de raios $\mathrm{X}$, geoquímica de rocha total, química mineral e análises microtermométricas em inclusões fluidas permitiu a formulação de modelos dos processos geológicos, particularmente os hidrotermais, transcorridos na região de estudo.

Não fizeram parte dos objetivos deste trabalho o mapeamento geológico do Grupo Itaiacoca, nem contribuir para a discussão de sua paleoestratigrafia e geocronologia, ou de sua inserção no contexto geotectônico da Faixa Ribeira. 


\section{Materiais e métodos analíticos}

\subsection{Amostragem em campo e petrografia}

As análises petrográficas e mineralógicas foram realizadas em amostras de metadolomitos, mármores dolomíticos, além as rochas associadas (filitos, rochas metabásicas, granitos, diabásio). Foram preparadas seções delgadas convencionais e seções não recobertas por lamínula, para realização de tingimento seletivo de carbonatos com azul de lizarina (dolomita - azul; calcita - incolor; Hutchison, 1974). As descrições petrográficas foram realizadas no Instituto de Geociências da USP.

\subsection{Microscopia eletrônica de varredura}

A microscopia eletrônica de varredura foi usada na obtenção de imagens de elétrons secundários e retroespalhados, com análises químicas qualitativas por foram obtidas em equipamento LEO440i, no Instituto de Geociências da USP, corrente 20kV, com distância de trabalho de $25 \mathrm{~mm}$ e diâmetro do feixe de $\sim 3 \mu \mathrm{m}$, em amostras recobertas por carbono. Análises químicas puntuais qualitativas foram realizadas com detector de espectro de energia dispersiva (energy dispersive spectra, EDS). Imagens adicionais por elétrons secundários por microscopia eletrônica de varredura foram obtidas com corrente $20 \mathrm{kV}$ em amostras recobertas por ouro, em equipamento Philips do Centro Experimental Aramar da Marinha do Brasil em Iperó, SP.

\subsection{Difratometria de raios $\mathrm{X}$}

As análises por difratometria de raios $\mathrm{X}(\mathrm{DRX})$ em amostras de pó foram feitas em amostras de minério de talco coletadas in situ, minério bruto extraído e estocado "tal-qual", minério pré-beneficiado por separação granulométrica em peneiras em rampa e catação manual, minério beneficiado (cominuído, peneirado, seco em forno). As análises foram feitas no Instituto de Geociências da USP em difratômetro Siemens D5000 com tubo de cobre $\left(\mathrm{Cu} \mathrm{K}_{\alpha}\right)$ operando com $40 \mathrm{kV}$ e $40 \mathrm{~mA}$ equipado com colimador de feixe do tipo espelho de Goebel. A primeira etapa das análises foi voltada à identificação rotineira de fases (varredura em passos de $0,05^{\circ} / \mathrm{s}$ e intervalo angular $(2 \theta)$ entre $3^{\circ}$ e $65^{\circ}$ ), e a segunda voltada à análise estrutural do talco pelo método de 
Rietveld (varredura em passos de $0,02^{\circ}$, com velocidade de 10 segundos por passo, e intervalo angular $(2 \theta)$ de $5^{\circ}$ a $120^{\circ}$ ). Os difratogramas foram interpretados utilizando o banco de dados JCPDS-ICDD e o programa Diffrac AT PLUS. Amostras contendo asbestos foram preparadas em caixa de luvas (glove box), com o uso de máscaras de proteção específicas.

A análise difratométrica pelo método desenvolvido por Rietveld (1969) foi feita visando a análise quantitativa de fases e a identificação das características estruturais entre talco procedente de diferentes contextos geológicos no Grupo Itaiacoca. As amostras de talco puro foram preparadas de duas maneiras distintas: (a) moagem em moinho de disco e (b) desagregação com pistilo de ágata em solução aquosa, seguido de decantação sobre porta-amostras de vidro. A estratégia de refinamento dos difratogramas calculados levou em conta os seguintes parâmetros: (i) seleção dos modelos de estrutura das fases presentes; (ii) refinamento da radiação de fundo (background) pelo polinômio de Chebyshev modificado de ordem 8; (iii) fator de escala individual para cada fase presente no caso das amostras polifásicas; (iv) parâmetros de cela $(a, b, c, \alpha, \beta, \gamma)$ e deslocamento dos picos de difração (shift) refinados em conjunto, sendo o deslocamento corrigido no mesmo sentido e quantidade para todos os picos de todas as fases (shift constraint); (v) parâmetros de perfil de pico, incluindo assimetria, largura à meia-altura, em suas componentes gaussiana e lorentziana; (vi) deslocamento atômico; (vii) microrugosidade e absorção. A estratégia de refinamento foi baseada em Paiva-Santos (2006), Gualtieri (inédito) e McCusker et al. (1999), sofrendo alterações em cada caso, para acomodar as diferenças estruturais entre as amostras. A determinação do alargamento instrumental dos picos foi feita pela análise de um padrão $\left(\mathrm{CeO}_{2}\right.$ tratado termicamente) com tamanho de cristalito homogêneo, isento de microdeformação e com baixa densidade de defeitos cristalinos. O refinamento dos dados pelo método de Rietveld foi realizado no software GSAS (General Structure Analysis System, Larson e Von Dreele, 2004) com a interface gráfica EXPGUI (Toby, 2001). A conversão dos difratogramas do formato *.RAW (Siemens) para *.GSA (GSAS) foi feito com o programa ConvX. 


\subsection{Química de rocha total e de minerais}

As análises químicas de rocha total de 24 amostras foram executadas no Instituto de Geociências da USP em amostras de metdolomito original $(n=6)$, metadolomito relacionado à talcificação $(n=16)$ e em tremolita mármore dolomítico no contato com o granito $(n=2)$. As análises foram feitas por fluorescência de raios $X$ em equipamento Philips Analytical PW 2400 em pastilhas fundidas e prensadas para os elementos maiores e menores $\left(\mathrm{SiO}_{2}, \mathrm{TiO}_{2}, \mathrm{Al}_{2} \mathrm{O}_{3}, \mathrm{Fe}_{2} \mathrm{O}_{3}\right.$ total, $\mathrm{MgO}, \mathrm{CaO}, \mathrm{MnO}, \mathrm{Na}_{2} \mathrm{O}, \mathrm{K}_{2} \mathrm{O}$ ) e por espectrometria de emissão óptica com plasma induzido acoplado (induced coupled plasma, ICP-AES ARL-3410) para os elementos-traço (Ba, Sr, V, Y, Zr, S). Determinações de teor de $\mathrm{CO}_{2}$ foram feitas por analisador elementar de carbono (LECO CHN 1000)

Os minerais analisados por microssonda eletrônica foram dolomita $(\mathrm{n}=11)$, calcita $(n=64)$, talco $(n=86)$, serpentina $(n=18)$, clorita $(n=13)$, tremolita $(n=30)$, diopsídio $(n=36$ ), considerando sempre as suas respectivas relações petrográficas. As análises foram feitas no Instituto de Geociências da USP em equipamento JEOL JXA SuperProbe 8600 com 5 espectrômetros, utilizando sistema de análise automatizada WDS 4.1 Termo-Noran e EDS acoplado. As condições de operação foram $15 \mathrm{kV}, 20,10$ $\pm 0,10 \mathrm{nA}$, diâmetro do feixe $5 \mu \mathrm{m}$ e $10 \mu \mathrm{m}$, com correções quantitativas através do programa PRZ Termo-Noran, com erro analítico estimado em $\pm 3 \%$. As estimativas geotermométricas foram baseadas na fração molar de $\mathrm{MgCO}_{3}$ em calcita coexistente com dolomita, segundo equação de Puhan (1995) $\left[\log \mathrm{X}_{\mathrm{Mg}}=-1414 / \mathrm{T}+0,4869\right]$.

\subsection{Análises de isótopos estáveis de carbono e oxigênio}

Dados de isótopos estáveis de carbono e oxigênio foram obtidos em 83 amostras de litotipos representativos, incluindo metadolomito original $(n=7)$, metadolomito relacionado à talcificação $(\mathrm{n}=59)$, metadolomito em contato com granito $(n=8)$, metadolomito em contato com diabásio $(n=5)$ e carbonatos supergênicos $(n=4)$; destas amostras, 45 são de dolomita, 37 de calcita e uma de aragonita. As análises isotópicas foram realizadas no Instituto de Geociências da USP em espectrômetros Europa modelo GEO 2020 e IRMS Delta Plus Advantage ThermoFinnigan. A extração das amostras foi feita a $25^{\circ} \mathrm{C}$ por reação off-line com ácido fosfórico $100 \%$ e a qualidade dos resultados controlada em relação ao padrão interno do laboratório e aos padrões internacionais 
IAEA-CO-1, IAEA-CO-8, NBS-18 e NBS-19. Para cada análise foram coletados no mínimo $10 \mathrm{mg}$ de rocha com por separação manual sob lupa binocular ou com microbroca de $1 \mathrm{~mm}$ de diâmetro, dos quais uma alíquota de $5 \mathrm{mg}$ foi analisada. As amostras de rocha total contendo dolomita e calcita foram analisadas pelo procedimento de dupla extração, com uma extração de $\mathrm{CO}_{2}$ após 1hora (calcita), seguida de uma descarga intermediária de $\mathrm{CO}_{2}$ após 24horas para garantir que a calcita tenha sido totalmente consumida, e uma segunda extração depois de 72horas (dolomita). Os dados isotópicos são apresentados nas notações $\delta^{13} \mathrm{C}_{\mathrm{PDB}}\left[\%\right.$ o] para carbono e $\delta^{18} \mathrm{O}_{\mathrm{SMOW}}[\%$ o] para oxigênio. A precisão analítica é de $0,2 \%$ para as razões isotópicas de carbono e de oxigênio.

O fracionamento isotópico por interação fluido-rocha foi calculado de modo similar ao proposto por Hecht et al. (1999) e Boulvais et al. (2006), considerando os seguintes parâmetros:

- sistema aberto, volatilização tipo Rayleigh;

- temperaturas varíaveis entre 150 e $450^{\circ} \mathrm{C}$;

- relações fluido-rocha variáveis (fluido:rocha $=0,01 ; 0,1 ; 0,5 ; 1 ; 5 ; 10 ; 50 ; 100$ );

- pressão parcial de espécies carbônicas $\left(\mathrm{X}_{\mathrm{C}}\right)$ 0,05 e 0,10;

- composição isotópica inicial da dolomita original $\delta^{13} \mathrm{C}_{\mathrm{PDB}}=2,4 \%$, $\delta^{18} \mathrm{O}_{\mathrm{SMOW}}=$ $26 \%$; a partir desta composição obtida em uma amostra, foi calculada a composição da calcita em equilíbrio a $400^{\circ} \mathrm{C}\left(\delta^{13} \mathrm{C}_{\mathrm{PDB}}=1,3 \%\right.$ o, $\delta^{18} \mathrm{O}_{\mathrm{SMOW}}=24,2 \%$ ) , usando os fatores de fracionamento de Sheppard e Schwarcz (1970);

- composição isotópica inicial atribuída ao fluido hidrotermal $\delta^{13} \mathrm{C}_{\mathrm{PDB}}=-5 \%$, $\delta^{18} \mathrm{O}_{\text {SMOW }}=3 \%$;

- fatores de fracionamento isotópico segundo O'Neil et al. (1969), Sheppard e Schwarcz (1970), Ohmoto e Rye (1979);

- razões fluido:rocha segundo equações de Taylor (1979).

\subsection{Microtermometria de inclusões fluidas}

As análises petrográficas e microtermométricas de inclusões fluidas foram feitas no Instituto de Geociências da USP, em inclusões em quartzo e calcita associados à 
talcificação. Foram confeccionadas 25 seções bipolidas para análise de inclusões fluidas. Foram analisadas inclusões primárias, contemporâneas à cristalização dos minerais hospedeiros, identificadas por critérios petrográficos (e.g., Roedder, 1984; Goldstein e Reynolds, 1994). As análises foram realizadas em equipamento Chaixmeca MTM85 acoplado a microscópio petrográfico Leitz. A platina utilizada foi calibrada utilizando-se os padrões MERCK Signotherm para baixas temperaturas e MERCK MSP para temperaturas elevadas.

As propriedades termodinâmicas dos fluidos aprisionados, incluindo densidade, salinidade e frações molares dos componentes foram calculadas utilizando-se as equações de Archer (1992) e de Zhang e Frantz (1987), referentes ao sistema $\mathrm{H}_{2} \mathrm{O}$ $\mathrm{NaCl}$, incluídas no programa BULK, pertencente ao pacote de programas "FLUIDS" de Bakker (2003). O cálculo das isócoras foi feito com base nas equações de Bodnar e Vityk (1994) e Knight e Bodnar (1989) presentes no Programa ISOC do mesmo pacote de programas de Bakker (2003). A análise de inclusões fluidas em carbonatos levou em consideração restrições devidas à facilidade de recristalização destes minerais e às interações entre fluido e mineral hospedeiro (e.g. Roedder, 1984; Goldstein, 2001).

Os dados disponíveis até o momento referem-se a inclusões em cristais de quartzo e calcita em talco xisto em zona de cisalhamento (PTI 02 AI, Mina Paranaense) e na auréola de contato com o Granito Cunhaporanga (PTI 43AC, PTI05bac). Na amostra PTI02AI, os dados microtermométricos foram obtidos em 144 inclusões fluidas primárias, dispostas em agrupamentos tridimensionais aleatórios, em três cristais de carbonato (Fragmentos 4B, 7A, 12), e em 56 inclusões aprisionadas posteriormente, alinhadas segundo plano de fratura cicatrizada, num quarto cristal de carbonato (fragmento $3 \mathrm{C}$ ). Trata-se nos dois casos de inclusões bifásicas aquosas, com pequena variação na proporção volumétrica da fase vapor. As inclusões analisadas nas amostras PTI43AC ( $\mathrm{n}=43$ inclusões) e PTI05bac ( $\mathrm{n}=65$ inclusões) são em sua maioria carbônicas e aquo-carbônicas. Estas análises ainda estão em andamento, e as interpretações são menos conclusivas que no caso da amostra PTI02AI. 


\section{Localização e vias de acesso}

A área de estudo se localiza a nordeste do Município de Ponta Grossa, Paraná, abrangendo as localidades de Itaiacoca, Socavão e Abapã. O trajeto de São Paulo a Ponta Grosa pode ser feito pela Rodovia Castelo Branco até Sorocaba, depois seguindo em direção a Itapeva, Itararé e Castro (Figura 1). Outra possibilidade é seguir pela Rodovia Régis Bitencourt até Curitiba e de lá seguir até Ponta Grossa. O acesso aos afloramento estudados pode ser feito a partir de Ponta Grossa pela Rodovia dos Minérios e por estradas vicinais.

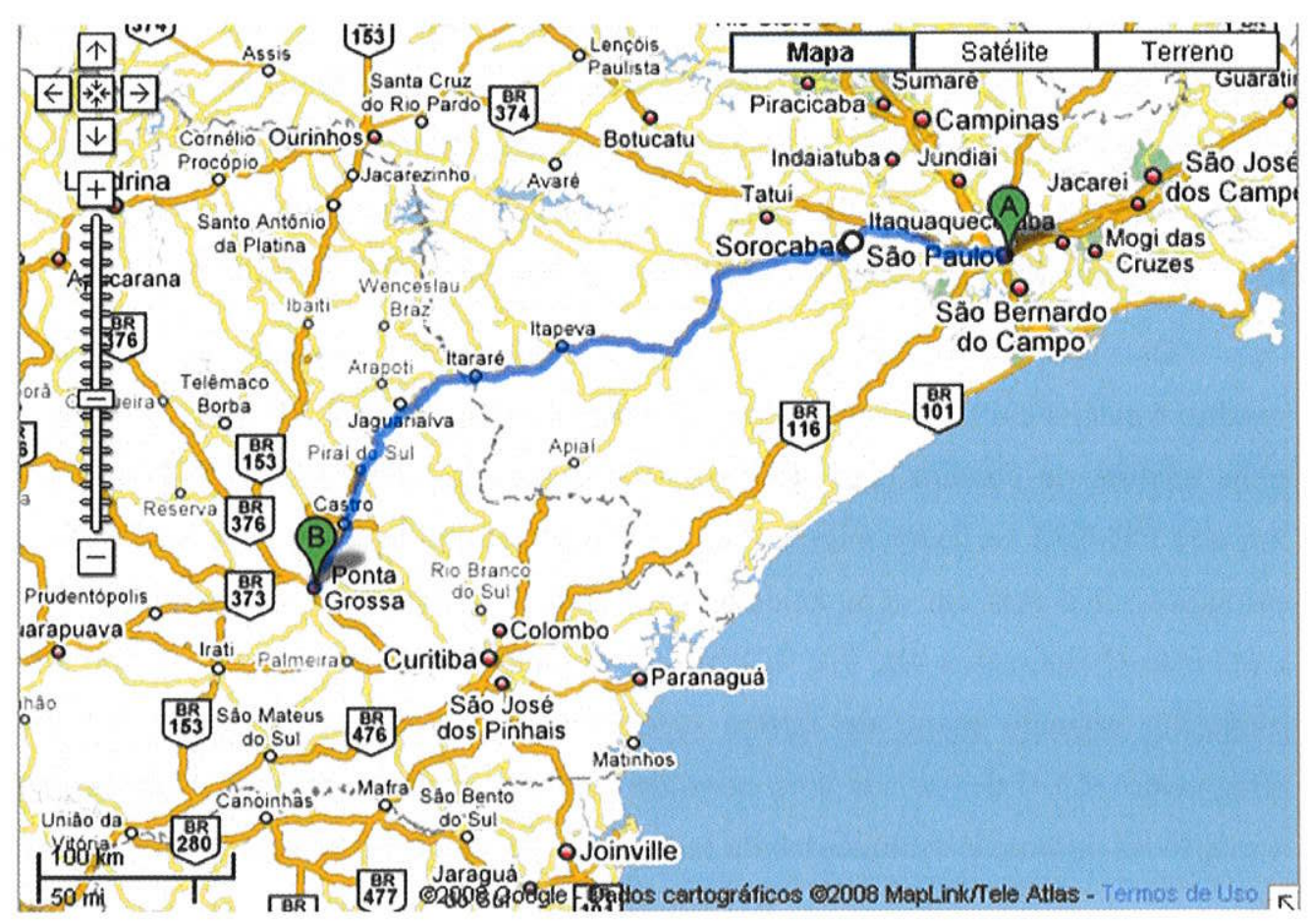

Figura 1. Mapa de localização e acesso à área de estudo (fonte www.googlemaps.com). 


\section{Geologia regional}

A área estudada localiza-se numa região onde afloram rochas metamórficas e ígneas (Figura 2) meso- a neoproterozóicas da Faixa de Dobramentos Ribeira (Almeida et al., 1973; Hasui et al., 1975), rochas sedimentares paleozóicas da Bacia do Paraná e diques de diabásio mesozóicos do Arco de Ponta Grossa (e.g. Almeida, 1983; Renne et al., 1996). As rochas metamórficas supracrustrais do Paraná e do sul de São Paulo foram inicialmente denominadas de Série Açunguí (Derby, 1878; Oliveira, 1916, apud Campanha e Sadowski, 1999).

A parte meridional do Cinturão Ribeira, composta predominantemente por rochas metamórficas supracrustais de baixo a médio grau, foi denominada Campanha e Sadowski (1999) de Domínio Apiaí, correspondendo ao antigo Grupo Açunguí. Os autores propõem um modelo de evolução geológica baseado na revisão de dados geocronológicos e tectônicos, e consideram que sedimentação e vulcanismo ocorreram no Paleo- e Mesoproterozóico, em bacias nas bordas do Oceano Adamastor, entre os paleocontinentes Paraná, a norte, e Luís Alves, a sul. No Neoproterozóico, o Domínio Apiaí teria se comportado como uma única massa continental, intrudida por rochas básicas entre 1,1 e $0,85 \mathrm{Ga}$. Um arco magmático cordilheirano teria se instalado na região entre 0,7 e $0,6 \mathrm{Ga}$, causando metamorfismo, migmatização e granitogênese cálcio-alcalina. Após o fechamento do oceano, entre 0,6 e $0,45 \mathrm{Ga}$ se instalaram zonas de cisalhamento transcorrentes dextrais relacionadas à colisão oblíqua e ao escape tectônico. Bacias tipo pull-apart se abriram e foram preenchidas por sequências molássicas. Finalmente, a região foi intrudida por granitóides pós-orogênicos, se estabilizou e passou a sofrer resfriamento regional. 


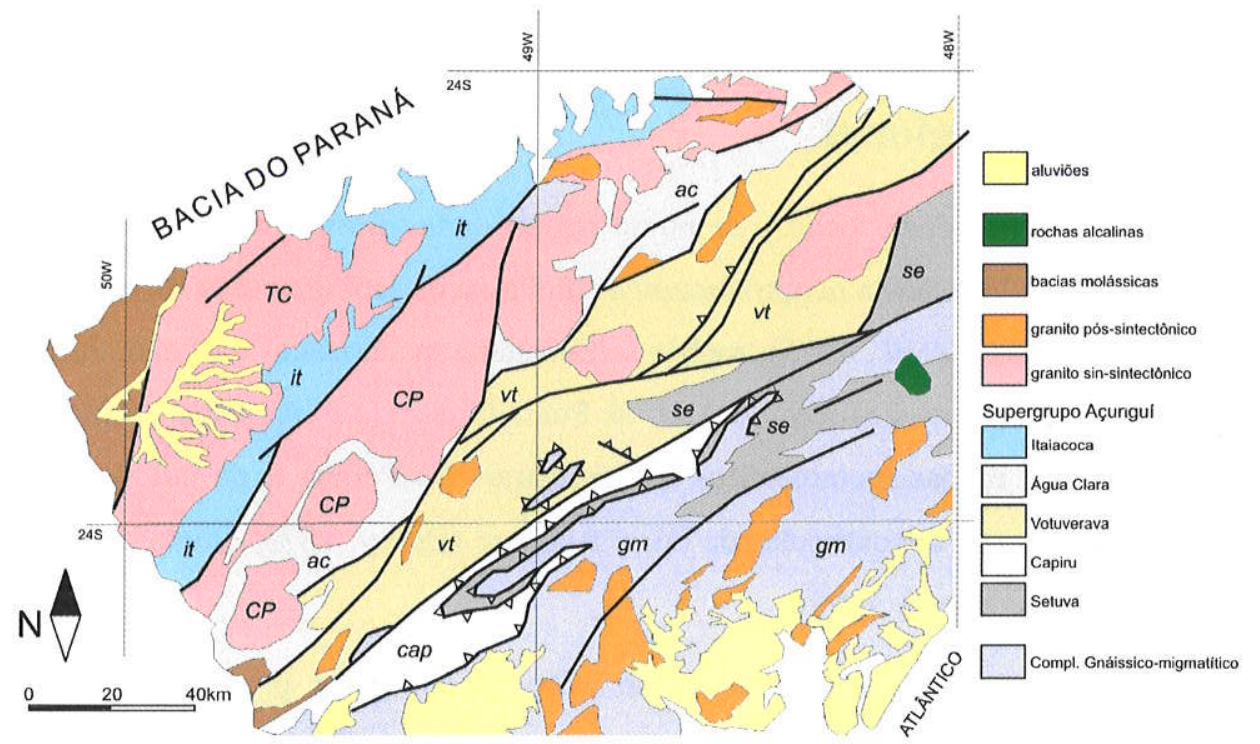

Figura 2. Mapa geológico regional, simplificado de Campanha e Sadowski (1999). Abreviações: $g m=$ Complexo Gnáissico-Migmatítico; $c a p=$ Formação Capiru; $v t=$ Grupo Votuverava; $a c=$ Formação Água Clara; $i t=$ Grupo Itaiacoca; $T C=$ Complexo Granítico Três Córregos; $\mathrm{CP}=$ Complexo Granítico Cunhaporanga.

As sequências proterozóicas do leste paranaense contêm expressivos pacotes de rochas metacarbonáticas, que são predominantes no Grupo Itaiacoca, na Formação Água Clara, na Formação Capiru e em parte do Grupo Votuverava. De todos estes pacotes metacarbonáticos, o mais semelhante com o Grupo Itaiacoca é a Formação Capiru (Marini et al., 1967; Fiori, 1990, 1992) localizada nas proximidades da região metropolitana de Curitiba. Ambos apresentam composição dolomítica e correspondem a sequências plataformais rasas (Campanha e Sadowski, 1999), dada a associação de metadolomitos com estromatólitos e oólitos com pacotes terrígenos compostos por filitos e quarzitos. As similaridades litológicas levaram autores como Almeida (1956) e Bigarella e Salamuni (1956) a correlacionar estas duas unidades litoestratigráficas. A Formação Capiru foi afetada por falhas de cavalgamento (e.g. Fiori, 1992) que a colocaram em situação alóctone sobre rochas arqueanas do Complexo Gnáissico Migmatítico (Campanha e Sadowski, 1999), também denominado de Complexo Atuba (Siga Jr. et al., 2003). No modelo de Campanha e Sadowski (1999), o Grupo Itaicoca representaria as fácies proximais em plataforma rasa, numa margem continental passiva na borda do paleocontinente Paraná, enquanto que a Formação Capiru ocuparia uma 
posição equivalente, na borda do Cráton de Luís Alves, ou Maciço de Joinville. As demais formações metacarbonáticas do leste paranaense, pertencentes às unidades Água Clara e Votuverava, são predominantemente calcíticas e mais intensamente deformadas.

O último grande evento tectônico ocorrido na região foi o vulcanismo basáltico toleí́tico Cretáceo associado ao rompimento de Gondwana e à abertura do Oceano Atlântico Sul, um processo iniciado a cerca de 135 Ma (e.g. Turner et al., 1994; Picirillo e Melfi, 1998). A manifestação deste vulcanismo na região é a presença de numerosos diques de diabásio de orientação geral N60W, subverticais, que representam os dutos de alimentação dos derrames basálticos continentais da Formação Serra Geral. O enxame de diques de diabásio define a abrangência do Arco de Ponta Grossa, uma estrutura regional de soerguimento que foi o principal foco do magmatismo basáltico na região durante o Cretáceo.

\subsection{Grupo Itaiacoca}

O Grupo Itaiacoca é uma faixa de rochas metassedimentares e metavulcânicas de baixo grau metamórfico alongada na direção geral N40E, que se estende desde a região de Itaiacoca (PR) até Itapeva (SP). O Grupo Itaiacoca situa-se entre os batólitos graníticos neoproterozóicos Cunhaporanga e Três Córregos. Considerado inicialmente como parte do Grupo Açunguí (e.g. Bigarella, 1947), recebeu posteriormente as denominações de Formação Itaiacoca (Almeida, 1956; Soares, 1987; Soares et al., 1987), Grupo Itaiacoca (IPT, 1985) e Faixa Itaiacoca (Reis Neto, 1994). A região foi objeto de mapeamento geológico em escala 1:150.000 realizado pela Comissão da Carta Geológica do Paraná (Fuck, 1967), em escala 1:100.000 pela CPRM (1977), em escala 1:150.000 por Guimarães (2000), e em escala 1:25.000 por alunos do curso de Geologia da USP, em 1997 (Prazeres Filho et al., 1998). Mapas geológicos de detalhe das principais jazidas e uma avaliação abrangente do distrito mineiro do talco no Paraná são apresentados por DNPM-Mineropar (1999).

O Grupo Itaiacoca contém estromatólitos Conophyton (Sallun Filho e Fairchild, 2004; Sallun Filho et al., 2005), que sugerem deposição em águas abaixo da zona de ação das ondas. Estromatólitos do mesmo tipo foram descritos no Canadá, onde a profundidade estimada para sua sedimentação foi entre 10 e $100 \mathrm{~m}$. A presença destes 
estromatólitos seria indicativa de sedimentação entre 850 e $1.700 \mathrm{Ma}$, não sendo, portanto, um critério geocronológico decisivo.

Siga Jr. et al. (2003) consideram que o Grupo Itaiacoca se formou no Neoproterozóico, com base em idades U-Pb em cristais de zircão das metavulcânicas $(628 \pm 18 \mathrm{Ma}$ e $636 \pm 30 \mathrm{Ma})$, interpretadas como idade de cristalização. Outra população de cristais de zircão forneceu idades de 2480 e $1990 \mathrm{Ma}$, intepretadas como idade do material detrítico oriundo de fontes paleoproterozóicas. Estas idades divergem das obtidas por Reis Neto (1994), que propõe o intervalo entre 1250 e 1080 Ma para deposição do Grupo Itaiacoca.

As relações de contato do Grupo Itaiacoca com os batólitos graníticos Cunhaporanga e Três Córregos (Figura 3) são de natureza distinta. O contato com o Complexo Granítico Cunhaporanga com a borda NW do Grupo Itaiacoca é intrusivo, marcado por auréola de metamorfismo de contato, enquanto que o contato com o Complexo Granítico Três Córregos é tectônico, marcado pela Zona de Cisalhamento Itapirapuã, de direção predominantemente N40E (CPRM, 1977). Segundo Prazeres Filho (2000) e Prazeres Filho et al. (2003), os Complexos Graníticos Cunhaporanga e Três Córregos contêm fácies graníticas do tipo I, típicos de margem continental ativa, com idades entre 630 e $625 \mathrm{Ma}$, e granitos tardios peraluminosos enriquecidos em potássio, sin- a tardicolisionais com idades entre 620 e $590 \mathrm{Ma}$. O magmatismo granítico na região extendeu-se até $560 \mathrm{Ma}$, com stocks anorogênicos pós-colisionais de pequeno porte. Juntamente com o Complexo Granítico Três Córregos, a sudeste da Zona de Cisalhamento Itapirapuã afloram rochas supracrustais metamorfisadas em grau baixo a médio, localmente representadas pela Formação Água Clara (Marini et al., 1967; Fassbinder, 1996). 


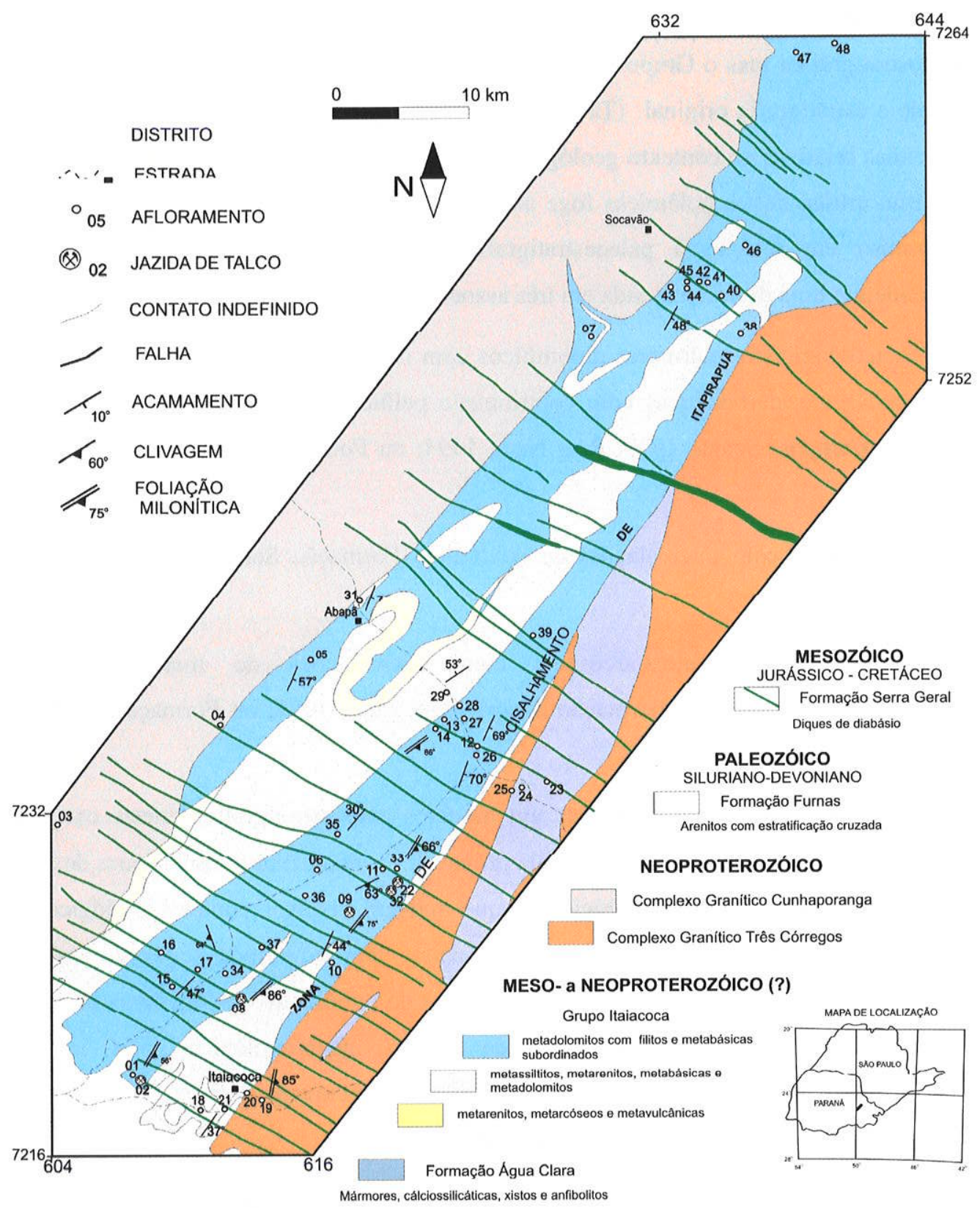

Figura 3. Mapa geológico do Grupo Itaiacoca entre Itaiacoca e Socavão, Estado do Paraná (modificado de CPRM, 1977). 
Desde a década de 1930 foram feitas diversas tentivas de divisão liteostratigráfica mas o Grupo Itaiacoca continua sendo motivo de debate quanto à sua idade e estratigrafia original (Tabela 1). A seguir serão abordadas de modo resumido questões relativas ao contexto geológico, à estratigrafia e as idades desta unidade; uma revisão crítica destas polêmicas foge ao objetivo deste trabalho. Apesar de não haver consenso em relação à paleoestratigrafia do Grupo Itaiacoca, diversos autores consideram uma divisão baseada em três associações litológicas principais:

- metadolomitos e mármores dolomíticos com intercalações de metabasitos, filitos e rochas metacarbonáticas com contribuição pelítica e psamítica (Formação Bairro dos Campos, Souza, 1990; Reis Neto, 1994; ou Formação Tanque Grande, Lima, 1993b);

- metapelitos com intercalações de quartzitos (Formação Serra dos Macacos, Reis Neto, 1994);

- metanarenitos e meta-arcóseos, com intercalações de metavulcânicas e metavulcanoclásticas (Formação Abapã, Reis Neto, 1994; ou Formação Bairro da Estiva, Souza, 1990).

A dificuldade em se propor um modelos paleoestratigráficos neste caso está relacionada ao fatiamento tectônico pelas zonas de cisalhamento transcorrentes dextrais, que afetam todos os tipos litológicos e que marcam diversos contatos litológicos no interior do Grupo Itaiacoca. Estes falhamentos têm amplitude regional, podendo alcançar rejeitos estimados da ordem de dezenas de quilômetros. Além disto, as rochas metacarbonáticas não são passíveis de datação geocronológica pelos métodos radiométrico convencionais, tendo sido datadas indiretamente através da datação das rochas metavulcânicas e metabásicas a elas associadas.

O Grupo Itaiacoca foi afetado por quatro episódios metamórficos. A seguir são resumidas as feições metamórficas, com ênfase naquelas presentes nos metadolomitos:

- metamorfismo regional (Ciclo Brasiliano, Neoproterozóico): atingiu a fácies xisto verde, zona da clorita, localmente zona da biotita, formando metadolomitos cinza, filitos e anfibolitos, cujas estruturas primárias sedimentares e vulcânicas encontramse em parte preservadas (Reis Neto, 1994; Prazeres $\mathrm{F}^{\circ}$ et al., 1998; Siga Jr. et al., 2003; Szabó et al., 2006). Nas rochas metapelíticas e metavulcânicas, desenvolveuse uma foliação $S_{1}$ subparalela ao acamamento $\left(S_{0}\right)$, foliação esta que é 
praticamente imperceptível nos metadolomitos, a não ser em rochas metacarbonáticas impuras. A seguir, formaram-se dobras abertas assimétricas $D_{2}$, com plano axial subvertical, às quais se associa foliação plano-axial $S_{2}$. Houve formação de muscovita e clorita nas foliações $S_{1}$ e $S_{2}$ em metapelitos e filitos carbonáticos. Nos filitos, filitos carbonáticos e metavulcânicas a foliação $\mathrm{S}_{2}$ ocorre como clivagem de crenulação, enquanto que nos meta-arenitos e metadolomitos desenvolveu-se uma clivagem espaçada. Para alguns autores (Soares, 1987; Lima, 1993b, 1997; DNPM-MINEROPAR, 1999), a foliação $S_{1}$ teria se desenvolvido no decorrer do cisalhamento associado a processos de cavalgamento, entretanto, não foram observadas feições de cisalhamento de baixo ângulo na porção meridional do Grupo Itaiacoca no âmbito do presente trabalho;

- metamorfismo dinâmico e hidrotermal (Ciclo Brasiliano, Neoproterozóico): este episódio transformou os metadolomitos em calcita talco xistos ao longo da Zona de Cisalhamento Itapirapuã e suas ramificações, que definem o contato tectônico do Grupo Itaiacoca com o Complexo Granítico Três Córregos (630 Ma, Prazeres $\mathrm{F}^{\mathrm{Q}}$ et $a l ., 2003$ ) e com a Formação Água Clara (1.500 Ma, Fassbinder, 1996; Weber et al., 2004). A intensa percolação de fluidos ricos em sílica nas zonas de cisalhamento transcorrente foi responsável pela formação das principais jazidas de talco na porção meridional do Grupo Itaiacoca (e.g. Szabó et al., 2004);

- metamorfismo termal I (Ciclo Brasiliano, Neoproterozbico): ocorreu no contato intrusivo do Complexo Granítico Cunhaporanga (590 Ma, Prazeres $\mathrm{F}^{0}, 2000$; Prazeres $\mathrm{F}^{\mathrm{Q}}$ et al. 2003) na borda NW do Grupo Itaiacoca, formando mármores brancos com bolsões concêntricos contendo paragêneses de mais alto grau no núcleo e retrometamórficas nas bordas (forsterita \pm diopsídio \pm tremolita \pm quartzo \pm calcita), além de xistos com granada \pm sillimanita \pm andalusita. A abrangência espacial deste evento restringe-se à zona de contato intrusivo com o Complexo Granítico Cunhaporanga, sendo pouco penetrativa no Grupo Itaiacoca;

- metamorfismo termal II (ruptura de Gondwana, Cretáceo): concentrando-se ao longo do Arco de Ponta Grossa, formando mármores brancos (brucita \pm serpentina \pm calcita) restritos a espessuara de poucos centímetros nas zonas de contato intrusivo com diques de diabásio ( 135 Ma, Renne et al., 1996). 
Tabela 1. Propostas de empilhamento estratigráfico para o Grupo Itaiacoca (modificada DNPM-Mineropar, 1999).

\begin{tabular}{|c|c|c|c|c|c|c|c|}
\hline IPT, 1985 & Trein et al., 1985 & Soares, 1987 & Mineropar, 1988 & Souza, 1990 & Reis Neto, 1994 & $\begin{array}{l}\text { Campanha e } \\
\text { Sadowski, } 1999\end{array}$ & Siga Jr. et al., 2003 \\
\hline $\begin{array}{l}\text { Folhas Araçaiba e } \\
\text { Barra do Cabpés }\end{array}$ & $\begin{array}{l}\text { Abapã - Herval do } \\
\text { Xaxim }\end{array}$ & regional & Itaiacoca - Socavão & $\begin{array}{l}\text { Folhas Barra do } \\
\text { Chapéu e Ouro } \\
\text { Verde }\end{array}$ & Itaiacoca - Socavāo & regional & \\
\hline $\begin{array}{l}\text { Grupo Itaiacoca } \\
\text { sequências }\end{array}$ & $\begin{array}{l}\text { Fm. Itaiacoca } \\
\text { sequências }\end{array}$ & $\begin{array}{l}\text { Complexo Itaiacoca } \\
\text { associações }\end{array}$ & $\begin{array}{l}\text { Grupo Itaiacoca } \\
\text { formações }\end{array}$ & $\begin{array}{l}\text { Grupo Itaiacoca } \\
\text { formaçóes }\end{array}$ & $\begin{array}{l}\text { Grupo Itaiacoca } \\
\text { formações }\end{array}$ & $\begin{array}{l}\text { Grupo Itaiacoca } \\
\text { sequências }\end{array}$ & $\begin{array}{l}\text { Grupo Itaiacoca } \\
\text { sequências }\end{array}$ \\
\hline $\begin{array}{l}\text { superior: mármores e } \\
\text { quartzitos } \\
\text { intermediária: } \\
\text { quartzitos e filitos } \\
\text { basal: filitos, } \\
\text { quartzitos, dolomitos }\end{array}$ & $\begin{array}{l}\text { carbonática: } \\
\text { mármores e } \\
\text { quartzitos } \\
\text { Abapã: } \\
\text { metavulcânicas, } \\
\text { metarcóseos }\end{array}$ & 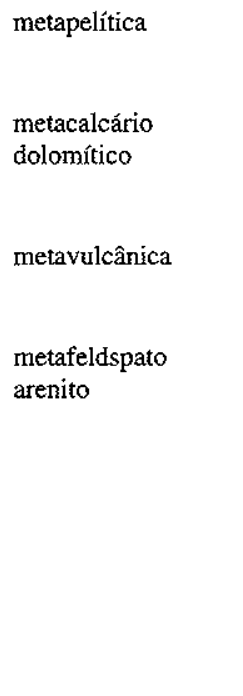 & $\begin{array}{l}\text { Bairro dos Campos: } \\
\text { metadolomitos e } \\
\text { filitos } \\
\text { Água Nova: } \\
\text { metadolomitos, } \\
\text { filitos, metabásicas, } \\
\text { quartzitos } \\
\text { Abapã : } \\
\text { metavulcânicas, } \\
\text { piroclásticas, } \\
\text { metarcóseos }\end{array}$ & $\begin{array}{l}\text { Bairro dos Campos: } \\
\text { metacarbonáticas, } \\
\text { carbonática arenosa, } \\
\text { carbonática argilosa } \\
\text { Serra dos Macacos: } \\
\text { metapelítica arenosa, } \\
\text { metapelítica } \\
\text { carbonática, } \\
\text { metabasitos } \\
\text { Bairro das Almas: } \\
\text { metapelítica } \\
\text { carbonática } \\
\text { Bairro da Estiva: } \\
\text { metapsamítica } \\
\text { arcoseana }\end{array}$ & $\begin{array}{l}\text { Serra dos Macacos: } \\
\text { metarenitos, } \\
\text { metassitititos } \\
\text { Água Clara: } \\
\text { mármores, } \\
\text { cálciosilicáticas, } \\
\text { xistos, anfibolitos } \\
\\
\text { Abapā: metarcóseos, } \\
\text { piroclásticas, } \\
\text { metavulcânicas }\end{array}$ & $\begin{array}{l}\text { Bairro dos Campos: } \\
\text { metadolomitos, } \\
\text { metabásicas } \\
\text { Serra dos Macacos: } \\
\text { ortiquartzitos, } \\
\text { metaconglomerados } \\
\text { Água Nova: } \\
\text { metassiltitos, } \\
\text { metarnitmitos, filitos } \\
\text { Bairro da Estiva: } \\
\text { metarenitos } \\
\text { arcoseanos, filitos, } \\
\text { paraconglomerados, } \\
\text { metabásicas }\end{array}$ & $\begin{array}{l}\text { superior: } \\
\text { ortoquartzitos, } \\
\text { metarenitos finos e } \\
\text { médios, filitos, filitos } \\
\text { grafitosos, } \\
\text { metapsamitos } \\
\text { intermediária: } \\
\text { márm. dolomíticos, } \\
\text { márm. impuros, } \\
\text { filitos com } \\
\text { carbonatos } \\
\text { basal: } \\
\text { metarenitos } \\
\text { arcoseanos, } \\
\text { metavulcânicas, } \\
\text { metavulcanoclásticas }\end{array}$ \\
\hline
\end{tabular}




\section{Talco: geologia econômica, estatísticas e usos industriais}

O talco tem sido usado desde os primórdios da civilização, principalmente na forma de esteatito (pedra-sabão). A facilidade para a produção de peças entalhadas permitiu amplo uso na produção de vasilhames, adornos e outros utensílios desde período Paleolítico, com registros de uso desde cerca de 7500 anos atrás. Utensílios de esteatito têm sido encontrados em sítios arqueológicos de diversos povos, como os Vikings na Escandinávia, os Harappan na Índia, os Inuit no Ártico, além de povos na América do Norte e Central, África (Rapp, 2002). Com o surgimentos das primeiras fundições de cobre e bronze, o estaetito passou a ser esculpido para a produção de moldes. $\mathrm{O}$ talco está presente também nos dois tratados que inauguraram as ciências da Terra, que são Peri Lithon do grego Teofrasto ( $372-287$ a.C.) e Naturalis Historia do italiano Plínio, o velho (23-79 a.C.).

$\mathrm{O}$ talco é um filossilicato hidratado de magnésio $\left(\mathrm{Mg}_{3} \mathrm{Si}_{4} \mathrm{O}_{10}(\mathrm{OH})_{2}\right)$ que tem ampla gama de aplicações industriais. A maior parte da produção de talco destina-se às indústrias de cerâmica, tintas e papéis, seguidas por plásticos, borrachas, defensivos agrícolas, produtos farmacêuticos, cosméticos e veterinários, sabões e velas, têxtil e alimentícia, onde o talco normalmente é usado como carga mineral.

Os depósitos de talco se formam a partir de rochas ultramáficas ou de rochas dolomíticas, em ambos os casos pela atividade de soluções hidrotermais. Em complexos ultramáficos, os silicatos magnesianos, principalmente a olivina, podem ser alterados metassomaticamente e formar esteatitos, que podem conter, além do talco, outros minerais como clorita, serpentina e anfibólios. Em rochas dolomíticas, a formação de talco a partir de dolomita se dá pela atividade de fluidos capazes de remover $\mathrm{Ca}^{\mathrm{e}} \mathrm{CO}_{2}$, e concomitantemente promover a combinação de sílica e água com o magnésio livre.

Os dados mais recentes sobre as reservas, a produção e o consumo de talco no Brasil são o Sumário Mineral 2007 e o Anuário Mineral 2006, ambas publicações do DNPM (Departamento Nacional de Produção Mineral) disponíveis no site www.dnpm.gov.br. Uma revisão atualizada do mercado internacional e norte-americano pode ser encontrada no Mineral Commodity Summary 2007 do USGS (United States Geological Survey, www.usgs.gov). O Brasil está entre os seis maiores produtores mundiais de talco, juntamente com a China, Estados Unidos, Índia, Japão e Coréia. 
A comparação entre dados estatísticos sobre o talco apresentados por diversas fontes revela significativas discrepâncias (Tabela 2). Uma possível fonte de erros é a "... frequente troca de terminologia associada ao segmento dos minerais industrais ..." (DNPM, 2007). Os dados sobre o talco são, em alguns casos, apresentados em conjunto e de modo indistinto com os dados estatísticos sobre a pirofilita $\left(\mathrm{Al}_{2} \mathrm{Si}_{4} \mathrm{O}_{10}(\mathrm{OH})_{2}\right)$, seu análogo aluminoso, ou ainda dados conjuntos de talco, pirofilita, filito e demais cargas minerais somadas de modo indistinto. Para complicar ainda mais, a indústria utiliza os termos talco e pirofilita também para designar as rochas metamórficas que contêm estes minerais (esteatito, saponito, pedra"sabão, agalmatolito) e que podem conter outros minerais. Apesar de alguns usos comuns, talco e pirofilita em geral têm aplicações distintas, como na indústria cerâmica, onde o talco é uma fonte de magnésio para controle da expansão térmica, e a pirofilita é uma fonte de alumínio e favorece a refratariedade. Conforme a aplicação, o talco e a pirofilita concorrem com outras matérias-primas como argilas especiais, filitos, caulins, calcários e dolomitos.

Tabela 2. Estimativas da produção de talco em toneladas, ano-base 2005, segundo DNPM (2007) e USGS (2007),

\begin{tabular}{lrr}
\hline & DNPM (2007) & USGS (2007) \\
\hline China & 3.000 .000 & 3.000 .000 \\
República da Coréia & 900.000 & 900.000 \\
Estados Unidos & 856.000 & 856.000 \\
Japão & 431.000 & 630.000 \\
Índia & 630.000 & 542.000 \\
Brasil & 413.000 & 607.000 \\
outros países & 1.280 .000 & 1.280 .000 \\
total & 7.510 .000 & 7.815 .000 \\
\hline
\end{tabular}

O Paraná contém as maiores reservas medidas de talco do Brasil, atingindo $60 \%$ das reservas nacionais que ultrapassaram as 115.000 .000 toneladas no ano-base 2005 (Tabela 3), em dados (DNPM, 2006a). O restante das reservas se concentra nos Estados de São Paulo e Bahia, com cerca de $16 \%$ cada, seguidos por Minas Gerais e Rio Grande 
do Sul, com cerca de $4 \%$ cada (Figura 4). Os dados da produção nacional por Estados (DNPM, 2006b) indicam que o Paraná detém a maior produção bruta, enquanto que a Bahia detém a maior produção de talco beneficiado, o qual alcança um valor por tonelada cerca de seis vezes superior ao do Paraná (Tabela 4, Figura 5). Quanto ao talco bruto, o produto paranaese teve um valor médio de $R \$ 34 /$ tonelada, enquanto que o produzido na Bahia atingiu $\mathrm{R} \$ 1053$ tonelada. Já o talco beneficiado atingiu PR R\$65/tonelada no Paraná e R \$788/tonelada na Bahia. Percebe-se aqui uma inconsistência, pois os dados oficiais registram que na Bahia o talco bruto teve valor unitário mais elevado que talco beneficiado. Isto pode se dever à coleta de dados, onde um lote comercializado a preços extremamente altos ou baixos pode afetar as estatísticas. O preço de mercado do talco é altamente variável, em função do seu grau de pureza e de sua homogeneidade, que são os principais fatores determinantes do tipo de uso industrial.

Tabela 3. Reservas medida de talco no Brasil em toneladas, ano-base 2005 (DNPM, 2006a).

\begin{tabular}{lrr}
\hline & reserva medida (t) & participação nacional (\%) \\
\hline Paraná & 68.232 .405 & 59,1 \\
Sāo Paulo & 18.974 .083 & 16,4 \\
Bahia & 18.533 .671 & 16,1 \\
Minas Gerais & 5.176 .420 & 4,5 \\
Rio Grande do Sul & 4.535 .459 & 3,9 \\
Goís & 38.572 & 0,03 \\
total & 115.490 .610 & 100 \\
\hline
\end{tabular}




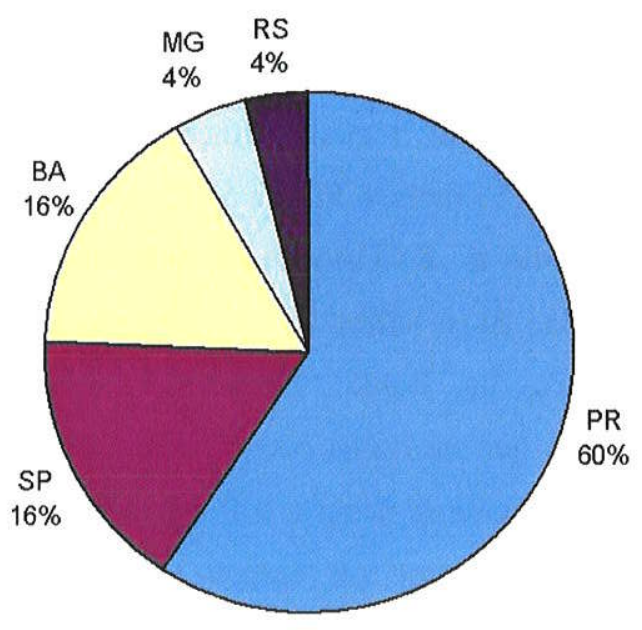

a.

Figura 4. Participação dos Estados nas estatísticas brasileiras sobre o talco ano-base 2005 (DNPM, 2006a). (a) Reservas nacionais (total 115,5 milhões de toneladas); (b) valor da produção (total R $\$ 56$ milhões)

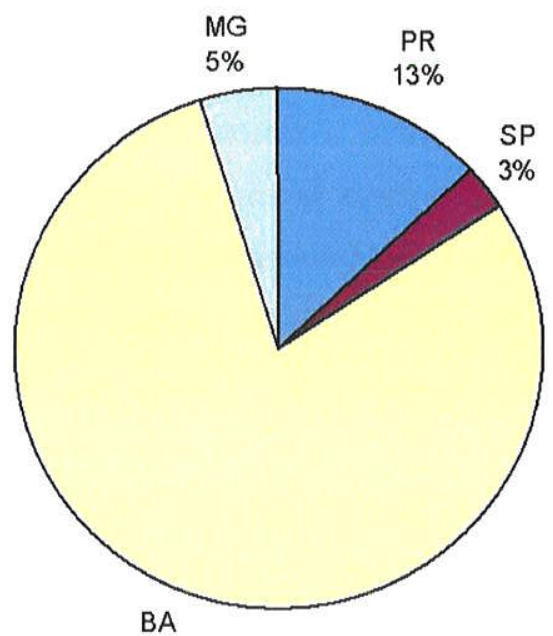

b.
$79 \%$

Tabela 4. Estimativas da produção e valores de talco no Brasil, ano-base 2005 (DNPM, 2006a).

\begin{tabular}{|c|c|c|c|c|c|c|c|}
\hline & \multicolumn{3}{|c|}{ produção bruta } & \multicolumn{3}{|c|}{ produção beneficiada } & \multirow[b]{2}{*}{ valor total } \\
\hline & $\begin{array}{r}\text { quantidade } \\
(\mathrm{t})\end{array}$ & valor $(\mathrm{R} \$)$ & $\begin{array}{r}\text { valor unitário } \\
(\mathrm{R} \$ / \mathrm{t})\end{array}$ & quantidade $(\mathrm{t})$ & valor $(\mathrm{R} \$)$ & $\begin{array}{r}\text { valor unitário } \\
(\mathrm{R} \$ / \mathrm{t})\end{array}$ & \\
\hline PR & 139.871 & 4.751 .927 & 33,97 & 40.309 & 2.604 .428 & 64,61 & 7.356 .355 \\
\hline SP & 32.476 & 661.835 & 20,38 & 23.915 & 853.804 & 35,70 & 1.515 .639 \\
\hline $\mathrm{BA}$ & 31 & 32.648 & 1053,16 & 56.239 & 44.344 .644 & 788,50 & 44.377 .929 \\
\hline MG & 13.750 & 1.793 .468 & 130,43 & 2.887 & 923.633 & 319,93 & 2.717 .101 \\
\hline RS & 1.800 & 36.000 & 20,00 & -- & -- & -- & 36.000 \\
\hline total & 187.928 & 7.275 .878 & 38,72 & 123.350 & 48.726 .509 & 395,03 & 56.002 .387 \\
\hline
\end{tabular}




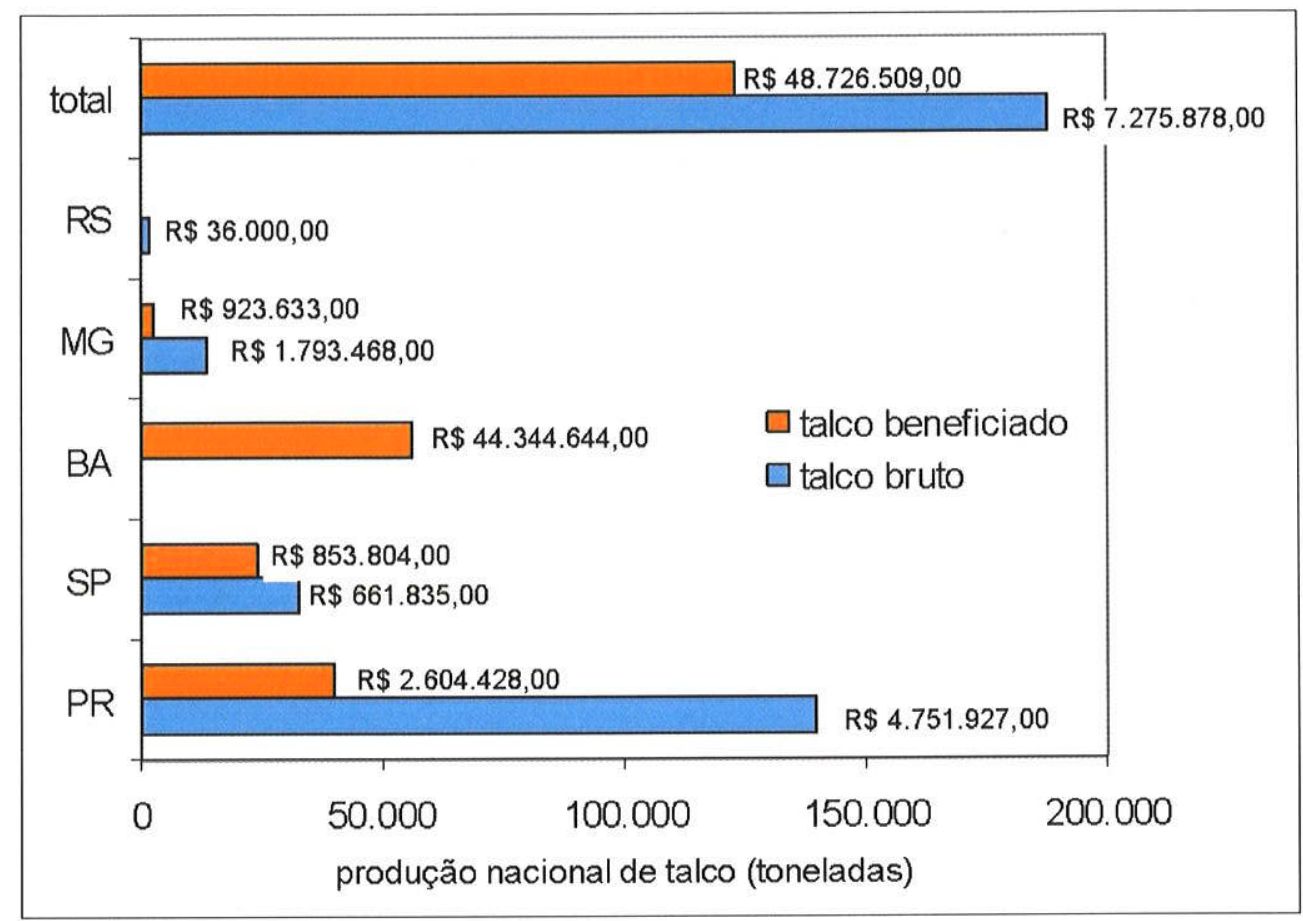

Figura 5. Produção de talco e respectivos valores no Brasil, ano-base 2005 (DNPM, 2006a). 


\section{Aspectos patológicos relacionados a poeiras minerais}

O talco pode estar relacionado à origem de doenças devido a características intrínsecas como estabilidade química e tamanho de partícula, e, indiretamente, devido à presença de contaminantes minerais, em particular os minerais de asbestos, que comumente estão presentes em seus minérios. A exposição prolongada a ambientes saturados em poeiras minerais causa doenças pulmonares graves, algumas delas irreversíveis (Richards, 2003). O risco de doenças aumenta com o tempo de residência das partículas no pulmão, que é função da biodurabilidade, que é a resistência à dissolução química no corpo, e da biopersistência, que é a resistência total de uma partícula frente aos mecanismos de limpeza do sistema respiratório (Jurinski e Rimstidt, 2001). Algumas destas patologias recebem nomes referentes aos minerais causadores, como silicose, asbestose e talcose.

$\mathrm{O}$ uso de talco em cosméticos vem sofrendo restrições, tanto pela frequente associação entre talco e minerais de asbestos (e.g. tremolita, serpentina) nas assembléias minerais dos minérios, como pela própria biopersistência do talco. A talcose é uma pneumoconiose benigna caracterizada pela formação de nódulos fibrosos nos pulmões e causada pela inalação prolongada e excessiva de talco. Nas condições de pH do pulmão humano, uma partícula de talco com $1 \mu \mathrm{m}$ levaria aproximadamente 8 anos para ser destruída. $\mathrm{O}$ talco é dissolvido mais rapidamente que o quartzo, mas mais lentamente que crisotila e olivina (Jurinski e Rimstidt, 2001).

As características geológicas dos ambientes de formação das jazidas de talco fazem com que a contaminação dos minérios por asbestos de anfibólio (tremolita) ou serpentina (crisotila) seja relativamente frequente, ainda que em muitos casos os níveis de contaminação sejam baixos (Szabó et al., 2000). Van Gosen et al. (2004) observa uma variação do tipo de asbestos em função do ambiente de formação das jazidas, onde o talco formado a temperaturas relativamente baixas $\left(<400^{\circ} \mathrm{C}\right)$ poderia ter contaminação apenas de crisotila, enquanto que o formado a temperaturas mais elevadas num contexto de metamorfismo de contato poderiam apresentar asbestos de anfibólio. Entretanto, este critério não é válido para o Grupo Itaiacoca, pois lá a tremolita fibrosa ocorre tanto no contexto de metamorfimo de contato como em zonas de cisalhamento. Isto mostra que a generalização de critérios pode ser perigosa e que a avaliação de risco deve ser feita 
caso a caso. O cuidado na seleção de matérias-primas nem sempre é levado em consideração na mineração, beneficiamento e uso final de talco.

Tanto os asbestos de anfibólio como de crisotila devem ser tratados como potencialmente carcinogênicos e causadores de doenças pulmonares graves, ainda que $o$ anfibólio seja mais perigoso devido à sua maior biopersistência (McDonald e McDonald, 1997). Estatísticas internacionais comprovam a relação direta entre inalação de asbestos e o desenvolvimento de doenças pulmonares graves (e.g. Selikoff e Lee, 1978; Skinner et al., 1988; Virta, 1998; Scliar, 1998; Virta et al., 2004), o que levou vários países a proibir o seu uso. O Brasil baniu o uso de asbestos de anfibólio em 1995, por ser mais agressivo à saúde humana que o de serpentina (crisotila). O mesotelioma, uma forma de câncer provocada por exposição a asbestos, é uma doença com longo período de latência e de difícil diagnóstico (e.g. Niklinski et al., 2004). 


\section{Resultados}

\subsection{Aspectos petrográficos e de campo}

As descrições aqui apresentadas referem-se aos afloramentos de metadolomitos, com ênfase nos sistemas formadores de talco e nos processos tectono-metamórficos ocorridos na região. O mapeamento geológico não está entre os objetivos do presente trabalho.

\subsubsection{Protolito dolomítico e metamorfismo regional}

Os metadolomitos do Grupo Itaiacoca constituem pacotes espessos e homogêneos, de cor cinza e granulação fina, conforme observado em porções afetadas pelo metamorfismo regional de baixo grau mas não por eventos de metamorfismo ou deformação superimpostos. Em campo é possível observar o acamamento sedimentar (So) marcado pela alternância de tons claros e escuros de cinza dados pela alternância rítmica de níveis com teores variáveis de matéria orgânica (Figura 6). A presença de estromatólitos e oólitos no Grupo Itaiacoca é conhecida de longa data (e.g. Almeida, 1956) e tais estruturas foram observadas em diversos pontos, inclusive na periferia de corpos de minério (Figura 7).

Os metadolomitos compostos apenas por fases carbonáticas e quartzo praticamente não apresentam registros do metamorfismo regional, apenas uma incipiente recristalização dos carbonatos, mas preservando sua granulação submilimétrica e coloração cinza dada pela presença de pequenas quantidades de matéria orgânica. Sua composição mineralógica é relativamente homogênea, com leitos localmente mais ricos em quartzo detrítico ou em calcita. Testes de coloração diferencial de carbonatos indicam que calcita ocorre, via de regra, em teores $<5 \%$ vol. Em rochas pouco deformadas observa-se um tênue acamamento marcado pela alternância de composição ora mais calcítica, ora mais dolomítica. Dentre as estruturas sedimentares primárias preservadas foram observadas estratificações e laminações sedimentares, de difícil identificação em superfícies não intemperisadas, raros leitos arenosos quartzosos (Figura 6b), em geral descontínuos e complexamente deformados. Os grãos detríticos de quartzo apresentam recristalização incipiente, mas não mostram 
sinais de reação com dolomita, mesmo quando a alguns micrometros deles desenvolvese talco em planos de cisalhamento ou fraturas de escala microscópica.

Além das feições primárias acima mencionadas, foram observadas brechas formadas por blocos angulosos de metadolomito fino imersos em matriz igualmente metadolomítica de granulação fina (Figura 8), não apresentando feições de deformação e recristalização. Esta brecha foi observada em uma pedreira (PTI 01), em uma faixa subvertical bem definida, sugerindo inclusive tratar-se de uma possível estrutura sinsedimentar de colapso. Estas brechas diferem das diversas gerações de brechas tectônicas observadas na região, que se caracterizam pela moagem do metadolomito original e pelo contraste de cor textura entre os clastos metadolomíticos cinzentos de granulação fina e a matriz dolomítica branca de granulação média a grossa (Figura 9). Localmente percebe-se a sobreposição de brechas com teores diferentes de matriz, sugerindo fenômenos recorrentes de brechação e recristalização de carbonatos.

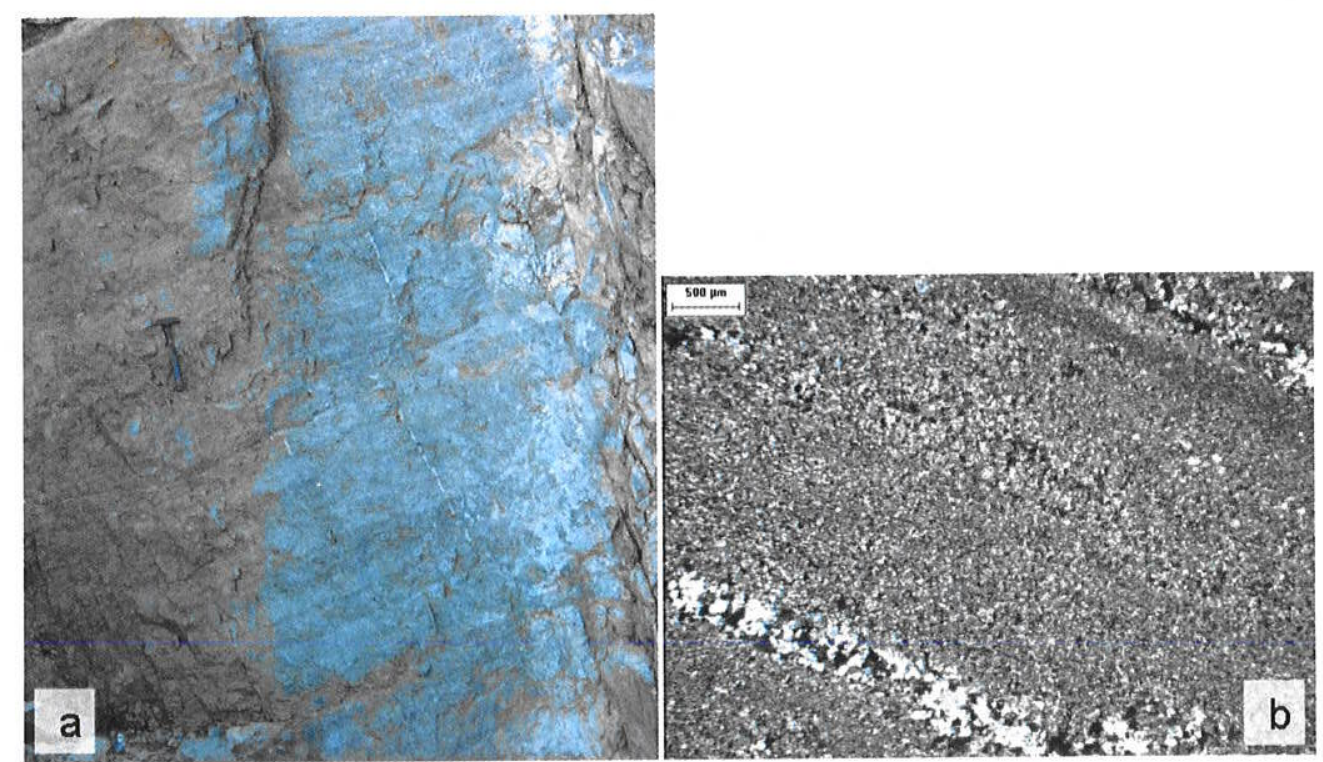

Figura 6. Aspecto em afloramento da superfície original de sedimentação $\left(\mathrm{S}_{0}\right)$ subhorizontal dos metadolomitos do Grupo Itaiacoca (ponto PTI 01) (a) em afloramento; (b) detalhe de camadas de grãos de quartzo em lâmina petrográfica. 


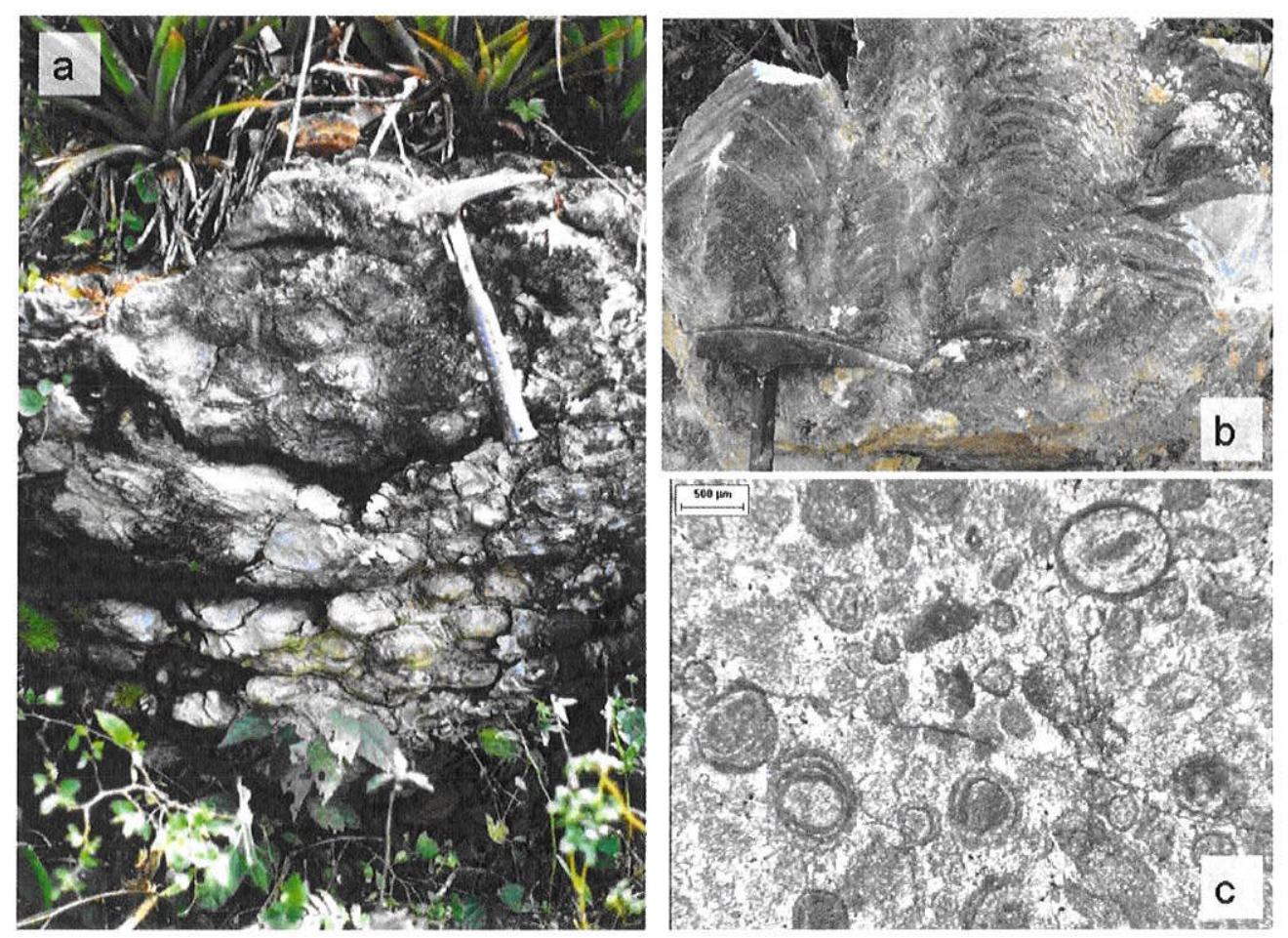

Figura 7. Estruturas sedimentares em metadolomito: (a) estromatólitos em afloramento; (b) estromatólitos em amostra de mão; (c) oólitos em lâmina petrográfica (ponto PTI 22).

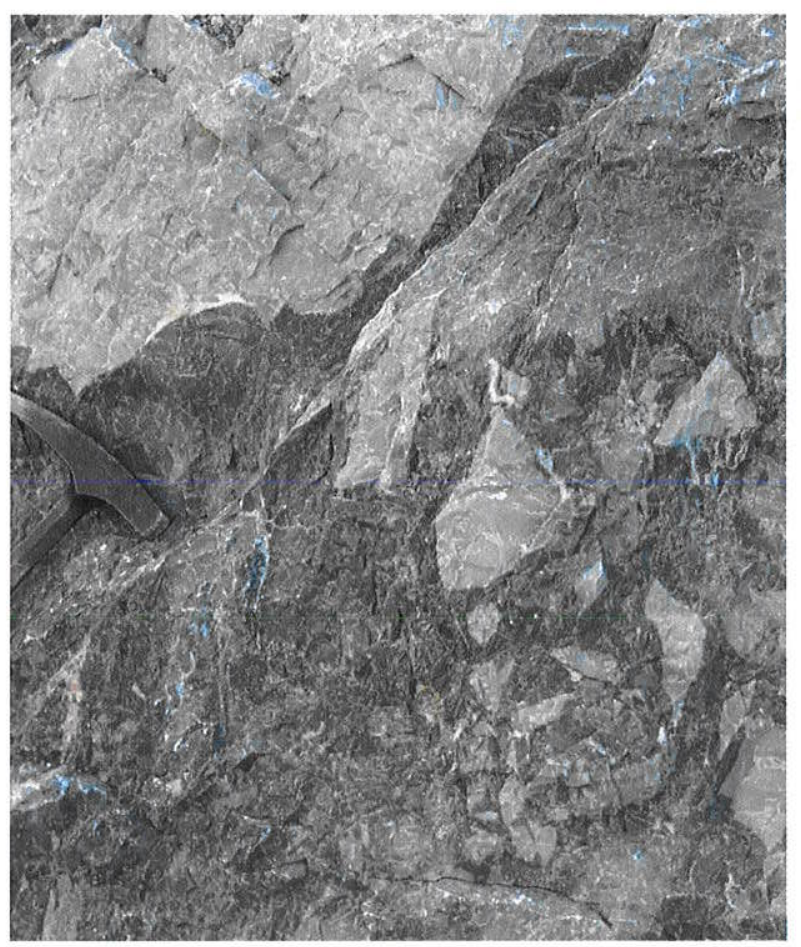

Figura 8. Brechas não-tectônicas em vista panorâmica e de detalhe (ponto PTI 01). 

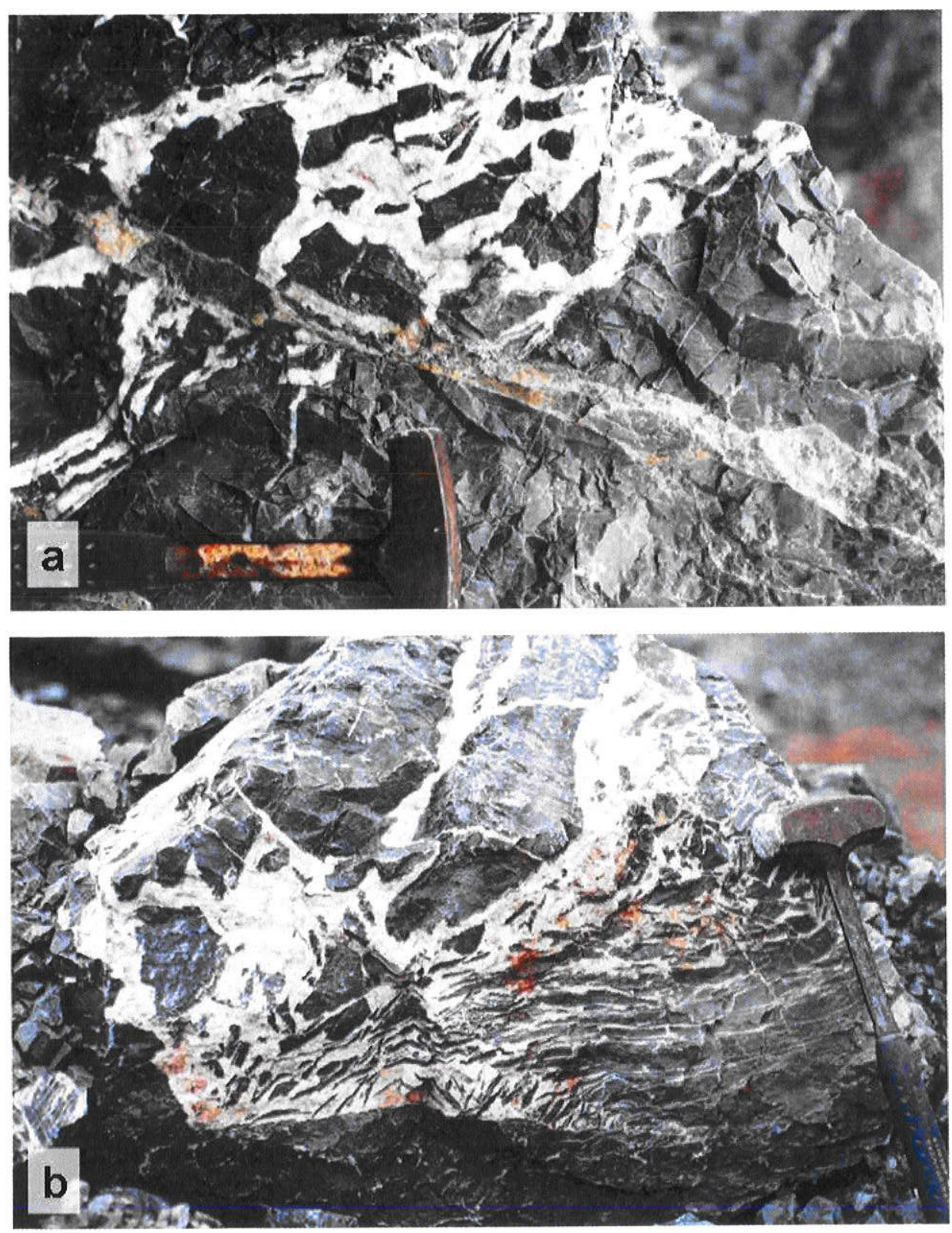

Figura 9. Brechas tectônicas em afloramento (ponto PTI 01): (a) sobreposição de uma brecha com matriz menos abundante sobre uma brecha anterior, com abundante matriz carbonática branca; (b) detalhe da brecha com moagem e transporte pouco pronunciado de clastos. 


\subsubsection{Metamorfismo dinâmico-hidrotermal}

O contato entre o Grupo Itaiacoca e o Complexo Granítico Três Córregos não apresenta evidências de metamorfismo termal, sendo eminentemente tectônico, definido pela Zona de Cisalhamento de Itapirapuã. Apesar dos dados regionais da literatura indicarem movimento transcorrente predominantemente dextral, planos de cisalhamento de alto ângulo contendo talco apresentam estrias de atrito que indicam rejeitos em diversos sentidos e ângulos, posto que o talco serviu de lubrificante para posteriores reativações tectônicas destes planos.

A abundância de veios de quartzo concordantes e discordantes, deformados em grau variável, indica aporte de fluidos hidrotermais ricos em sílica através da zona de cisalhamento em todas as etapas de sua evolução. Nos metadolomitos, o metamorfismo hidrotermal associado à deformação heterogênea promoveu intensa talcificação, transformando-os em talco xistos (Figura 10). As faixas de talco xisto chegam a atingir dezenas de metros de espessura e estendem-se por até centenas de metros na direção da foliação. As feições anastomosadas com porfiroblastos de calcita, veios lenticularizados de quartzo e fragmentos lenticulares de metadolomito repetem-se em escala de campo até em escala de lâmina petrográfica, em um padrão de autosimilaridade típico das foliações de cisalhamento.

A heterogeneidade da deformação de cisalhamento é evidente por exemplo na Mina Grande (PTI 22), onde, ao lado das zonas de cisalhamento principais, há planos progressivamente mais espaçados de cisalhamento e talcificação, com teores de talco descrescentes à medida em que se afastam do eixo do cisalhamento principal (Figura $11)$.

Os talco xistos são rochas de textura lepidoblástica, granulação fina e mineralogia simples, compostas predominantemente por talco, com porfiroblastos de calcita idiomórfica e fragmentos de metadolomito na forma de lentes concordantes com a foliação. $O$ talco apresenta-se com coloração predominantemente cinza clara a localmente rosada, esverdeada ou mesmo negra, sendo esbranquiçado onde afetado por intemperismo. Em lâmina petrográfica se observa o talco em palhetas com dimensões inferiores a $10 \mu \mathrm{m}$, formando uma textura lepidoblástica e estrutura xistosa anastomosada, onde os filossilicatos envolvem fragmentos de metadolomito parcialmente talcificados e porfiroblastos de calcita sintectônica, ambos com dimensões 
variando de micrométrica a decimétrica. É rara a ocorrência de clorita e serpentina, as quais se associam ao talco xistos, particularmente nas extremidades dos veios de talcificação. A tremolita fibrosa também está presente nos talco xistos em teores muito baixos.
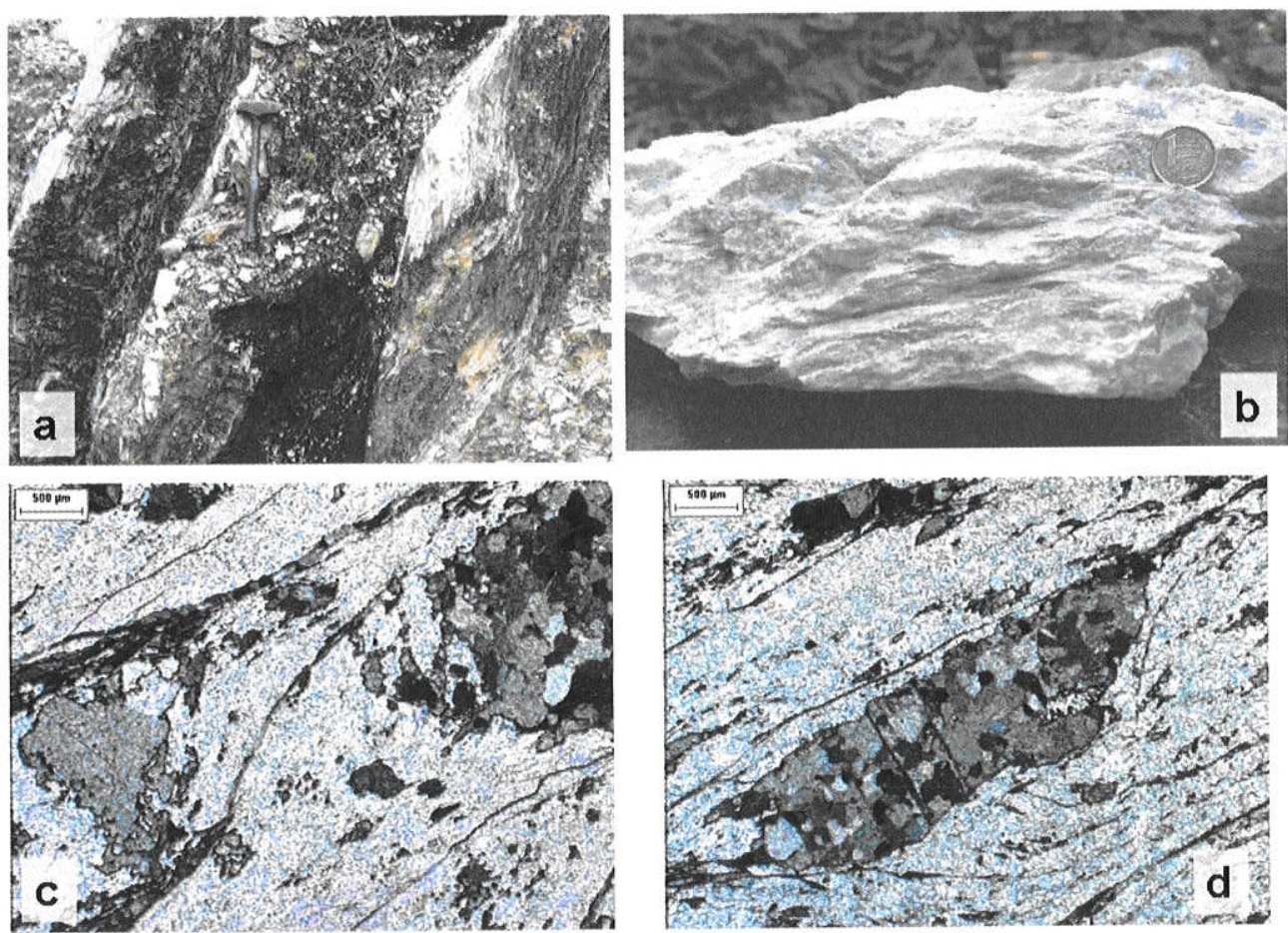

Figura 10. Talco xisto milonítico em zona de cisalhamento transcorrente (ponto PTI 22). As faixas anastomosadas onde se concentra a deformação mais intensa (à direita) envolvem frações metadolomíticas preservadas em graus variados (à esquerda). (a) afloramento; (b) amostra de mão.; (c) lâmina petrográfica, porfiroclasto de metadolomito fragmentado e rotacionado na matriz talcosa; (d) lâmina petrográfica, porfiroblasto de calcita em meio à matriz talcosa. 

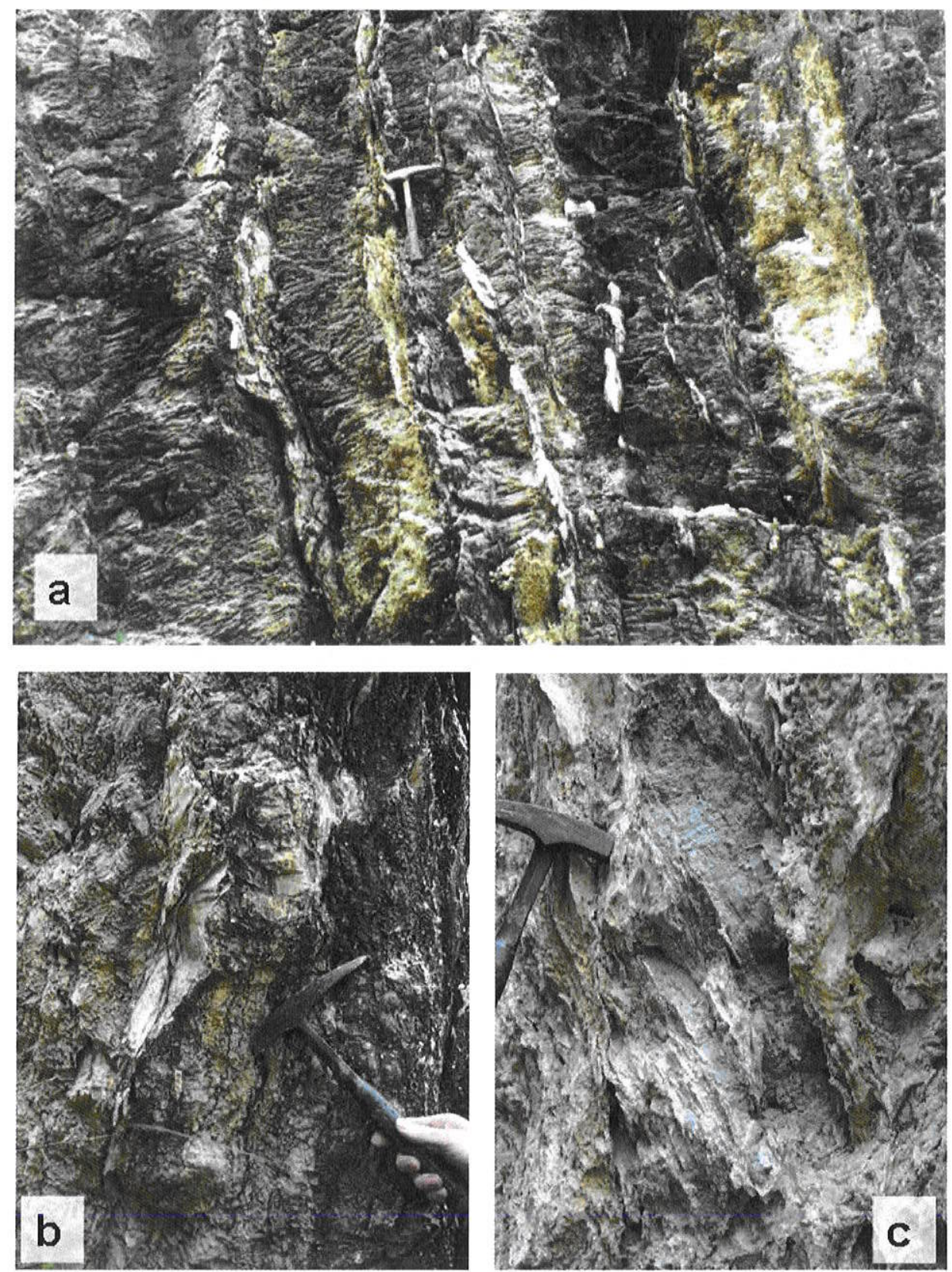

Figura 11. Borda de uma zona de cisalhamento transcorrente com mineralização tipo talco xisto (ponto PTI 22). (a) espaçamento regular de faixas miloníticas com talco xisto (faixas claras) cortando o metadolomito; (b) detalhe de plano de foliação milonítica anastomosada; (c) detalhe de foliação milonítica cortando a estratificação original (So).

Foi observada a aparente ocorrência de deformação em regime rúptil e em regime dúctil numa mesma zona de deformação heterogênea, em escala de poucos 
centímetros. Por vezes, em um mesmo plano há porções brechadas, cimentadas por matriz carbonática branca, ao lado de porções dúcteis, onde houve formação de talco em porções limitadas no interior dos planos de cisalhamento (Figura 12). O metadolomito nas imediações das zonas de cisalhamento pode aparecer preservado, inclusive com estromatólitos (PTI 22), ou localmente esbranquiçado. Esta feição sugere interessantes aspectos relacionados ao regime de fluidos durante o cisalhamento, posteriormente comentados. Importantes jazidas de talco da porção sul do Grupo Itaiacoca, como as Minas Grande (ponto PTI22) e Paranaense (ponto PTI02, antiga Mina São José), localizam-se ao longo de ramificações da Zona de Cisalhamento de Itapirapuã, que define o contato tectônico entre metadolomitos e o Complexo Granítico Três Córregos.

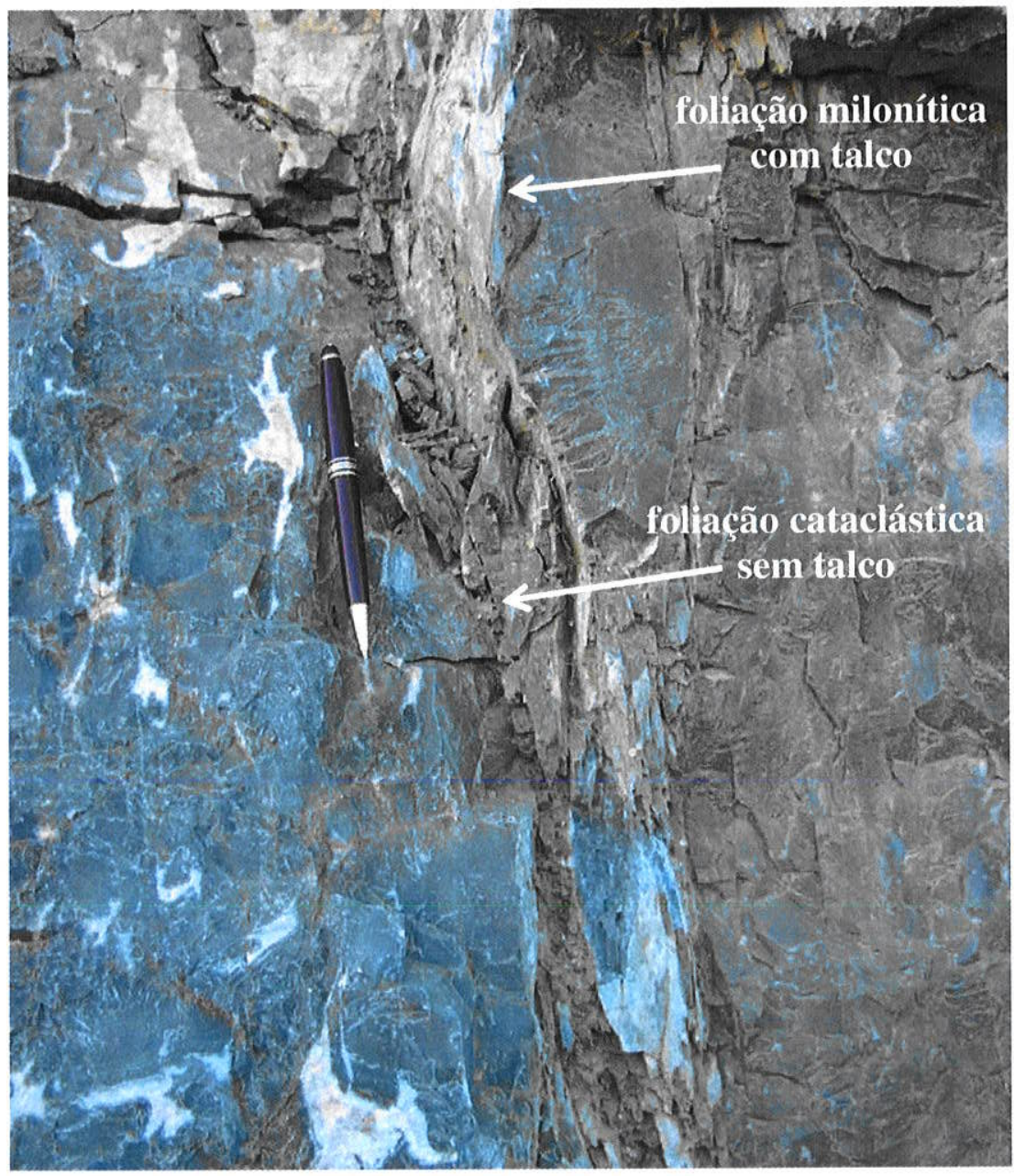

Figura 12. Aparente transição local de regime de deformação rúptil (brechas) para regime dúctil (foliação com talco) na porção central da imagem (ponto PTI 01). 
Os corpos de metabasitos em contato com os metadolomitos talcificados sofreram alteração hidrotermal com epidotização generalizada. Os quartzitos apresentam foliação de cisalhamento e abundantes veios de quartzo.

\subsubsection{Metamorfismo termal I - Complexo Granítico Cunhaporanga}

A auréola de contato do Complexo Granítico Cunhaporanga sobre os metadolomitos e metapelitos do Grupo Itaiacoca não pode ser observada de modo contínuo em campo, dada a escassez de afloramentos. Além da propensão à dissolução química das rochas carbonáticas, há um aparente rebaixamento na porção sul do Complexo Granítico Cunhaporanga, cujos afloramentos são raros, tipicamente na forma de blocos arredondados de dimensões métricas. $O$ granito predominante nestes blocos é fanerítico inequigranular, e em uma apófise observada em contato direto com o metadolomito (mármore dolomítico, Ponto PTI07 Mina Irapuru) o granito transiciona para um quartzo pórfiro de matriz afanítica.

Os metadolomitos cinzentos sofreram recristalização ao longo do contato, tornando-se mármores granoblásticos brancos, com veios e bolsões descontínuos com tremolita, quartzo, calcita metamórfica, talco, diopsídio e forsterita, frequientemente com zoneamento concêntrico, com paragêneses de mais alto grau nos núcleos, envoltas por paragêneses retrometamórficas (Figura 13). A tremolita ocorre também em porfiroblastos aciculares milimétricos isolados, alinhados ao longo de fraturas, às vezes acompanhada de calcita metamórfica ou em parte substituída por talco (Figura 13d). O contato das rochas metassedimentares com o granito foi localmente afetado por falhas menores, mas prevalece seu caráter intrusivo com evidências de percolação de fluidos aquosos com alta atividade de sílica nas rochas encaixantes. A percolação não foi pervasiva, tendo sido canalizada em descontinuidades estruturais como planos de acamamento e fraturas. $O$ traçado das isógradas do metamorfismo termal não podem ser inferido em campo, em parte pela descontinuidade das exposições, mas principalmente porque a blastese e a distribuição dos minerais-índice (talco, tremolita, diopsídio, forsterita) está associada aos canais preferenciais de percolação dos fluidos, refletidos nas estruturas concêntricas anteriormente mencionadas. Nos filitos e metarritmitos 
próximos ao contato, desenvolveram-se porfiroblastos de andalusita quiastolítica (Figura 14) e granada, além de sillimanita (fibrolita) paralela à foliação local.

O mineral índice mais abundante nos mármores dolomíticos é a tremolita, que ocorre em prismas longos, isolados, dispostos em planos de fratura paralelos, em agregados lenticulares e pequenos bolsões, chegando a formar agregados fibro-radiados de aspecto felpudo. Em seção delgada, é possível identificar "trilhas" de tremolita, com indivíduos prismáticos-longos isolados, iso-orientados, conectados pelas extremidades por uma rede de fraturas muito finas, praticamente imperceptíveis.
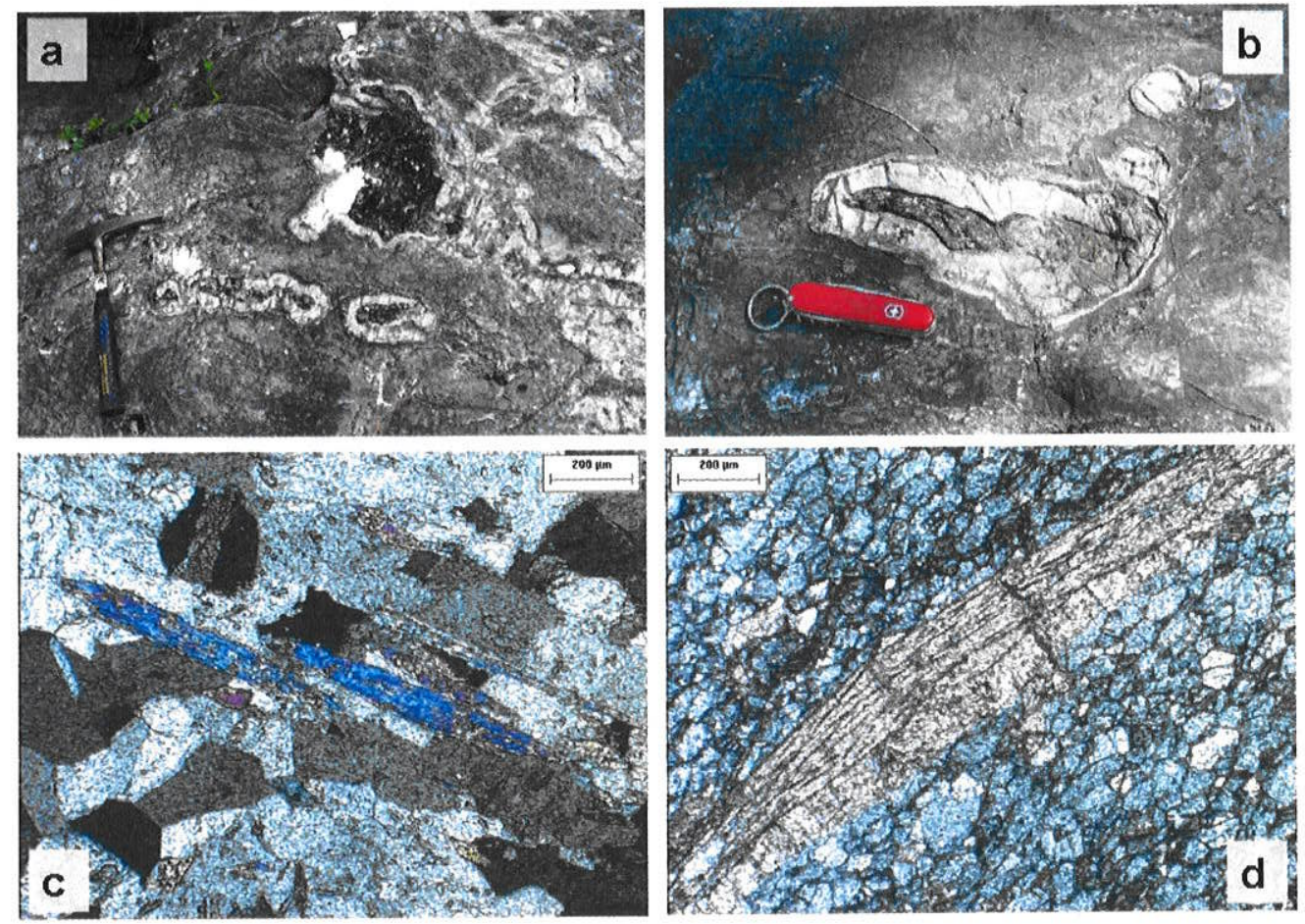

Figura 13. Mármore dolomítico nas proximidades do contato intrusivo entre o Complexo Granítico Cunhaporanga e o Grupo Itaiacoca. (a) visão panorâmica em afloramento; (b) detalhe de estrutura concêntrica de metamorfismo de contato, com paragêneses de temperatura mais alta na parte central (forsterita, diopsídio, tremolita) e mais baixa nas bordas (talco, quartzo, dolomita); (c) tremolita acicular em matriz carbonática granoblástica (polarizadores cruzados); (d) tremolita acicular bordejada por calcita (polarizadores paralelos com tingimento diferencial - calcita incolor, dolomita azul). 


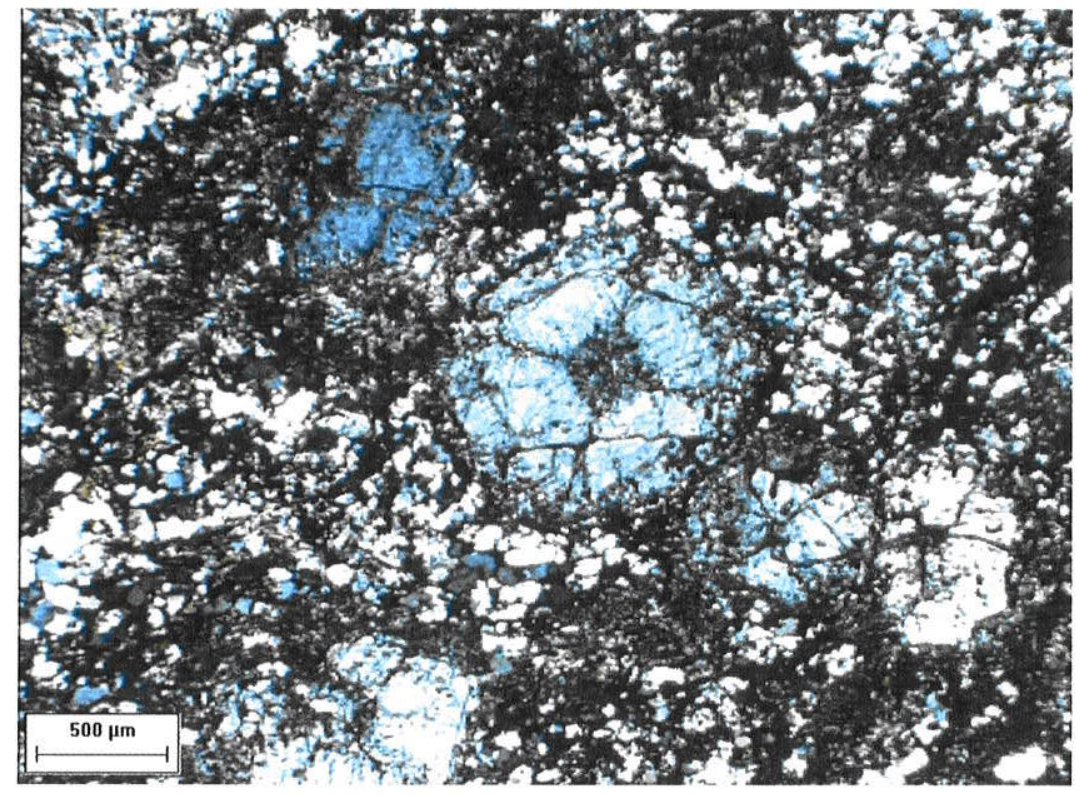

Figura 14. Fotomicrografia com polarizadores cruzados de metapelito com andalusita na zona de metamorfismo de contato entre o Complexo Granítico Cunhaporanga e o Grupo Itaiacoca.

Apesar da presença de teores expressivos de tremolita, que podem atingir localmente até $10 \%$ em volume, os mármores dolomíticos formados pelo metamorfismo de contato são usados na indústria cerâmica pelo seu elevado conteúdo em $\mathrm{Mg}$ e excelente alvura. Não há evidências que vinculem jazidas de talco a este episódio metamórfico.

8.1.4. Metamorfismo termal II - enxame de diques de diabásio

Os diques de diabásio cretáceos do Arco de Ponta Grossa cortam todo o embasamento proterozóico paranaense entre o litoral e Ponta Grossa, tendo servido de canais de alimentação para os derrames basálticos da Formação Serra Geral. Os diques são verticais a subverticais, com orientação geral N40W e espessura da ordem de 1 a $10 \mathrm{~m}$ na região de estudo, ou ainda mais espessos como mencionados na literatura (Figura 15). Os diques mais espessos chegam a constituir um microgabro em suas porções centrais, gradando para diabásio fino até afanítico nas bordas. Estruturas em disjunção colunar são comuns, formando planos normais às bordas dos diques. Nas 
porções mais grossas a rocha é fanerítica fina, com plagioclásio cálcico (labradorita) e diopsídio em estrutura ofítica a sub-ofitítica, além de opacos abundantes (magnetita). Nas porções mais finas, o diabásio é afanítico, com ripas de labradorita e pseudomorfos de olivina preechidos por minerais secundários (clorita, serpentina) em matriz microcristalina a vítrea.

O enxame de diques de diabásio causou um segundo episódio termometamórfico, que se desenvolveu com limitada percolação de fluidos, em faixas milimétricas a centimétricas e em fraturas nas zonas marginais dos diques, gerando bandas irregulares de granulação muito fina, preto-castanho-verde, contendo serpentina nos metadolomitos contíguos (Figura 15). Megaxenólitos de metadolomito em diques espessos contêm crisotila, em parte pseudomorfa sobre olivina, e veios de brucita. Não houve formação de talco nas auréolas metamórficas destes diques, que truncam faixas de talco xisto. Nas proximidades de diques mais possantes, o metadolomito sofreu recristalização, transformando-se em mármore dolomítico e calcítico branco a distâncias de até vários metros do contato.

Em alguns casos, como na Mina São Judas (ponto PTI 37), a recristalização foi condicionada pela estratificação, produzindo leitos alternados de mármore calcítico branco e de metadolomito cinza fino (Figura 16). Metadolomitos previamente talcificados de modo incipiente foram transformados em mármores calcíticosdolomíticos talcosos brancos, usados pela indústria cerâmica. Próximo ao contato com dique o metadolomito se apresenta transformado em mármore branco, com superfícies de fraturamento preenchidas por carbonatos prismáticos aciculares. A cerca de 80 a $100 \mathrm{~m}$ de distância do contato o metadolomito cinza estratificado apresenta alternância de camadas brancas ("mármore") e cinza (rocha original). 

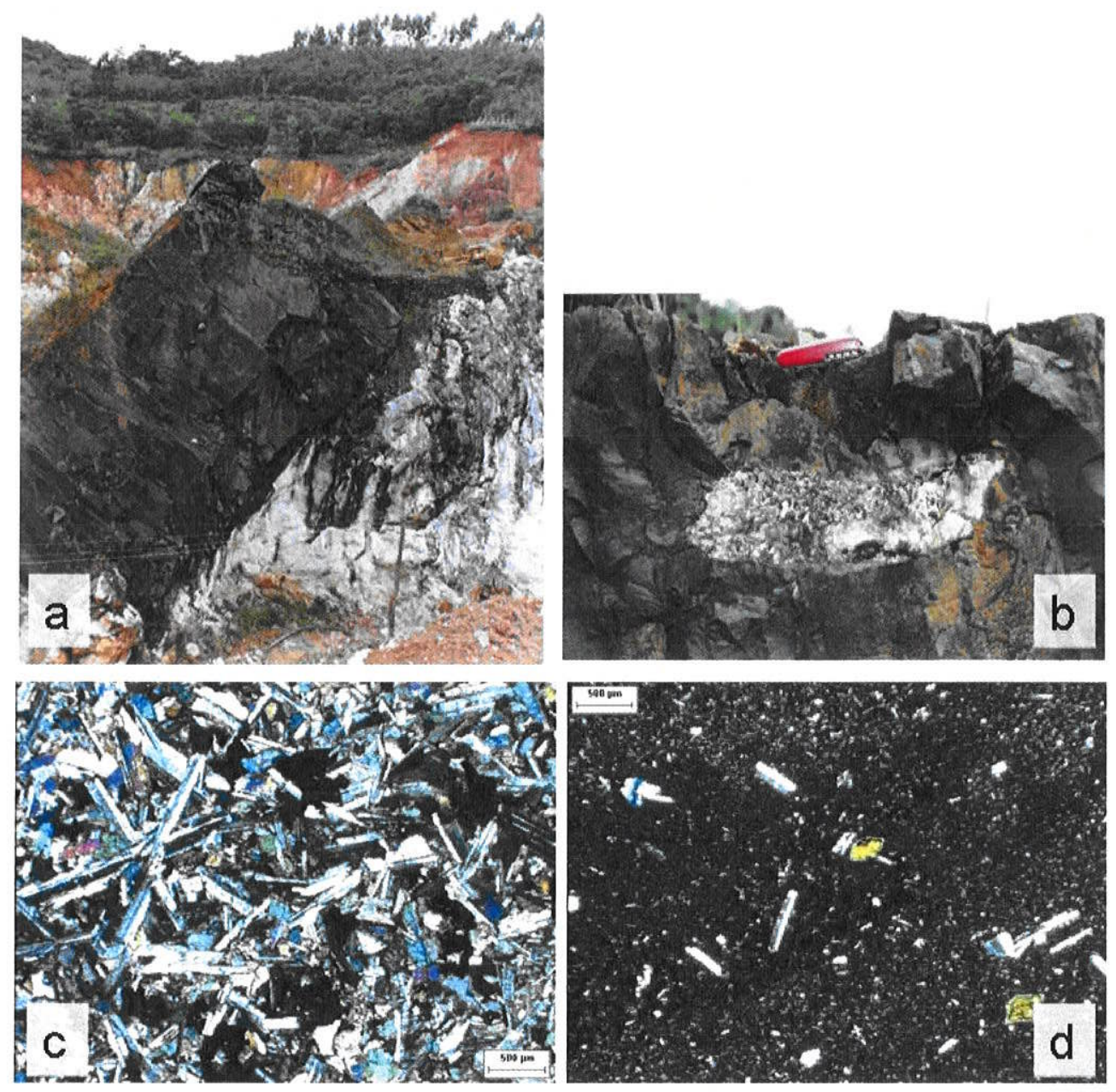

Figura 15. Contato intrusivo entre os diques de diabásio mesozóicos e o Grupo Itaiacoca (ponto PTI02). (a) visão panorâmica em afloramento, vide trator na parte superior direita da foto para escala; (b) xenólito de metadolomito na borda de dique de diabásio; (c) fotomicrografia com polarizadores cruzados da porção central de dique de diabásio, com textura fanerítica fina (microgabro); (d) fotomicrografia com polarizadores cruzados da borda de dique de diabásio, com textura afanítica. 


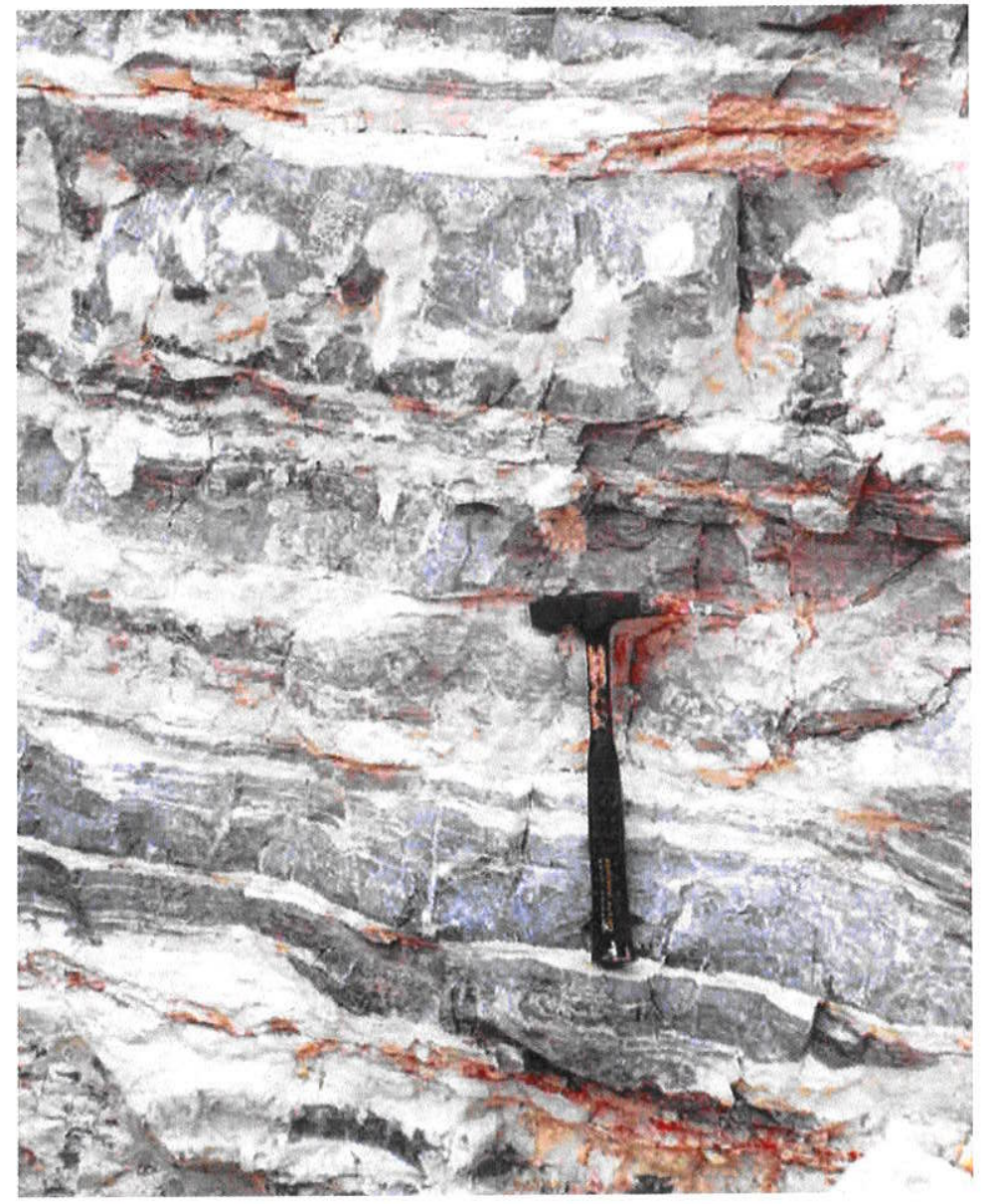

Figura 16. Metadolomito na zona de contato com os diques de diabásio mesozóicos, com planos e bolsões recristalizados concordantes com o acamamento sedimentar $\left(\mathrm{S}_{0}\right)$.

\subsection{Estilos de talcificação}

As observações de campo e petrográficas em diversas jazidas e ocorrências de talco no Grupo Itaiacoca permitiram a identificação de quatro estilos distintos de talcificação (Szabó et al., 2004, 2006; Andrade et al., 2005, in prep.). Os estilos de talcificação não são necessariamente independentes, mas podem podem estar relacionados por variações espaciais ou temporais dentro de um sistema de grande porte, conforme discutido oportunamente. As principais características encontram-se descritas a seguir: 
a) talco xistos em zonas de cisalhamento: as faixas de talco xisto são alongadas e estreitas, com centenas de metros de comprimento e larguras da ordem de dezenas de metros a alguns centímetros ou milímetros. O talco xisto se concentra ao longo da zona de cisalhamento transcorrente de Itapirapuã e suas ramificações, principalmente na porção meridional do Grupo Itaiacoca. É nesta região que se localizam as jazidas de talco de mais alta pureza. A talcificação é auto-similar em diversas escalas, com lentes carbonáticas envoltas por planos anastomosados de talco. O talco forma lamelas bem desenvolvidas de coloração de branca a rosa, bege, verde, cinza a negro (Figura 17a);

b) metadolomitos com talcificação incipiente: transformação não-pervasiva, formando veios e filmes de talco fino em descontinuidades estruturais como planos de estratificação, clivagens plano-axiais espaçadas e redes irregulares de fraturas. Este estilo de talcificação ocorre em metadolomitos fraturados próximos às zonas de cisalhamento, que localmente configuram brechas protocataclásticas. Sua ocorrência típica se dá nas porções residuais de minas de talco abandonadas, onde os minérios de alto teor foram exauridos. Trata-se, portanto, possivelmente de um material marginal aos minérios de alto teor (Figura 17b);

c) talco maciço, não foliado: metadolomitos não-cisalhados com bolsões irregulares de talco de granulação muito fina, maciço, branco a variegado em tons bege a rosa, sendo plástico quando úmido e pulverulento quando seco. $\mathrm{O}$ metadolomito transiciona para estes bolsões de maneira gradual, preservando sua estratificação original $\left(\mathrm{S}_{0}\right)$, indicando que a transformação não foi concomitante com deformação e que não houve grande variação volumétrica associada ao processo. Os bolsões de talco não têm relação espacial visível em campo com zonas de cisalhamento, intrusões graníticas ou diques de diabásio. As jazidas deste tipo de talco são lavradas em grande volume, com extração do minério por escavação mecanizada, com relação custo/benefício favorável oferecida pelo minério de extração mais simples, realizada através de escavação mecanizada, sem a necessidade de seleção manual, como nas lavras de talco foliado. As lavras de talco maciço distribuem-se predominantemente na região de Socavão, município de Castro (Figura 17c);

d) talco retrometamórfico: ocorre na auréola de contato do Complexo Granítico Cunhaporanga com o Grupo Itaiacoca, associado às lentes zonadas com forsterita, diopsídio, tremolita, quartzo e calcita e aos porfiroblastos isolados de tremolita nos 
mármores dolomíticos. Este tipo de talco não constitui concentrações de interesse econômico (Figura 17c).
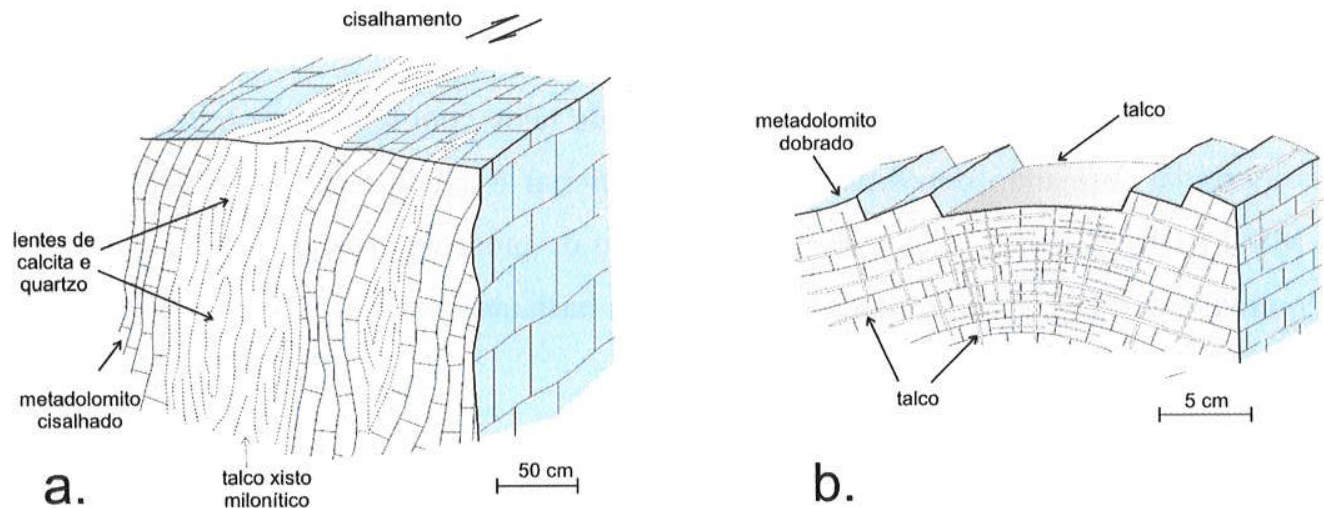

b.

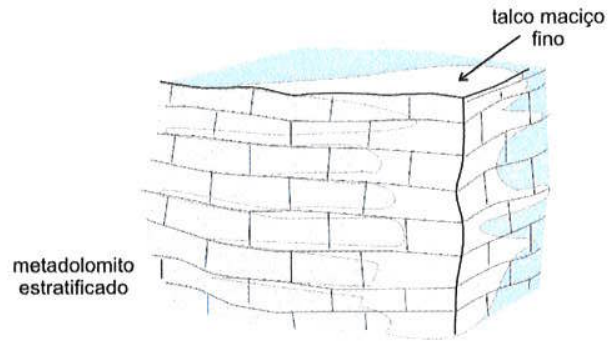

C.

$10 \mathrm{~cm}$

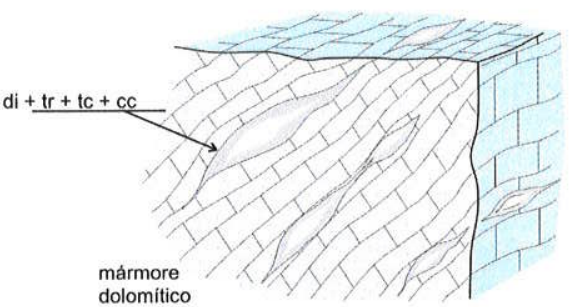

d.

$10 \mathrm{~cm}$

Figura 17. Blocos-diagramas com croquis dos estilos de talcificação no Grupo Itaiacoca.

As diferenças entre os tipos de talco economicamente mais relevantes se refletem no estilo dos blocos ("morros testemunhos") deixados para trás após a retirada do minério. No caso do talco foliado (tipo a), os blocos contêm restos de metadolomito cisalhado parcialmente talcificado e estão alinhados segundo a direção das zonas de cisalhamento. Nas cavas de talco maciço fino (tipo $c$ ), os blocos residuais são irregulares e apresentam acamamento basculado com dobras abertas, com feições de talcificação incipiente ao longo da estratificação e de estruturas estilolíticas. A dicotomia de tipos de talco nas jazidas do Grupo Itaiacoca foi mencionada por Araújo et al. (1987) e Gondim e Loyola (2002), quando se referem a dois tipos de minério lavrados, respectivamente, nos municípios de Ponta Grossa (distrito de Itaiacoca) e Castro (distrito de Socavão): o primeiro seria mais cristalino, lamelar-placóide, 
untuoso, com maior variedade e frequiência de minerais associados (tremolita, quartzo, clorita, montmorillonita), e formaria depósitos de maior volume, enquanto o segundo seria mais fino, pulverulento, microcristalino, com assembléia de minerais associados mais simples (clorita e quartzo) e de menor volume, ocorrendo em bolsões menores porém mais numerosos.

Há menção na literatura a ocorrências de talco com feições de retrabalhamento superficial formando depósitos de talco coluvionar e cárstico (Lima, 1993a; DNPMMINEROPAR, 1999). Nos trabalhos de campo do presente projeto apenas a variedade coluvionar foi observada, ainda que de modo bastante raro, na periferia de corpos de minério.

As principais jazidas de talco, metadolomito (corretivo para solos) e mármore dolomítico (cerâmica) do Grupo Itaiacoca estão apresentadas no mapa geológico simplificado da Figura 18. 


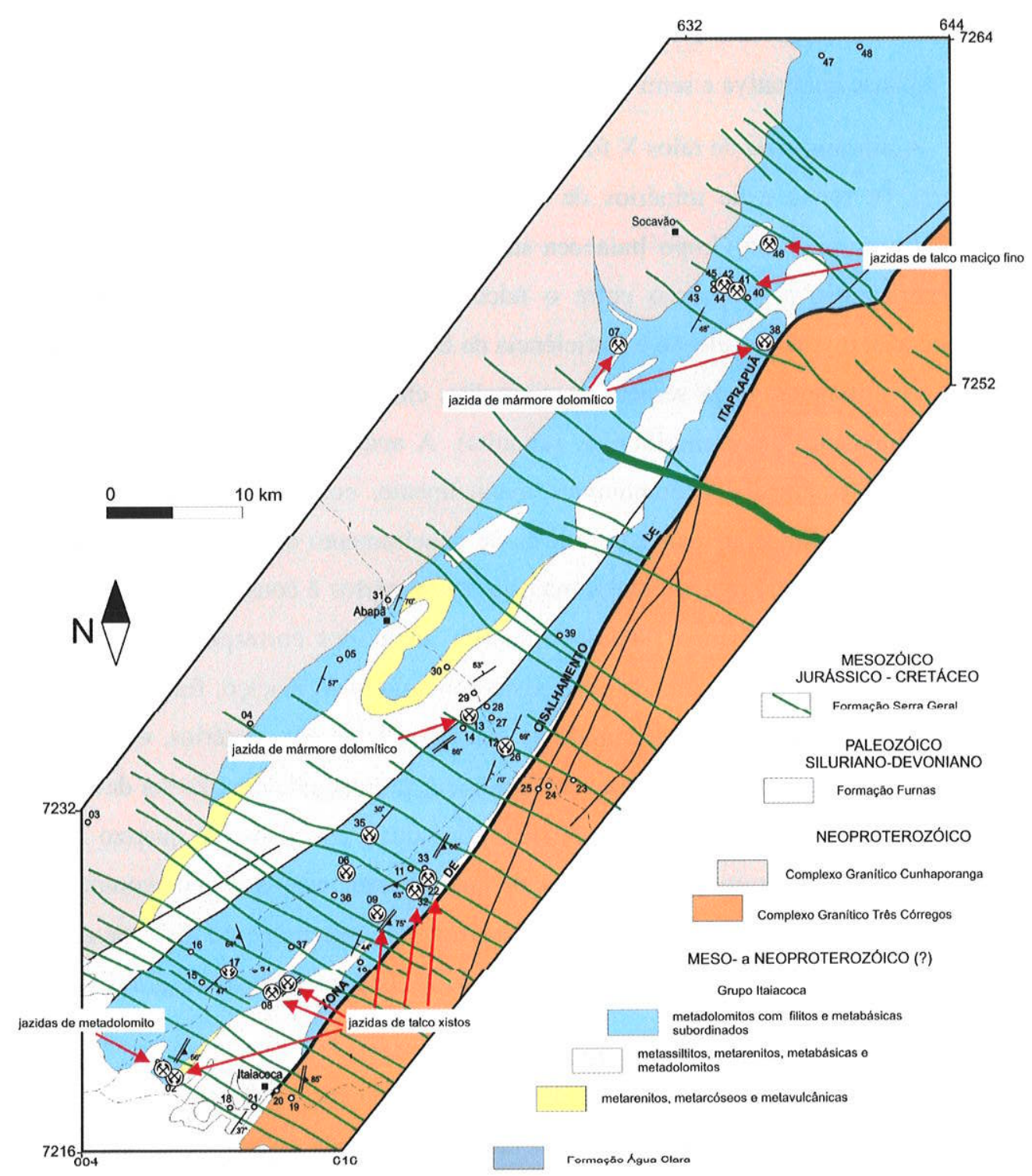

Figura 18. Mapa geológico simplificado do Grupo Itaiacoca entre Itaiacoca e Socavão (modificado de CPRM, 1977), com indicação das principais jazidas de talco, metadolomito e mármore dolomítico. 


\subsection{Difratometria de raios $X$}

8.3.1. Análise qualitativa e semi-quantitativa de fases

A difratometria de raios $\mathrm{X}$ foi utilizada para a identificação rotineira de fases em amostras de rocha e de minérios de talco. As fases minerais mais frequentemente associadas ao talco no Grupo Itaiacoca são quartzo, calcita e dolomita. Nos minérios pré-beneficiados, a proporção entre o talco e estas fases varia de acordo com a procedência, o grau de seleção e a eficiência de beneficiamento da amostra considerada. Foram identificados ainda serpentina, tremolita, clorita, brucita e outros filossilicatos menos abundantes (montmorillonita, saponita). A análise dos minérios de talco prébeneficiados (separados e cominuídos manualmente, com seleção granulométrica e mineralógica rudimentar realizada através de peneiramento em rampas), estocados no pátio das minerações, indicou que a maioria dos minérios é constituído de misturas de minerais, sendo que apenas $18 \%$ dos minérios analisados correspondia a talco puro, provenientes tanto das jazidas de talco xisto como de talco maciço, fino, pulverulento. Quartzo é a fase mineral mais comum associada ao talco nos minérios, ocorrendo em aproximadamente $60 \%$ das amostras analisadas. A presença de quartzo foi determinada na fração fina dos minérios pré-beneficiado, dos quais os clastos de quartzo maiores, correspondentes a fragmentos dos veios de quartzo mais espessos que acompanham o talco, haviam sido separados manualmente e através de peneiramento. Este quartzo mais fino corresponde provavelmente a vênulas associadas à talcificação e grãos detríticos do dolomito original.

A presença de tremolita foi detectada em minérios provenientes da área de Itaiacoca, domínio dos talco xistos associados às zonas de cisalhamento. Neste setor, tremolita fibrosa-acicular foi identificada também in situ, nas cavas da Mina Grande (PTI-22), Minas Guari e Serpentina (PTI-32), Pocinhos (PTI-09) e Mina da Transcomin (PTI-08). Neste último caso, a ocorrência de tremolita apresentava-se como um leito de material fino, de aspecto argiloso, esverdeado, intercalado entre o talco e os filitos encaixantes alterados, formando um "tremolitito", com minúsculos cristais prismáticoscurtos de terminações esfiapadas. Sua presença havia sido detectada nos minérios coletados no pátio de estocagem da empresa Transcomin em fevereiro de 2001, quando a Mina da Transcomin (PTI-08) estava em operação. Nas amostras de minério coletadas no mesmo local em fevereiro de 2002, não foi detectada a presença de tremolita, sugerindo que a fonte de contaminação havia sido este tremolitito encontrado na lavra 
agora paralizada. A presença de tremolita não foi detectada em amostras de minério de talco fino, maciço, pulverulento, provenientes da região de Socavão.

Os carbonatos acompanham sistematicamente o talco nas jazidas, porém calcita é a fase carbonática mais freqüente encontrada nos minérios, com dolomita praticamente ausente. Este fato se deve provavelmente ao modo de ocorrência de ambos, com a dolomita ocorrendo como lentes centi- a decimétricas em meio aos talco xistos, sendo portanto separada mais facilmente no processo de seleção manual, enquanto calcita ocorre intimamente associada ao talco, em filetes e grãos menores intersticiais, sendo portanto mais difícil de separar. Outros minerais reconhecidos nos difratogramas foram serpentina, clorita, montmorillonita e saponita. Pirita foi reconhecida apenas macroscopicamente na Mina Grande (PTI-22), em uma amostra.

A difratometria de raios $\mathrm{X}$ foi usada na análise semi-quantitativa de amostras contendo carbonatos (Tabela 5), posteriormente analisados em termos de suas razões de isótopos estáveis de carbono e oxigênio. Estes dados semi-quantitativos são apenas uma indicação aproximada da abundância maior ou menor das fases presentes em amostras selecionadas para análises isotópicas, que por sua vez representam os litotipos mais representativos. 
Tabela 5. Análise mineralógica semi-quantitativa por difratometria de raios $\mathrm{X}$ de amostras encaminhadas para análise isotópica de carbono e oxigênio $(\mathrm{cc}=$ calcita; dol $=$ dolomita; $q \mathrm{z}=$ quartzo; $\mathrm{tc}=$ talco; $\mathrm{ct}=$ clorita; liz = lizardita; anf = anfibólio; ar = aragonita).

\begin{tabular}{|c|c|c|c|c|c|c|c|c|c|}
\hline Amostra & comentário & $\mathrm{cc}$ & dol & $\mathrm{qz}$ & tc & $\mathrm{ct}$ & $\mathrm{liz}$ & $\operatorname{tr}$ & ar \\
\hline PTI $01 \mathrm{CA} 1$ & metadol. original & - & 100 & - & - & - & - & - & - \\
\hline PTY $01 \mathrm{CA} 2$ & $\begin{array}{l}\text { metadolomito estratificado } \\
\text { (So) com vênulas }\end{array}$ & 99,8 & 0,2 & - & - & - & - & - & - \\
\hline PTI $01 \mathrm{CC} 1$ & $\begin{array}{l}\text { brecha angulosa maciça } \\
\text { (clastos) }\end{array}$ & - & 100 & - & - & - & - & - & - \\
\hline PTI $01 \mathrm{CC} 2$ & $\begin{array}{l}\text { brecha angulosa maciça } \\
\text { (matriz) }\end{array}$ & - & 100 & - & - & - & - & - & - \\
\hline PTr 01 CD 1 & $\begin{array}{l}\text { brecha angulosa maciça } \\
\text { (clastos) }\end{array}$ & 0,2 & 99,8 & - & - & - & - & - & - \\
\hline PTI $01 \mathrm{CD} 2$ & $\begin{array}{l}\text { brecha angulosa maciça } \\
\text { (matriz) }\end{array}$ & 0,4 & 99,6 & - & - & - & $\sim$ & - & - \\
\hline PTI $01 \mathrm{CG}$ & $\begin{array}{l}\text { dolomita em cavidade de } \\
\text { brecha }\end{array}$ & - & 100 & - & - & - & - & - & - \\
\hline PTI 01 CE I & $\begin{array}{l}\text { brecha com cavidades } \\
\text { (clastos) }\end{array}$ & - & 100 & - & - & - & - & - & - \\
\hline PTI 01 CE 2 & brecha com cavidades (matriz) & - & 100 & - & $\sim$ & 。 & - & - & - \\
\hline PTI $01 \mathrm{CH} 1$ & $\begin{array}{l}\text { dolomita, cristal grande } \\
\text { branco }\end{array}$ & - & 100 & - & * & - & - & - & - \\
\hline PTI $01 \mathrm{CH} 2$ & dolomita, matriz cinza fina & 0,4 & 99,2 & 0,4 & - & - & - & - & - \\
\hline PTI 01 CI 1 & brecha (clasto escuro) & 0,3 & 99,7 & - & - & - & - & - & - \\
\hline PTI $01 \mathrm{Cl} 2$ & brecha (matriz) & 2,2 & 96,5 & 0,5 & 0,8 & - & - & - & - \\
\hline PTI $01 \mathrm{CJ} 1$ & brecha (clasto) & - & 100 & - & - & - & - & - & - \\
\hline PTI $01 \mathrm{CJ} 2$ & brecha (matriz) & - & 100 & - & - & - & - & - & - \\
\hline PTI 02 DA & metadolomito cinza claro & 0,7 & 96 & - & 3,7 & - & - & - & - \\
\hline PTI 02 DF & $\begin{array}{l}\text { metadolomito brechado com } \\
\text { talco e calcita }\end{array}$ & 84,5 & - & 0,6 & 14,8 & - & - & - & - \\
\hline PTI 02 D2 & & 62,5 & 5,6 & - & 31,9 & - & - & - & - \\
\hline PTI 02 DK & $\begin{array}{l}\text { calcita geminada com feições } \\
\text { concêntricas }\end{array}$ & 97,9 & - & 2,2 & - & - & - & - & \% \\
\hline PTI 02 DO & metadolomito & 2,0 & 93 & 3,8 & 1,2 & - & - & - & - \\
\hline PTI $02 \mathrm{DP}$ & metadolomito & 3,4 & 94,5 & 2,1 & - & - & - & - & - \\
\hline PTI 02 DS & veios & 100 & - & - & - & - & - & - & - \\
\hline PTI 05 a AG & $\begin{array}{l}\text { tremolita mármore no contato } \\
\text { com granito }\end{array}$ & 0,9 & 99,6 & - & - & - & - & - & - \\
\hline PTI 06 BA & $\begin{array}{l}\text { metadolomito com talcificação } \\
\text { incipiente }\end{array}$ & 6,0 & 90,1 & - & 1,8 & 2,1 & - & - & - \\
\hline PTI $22 \mathrm{BG}$ & veio de $\mathrm{q} z$ leitoso com calcita & 83,7 & - & 2,4 & 14,0 & - & - & - & - \\
\hline PTI $22 \mathrm{CA}$ & metadolomito estratificado & 3,0 & 94,4 & - & 0,7 & 0,4 & - & - & - \\
\hline P'TI 22 CB & $\begin{array}{l}\text { metadolomito esiratificado } \\
\text { com estromatólitos }\end{array}$ & 2,6 & 91,5 & - & 4,7 & 1,2 & - & - & - \\
\hline
\end{tabular}


Tabela 5. (continuação).

\begin{tabular}{|c|c|c|c|c|c|c|c|c|c|}
\hline Amostra & comentário & $\mathrm{cc}$ & dol & $\mathrm{qz}$ & $\mathrm{tc}$ & $\mathrm{ct}$ & liz & $\operatorname{tr}$ & ar \\
\hline PTI $22 \mathrm{CD}$ & talco xisto & 29,7 & 10,5 & 2,0 & 57,7 & - & - & - & - \\
\hline PTI $22 \mathrm{CE}$ & talco xisto & 86,1 & - & - & 13,9 & - & - & - & $-\cdots$ \\
\hline PTI $22 \mathrm{CJ}$ & veio que quartzo dobrado & 2,9 & - & 92,4 & 3,8 & - & - & - & - \\
\hline PTI $22 \mathrm{CM}$ & calcita supergênica & 96,1 & - & - & 3,9 & - & - & - & - \\
\hline PTI $22 \mathrm{CN}$ & calcita supergênica & 67,3 & - & 27,3 & 5,3 & - & - & - & - \\
\hline PTI 42 AA & metadolomito cinza & 0,5 & 99,5 & - & - & - & - & - & - \\
\hline PTI $42 \mathrm{AC} 1$ & metadolomito cinza & 3,6 & 95,4 & - & 1,0 & - & - & - & - \\
\hline PTI $42 \mathrm{AC} 2$ & borde de veio de calcita & 63,8 & 4,6 & - & 31,6 & - & - & - & - \\
\hline PTI $42 \mathrm{AC} 3$ & talco maciço fino & 92,3 & - & - & 7,7 & - & - & - & - \\
\hline PTI 42 AE 1 & brecha (clasto) & 76,2 & 3,8 & $\sim$ & - & - & - & - & - \\
\hline PTI 42 AE 2 & brecha (matriz) & 72,7 & 1,1 & - & - & - & 26,2 & - & - \\
\hline PTI 42 AE 3 & brecha (clasto) & 35,6 & 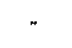 & - & - & - & 4,9 & - & 59,4 \\
\hline PTI $42 \mathrm{AJ}$ & brecha (clasto) & 94,0 & - & n & 6,0 & - & - & - & - \\
\hline PTI $42 \mathrm{AL}$ & talco maciço fino & - & - & - & 100 & $*$ & - & - & - \\
\hline PTI $43 \mathrm{AA}$ & $\begin{array}{l}\text { tremolita mármore no contato } \\
\text { com granito }\end{array}$ & 6,9 & 84,5 & - & 4,0 & - & - & - & - \\
\hline PTI $43 \mathrm{AB}$ & tremolita mármore sacaróide & 7,0 & 93,0 & - & - & - & - & - & - \\
\hline PTI $47 \mathrm{AC}$ & $\begin{array}{l}\text { tremolita mármore sacaróide } \\
\text { com calcita }\end{array}$ & 0,5 & 93,0 & - & - & - & - & - & - \\
\hline PTI $65 \mathrm{~A}$ & metadolomito & - & 100 & " & - & - & - & - & - \\
\hline PTl $65 \mathrm{~B}$ & metadolomito & - & 100 & - & - & - & - & 。 & - \\
\hline PTI $65 \mathrm{C}$ & metadolomito talcificado & 0,1 & 94,5 & 1,5 & 3,9 & - & - &. & - \\
\hline
\end{tabular}

\subsubsection{Difratometria de raios X e método de Rietveld}

O método de Rietveld é um procedimento matemático aplicado à análise difratométrica de alta resolução que permite o refinamento de parâmetros de estrutura cristalina e a análise quantitativa de fases em amostras pulverizadas (método do pó). Este estudo de detalhe foi aplicado a quatro amostras de minérios de talco do Grupo Itaiacoca, sendo três amostras de talco xisto (ponto PTI 02, Mina Paranaense) e uma de talco fino maciço (ponto PTI 42), com o intuito de se observar possíveis diferenças estruturais. As amostras de talco xisto são constituídas por talco puro e se distinguem pela cor: PTI02 cinza, PTI02 branco e PTI02 rosa.

Numa primeira etapa, as amostras foram pulverizadas em moinho de panela de ágata. Como será discutido oportunamente, a análise pelo método de Rietveld revelou 
discrepâncias expressivas entre a amostra e os dados de estrutura do talco disponíveis na literatura. Considerando-se a possibilidade de incremento da microdeformação através de moagem, foi feita uma nova preparação, com a desagregação da amostra em via úmida com pistilo de ágata, seguida da deposição do material sobre porta-amostras de vidro. A intensidade geral foi reduzida, devido ao menor volume de amostra da amostra desagregada em via úmida (Figura 19), mas mesmo assim houve uma sutil melhoria de resolução e, portanto, as comparações a seguir serão feitas entre amostras desagregadas em via úmida. Em comparação com a desagregação de talco com pistilo de ágata em água, a preparação por moagem produziu um volume maior de amostras, além de uma orientação preferencial aparentemente menos pronunciada. As amostras preparadas por via úmida apresentam orientação preferencial mais pronunciada, realçando os picos referentes aos planos $(O O l)$, além de gerar menor microdeformação nas lamelas de talco.

A simples comparação qualitativa dos difratogramas anterior à análise pelo método de Rietveld evidenciou a existência de diferenças estruturais entre as três amostras de talco procedentes da mesma jazida (talco xisto, PTI02), visíveis nos intervalos angulares $5-12^{\circ}$ e $18-40^{\circ}$ (2-teta) que contêm os principais picos difratométricos do talco (Figura 20). A amostra PTI02 branca praticamente não apresenta os picos (020), (130) e (131), claramente visíveis nas demais amostras. Uma diferença mais sutil, mas importante, é a maior largura e assimetria do pico principal, (001), da amostra PTI02 rosa em relação às demais.

A comparação qualitativa entre amostras de talco dos minério tipo talco xisto (PT102) e tipo maciço fino (PTI42) foi dificultada pela contaminação nesta última amostra por quartzo e calcita, devido à dificuldade em se obter concentrados minerais puros nesta faixa granulométrica (Figura 21). 


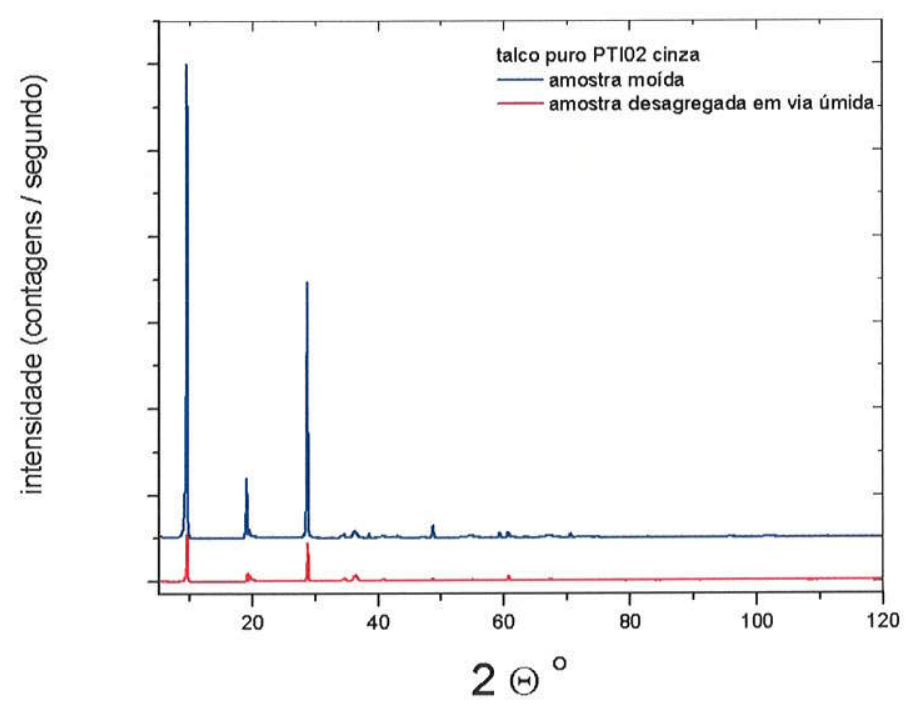

Figura 19. Difratogramas de raios X para comparação entre amostra moída em moinho de panela de ágata e amostra desagregada por via úmida e depositada em porta-amostras de vidro. A diferença na intensidade entre as amostras se deve ao maior volume de amostra analisado na amostra moída. A escala absoluta de intensidade consta apenas por referência e foi alterada para permitir a melhor comparação das amostras.

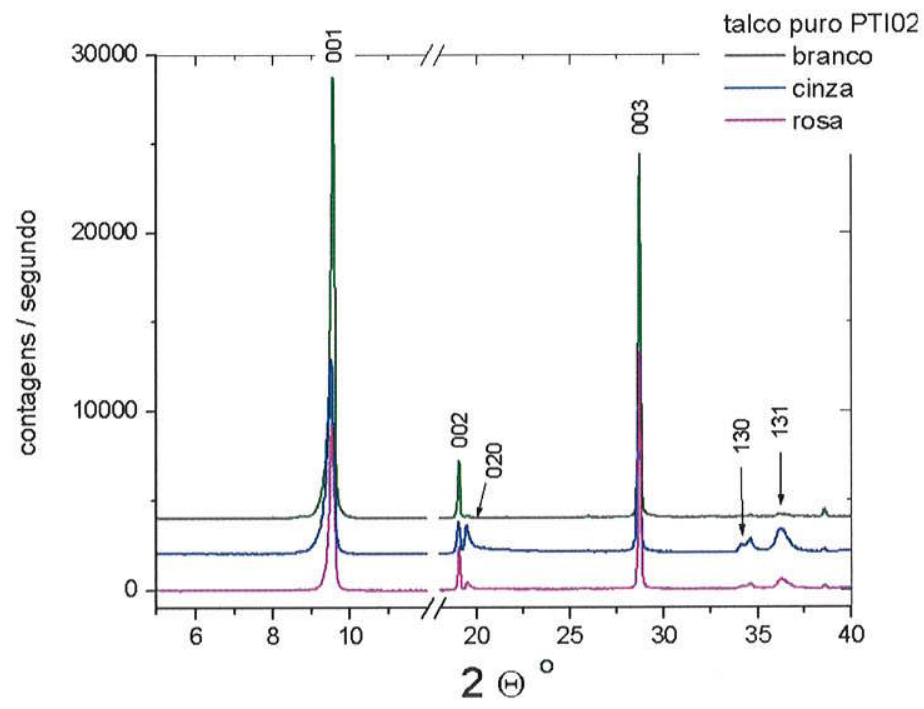

Figura 20. Difratogramas de raios $\mathrm{X}$ de três amostras de talco puro provenientes do ponto PTI 02 (talco xisto), nos intervalos angulares $5-12^{\circ}$ e $18-40^{\circ}$. A escala absoluta de intensidade consta apenas por referência e foi alterada para permitir a melhor comparação das amostras. As amostras foram desagregadas por via úmida. 


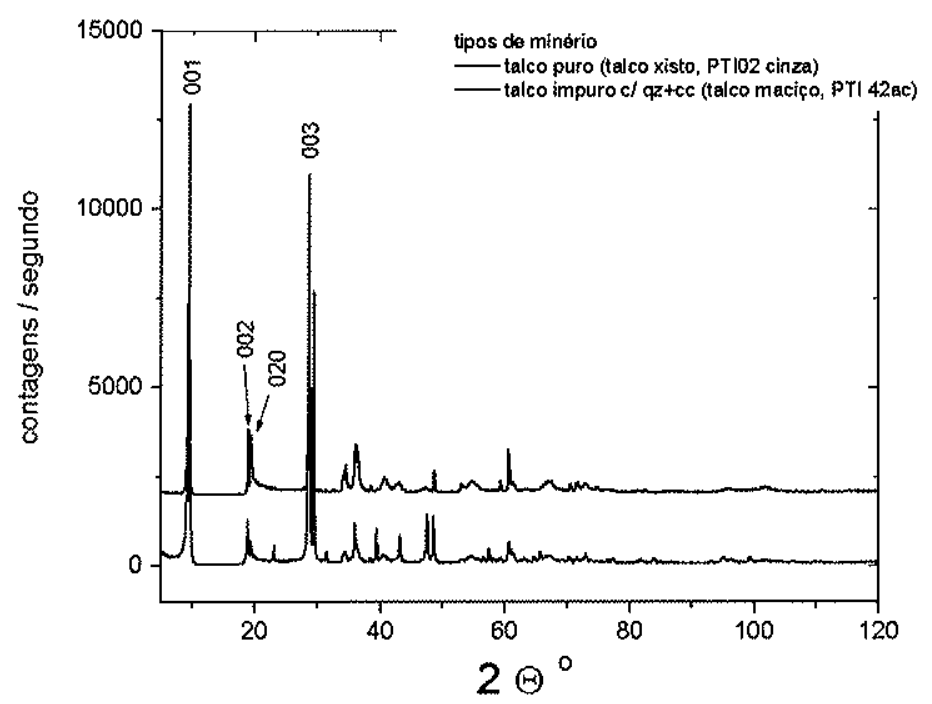

Figura 21. Difratogramas de raios $\mathrm{X}$ de amostras de talco de talco xisto e de talco maciço fino. A escala absoluta de intensidade consta apenas por referência e foi alterada para permitir a melhor comparação das amostras. As amostras foram desagregadas por via úmida.

O método de análise de dados difratométricos proposto por Hugo Rietveld (1969) é um procedimento baseado na comparação entre o difratograma medido na amostra e um difratograma calculado a partir de um modelo teórico que considera as fases cristalinas presentes na amostra e as condições analíticas usadas na aquisição dos dados. O difratograma calculado é refinado em iterações sucessivas, para se chegar à menor soma possível dos quadrados das diferenças entre ele e o difratograma real da amostra. No refinamento é considerada a radiação de fundo (background) e variáveis que afetam a intensidade dos picos, sua largura e assimetria, como orientação preferencial das fases cristalinas, microdeformação estrutural das fases, rugosidade da amostra, entre outros. Quando o refinamento do difratograma calculado atingiu uma convergência considerada aceitável por parâmetros estatísticos, podemo obter as proporções de fases presentes na amostra, bem como informações sobre aspectos estruturais de cada uma destas fases.

Estão disponíveis na literatura três modelos de estrutura para o talco (Gruner, 1934; Rayner e Brown, 1973; Perdikatsis e Burzlaff, 1981), entretanto nenhum deles permitiu uma convergência adequada por critérios estatísticos com as amostras analisadas de talco do Grupo Itaiacoca. O teste destes três modelos de estruturas foi 
feito com uma amostras de referência (PTI02 cinza), tendo sido realizados os mesmos passos de refinamento pelo método de Rietveld, que foram: (1) modelagem de ruído de fundo (background), com polinômio de Chebyshev modificado de grau 8 ; (2) fator de escala; (3) correção de deslocamento (shift) de picos; (4) refinamento de parâmetros de cela $(a, b, c, \alpha, \beta, \gamma)$; (5) correção de orientação preferencial (modelo March-Dollase) para os planos 001 ; (6) parâmetros de perfil de pico, considerando suas componentes lorentzianas (LX) e gaussianas (GU, GW, GP); (7) parâmetros instrumentais de assimetria de pico. Após estes passos de refinamento, nenhuma das três estruturas disponíveis permitiu uma convergência satisfatória (Figura 22). Os gráficos de Rietveld são construídos de uma forma padronizada, sobrepondo o difratograma observado (amostra real) e o difratograma calculado a partir do modelo de estrutura e apresentando abaixo a diferença entre ambos ponto a ponto (as análises foram feitas entre 5 e $120^{\circ} 2$ teta com passo de $0,02^{\circ}$, totalizando 5750 posições angulares de medição).

Dentre os parâmetros estatísticos utilizados para avaliar a convergência do modelo calculado em direção ao dado real, escolhemos o $\chi^{2}\left(\mathrm{CHI}^{2}\right.$ ou goodness of fit $)$ que representa a razão entre o resíduo ponderado e o resíduo estatiscamente esperado como mínimo $\left(\chi^{2}=R_{\mathrm{wp}} / \mathrm{R}_{\mathrm{exp}}\right)$. Num refinamento bem sucedido, o valor de $\chi^{2}$ deve ser $\leq 2$, indicando que as possibilidades de refinamento do modelo calculado foram esgotadas e que se está próximo do resíduo mínimo estatístico esperado. Nos testes realizados com as três estruturas disponíveis (Figura 22), os valores de $\chi^{2}$ atingiram mais de dez vezes acima do máximo, em torno de 25 para as estruturas propostas por (Rayner e Brown (1973) e Perdikatsis e Burzlaff (1981), e acima de 40 para a estrutura proposta por Gruner (1934). Estes valores indicam a impossibilidade de convergência entre os dados reais e modelos de estruturas da literatura. Uma tentativa de reduzir este resíduo foi feita através do refinamento dos parâmetros de deslocamento atômico isotrópico $\left(\mathrm{U}_{\mathrm{iso}}\right)$ para cada caso. Apesar de ter havido redução de $\chi^{2}$, em todos os três casos os valores obtidos no refinamento foram negativos para algumas posições atômicas, o que não tem sentido físico, pois indicaria uma amplitude negativa de vibração térmica destes átomos no retículo. 


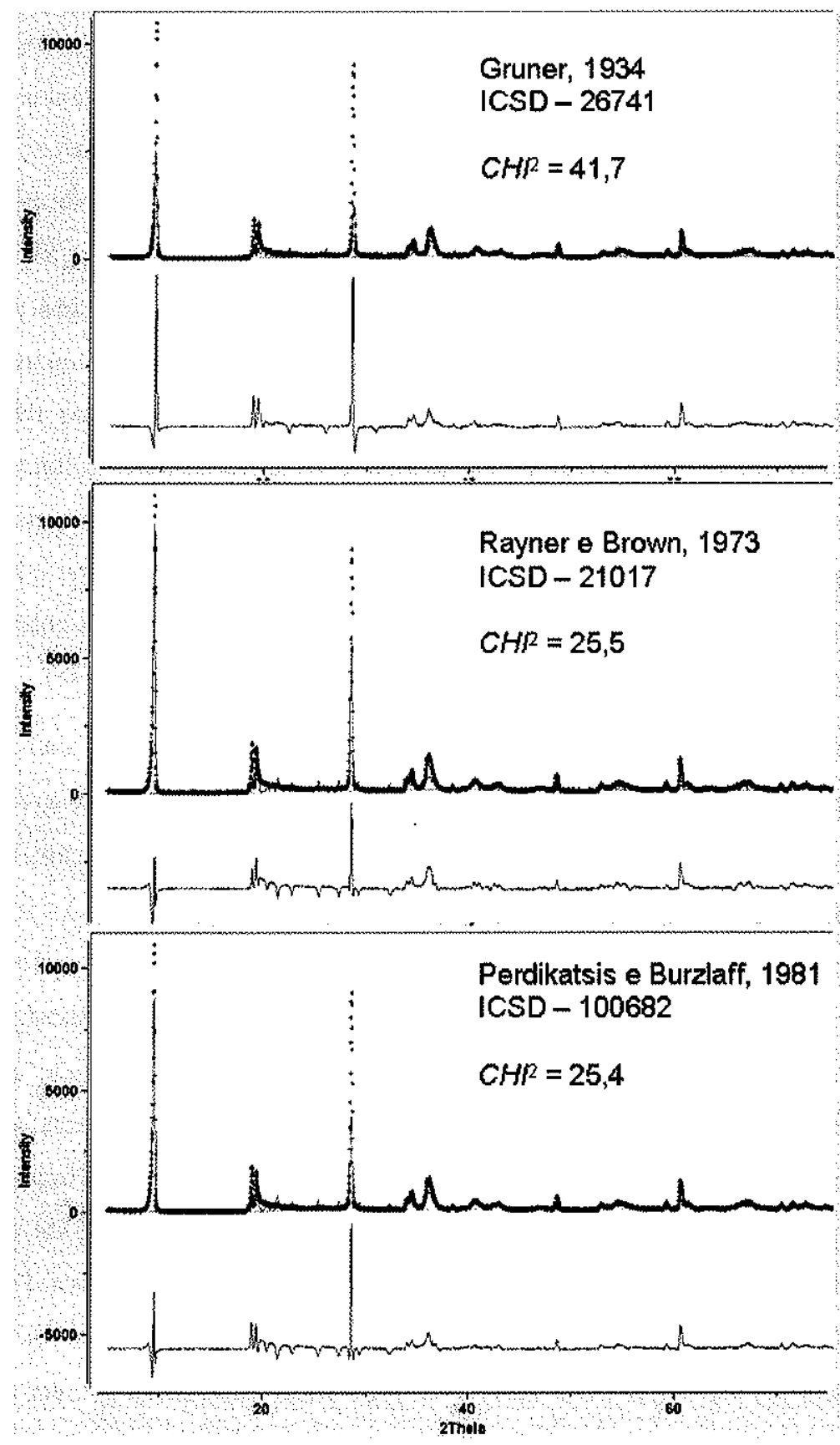

Figura 22. Gráficos de Rietveld com comparação entre modelos de estruturas. 


\subsection{Microscopia eletrônica de varredura}

A microscopia eletrônica de varredura mostrou um quadro de maior detalhe dos tipos de talco do Grupo Itaiacoca. Imagens de elétrons retroespalhado em seções polidas (Figura 23) de talco xistos com tremolita e com fragmentos de metadolomito, revelam que os domínios com talco foram afetados pela deformação, indicando que esta continuou ocorrendo durante a após a talcificação; nesta amostra, a calcita preenche vênulas concordantes com a foliação (Figura 23a). Em um metadolomito cisalhado e incipientemente talcificado, o talco define uma foliação anastomosada, juntamente com a tremolita, e observa-se a formação de manchas de calcita sobre a dolomita original, possivelmente refletindo o liberação de cálcio da dolomita durante a talcificação (Figura 23b). No caso do metadolomito que contém talco do tipo maciço fino, a mineralização ocorre na intersecção de fraturas onde se concentra a calcita hidrotermal macrocristalina, envolta por associação de talco e calcita microcristalinos (Figura 23c). No mármore dolomítico no contato com o granito, a dolomita assume textura granoblástica e há presença de cristais aciculares de tremolita bordejados por calcita; neste contexto, o talco é visto no preenchimento de pseudomorfos nas extremidades de um prisma de tremolita (Figura 23d).

Amostras de minérios de talco xisto de alta pureza (Mina Paranaense, PTI 02 AQ2) apresentam granulação homogênea, após moagem a quente. Neste caso não foram observados minerais fibrosos, ainda que em algumas seções perpendiculares ao eixo $c$ as clivagens basais dão a falsa impressão de hábito fibroso (Figura 24 a,b). Em amostra de minério contaminado com tremolita fibrosa (Mina Pocinhos, PTI 09 AA1), observase a presença de fibras retilíneas, aciculares, além da presença de quartzo (Figura $24 \mathrm{c}, \mathrm{d})$. 

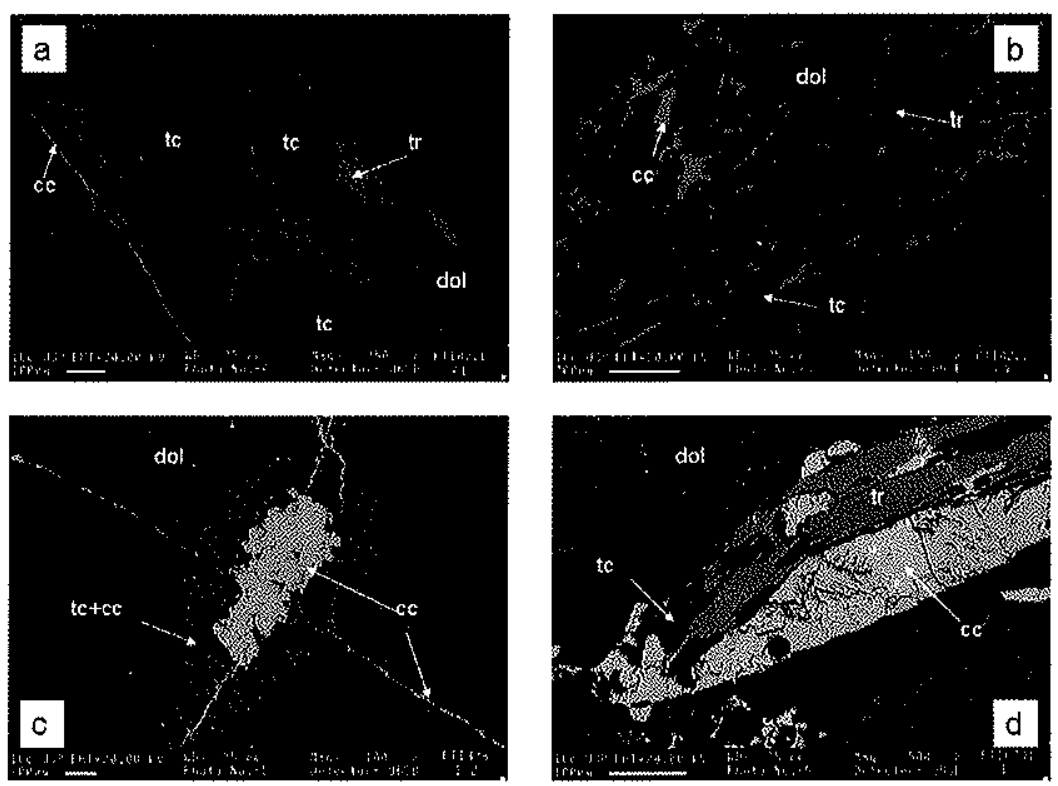

Figura 23. Imagens de elétrons retroespalhados obtidas por microscopia eletrônica de varredura. (a) talco xisto com tremolita (PTI22L); (b) talco xisto com tremolita (PTI22L); (c) talco maciço fino em intersecção de fraturas (PTI42A); (d) tremolita mármore dolomítico, com talco retrometamórfico (PTI07JI) $($ dol = dolomita; $c c=$ calcita; tc $=$ talco; tr = tremolita).
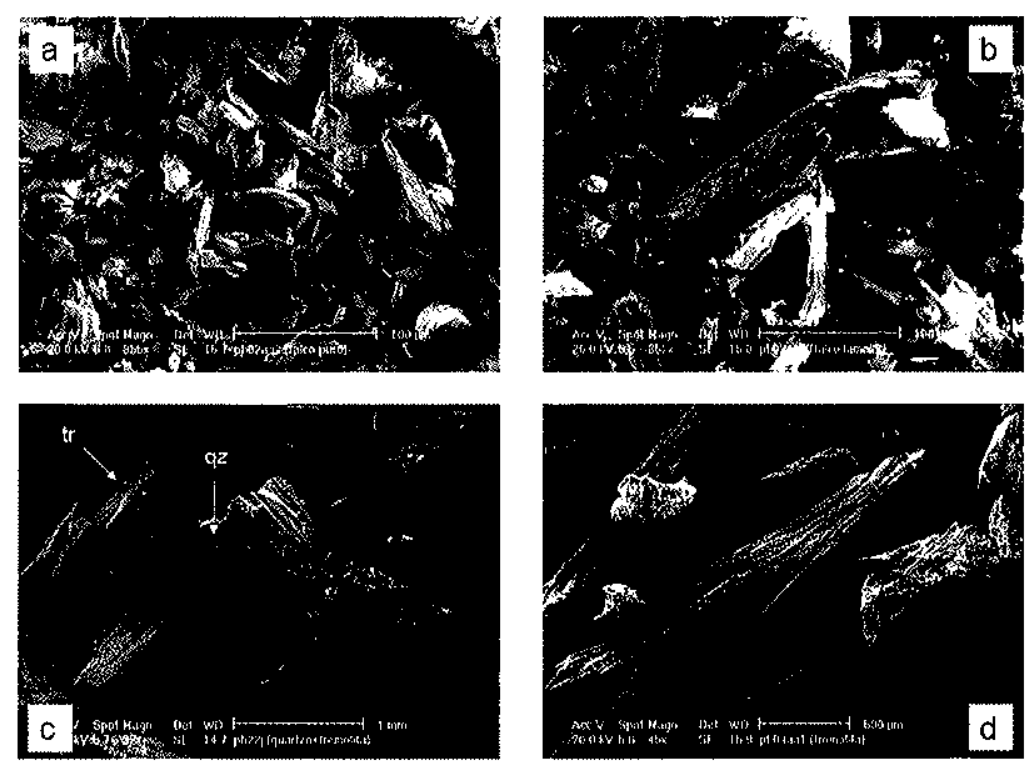

Figura 24. Imagens de elétrons secundários obtidas por microscopia eletrônica de varredura. (a) minério de talco puro (PTI02AQ2); (b) talco lamelar em detalhe (PTI02AQ2); (c) associação tremolita+quartzo (PTI22J); (d) tremolita fibrosa em detalhe (PTI09AA1) (cc = calcita; $t c=$ talco; $t r=$ tremolita; $\mathrm{qz}=$ quartzo). 


\subsection{Geoquímica de rocha total}

Os resultados das análises geoquímicas de rocha total são apresentados na Tabela 6. As amostras analisadas incluem metadolomitos originais, incipientemente talcificados, talco xistos, minério de talco maciço fino e mármores dolomíticos com tremolita no contato com granito. No gráfico $\mathrm{CaO}-\mathrm{MgO}-\mathrm{SiO}_{2}$ (proporção molar), os metadolomitos originais e os incipientemente talcificados apresentam uma variação ampla de $\mathrm{SiO}_{2}$ (Figura 25a), mantendo a razão $\mathrm{CaO}: \mathrm{MgO}$ constante. Parte desta sílica é devida à presença de quartzo detrítico e parte a veios hidrotermais de quartzo e pequenas proporções de talco. Os talco xistos mostram uma tendência distinta, com progressiva diminuição de $\mathrm{CaO}$ em direação aos minérios de talco mais puros, mas mantendo a razão $\mathrm{SiO}_{2}: \mathrm{MgO}$ constante (Figura 25b). As amostras analisadas de talco maciço fino contêm praticamente apenas talco e teores subordinados de quartzo, e se localizam próximo à posição estequiométrica do talco no diagrama triagular (Figura 25c). O mármore dolomítico no contato com o Complexo Granítico Cunhaporanga situa-se no mesmo campo dos metadolomitos originais pobres em sílica (Figura 25d), indicando que não houve expressiva entrada e saída de elementos neste processo.

A mobilidade de elementos foi quase total nos casos em que a talcificação se processou até atingir a transformação completa do metadolomito em talco. Foi construído um diagrama com elementos maiores, enxofre e estrôncio, normalizados por uma amostra de metadolomito original de referência (Figura 26); dentre as metadolomitos originais com estruturas sedimentars preservadas, foi escolhida como referência a amostra com menor teor de sílica (amostra PTI01A, Tabela 6). A sílica nas amostras de metadolomitos originais é via de regra baixa, mas pode atingir valores excepcionalmente elevados em casos raros e localizados (15 a 33\%peso) - nestes casos a sílica não está vinculada à talcificação, mas sim à presença de grãos de quartzo detrítico e veios de quartzo. No conjunto de amostras talcificadas (talcificação incipiente, talco xisto, talco maciço fino) há um enriquecimento em sílica devido à alteração hidrotermal, concomitante com perda de $\mathrm{Ca}$ e $\mathrm{CO}_{2}$, até abaixo do limite de detecção dos métodos analíticos utilizados. Apesar de se perceber relativo aumento de $\mathrm{Al}_{2} \mathrm{O}_{3}$ e $\mathrm{FeO}_{\text {total }}$, os teores absolutos são bastante reduzidos. Os elementos traços plotados neste gráfico não mostraram tendências significativas de variação. Confirmando o observado na Figura 25, os mármores dolomíticos apresentam praticamente a mesma composição elemental dos metadolomitos originais. 

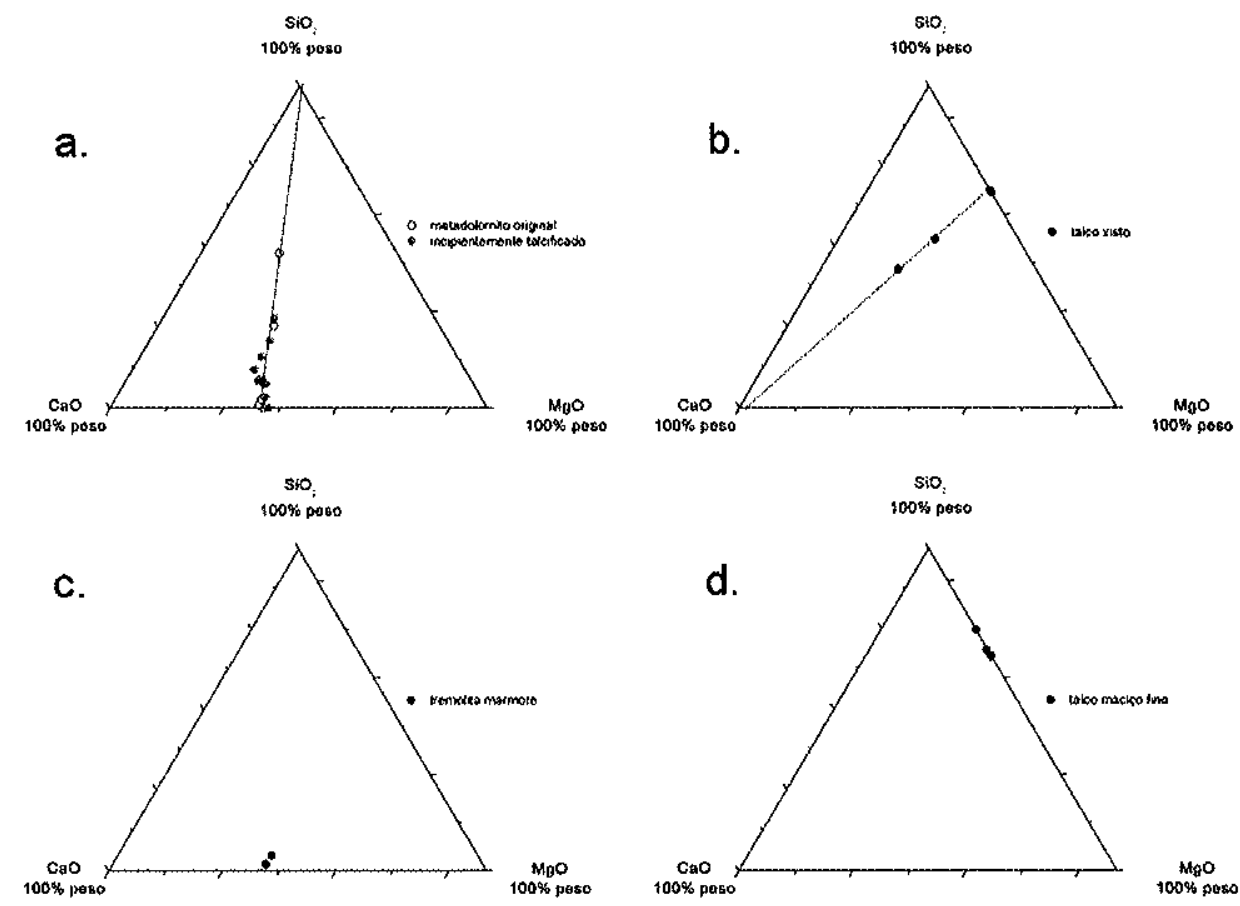

Figura 25. Composição química de rocha total, diagramas triangulares $\mathrm{CaO}-\mathrm{MgO}-\mathrm{SiO}_{2}$ (proporção molar).

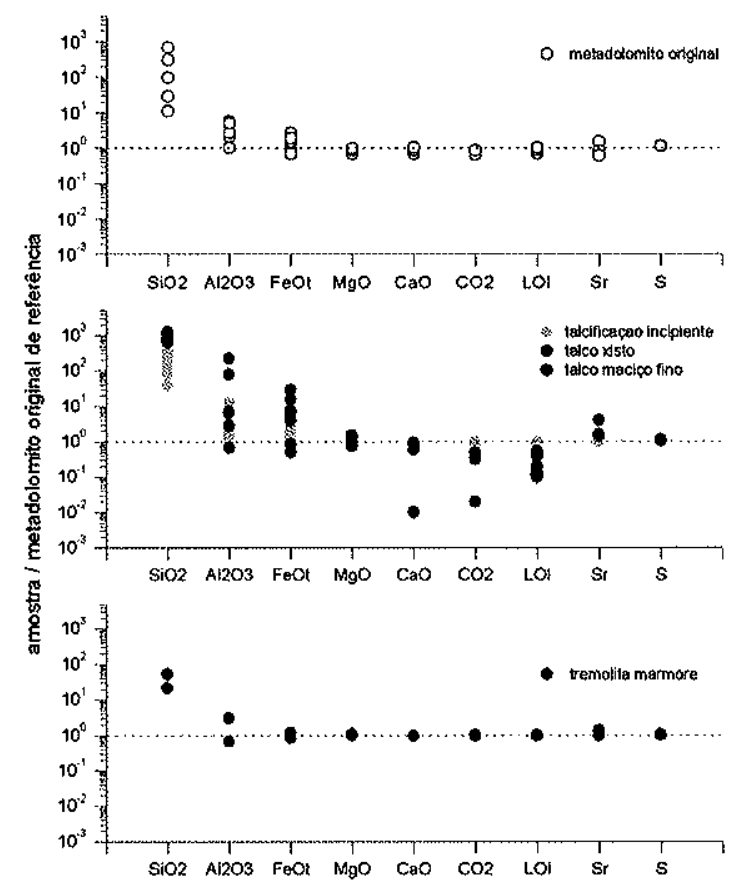

Figura 26. Composição química de rocha total, diagramas multielementos normalizados por metadolomito original com baixa sílica (amostra PTI1A, Tabela 6). 
Tabela 6. Dados geoquímicos de rocha total.

\begin{tabular}{|c|c|c|c|c|c|c|c|c|c|c|c|c|c|c|c|}
\hline \multirow[b]{2}{*}{ Amostra } & \multicolumn{6}{|c|}{ metadolomito original (não talcificado) } & \multicolumn{9}{|c|}{ metadolomito incipientemente talcificado } \\
\hline & PTI0lA & PTI15B & PT137AA & PTI39A & PTI48 & PTI54A1 & PT105D & PT106B & PTIO6D1 & PT106D2 & PT106E & PTI22C & PT122D2 & PT122L & PT135C \\
\hline $\mathrm{SiO}_{2}[\%]$ & 0,05 & 33,2 & 4,85 & 15,3 & 0,53 & 1,43 & 0 & 4,21 & 13,1 & 1,95 & 19,1 & 9,5 & 6,93 & 5,17 & 4,77 \\
\hline $\mathrm{TiO}_{2}$ & $<0,01$ & $<0,01$ & $<0,01$ & $<0,01$ & $<0,01$ & $<0,01$ & $<0,01$ & $<0,01$ & $<0,01$ & $<0,01$ & $<0,01$ & $<0,01$ & $<0,01$ & $<0,01$ & 0,03 \\
\hline $\mathrm{Al}_{2} \mathrm{O}_{3}$ & 0,06 & 0,12 & 0,16 & 0,33 & 0,06 & 0,29 & 0,07 & 0,1 & 0,07 & 0,08 & 0,09 & 0,34 & 0,14 & 0,15 & 0,77 \\
\hline $\mathrm{FeO}_{\mathrm{t}}$ & 0,06 & 0,05 & 0,09 & 0,16 & 0,04 & 0,11 & 0,1 & 0,08 & 0,05 & 0,05 & 0,05 & 0,14 & 0,1 & 0,12 & 0,29 \\
\hline $\mathrm{MnO}$ & 0,01 & $<0,01$ & $<0,01$ & $<0,01$ & $<0,01$ & $<0,01$ & $<0,01$ & $<0,01$ & $<0,01$ & $<0,01$ & 1,27 & $<0,01$ & $<0,01$ & $<0,01$ & $<0,01$ \\
\hline $\mathrm{MgO}$ & 21,5 & 14,4 & 20,8 & 18,5 & 21 & 20,8 & 22,8 & 21,3 & 20,1 & 22,1 & 20,1 & 19,3 & 18,8 & 20,2 & 20,0 \\
\hline $\mathrm{CaO}$ & 31,4 & 21,7 & 31,9 & 26,4 & 32,5 & 31,4 & 31,4 & 31,0 & 29,6 & 32,0 & 29,0 & 31,1 & 32,5 & 31,91 & 32,2 \\
\hline $\mathrm{Na}_{2} \mathrm{O}$ & $<0,01$ & $<0,01$ & 0,05 & $<0,01$ & 0,02 & 0,04 & $<0,01$ & $<0,01$ & $<0,01$ & $<0,01$ & $<0,01$ & $<0,01$ & $<0,01$ & $<0,01$ & $<0,01$ \\
\hline $\mathrm{K}_{2} \mathrm{O}$ & $<0,03$ & $<0,03$ & $<0,03$ & 0,11 & $<0,03$ & $<0,03$ & $<0,03$ & $<0,03$ & $<0,03$ & $<0,03$ & $<0,03$ & $<0,03$ & $<0,03$ & $<0,03$ & 0,08 \\
\hline $\mathrm{P}_{2} \mathrm{O}_{5}$ & 0,01 & 0,01 & 0,01 & 0,01 & 0,07 & $<0,01$ & 0,01 & $<0,01$ & $<0,01$ & $<0,01$ & $<0,01$ & 0,01 & 0,01 & 0,01 & 0,01 \\
\hline $\mathrm{H}_{2} \mathrm{O}+$ & 0,08 & 0,09 & n.d. & 0,04 & n.d. & n.d. & 0,02 & 0,44 & 0,32 & n.d. & 1,27 & 0,54 & 0,54 & 0,71 & 1,13 \\
\hline $\mathrm{CO}_{2}$ & 46,9 & 30,4 & n.d. & 39,1 & n.d. & n.d. & 45,3 & 43,2 & 37 & 44,1 & 30,5 & 39,0 & 41,0 & 41,9 & 41,3 \\
\hline LOI & 46,6 & 31,0 & 43,0 & 40,06 & 46,6 & 46,1 & 45,5 & 44,0 & 37,1 & 44,5 & 32,1 & 40,0 & 41,8 & 42,6 & 42,6 \\
\hline Total & 99,7 & 100,5 & 100,9 & 100,9 & 100,8 & 100,2 & 99,9 & 100,7 & 100,0 & 100,7 & 101,7 & 100.5 & 100,3 & 100,2 & 100,8 \\
\hline $\mathrm{Ba}$ [ppm] & $<10$ & $<10$ & $<10$ & $<10$ & $<10$ & $<10$ & $<10$ & $<10$ & $<10$ & $<10$ & $<10$ & 11 & 9 & 11 & $<10$ \\
\hline $\mathrm{Sr}$ & 27 & 21 & 39 & 41 & 22 & 16 & 42 & 26 & 30 & 26 & 36 & 32 & 32 & 31 & 49 \\
\hline $\mathrm{v}$ & $<15$ & $<15$ & $<15$ & $<15$ & $<15$ & $<15$ & $<15$ & $<15$ & $<15$ & $<15$ & $<15$ & $<15$ & $<15$ & $<15$ & $<15$ \\
\hline$Y$ & $<10$ & $<10$ & $<10$ & $<10$ & $<10$ & $<10$ & $<10$ & $<10$ & $<10$ & $<10$ & $<10$ & $<10$ & $<10$ & $<10$ & $<10$ \\
\hline $\mathrm{Zr}$ & $<25$ & $<25$ & $<25$ & $<25$ & $<25$ & $<25$ & $<25$ & $<25$ & $<25$ & $<25$ & $<25$ & $<25$ & $<25$ & $<25$ & $<25$ \\
\hline$S$ & 275 & 322 & n.d. & 300 & n.d. & n.d. & 301 & 284 & 313 & 324 & 320 & 329 & 314 & 304 & 306 \\
\hline
\end{tabular}


Tabela 6. (continuação).

\begin{tabular}{|c|c|c|c|c|c|c|c|c|c|}
\hline \multirow[b]{2}{*}{ Amostra } & \multicolumn{4}{|c|}{ talco xisto } & \multicolumn{3}{|c|}{ talco fino maciço } & \multicolumn{2}{|c|}{ tremolita mármore } \\
\hline & PTro2G & PTT22F & PTI02B & PTI08AB2 & PTI46E & PTI46F & PTI46G & PTI05B & PTI47A \\
\hline $\mathrm{SiO}_{2}[\%]$ & 42,9 & 32,6 & 64,2 & 62,9 & 57,6 & 62,6 & 60,0 & 2,62 & 1,08 \\
\hline $\mathrm{TiO}_{2}$ & $<0,01$ & $<0,01$ & $<0,01$ & 0,02 & 0,26 & 0,02 & 0,18 & $<0,01$ & $<0,01$ \\
\hline $\mathrm{Al}_{2} \mathrm{O}_{3}$ & 0,04 & 0,17 & 0,04 & 0,42 & 13,3 & 0,39 & 4,7 & 0,18 & 0,04 \\
\hline $\mathrm{FeO}_{\mathrm{t}}$ & 0,05 & 0,24 & 0,03 & 0,45 & 1,77 & 0,32 & 0,93 & 0,07 & 0,05 \\
\hline $\mathrm{MnO}$ & $<0,01$ & $<0,01$ & $<0,01$ & 0,03 & 0,04 & 0,02 & 0,01 & $<0,01$ & $<0,01$ \\
\hline $\mathrm{MgO}$ & 21,1 & 15,7 & 31,0 & 31,5 & 19,6 & 31,5 & 27,3 & 22,5 & 21,3 \\
\hline $\mathrm{CaO}$ & 18,4 & 28,0 & $<0,01$ & 0,02 & $<0,006$ & 0,02 & 0,31 & 30,2 & 30,12 \\
\hline $\mathrm{Na}_{2} \mathrm{O}$ & $<0,01$ & 0,04 & $<0,01$ & 0,03 & 0,03 & 0,03 & 0,11 & $<0,01$ & $<0,01$ \\
\hline $\mathrm{K}_{2} \mathrm{O}$ & $<0,03$ & $<0,03$ & $<0,03$ & $<0,03$ & 0,05 & $<0,03$ & 1,14 & $<0,03$ & $<0,03$ \\
\hline $\mathrm{P}_{2} \mathrm{O}_{5}$ & 0,01 & 0,01 & 0,01 & $<0,01$ & 0,01 & $<0,01$ & 0,03 & 0,01 & $<0,01$ \\
\hline $\mathrm{H}_{2} \mathrm{O}+$ & 2.38 & 1,82 & 4,28 & n.d. & n.d. & n.d. & n.d. & 0,33 & n.. $\bar{d}$ \\
\hline $\mathrm{CO}_{2}$ & 15,2 & 22,1 & 0,82 & n.d. & n.d. & n.d. & n.d. & 44,2 & 46,8 \\
\hline LOI & 18,3 & 24,2 & 4,8 & 5,16 & 8,74 & 5,24 & 6,21 & 44,4 & 46,9 \\
\hline Total & 100,7 & 100,9 & 100 & 100,4 & 101,3 & 100,1 & 100,9 & 99,9 & 99.5 \\
\hline $\mathrm{Ba}$ [ppm] & $<10$ & 11 & $<10$ & $<10$ & 46 & 17 & 37 & $<10$ & $<10$ \\
\hline $\mathrm{Sr}$ & 111 & 41 & $<5$ & $<5$ & $<5$ & $<5$ & $<5$ & 37 & 26 \\
\hline $\mathrm{v}$ & $<15$ & $<15$ & $<15$ & $<15$ & 18 & $<15$ & 32 & $<15$ & $<15$ \\
\hline Y & $<10$ & $<10$ & $<10$ & $<10$ & 28 & $<10$ & 102 & $<10$ & $<10$ \\
\hline $\mathrm{Zr}$ & $<25$ & $<25$ & $<25$ & $<25$ & 41 & $<25$ & 38 & $<25$ & $<25$ \\
\hline$S$ & 317 & 305 & 294 & n.d. & n.d. & n.d. & n.d. & 290 & 272 \\
\hline
\end{tabular}




\subsection{Química mineral}

Foram realizadas análises químicas dos minerais dolomita, calcita, talco, clorita, serpentina, tremolita e diopsídio, que são as principais fases minerais ligados ao metamorfismo e à talcificação dos metadolomitos do Grupo Itaiacoca. De modo geral, todas as fases analisadas têm composição pura, próximas dos membros finais magnesianos de suas respectivas séries. Os dados completos de cada mineral são apresentados em tabelas em anexos ao final do trabalho.

\subsubsection{Carbonatos}

Os carbonatos presentes nos metadolomitos são dolomita e calcita, ambos praticamente desprovidos de ferro, e com os elementos traços $\mathrm{Sr}, \mathrm{Ba}, \mathrm{Sr}, \mathrm{Zn}$ abaixo do limite de detecção da microssonda eletrônica, tanto em dolomita (Anexo Tabela A-1) como em calcita (Anexo Tabela A-2). O elemento Mn chega a ocorrer em valores da ordem de milésimos de átomos por fórmula unitária (a.p.f.u.). A calcita foi a fase mais sistematicamente analisada, devido ao seu potencial geotermométrico. As análises de dolomita se mostraram problemáticas, a maioria com fechamento inferior a $97 \%$. Os minerais magnesianos em geral apresentam fechamento baixo, provavelmente em razão da baixa massa atômica do $\mathrm{Mg}$ causar um efeito matriz não adequadamente previsto nas correções empregadas. Ambas as fases são desprovidas de ferro (Figura 27a), e suas composições indicam excesso de $\mathrm{Mg}$ na calcita e excesso de $\mathrm{Ca}$ na dolomita (Figura 27b). Apesar da faixa de variação de teor em ambos os casos ser pequena, os carbonatos de talco xisto apresentam uma faixa de variação composicional maior que a dos carbonatos em talco maciço fino. A calcita presente no mármore dolomítico na auréola de contato com o granito apresenta os maiores teores de $\mathrm{Mg}$, o que é decorrência de uma temperatura de cristalização elevada, como será discutido oportunamente. Cabe ressaltar que as razões $\mathrm{Ca}: \mathrm{Mg}$ apresentam expressiva variação entre cristais vizinhos em uma mesma amostra, bem como dentro de um mesmo cristal. As análises por microscopia eletrônica de varredura revelaram a ausência de lamelas de exsolução tanto em calcita como em dolomita (Figura 23), indicando que a heterogeneidade composicional é dada por desequilíbrios locais sem controle estrutural definido. 

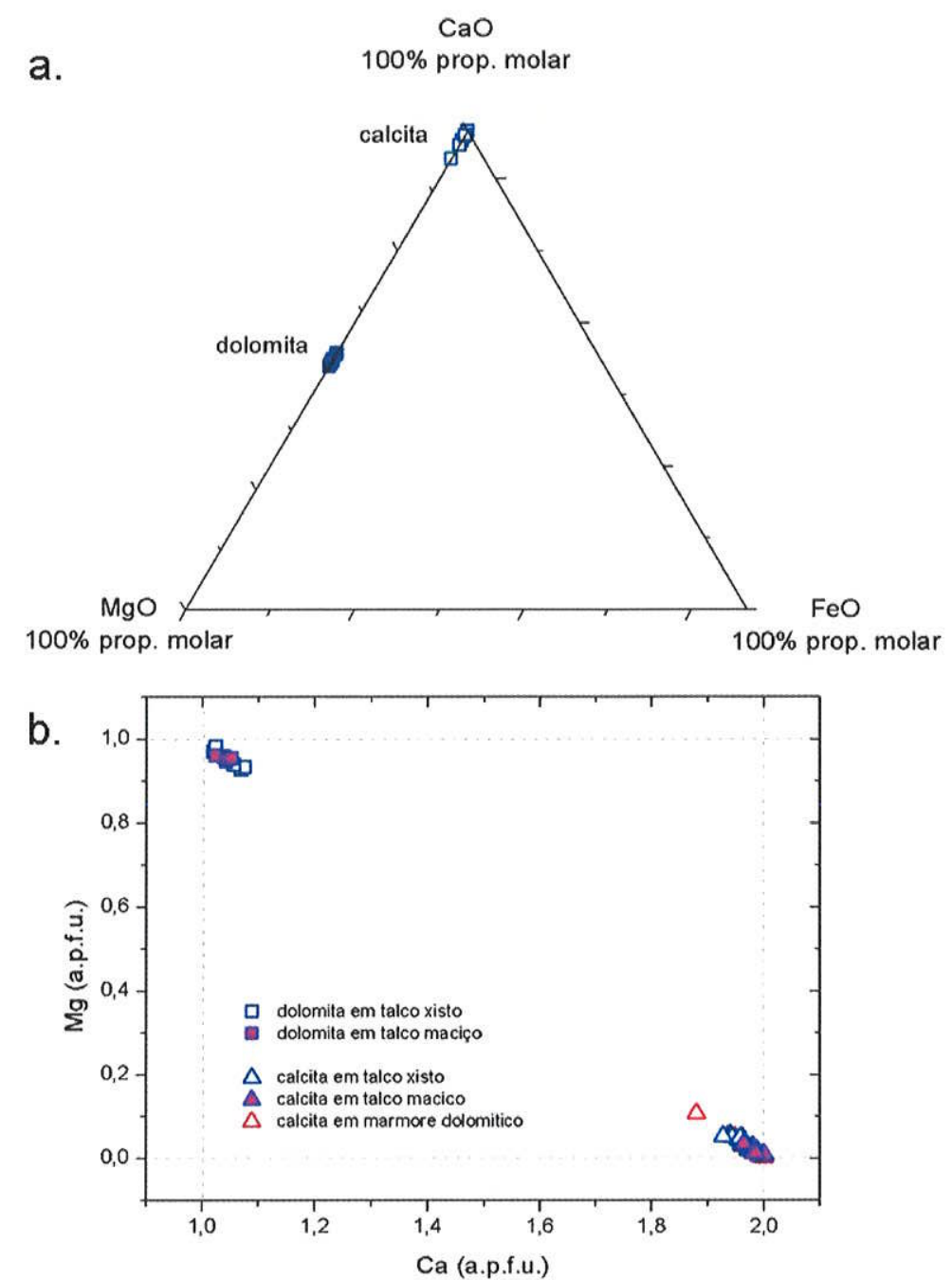

Figura 27. Composição de calcita e dolomita. (a) diagrama triangular $\mathrm{CaO}-\mathrm{MgO}-\mathrm{FeO}$ (propr. molares); (b) diagrama Ca versus $\mathrm{Mg}$ (a.p.f.u.) das mesmas amostras.

\subsubsection{Talco}

O talco foi analisado apenas em amostras nas quais com cristais bem desenvolvidos, incluindo em talco xistos das zonas de cisalhamento, em talco maciço fino e em talco em fraturas, presente em metadolomitos incipientemente talcificados (Anexo Tabela A-3). A única variação composicional percebida nas amostras de talco analisadas é a substituição de uma pequena fração de Si por Al. As relações entre Si e $\mathrm{Al}$ total $\left(\mathrm{Al}^{\mathrm{IV}}+\mathrm{Al}^{\mathrm{VI}}\right)$ (Figura 28$)$ revelam diferenças entre o talco contido nos três tipos 
de amostras analisadas: (a) o talco em talco xisto apresenta os mais elevados valores de $\mathrm{Al}$ até 0,5 a.p.f.u.; (b) o talco do minério de talco maciço fino apresenta tendência semelhante, mas $\mathrm{Al}<0,15$ a.p.f.u.; (c) o talco presente em fraturas em metadolomito incipientemente talcificado apresenta tendência distinta, sendo praticamente isento de Al e apresentando pequeno excesso de $\mathrm{Si}$ com até 8,05 no sítio tetraédrico, correspondendo este excesso a erro analítico.

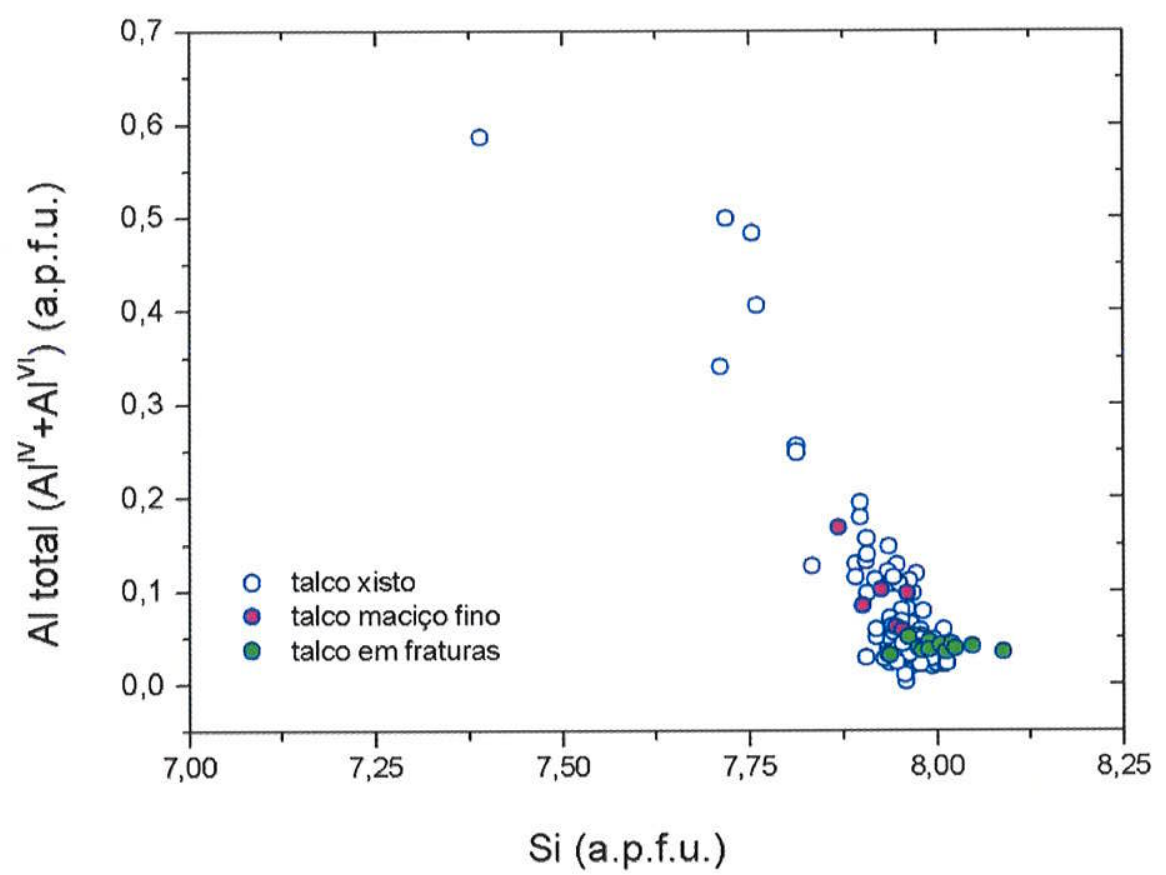

Figura 28. Variação composicional de talco, Si versus $\mathrm{Al}$ (a.p.f.u.).

\subsubsection{Clorita e serpentina}

Os minerais clorita e serpentina ocorrem associados ao talco em pequenas quantidades em talco xisto em zonas de cisalhamento. Os dados químicos completos estão nos Anexos Tabela A-4 e A-5, respectivamente. Ambas as fases apresentam sítios tetraédricos ocupados praticamente apenas por $\mathrm{Si}$ e os sítios octaédricos ocupados por $\mathrm{Mg}$ em quase sua totalidade. A clorita apresenta composição do extremo magnesiano clinocloro; alguns pontos analisados têm excesso de Si no sítio tetraédrico da ordem de 8,1 a.p.f.u. devido a erro analítico, $\mathrm{Mg}$ entre 9,8 e 10 a.p.f.u., e Fe reduzidas $<0,02$ 
a.p.f.u., sendo negligenciáveis os teores dos demais cátions analisados ( $\mathrm{Ti}, \mathrm{Cr}, \mathrm{Mn}, \mathrm{Ni})$. Praticamente o mesmo padrão se repete na serpentina, cuja variedade presente nos talco xistos é fibrosa, crisotila.

\subsubsection{Tremolita}

O anfibólio presente nas rochas carbonáticas do Grupo Itaiacoca é a tremolita (Anexo Tabela A-6), predominantemente na variedade fibrosa, mas também na forma de prismas curtos. As amostras analisadas são provenientes de duas situações: (i) em talco xistos nas zonas de cisalhamento, cuja ocorrência é rara; e (ii) em tremolita mármores dolomíticos da zona de contato com o Complexo Granítico Cunhaporanga, onde é o mais abundante mineral índice preservado de metamorfismo de contato. Há diferença nas ocupações catiônicas na tremolita destes dois casos. A tremolita do mármore apresenta $\mathrm{Al}$ total $\left(\mathrm{Al}^{\mathrm{IV}}+\mathrm{Al}^{\mathrm{Vl}}\right)$ significativamente mais elevado $(>0,3$ a.p.f.u.) que na tremolita de talco xisto ( $<0,3$ a.p.f.u.) (Figura 29). $O$ mesmo se aplica à relação entre $\mathrm{Mg}$ e Fe: a tremolita no talco xisto é isenta de Fe e no mármore em contato com o granito apresenta até 0,025 a.p.f.u. de Fe. A tremolita dos mármores dolomíticos do Grupo Itaiacoca no contato com o Complexo Granítico Três Córregos apresenta valores mais elevados de $\mathrm{Na}+\mathrm{K}$ (até 0,15 a.p.f.u.), enquanto na tremolita de talco xisto o conteúdo de $\mathrm{Na}+\mathrm{K}$ (A) é $<0,13$ a.p.f.u. Nas amostras associadas a rochas carbonáticas ou de protólito carbonático, o anfibólio é tremolita s.s., com razões $\mathrm{Mg} /(\mathrm{Mg}+\mathrm{Fe})$ entre 0,95 e 1,00. A diferença no padrão de variação composicional de anfibólios entre amostras de mármore dolomítico e mesmo internamente às amostras da zona de contato sugere diferenças composicionais dos fluidos envolvidos na formação destes minerais. 


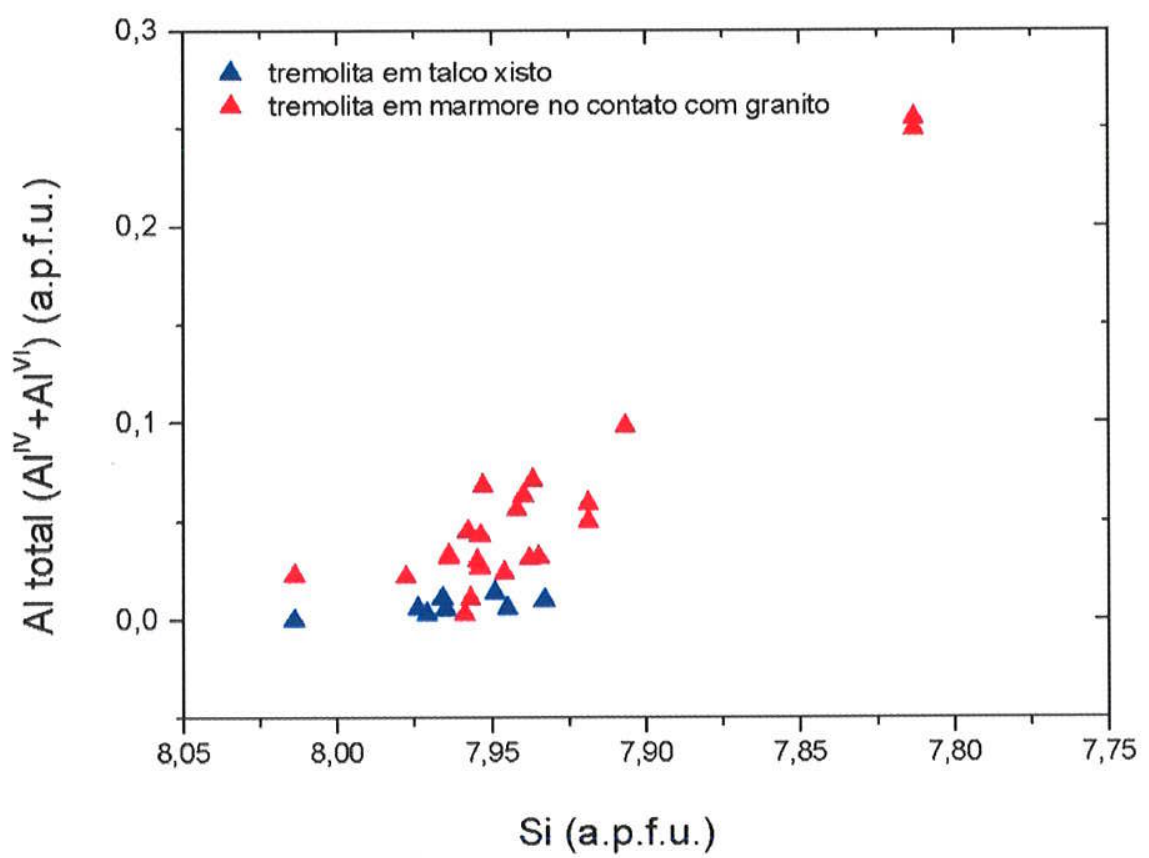

Figura 29. Variação composicional de tremolita de talco xisto e de mármore dolomítico, $\mathrm{Si}$ versus $\mathrm{Al}$ (a.p.f.u.).

\subsubsection{Diopsídio}

O piroxênio está presente apenas nas auréolas de contato entre metadolomito (mármore dolomítico) e o Complexo Granítico Cunhaporanga, concentrado em domínios lenticulares. Todos os pontos analisados são, portanto, do mesmo contexto geológico e os dados completos encontram-se no Anexo Tabela A-7. O piroxênio em questão é um diopsídio praticamente puro, na composição do extremo magnesiano da série dos clinopiroxênios.

\subsection{Isótopos estáveis de carbono e oxigênio}

Os dados de isótopos estáveis de carbono e oxigênio de carbonatos do Grupo Itaiacoca são apresentados na Tabela 7. As amostras abrangem as seguintes categorias, de acordo com o contexto geológico ou petrográfico em que ocorrem:

- dolomita e calcita em metadolomito original (apenas metamorfismo regional); 
- dolomita e calcita em metadolomito brechado (clastos e matriz),

- dolomita e calcita de metadolomito talcificado;

- dolomita de metadolomito no contato com granito;

- dolomita e calcita de metadolomito no contato com diabásio;

- calcita e aragonita em crostas supergênicas.

Para facilitar a consulta, os intervalos de razões isotópicas de dolomita e calcita de cada tipo litológico acima estão organizados na Tabela 8. Os metadolomitos originais, que preservam suas estruturas sedimentares primárias e não foram afetadas por eventos posteriores ao metamorfismo regional, apresentam os valores mais elevados de $\delta \mathrm{O}$ e $\delta \mathrm{C}$, sendo que todos os demais grupo apresentam redução de $\delta \mathrm{O}$ ou $\delta \mathrm{C}$ ou ambos (Figura 30). Observa-se uma variação sistemática das razões isotópicas de carbono e oxigênio de acordo com os processos geológicos superimpostos ao metamorfismo regional de baixo grau que afetou todo o Grupo Itaiacoca. Os metadolomitos relacionados à talcificação, incluindo carbonatos em talco xistos, brechas, rochas venuladas e talcificadas, apresentam um desvio para valores menores de $\delta \mathrm{O}$, mantendo $\delta \mathrm{C}$ relativamente estável, com pequena tendência de queda. Os dois tipos de minério de talco do Grupo Itaiacoca (talco-xisto em zonas de cisalhamento e talco maciço fino), ocupam regiões similares no campo destas variações isotópicas. Os carbonatos relacionados a processos superficiais (calcita, aragonita) mostram uma tendência contrastante com a da talcificação, com marcante diminuição de $\delta \mathrm{C}$, enquanto que $\delta O$ permanece numa faixa de valores similar ao dos metadolomitos originais. Cabe notar que uma amostra de calcita de talco xisto apresenta valores isotópicos similares aos dos carbonatos supergênicos, com de $\delta \mathrm{O}$ similar ao do metadolomito original, mas com $\delta \mathrm{C}$ fortemente negativo; esta amostra foi mantida com a notação de calcita em talco xisto, para não mascarar a sobreposição de eventos de recristalização que caracterizam as rochas carbonáticas submetidas a diversos ciclos de metamorfismo, hidrotermalismo e, finalmente, intemperismo.

Pares coexistentes de dolomita e calcita mostram dois tipos de tendência (Figura 31). Nos metadololomitos sujeitos apenas ao metamorfismo regional e aos processos superimpostos de talcificação, a dolomita apresenta razões isotópicas maiores que a calcita tanto em carbono como em oxigênio, sugerindo equilíbrio isotópico. A mesma 
situação se repete nos pares calcita-dolomita de brechas e de metadolomito talcificado, com dolomita sempre com razões mais elevadas que calcita, entretanto com intervalos variáveis em cada caso. Nos metadolomitos afetados por metamorfismo de contato tanto na auréola do Cmplexo Granítico Cunhaporanga como na proximidade dos diques de diabásio, os pares calcita-dolomita estão em desequilíbrio isotópico, pelo menos em termos de $\delta^{13} \mathrm{C}$, onde os valores em calcita são superiores aos em dolomita.

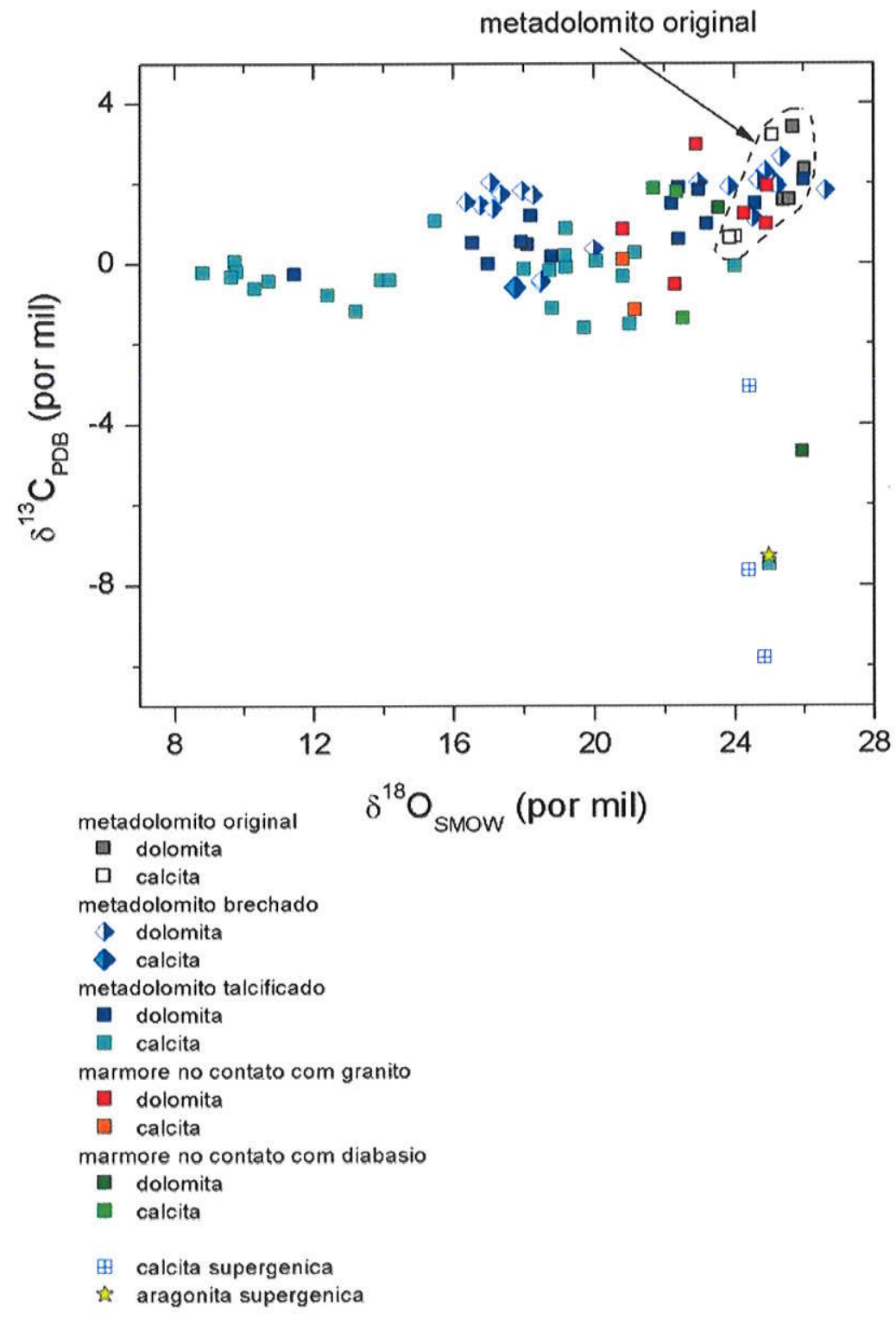

Figura 30. Razões de isótopos estáveis de carbono e oxigênio de carbonatos do Grupo Itaiacoca. 

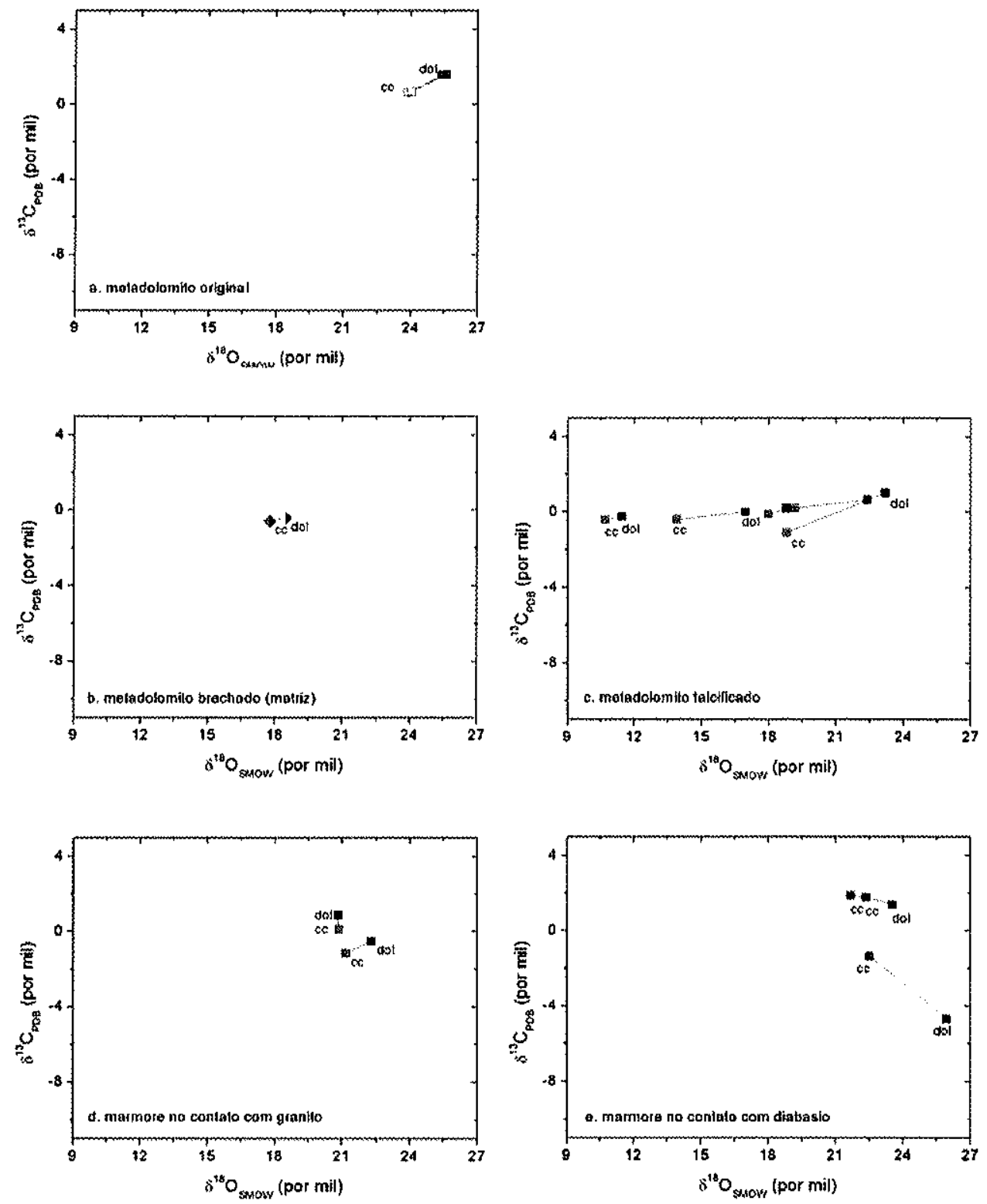

Figura 31. Razões isotópicas de carbono e oxigênio de pares coexistentes de dolomita e calcita.

As brechas tectônicas são compostas por clastos e matriz essencialmente dolomíticos, sendo que os clastos têm a mesma isotópica do metadolomito original e a matriz apresenta desvio para valores de $\delta^{18} \mathrm{O}$ inferiores, da ordem de 16 a $18 \%$, mas sem alterar os valores de $\delta^{13} \mathrm{C}$ (Figura 32). 


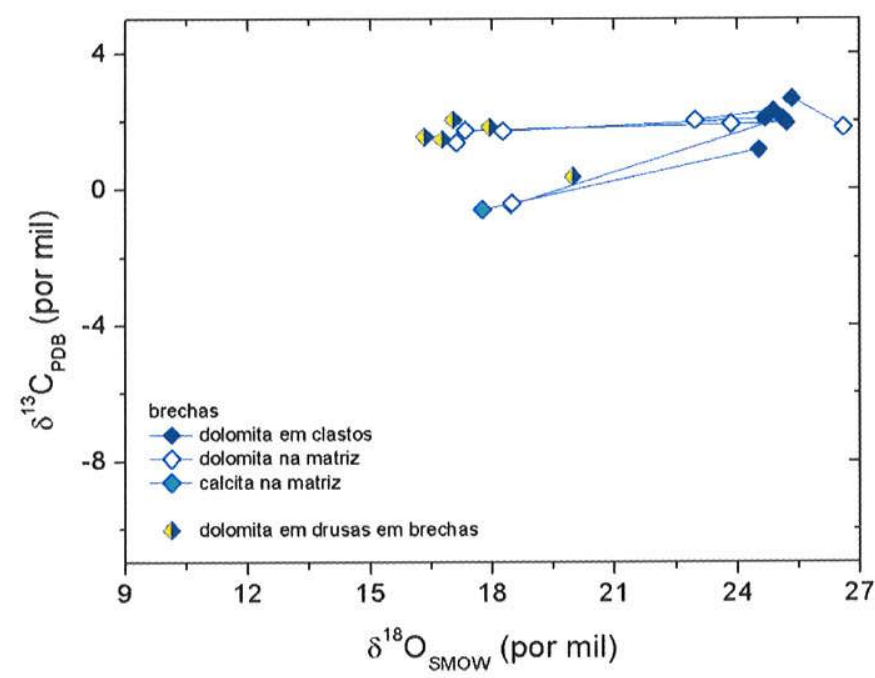

Figura 32. Razões isotópicas de carbono e oxigênio de pares clasto-matriz em metadolomito brechado.

No intuito de testar o equilíbrio isotópico entre os pares coexistentes dolomitacalcita, foi aplicado o fator de fracionamento de Sheppard e Schwarz (1970). A figura 33 apresenta o fracionamento isotópico em termos de $\ln 1000 \alpha^{13} \mathrm{C}_{(\text {dol-cc) }}$ versus $\ln 1000 \alpha^{18} \mathrm{O}_{(\text {dol-cc) }}$, que equivalem às diferenças $\left(\delta^{13} \mathrm{C}_{\text {dolomita }}-\delta^{13} \mathrm{C}_{\text {calcita }}\right)$ e $\left(\delta^{18} \mathrm{O}_{\text {dolomita }}{ }^{-}\right.$ $\delta^{18} \mathrm{O}_{\text {calcita }}$ ), respectivamente. A figura apresenta também a linha de equilíbrio isotópico determinada para pares dolomita-calcita através das respectivas equações de fracionamento isotópico em função da temperatura. Três pares se situam sobre a linha de equilíbrio isotópico, um em metadolomito original e dois em mármore no contato com granito. As temperaturas calculadas pelo fracionamento de $\delta \mathrm{C}$ e de $\delta \mathrm{O}$ destas três amostras são coerentes: metadolomito original, amostra PTI06AB $\delta^{18} \mathrm{O} 306^{\circ} \mathrm{C}, \delta^{13} \mathrm{C}$ $305^{\circ} \mathrm{C}$; mármores amostra PTI22CB $\delta^{18} \mathrm{O} 461^{\circ} \mathrm{C}, \delta^{13} \mathrm{C} 477^{\circ} \mathrm{C}$; e amostra PTI22CA $\delta^{18} \mathrm{O}$ $504^{\circ} \mathrm{C}, \delta^{13} \mathrm{C} 490^{\circ} \mathrm{C}$. Os demais pares plotados no gráfico, mesmo aqueles próximos à linha de equilíbrio isotópico apresentam temperaturas discrepantes para os dois sistemas isotópicos em consequência de desequilíbrio. 


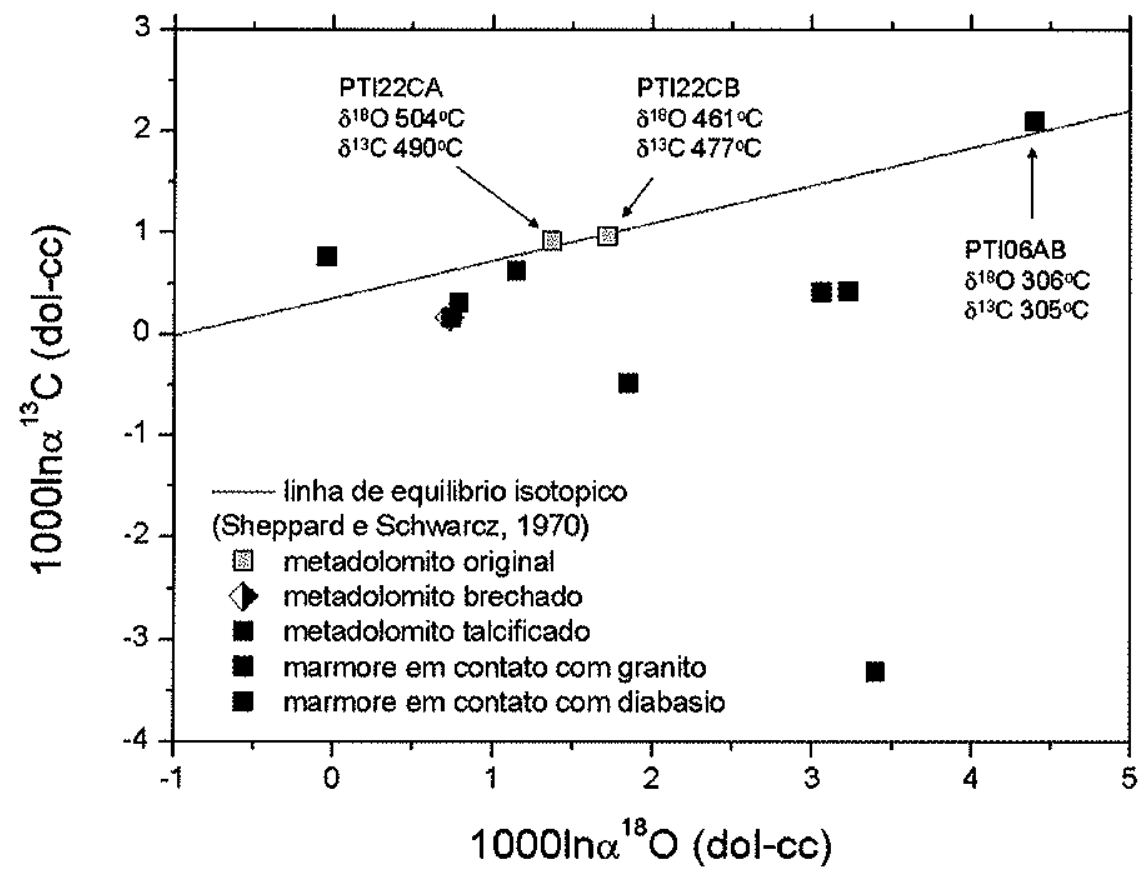

Figura 33. Fracionamento isotópico de carbono $\left(1000 \ln \alpha^{13} \mathrm{C}_{(\text {dôl-cc) }}\right)$ e de oxigênio $\left(1000 \ln \alpha^{18} \mathrm{O}_{(\text {dol-cc) }}\right)$ em pares coexistentes de dolomita e calcita. A reta $\mathbf{A}$ representa a linha de equilíbrio isotópico entre dolomita e calcita (Sheppard e Schwarcz, 1970). 
Tabela 7. Dados de isótopos estáveis de carbono e oxigênio, de variedades litológicos do Grupo Itaiacoca $(\mathrm{cc}=$ calcita; dol=dolomita; ar = aragonita $)$.

\begin{tabular}{|c|c|c|c|c|}
\hline Amostra & $\delta^{18} \mathrm{O}_{S M O W \% o}$ & $\delta^{13} \mathrm{C}_{\mathrm{PDB}} \%$ & $\min$. & comentários \\
\hline \multicolumn{5}{|l|}{$\begin{array}{l}\text { metadolomito } \\
\text { original }\end{array}$} \\
\hline PTI 01 AA & 26,02 & 2,35 & dol & metadolomito original rocha total \\
\hline PTI 22 CA & 24,04 & 0,67 & $c c$ & $\begin{array}{l}\text { metadolomito cinza claro estratificado (fração } \\
\text { calcita) }\end{array}$ \\
\hline PTI $22 \mathrm{CB}$ & 23,87 & 0,64 & $\mathrm{cc}$ & $\begin{array}{l}\text { metadolomito cinza claro estratificado com } \\
\text { estromatólitos (fração calcita) }\end{array}$ \\
\hline PTI $22 \mathrm{CA}$ & 25,41 & 1,59 & dol & $\begin{array}{l}\text { metadolomito cinza claro estratificado (fração } \\
\text { dolomita) }\end{array}$ \\
\hline PTI $22 \mathrm{CB}$ & 25,59 & 1,60 & dol & $\begin{array}{l}\text { metadolomito cinza claro estratificado com } \\
\text { estromatólitos (fração dolomita) }\end{array}$ \\
\hline PII $01 \mathrm{CA} 1$ & 25,72 & 3,41 & dol & metadolomito original \\
\hline $\begin{array}{l}\text { PTI } 01 \text { CA2 } \\
\text { metadolomito } \\
\text { talcificado }\end{array}$ & 25,12 & 3,19 & $\mathrm{cc}$ & metadolomito cinza estratificado (So) com vênulas \\
\hline PTr $01 \mathrm{AB} 1$ & 25,12 & 2,08 & dol & brecha clasto \\
\hline PTI 01 AB 2 & 18,47 & $-0,46$ & dol & brecha matriz \\
\hline PTI OI AE & 16,53 & 0,53 & dol & veio de dolomita branca com talco na borda \\
\hline PTI 01 AI & 19,98 & 0,38 & dol & dolomita em drusas ocupando cavidades em veios \\
\hline PTI OI AK & 17,94 & 1,84 & dol & veio de dolomita com cavidades \\
\hline PTI $01 \mathrm{BD}$ & 17,04 & 2,05 & dol & dolomita em drusas ocupando cavidades em veios \\
\hline PTI 01 BE & 16,76 & 1,48 & dol & veio de dolomita com cavidades \\
\hline PTI $01 \mathrm{CC} 1$ & 24,88 & 2,31 & dol & brecha angulosa maciça (clastos) \\
\hline PTI 01 CC2 & 22,97 & 2,04 & dol & brecha angulosa maciça (matriz) \\
\hline PTI 01 CDI & 25,22 & 1,95 & dol & $\begin{array}{l}\text { brecha angulosa maciça (clastos) com mais matriz } \\
\text { que PTI } 01 \mathrm{CC}\end{array}$ \\
\hline PTI 01 CD2 & 17,35 & 1,75 & dol & $\begin{array}{l}\text { brecha angulosa maciça (matriz) com mais matriz } \\
\text { que PTI } 01 \mathrm{CC}\end{array}$ \\
\hline PTI 01 CE1 & 24,68 & 2,09 & dol & brecha com cavidades (clastos) \\
\hline PTI 01 CE2 & 18,26 & 1,72 & dol & brecha com cavidades (matriz) \\
\hline PTI $01 \mathrm{CG}$ & 16,34 & 1,55 & dol & cristais de dolomita em cavidade de brecha \\
\hline PTI 01 CH1 & 17,12 & 1,39 & dol & dolomita, cristal grande branco \\
\hline PTI $01 \mathrm{CH}_{2}$ & 23,85 & 1,93 & dol & dolomita, matriz cinza fina \\
\hline PTI $01 \mathrm{CI}$ & 24,53 & 1,16 & dol & brecha (fragmento escuro) \\
\hline PTI $01 \mathrm{CI} 2$ & 17,75 & $-0,58$ & $\mathrm{cc}$ & brecha matriz, fração calcita \\
\hline PTI $01 \mathrm{CI} 2$ & 18,48 & $-0,41$ & dol & brecha matriz, fração dolomita \\
\hline PTI $01 \mathrm{CJ} 1$ & 25,34 & 2,66 & dol & brecha (fragmento escuro) \\
\hline PTI $01 \mathrm{CJ} 2$ & 26,61 & 1,83 & dol & brecha (matriz branca) \\
\hline PTI 02 AG 1 & 18,10 & 0,49 & dol & dolomita porfiroblástica poiquilítica \\
\hline PTI 02 AG 2 & 17,92 & 0,56 & dol & $\begin{array}{l}\text { dolomita intercrescida na dol porfiroblástica } \\
\text { poiquilítica }\end{array}$ \\
\hline PTI 02 CA & 8,80 & $-0,20$ & $\mathrm{cc}$ & calcita em talco xisto \\
\hline PTI $02 \mathrm{CB}$ & 22,98 & 1,84 & dol & metadolomito sacaróide (rocha total) \\
\hline PTI $02 \mathrm{CC}$ & 10,70 & $-0,41$ & $\mathrm{cc}$ & metadolomito com talco e calcita \\
\hline PTI $02 \mathrm{CC}$ & 11,44 & $-0,25$ & dol & metadolomito com talco e calcita \\
\hline PTI 02 CI & 24,00 & $-0,05$ & $\mathrm{cc}$ & calcita em talco xisto \\
\hline PTI 02 D2 & 10,29 & $-0,61$ & $c c$ & calcita em talco xisto \\
\hline PTI $02 \mathrm{DA}$ & 18,23 & 1,20 & dol & metadolomito cinza claro prox. faixa com talco \\
\hline
\end{tabular}


Tabela 7. (continuação).

\begin{tabular}{|c|c|c|c|c|}
\hline Amostra & $\delta^{18} \mathrm{O}_{\mathrm{SMON}} \%_{0}$ & $\delta^{13} \mathrm{C}_{\mathrm{PDPB}} \%$ & $\min$. & comentários \\
\hline \multirow{2}{*}{\multicolumn{5}{|c|}{$\begin{array}{l}\text { metadolomito } \\
\text { talcificado }\end{array}$}} \\
\hline & & & & \\
\hline PTI 02 DF & 9,72 & 0,08 & $\mathrm{cc}$ & $\begin{array}{l}\text { metadolomito brechado com talco e grandes cristais } \\
\text { de calcita }\end{array}$ \\
\hline PTI 02 DK & 9,76 & $-0,19$ & $\mathfrak{c c}$ & calcita geminada com feições concêntricas ao redor \\
\hline PTI 02 DI & 10,29 & $-0,61$ & $\mathrm{cc}$ & talco rosado com carbonatos \\
\hline PTI $02 \mathrm{DO}$ & 13,91 & $-0,40$ & $\mathrm{cc}$ & metadolomito com qz isolado (fraçāo calcita) \\
\hline PTI 02 DO & 16,97 & 0,01 & dol & metadolomito com qz isolado (fração dolomita) \\
\hline PTI 02 DP & 18,00 & $-0,11$ & $\mathrm{cc}$ & $\begin{array}{l}\text { metadolomito com tc, cc, qz, e feições concêntricas } \\
\text { (fração calcita) }\end{array}$ \\
\hline PTI 02 DP & 18,79 & 0,20 & dol & $\begin{array}{l}\text { metadolomito com tc, } c c, q z \text {, e feições concêntricas } \\
\text { (fração dolomita) }\end{array}$ \\
\hline PTI 02 DS & 9,62 & $-0,30$ & $\mathrm{cc}$ & veios de $\mathrm{qz} \operatorname{com} \mathrm{cc}+/-\mathrm{tc}$ \\
\hline PTI $02 \mathrm{G}$ & 12,39 & $-0,76$ & $\mathrm{cc}$ & calcita em talco xisto \\
\hline \multirow[b]{2}{*}{ PTI 06 BA } & 18,84 & $-1,09$ & $\mathrm{cc}$ & $\begin{array}{l}\text { dol }+t c+q z \text { (talco maciço, talcificação incipiente } \\
\text { em fraturas) }\end{array}$ \\
\hline & 23,16 & 0,98 & dol & $\begin{array}{l}\text { dol }+ \text { tc }+ \text { qz (talco maciço, talcificação incipiente } \\
\text { em fraturas) }\end{array}$ \\
\hline PTI $22 \mathrm{BG}$ & 21,15 & 0,29 & $\mathrm{cc}$ & veio de $q z$ leitoso com calcita \\
\hline PTI $22 \mathrm{CE}$ & 19,20 & $-0,07$ & cc & calcita do plano de cisalhamento \\
\hline PTI $22 \mathrm{CJ}$ & 20,76 & $-0,30$ & $\mathrm{cc}$ & veio que qz com tremolita (?) dobrado \\
\hline PTI 22CD & 20,05 & 0,07 & $\mathrm{cc}$ & carbonatos em talco xisto (fração calcita) \\
\hline PTI $38 \mathrm{C}$ & 18,74 & $-0,16$ & $\mathfrak{c c}$ & calcita em talco xisto \\
\hline PTI 42 AA & 24,63 & 1,50 & dol & metadolomito cinza com raras fraturas (sem talco) \\
\hline PTI $42 \mathrm{AC} 1$ & 19,17 & 0,21 & $\mathrm{cc}$ & metadolomito cinza (fração calcita) \\
\hline PTI $42 \mathrm{AC}]$ & 22,40 & 0,63 & dol & metadolomito cinza (fração dolomita) \\
\hline PTI 42 AC2 & 13,19 & $-1,16$ & $\mathrm{cc}$ & borda microcristalina de veio (fração calcita) \\
\hline PTl $42 \mathrm{AC} 3$ & 14,16 & $-0,39$ & $\mathfrak{c c}$ & $\begin{array}{l}\text { metadolomito com planos de tc }+ \text { cc (tipo talco } \\
\text { maciço) }\end{array}$ \\
\hline PTI 42 AE 1 & 19,66 & $-1,64$ & $\mathrm{cc}$ & brecha, fragmento de dolomito branco \\
\hline PTI 42 AE 2 & 21,04 & $-1,49$ & $\mathrm{cc}$ & $\begin{array}{l}\text { brecha, porção verde clara, esbraquiçada com } \\
\text { serpentina }\end{array}$ \\
\hline PTI 42 AJ & 24,99 & $-7,49$ & $c c$ & $\begin{array}{l}\text { metadolomito silicificado } \mathrm{com} \text { tc }+\mathrm{cc} \text { (tipo talco } \\
\text { maciço) }\end{array}$ \\
\hline PTI 45 B I & 15,47 & 1,08 & $\mathrm{cc}$ & metadolomito com talco e calcita (fração calcita) \\
\hline PTI 45 B 2 & 19,20 & 0,90 & $\mathrm{cc}$ & metadolomito com talco e calcita (fraçāo calcita) \\
\hline PTI $65 \mathrm{~A}$ & 26,04 & 2,14 & dol & $\begin{array}{l}\text { metadolomito cinza médio com talco em sutis } \\
\text { planos de fratura }\end{array}$ \\
\hline PTI $65 \mathrm{~B}$ & 22,41 & 1,87 & dol & $\begin{array}{l}\text { metadolomito cinza médio com talco em sutis } \\
\text { planos de fratura }\end{array}$ \\
\hline PT1 $65 \mathrm{C}$ & 22,20 & 1,45 & dol & metadolomito com lente de talco \\
\hline
\end{tabular}


Tabela 7. (continuação).

\begin{tabular}{|c|c|c|c|c|}
\hline Amostra & $\begin{array}{c}\delta^{18} \mathrm{O}_{\text {SMOW }} \\
\% \% \\
\end{array}$ & $\delta^{13} \mathrm{C}_{\mathrm{PDBB}} \%$ & $\min$. & comentários \\
\hline \multicolumn{5}{|l|}{$\begin{array}{l}\text { metadolomito no } \\
\text { contato granito }\end{array}$} \\
\hline PTI 05 a AG & 24,94 & 1,95 & dol & tremolita mármore prox contato com granito \\
\hline PTI 43 AA & 20,82 & 0,12 & $\mathrm{cc}$ & tremolita mármore prox contato com granito \\
\hline PTI 43 AA & 20,82 & 0,88 & dol & tremolita mármore prox contato com granito \\
\hline PTI $43 \mathrm{AB}$ & 21,16 & $-1,14$ & $c c$ & tremolita mármore sacaróide com calcita \\
\hline PTI $43 \mathrm{AB}$ & 22,31 & $-0,51$ & dol & tremolita mármore sacaróide com calcita \\
\hline PTI 47 AA & 24,29 & 1,25 & dol & tremolita mármore sacaróide \\
\hline PTI $47 \mathrm{AC}$ & 24,91 & 1,00 & dol & tremolita mármore sacaróide com calcita \\
\hline PTI 48 & 22,90 & 2,98 & dol & mármore dolomítico com talco (retrometamórfico) \\
\hline \multicolumn{5}{|l|}{$\begin{array}{l}\text { metadolomito no } \\
\text { contato diabásio }\end{array}$} \\
\hline PTI $02 \times \mathrm{cc}$ & 22,53 & $-1,36$ & $\mathrm{cc}$ & zona de contato com dique de diabásio \\
\hline PTI $02 \mathrm{X}$ dol & 25,93 & $-4,68$ & dol & zona de contato com dique de diabásio \\
\hline PTI 37 AA cc 1 & 21,69 & 1,89 & $\mathrm{cc}$ & minério S. Judas (fração calcita) próx. đique diabásio \\
\hline PTI 37 AA cc 2 & 22,33 & 1,79 & $\mathrm{cc}$ & minério S. Judas (fração calcita) próx. dique diabásio \\
\hline PTI 37 AA dol & 23,54 & 1,40 & dol & $\begin{array}{l}\text { minério S. Judas (fração dolomita) próx. dique } \\
\text { diabásio }\end{array}$ \\
\hline \multicolumn{5}{|l|}{$\begin{array}{l}\text { carbonatos } \\
\text { supergênicos }\end{array}$} \\
\hline PTI $02 \mathrm{X}$ ar & 24,97 & $-7,29$ & ar & zona de contato com dique de diabásio \\
\hline PTI $22 \mathrm{BH}$ & 24,41 & $-7,63$ & $\mathrm{cc}$ & calcita que reveste fraturas superficiais \\
\hline PTI $22 \mathrm{CM}$ & 24,43 & $-3,07$ & $\mathrm{cc}$ & calcita supergênica \\
\hline PTI $22 \mathrm{CN}$ & 24,85 & $-9,79$ & $\mathfrak{c c}$ & calcita supergênica \\
\hline
\end{tabular}

Tabela 8. Intervalos de valores de isótopos estáveis de carbono e oxigênio de acordo com o tipo litológico.

\begin{tabular}{|c|c|c|c|c|c|c|}
\hline \multirow[b]{2}{*}{ metadolomito } & \multicolumn{2}{|c|}{ dolomita } & \multicolumn{2}{|c|}{ calcita } & \multicolumn{2}{|c|}{ aragonita } \\
\hline & $\begin{array}{l}\delta^{18} \mathrm{O} \% \circ \\
\text { SMOW }\end{array}$ & $\begin{array}{c}\delta^{13} \mathrm{C} \% \\
\mathrm{PDB}\end{array}$ & $\begin{array}{l}\delta^{18} \mathrm{O} \% 0 \\
\text { SMOW }\end{array}$ & $\begin{array}{c}\delta^{13} \mathrm{CDB} \% \\
\end{array}$ & $\begin{array}{c}\delta^{18} \mathrm{O} \% \\
\text { SMOW }\end{array}$ & $\begin{array}{c}\delta^{13} \mathrm{C} \% \circ \\
\mathrm{PDB}\end{array}$ \\
\hline original & 25,6 a 26,0 & 1,6 a 3,4 & 23,9 a 25,1 & 0,6 a 3,2 & -- & $\cdots$ \\
\hline brechado & 16,3 a 26,6 & $-0,5$ a 2,7 & 17,8 & $-0,6$ & -- & -- \\
\hline talcificado & 11,4 a 26,6 & $-0,3$ a 2,1 & 8,8 a 25,0 & $-1,6$ a 1,1 & -- & $\ldots$ \\
\hline em contato com granito & 20,8 a 24,9 & $-0,5$ a 3,0 & 20,8 a 21,2 & $-1,1$ a 0,1 & -- & 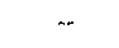 \\
\hline em contato com diabásio & 23,5 a 25,9 & $-4,7$ a 1,4 & 21,7 a 22,5 & $-1,4$ a 1,9 & -- & -- \\
\hline carbonatos supergênicos & $\ldots$ & -- & 24,4 a 24,8 & $-3,1$ a $-9,8$ & 25,0 & $-7,3$ \\
\hline
\end{tabular}




\subsection{Inclusões fluidas}

Este item apresenta os primeiros resultados da análise microtermométrica de inclusões fluidas no Grupo Itaiacoca. Foram inicialmente selecionadas três amostras para o estudo petrográfico de inclusões fluidas, sendo uma amostra (PT102AI) com calcita e quartzo de talco xisto da zona principal da talcificação, diretamente associada às zonas de cisalhamento transcorrente, e duas amostras (PTI05bac, PTI43AC) da auréola de metamorfismo de contato com o Complexo Granítico Cunhaporanga.

O estudo das inclusões fluidas em metadolomitos e jazidas de talco do Grupo Itaiacoca se encontra em andamento. As amostras das zonas de cisalhamento ainda não estão completamente analisadas e discutidas, assim como de outros contextos geológicos que ainda serão estudados.

A petrografia das inclusões fluidas em cristais de quartzo e carbonato considerou os seguintes critérios petrográficos: (a) inclusões primárias encontram-se distribuídas aleatoriamente em certas regiões dos cristais; (b) inclusões pseudo-secundárias encontram-se dispostas ao longo de planos de fraturas cicatrizadas internas aos grãos; (c) inclusões secundárias estão situadas em planos e trilhas transgranulares.

Os dados microtermométricos referem-se às temperaturas eutética ( $\mathrm{Te}$, primeiro sinal de fusão no aquecimento da inclusão totalmente congelada), de fusão do $\mathrm{CO}_{2}$ $\left(\mathrm{TfCO}_{2}\right)$, de fusão do gelo (Tfg), de fusão de clatratos (Tclat), de homogeneização do $\mathrm{CO}_{2}\left(\mathrm{ThCO}_{2}\right)$ e de homogeneização total (Thtot).

\subsubsection{Inclusões fluidas em zonas de cisalhamento}

As inclusões primárias dos cristais de quartzo possuem, geralmente, dimensões muito reduzidas. Além disso, esses cristais normalmente apresentam uma profusão de trilhas de inclusões entrecruzadas, dificultando o estabelecimento da cronologia relativa. Por esse motivo, foram inicialmente selecionadas inclusões primárias e secundárias presentes nos cristais de carbonato, em função de suas maiores dimensões e da maior facilidade na determinação das diferentes etapas de aprisionamento. Em zonas de 
cisalhamento sujeitas a reativações são comuns fenômenos de recristalização, tanto em carbonatos como em quartzo.

As inclusões fluidas analisadas possuem morfologias desde irregulares até constituindo cristais negativos, sendo estas últimas bastante comuns. As dimensões normalmente variam de $<4 \mu \mathrm{m}$ a $>80 \mu \mathrm{m}$, tendo sido estudadas aquelas situadas entre $4 \mathrm{e}$ $48 \mu \mathrm{m}$. As inclusões estudadas são essencialmente aquosas bifásicas, não tendo sido observadas mudanças de fase indicativas de outro componente volátil associado. Os dados microtermométricos completos e os respectivos parâmetros calculados das inclusões individuais da amostra PTI02AI estão apresentados na Anexo Tabela 8.

Nesta primeira etapa foram analisadas inclusões de quatro regiões em uma mesma amostra, sendo três delas consideradas primárias (fragmentos $4 \mathrm{~b}, 7 \mathrm{a}, 12$ ) e uma tendo sido possivelmente afetada por fluido tardios (fragmento $3 \mathrm{c}$ ).

O ponto eutético (Te) indica a composição das soluções aquosas e é semelhante nas inclusões fluidas primárias (Fragmentos 7a, 12, 4B) e secundárias (Fragmento $3 \mathrm{C}$ ), como apresentado na figura 34 , situando-se num intervalo de -50 a $-39^{\circ} \mathrm{C}$. Foram observados indícios de fusão inicial (Te) desde valores ao redor de $-50^{\circ} \mathrm{C}$, tendo sido, no entanto, registradas apenas as temperaturas onde esse fenômeno ocorre de maneira bem nítida. Portanto, as Te reais situam-se em valores algo inferiores aos representados na figura 34. Essas temperaturas são indicativas de sistemas compostos por $\mathrm{H}_{2} \mathrm{O}-\mathrm{NaCl}$ ( $\mathrm{Te}$ $=-21,2^{\circ} \mathrm{C}$, segundo Davis et al., 1990) com a presença de íons $\mathrm{Ca}^{2+} \mathrm{e}^{2+}$, responsáveis pelas reduções de Te. Nos sistemas $\mathrm{H}_{2} \mathrm{O}+\mathrm{NaCl}+\mathrm{CaCl}_{2}$ e $\mathrm{H}_{2} \mathrm{O}+\mathrm{NaCl}+\mathrm{MgCl}_{2}$, as temperaturas eutéticas estáveis situam-se em $-52^{\circ} \mathrm{C}$ e $-35^{\circ} \mathrm{C}$, respectivamente (Davis et al., 1990). No entanto, os autores obtiveram temperaturas variando de $-47^{\circ} \mathrm{C}$ a $-53^{\circ} \mathrm{C}$, no primeiro caso, e intervalos de variação de $-40^{\circ} \mathrm{C}$ a $-33^{\circ} \mathrm{C}$ e de $-50^{\circ} \mathrm{C}$ a $-45^{\circ} \mathrm{C}$, no segundo, ou valores ainda mais baixos indicativos de metaestabilidade. Como enfatizam Roedder (1984) e Goldstein \& Reynolds (1994), a fusão inicial bem definida abaixo de $-40^{\circ} \mathrm{C}$ é indicativa da presença de um íon divalente $\left(\mathrm{Ca}^{2+} \mathrm{e} / \mathrm{ou} \mathrm{Mg}^{2+}\right)$ na solução.

A temperatura de fusão do gelo (Tfg), que reflete a salinidade dos fluidos presentes nas inclusões, apresenta pequena variação nas inclusões primárias dos cristais estudados (figura 35). Os valores de $\mathrm{Tfg}$ variam principalmente de $-2 \mathrm{a}-1^{\circ} \mathrm{C}$, com maior quantidade de medidas ao redor de $-2,5^{\circ} \mathrm{C}$, no fragmento $4 \mathrm{~B}$. Nos fragmentos $7 \mathrm{~A}$ e 12 , Tfg varia de -3 a $0^{\circ} \mathrm{C}$, com maior quantidade de medidas entre -3 e $-1^{\circ} \mathrm{C}$. Nas inclusões 
secundárias (frag $3 \mathrm{C}$ ), as $\mathrm{Tfg}$ situaram-se principalmente entre -3 e $0^{\circ} \mathrm{C}$, com maior quantidade de medidas ao redor de $-1,5^{\circ} \mathrm{C}$, embora tenha sido obtida uma quantidade expressiva de valores próximos ou maiores que $0^{\circ} \mathrm{C}$, sendo os últimos indicativos de metaestabilidade.
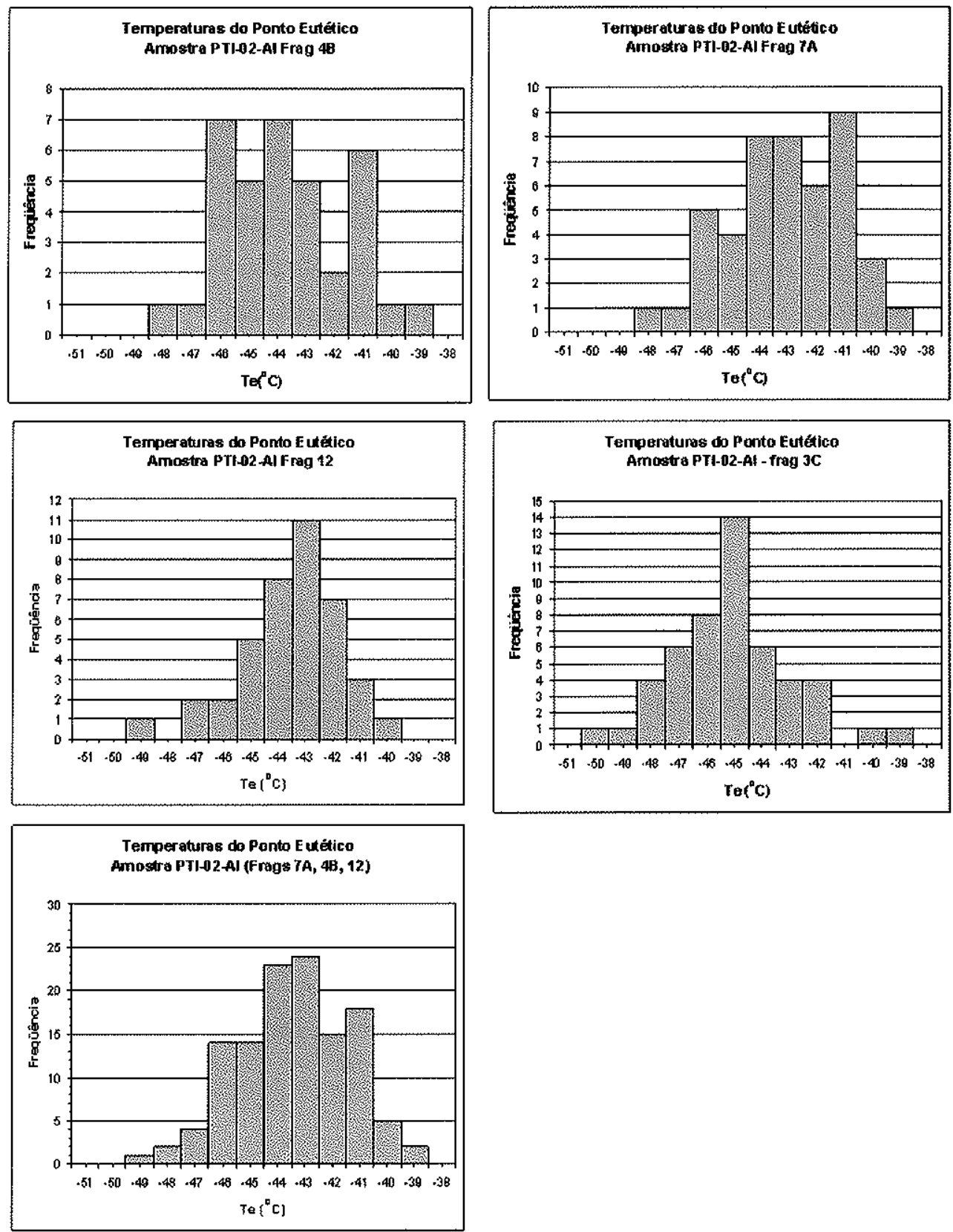

Figura 34. Histogramas de temperatura eutética $\left(\mathrm{Te}{ }^{\circ} \mathrm{C}\right.$ ), amostra PTI 02 AI (calcita). 

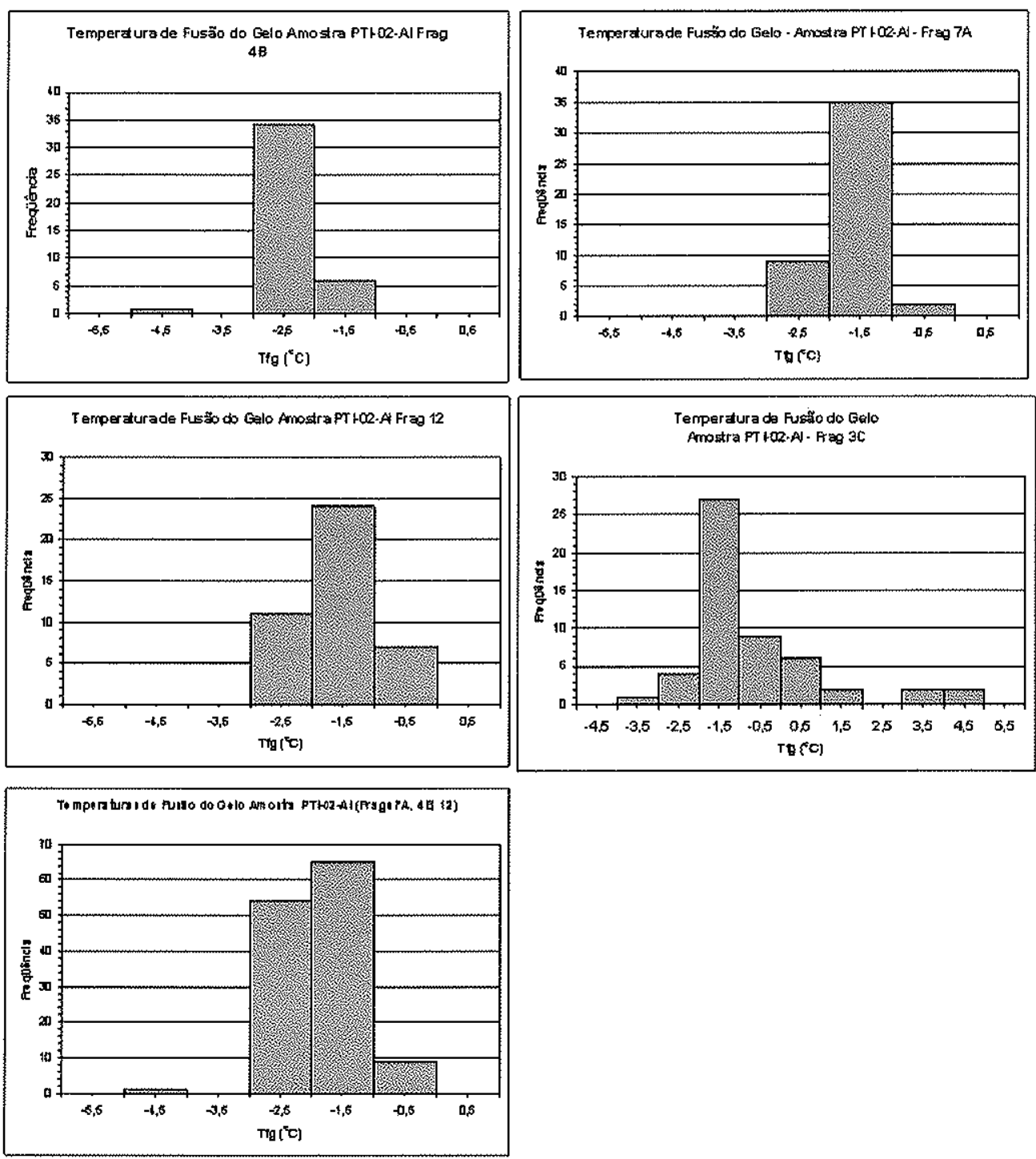

Figura 35. Histogramas de temperatura de fusão do gelo (Tfg ${ }^{\circ} \mathrm{C}$ ), amostra PTI 02 AI (calcita).

A salinidade determinada a partir das $\mathrm{Tfg}$ do fragmento $4 \mathrm{~B}$ situa-se principalmente entre 3 e $4 \%$ em peso do $\mathrm{NaCl}$ equivalente, havendo maior concentração de valores ao redor de $3,5 \%$ em peso do $\mathrm{NaCl}$ equivalente (Figura 36). Nos fragmentos 7A e 12 a salinidade varia entre 2 e $4 \%$ em peso do $\mathrm{NaCl}$ equivalente, embora o segundo apresente quantidade significativa de valores em torno de $0,5 \% \mathrm{em}$ peso do $\mathrm{NaCl}$ equivalente. $\mathrm{O}$ dados também mostram que a salinidade das inclusões 
secundárias (frag $3 \mathrm{C}$ ) tende a ser inferior, variando principalmente de 0 a $3 \%$ em peso do $\mathrm{NaCl}$ equivalente, com predominância dos valores situados ao redor de $2,5 \% \mathrm{em}$ peso do $\mathrm{NaCl}$ equivalente. Considerando-se o total de inclusões primárias, observa-se uma quantidade expressiva de medidas de Tfg entre $-2,5$ e $-1,5^{\circ} \mathrm{C}$, indicando uma faixa de salinidade variando de 2,5 a $3,5 \%$ em peso do $\mathrm{NaCl}$ equivalente.
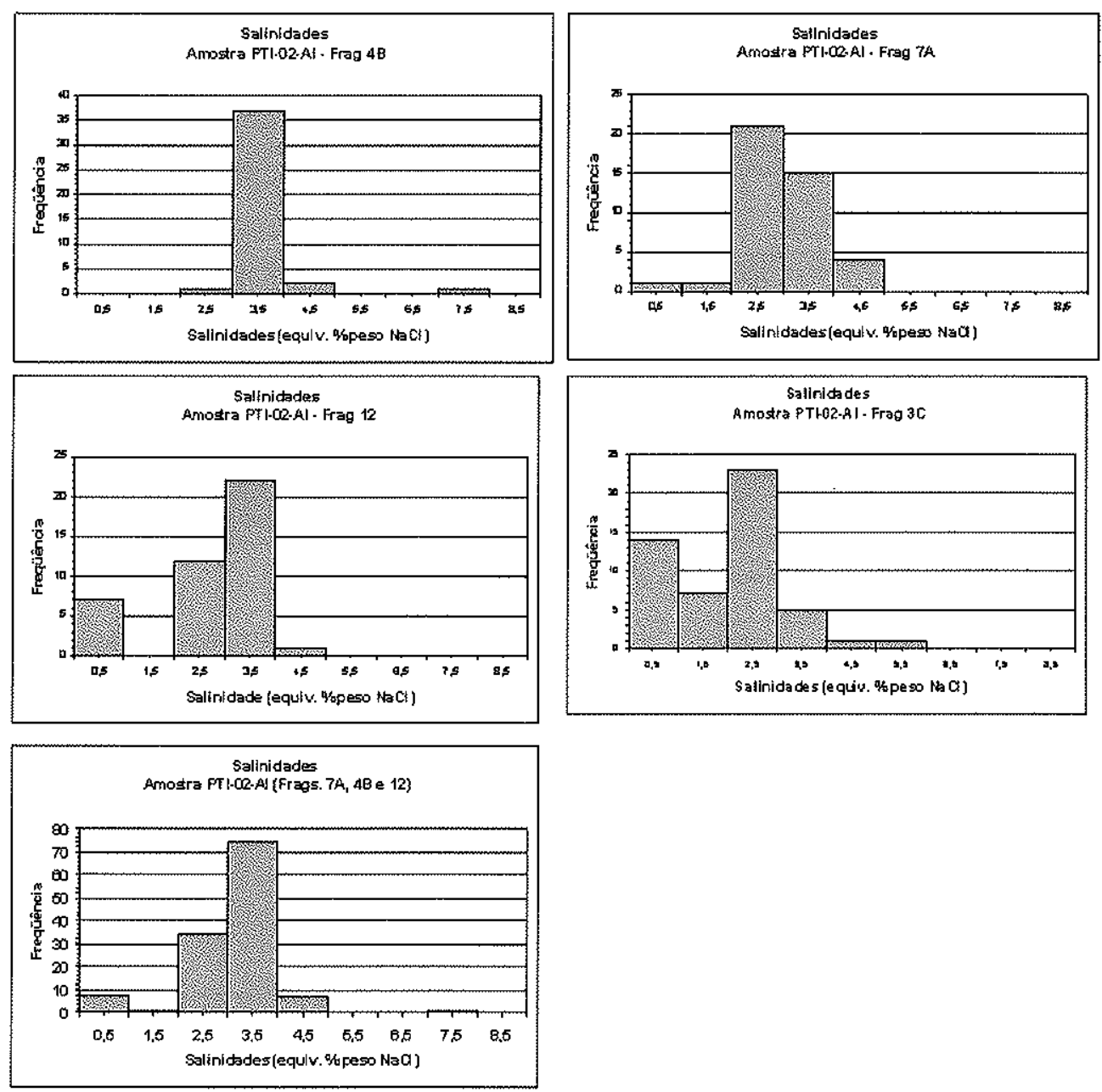

Figura 36. Histogramas de salinidade, amostra PTI 02 AI (calcita).

A temperatura de homogeneização total das inclusões primárias (Thtot) situa-se principalmente entre 170 e $210^{\circ} \mathrm{C}$ no Frag $4 \mathrm{~B}$, entre 200 e $230^{\circ} \mathrm{C}$, no fragmento $7 \mathrm{~A}$, e entre 210 e $220^{\circ} \mathrm{C}$, no fragmento 12 , embora existam valores inferiores, principalmente 
neste último fragmento. Nas inclusões secundárias do fragmento $3 \mathrm{C}$, as Thtot apresentaram um pico bem definido em $130^{\circ} \mathrm{C}$, indicando menor temperatura mínima de aprisionamento (Figura 37). Alguns valores superiores à faixa de maior freqüência representam, em muitos casos, modificações por escape de fluidos, cujas feições foram ocasionalmente observadas. O diagrama representativo do histograma de freqüência das temperaturas de homogeneização dos três fragmentos com inclusões primárias, mostra um intervalo de maior quantidade de valores entre 210 e $220^{\circ} \mathrm{C}$, com algumas concentrações de medidas ao redor de $130^{\circ} \mathrm{C}$ que corresponde ao pico de Thtot das inclusões secundárias. 

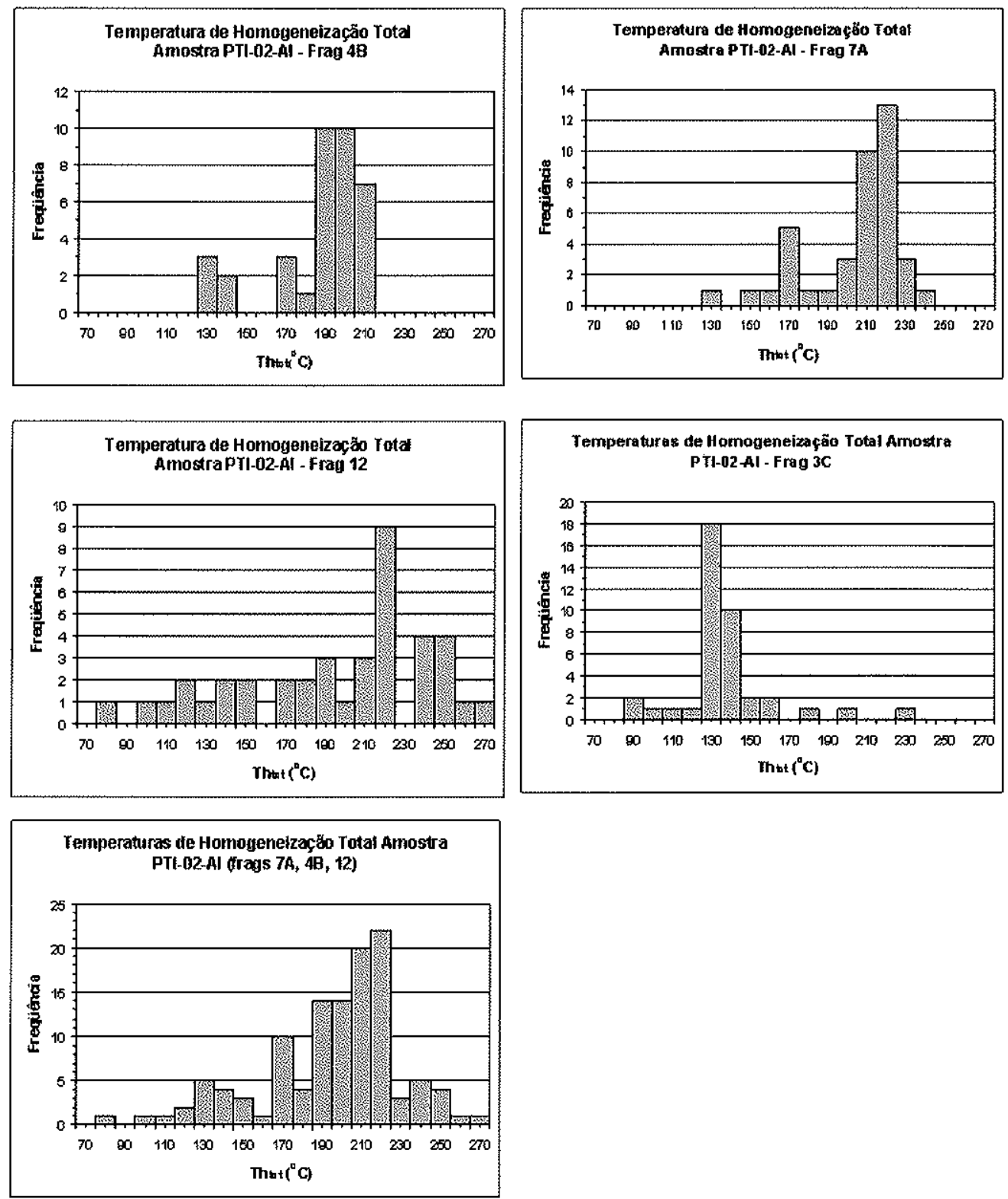

Figura 37. Histogramas de temperatura de homogeneização total, amostra PTI 02 AI (calcita).

Os diagramas Thtot $\mathrm{x}$ Tfg e Thtot $\mathrm{x}$ Salinidade (Figura 38) mostram que o fluido presente nas inclusões secundárias do fragmento $3 \mathrm{C}$, de menor salinidade, pode ter modificado aquelas aprisionadas anteriormente, principalmente no caso do fragmento 12, cujo histograma de frequiência das temperaturas de homogeneização total também apresenta a maior assimetria em direção aos valores mais baixos. A tendência em 
direção às menores temperaturas de homogeneização, observada nos histogramas das inclusões primárias, sugere que as mesmas foram afetadas por fluidos posteriores mais frios, de menor salinidade, que se encontram registrados nas inclusões secundárias do fragmento 3C. Os fluidos originais teriam sido, portanto, possivelmente diluídos por soluções posteriores mais frias.
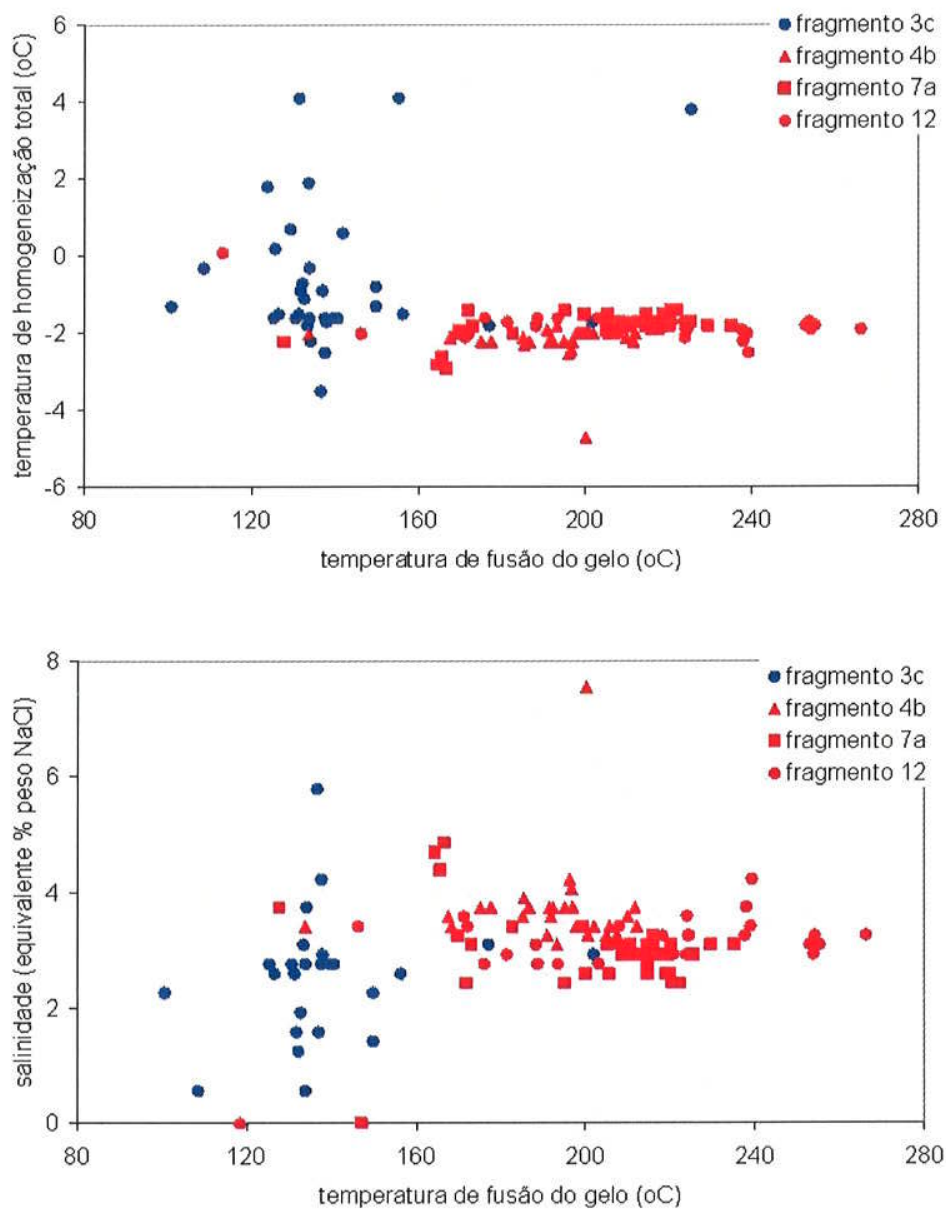

Figura 38. Temperatura de homogeneização total versus temperatura de fusão do gelo, e temperatura de homogeneização total versus salinidade amostra PTI $02 \mathrm{AI}$ (calcita); em vermelho inclusões primárias ou pseudo-secundárias, em azul um conjunto de inclusões possivelmente secundárias.

Considerando-se as modas de salinidade e de temperatura de homogeneização total das inclusões primárias $\left(210-220^{\circ} \mathrm{C} ; 2,5-3,5 \%\right.$ em peso $\mathrm{NaCl}$ equiv.) e das 
secundárias $\left(130^{\circ} \mathrm{C}, 2,0 \%\right.$ em peso $\mathrm{NaCl}$ equiv.), foram calculadas as frações molares dos componentes e das densidades dos fluidos (Tabela 9).

Tabela 9. Fraçăo molar de componentes e densidade de fluidos calculados a partir de dados de microtermometria.

\begin{tabular}{cccccc}
\hline Inclusões Primárias & \multicolumn{1}{l}{} \\
\hline Thtot = Tmin. $\left({ }^{\circ} \mathrm{C}\right)$ & Pmin. (bar) & $\begin{array}{c}\text { Salinidade (\% em peso } \\
\text { do NaCl equiv) }\end{array}$ & $\begin{array}{c}\text { Densidade } \\
\left(\mathrm{g} / \mathrm{cm}^{3}\right)\end{array}$ & $\mathrm{X}_{\mathrm{H} 20}$ & $\mathrm{X}_{\mathrm{NaCl}}$ \\
\hline 210 & 10,8 & 2,5 & 0,8746 & 0,9844 & 0,0156 \\
210 & 10,8 & 3,5 & 0,8833 & 0,9781 & 0,0219 \\
220 & 13,12 & 2,5 & 0,8616 & 0,9844 & 0,0156 \\
220 & 13,12 & 3,5 & 0,8709 & 0,9781 & 0,0219 \\
\hline Inclusões Secundárias & & & & & \\
130 & 2,0 & 0 & 0,9365 & 1 & 0 \\
130 & 2,0 & 2,5 & 0,9531 & 0,9844 & 0,0156 \\
\hline
\end{tabular}

\subsubsection{Inclusões fluidas na auréola de contato do Complexo Granítico Cunhaporanga}

As inclusões fluidas em cristais de quartzo na zona de metarmorfismo de contato do Completo Granítico Cunhaporanga são distintas das inclusões em zonas de cisalhamento. As inclusões da auréola de metamorfismo de contato são carbônicas e aquacarbônicas, enquanto as inclusões nas zonas de cisalhamento são aquosas, praticamente desprovidas de $\mathrm{CO}_{2}$. Os dados microtermométricos completos e os respectivos parâmetros calculados das inclusões individuais das amostras PTi05bac e PTI43AC são apresentados no Anexo Tabela 9 e Anexo Tabela 10, respectivamente. Além disto, as discrepâncias entre as inclusões de cristais coexistentes é maior que nos cristais das zonas de cisalhamento. A representação gráfica dos dados preliminares não conduziu a interpretações coerentes, não sendo portanto aqui apresentada.

Algumas características significativas podem ser ressaltadas nestas amostras

- temperatura de fusão do $\mathrm{CO}_{2}-57,3^{\circ} \mathrm{C}$ na amotra PTI05bac e $-58,5^{\circ} \mathrm{C}$ na amostra PTI43AC, com pequena variação entre as amostras; 
- temperatura de fusão dos clatratos apresenta amplo intervalo de variação, entre $-12 \mathrm{e}$ $9,2^{\circ} \mathrm{C}$ para a amostra PTI05bac e entre $-10,3$ e $9,4^{\circ} \mathrm{C}$ para a amostra PTI43AC, em ambos os casos sem um valor modal definido;

- temperatura de homogeneização do $\mathrm{CO}_{2}$ apresenta amplo intervalo de variação, entre 9,5 e $30^{\circ} \mathrm{C}$ para a amostra PTI05bac e entre $-13,1$ e $29,3^{\circ} \mathrm{C}$ para a amostra PTI43AC, sem um valor modal definido. Apesar da homogeneização ocorrer tanto para o gás como para o líquido, não há uma tendência suficientemente consistente para se localizar uma curva de imiscibilidade;

- temperatura de homogeneização total das inclusões igualmente dispersa em grande intervalo, entre 373 e $450^{\circ} \mathrm{C}$ para a amostra PTI05bac e entre 130 e $574^{\circ} \mathrm{C}$ para a amostra PTI43AC, igualmente sem um valor modal definido.

A grande dispersão dos dados em todos os cristais analisados nestas duas amostras resultou em iścoras incoerentes, sendo que praticamente cada inclusão individual evidenciaria uma história distinta. 


\section{Discussão}

\subsection{A dolomita original e a dolomitização no Grupo Itaiacoca}

O estudo do dolomita deve considerar a frase pouco alentadora de Warren (2000) "...neither trace elements nor isotopic character will determine unequivocally the ultimate origin of an ancient dolomite - both will be reset each time dolomite reequlibrates with a new water". No caso da dolomita, esta incerteza é especialmente pronunciada por tratar-se de um mineral por vezes metaestável e desordenado estruturalmente. Em sua revisão sobre dolomita e dolomitos, Warren (2000) apresenta os discute os modelos de dolomitização de calcários.

Os dolomitos são rochas sedimentares abundantes no registro geológico, formando camadas espessas desde o Proterozóico até o Cenozóico. Entretanto, a formação de dolomita em ambientes recentes é um fenômeno raro, que se dá em ambientes restritos, como fontes termais, lagos salgados e em lamas de lagunas salgadas com intensa evaporação (e.g., Krauskopf e Bird, 1995). A dolomita se forma em sistemas evaporíticos porque precipitação química de gipsita e aragonita aumenta a razão $\mathrm{Mg} / \mathrm{Ca}$ da água remanescente; estas salmouras densas ricas em $\mathrm{Mg}$ e aquecidas percolam sedimentos calcários, dolomitizando os durante ou logo após a sua diagênese. A facilidade de recristalização dos carbonatos, incluindo a dolomita, faz com que a dolomitização seja um fenômeno recorrente, com a superposição de tipos texturais e composicionais distintos em cada estágio (e.g., Reinhold, 1998; Azmy et al., 2001). Vasconcelos et al. (1995) e Vasconcelos e McKenzie (1997) descreveram a formação direta de dolomita em ambientes anóxicos hipersalinos, onde tanto a precipitação como a diagênese são favorecidas pela atividade de bactérias metabolizadoras de enxôfre. Estas bactérias permitiram a a formação de dolomita ordenada em laboratório a baixas temperaturas. A cristalização experimental de dolomita sem a intermediação por bactérias não é possível, sendo que os experimentos geram sólidos desordenados, possivelmente devido à lenta cinética de cristalização da dolomita.

Os metadolomitos do Grupo Itaiacoca não estão associadas a sequências evaporíticas e provavelmente foram dolomitizados ainda durante a sua diagênese, pois a dolomitização foi pervasiva e não obliterou as estruturas sedimentares primárias, tais como a estratificação original, oólitos e estromatólitos (Conophyton, Sallun Filho e 
Fairchild, 2004). A presença do estromatólito Conophyton sugere deposição das rochas carbonáticas abaixo da zona de ação das ondas; para exemplares do mesmo gênero no Canadá foi estimada a profundidade de 10 a $100 \mathrm{~m}$.

A dolomitização em ambiente não-evaporítico pode ocorrer através da mistura de água meteórica com águas subterrâneas marinhas, um modelo conhecido como dolomita-dorag (Badiozamani, 1973, in Warren, 2000), que pode levar à formação de grandes volumes de dolomita. Este processo ocorre porque a curva de solubilidade da calcita relação a concentração de $\mathrm{CO}_{2}$ ou salinidade não é linear; quando duas águas saturadas se misturam, a água resultante é insaturada e a calcita, neste caso, fica sujeita à dissolução (Figura 39a,b). As curvas teóricas de saturação de calcita e dolomita definidas em função de misturas em diversas proporções de água do mar e água meteórica se cruzam, formando um campo estreito onde a água é insaturada em relação à calcita, mas saturada em relação à dolomita (Figura 39c); este é o intervalo onde a dolomitização é teoricamente possível. A eficiência deste modelo depende de sistemas hidrológicos estáveis de longa duração e, portanto, sistemas antigos que formaram grandes volumes de dolomita necessitaram de sistemas hidrológicos estáveis mais prolongados qus os observados em sistemas atuais. Este modelo de dolomitização é consistente com a existência de estromatólitos no Grupo Itaiacoca, e também com a associação das rochas carbonáticas com rochas sedimentares terrígenas que, em conjunto, podem indicar ambientes marinhos rasos e costeiros.

Processos de dolomitação tardia, pós-diagenética podem afetar calcários ao longo de fraturas, veios e descontinuidades estruturas, pelo fluxo de soluções portadoras de magnésio. Isto se observa em algumas jazidas de talco formadas a partir de protolito calcários, os quais são afetados por um front de dolomitização anterior à talcificação, como observado nas minas de talco de Ruby Range, EUA (Brady et al., 1998), de Goepfersgruen, Alemanha (Hecht et al., 1999), de Puebla de Lillo, Espanha (Tornos e Spiro, 2000), e de Trimouns e La Porteille, no maciço de St. Barthelemy na França (Boulvais et al., 2006). A dolomitização no Grupo Itaiacoca não está vinculada à talcificação, não havendo feições petrográficas ou de campo atribuíveis a frentes de dolomitização. 

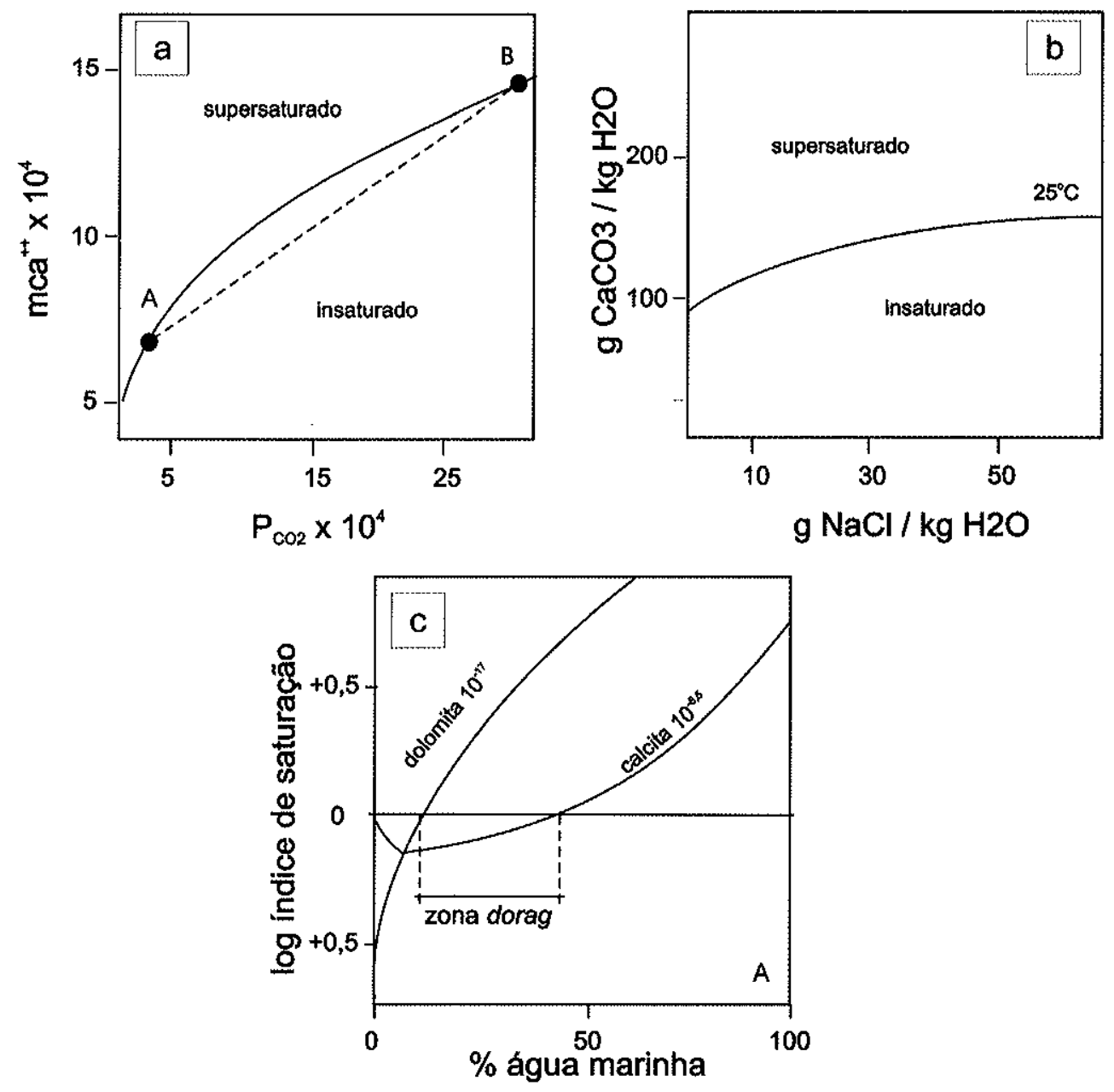

Figura 39. Modelo de formação de dolomita-dorag. (A) Solubilidade da calcita em função da pressão parcial de $\mathrm{CO}_{2}$. Quando as soluções saturadas A e B se misturam, as composições sobre a linha de mistura tracejada $\mathrm{AB}$ são insaturadas em relação a calcita; (B) Solubilidade da calcita em relação à salinidade; (C) Curvas de solubilidade de dolomita e calcita em mistura de água salgada / água doce. A dolomitização ocorre na zona onde a mistura é insaturada em relação à calcita e saturada em relação à dolomita (zona dorag).

Os depósitos de talco hidrotermal Trimouns foram formados a partir de mármores calcíticos cortados por falhas de cavalgamento (Boulvais et al., 2006). Estes mármores sofreram dolomitização, seguida de talcificação. As rochas dolomíticas estão pouco deformadas, inclusive no minério de talco, uma feição semelhante ao talco maciço fino das minas da porção norte do Grupo Itaiacoca. A preservação de estruturas 
sedimentares originais no minério de talco levou Moine (1989) a considerar a seguinte reação:

$2 \mathrm{CaMg}\left(\mathrm{CO}_{3}\right)_{2}+\mathrm{Mg}^{2+}+4 \mathrm{SiO}_{2} \rightarrow \mathrm{Mg}_{3} \mathrm{Si}_{4} \mathrm{O}_{10}(\mathrm{OH})_{2}+2 \mathrm{Ca}^{2+}+4 \mathrm{CO}_{2}$

Neste caso, os fluidos hidrotermais portadores de $\mathrm{Mg}$ seriam água marinha.

Outro fator a ser considerado é a duração dos sistemas hidrotermais, ou seja, o tempo em que os gradientes térmicos e composicionais foram suficientes para manter o fluxo das soluções hidrotermais. Schärer et al. (1999), com base na datação de xenotima e monazita, consideram que o sistema hidrotermal de talcificação em Trimouns, França, teria durado pelo menos $16 \mathrm{Ma}$, com circulação contínua ou episódica de fluidos ao longo de zonas de cisalhamento em regime transtensional e elevado fluxo térmico. A baixa salinidade dos fluidos das inclusões em quartzo e calcita associados ao talco no Grupo Itaiacoca está relacionada à longa duração do sistema hidrotermal de talcificação fluidos na crosta, pois o cálcio e o $\mathrm{CO}_{2}$ liberados para a fase fluida pela decomposição da dolomita e formação de talco teriam sido diluídos pela continuada alimentação do sistema hidrotermal com água quente. $\mathrm{O}$ gradiente geotérmico necessário para manter o sistema hidrotermal foi causado pelos batólitos graníticos em ambos os lados do Grupo Itaiacoca. As grandes zonas de cisalhamento transcorrente seriam canais de circulação de fluidos, possivelmente de origem superficial. Portanto, ainda que os fluidos iniciais de talcificação pudessem estar relacionados ou terem sofrido a influência de fluidos oriundos dos magmas graníticos ou ainda da devolatilização metamórfica das metavulcanossedimentares, é provável que os fluidos circulantes em maior volume e por maior intervalo de tempo tenham deixado sua assinatura nos minerais hidrotermais, considerando a baixa salinidade e baixa $\mathrm{X}_{\mathrm{CO} 2}$ presente nas inclusões fluidas de quartzo e calcita associados ao talco no Grupo Itaiacoca.

A dolomitização do Grupo Itaiacoca, apesar de não dispormos de evidências suficientes para optar por um modelo conclusivo, o que exigiria uma análise estratigráfica detalhada que transcenderia os objetivos deste projeto.

\subsection{Análises mineralógicas}

A composição mineralógica dos minérios e dos tipos litológicos associados é simples, sendo que as fases minerais mais frequentemente associadas ao talco no Grupo Itaiacoca são quartzo, calcita e dolomita. Teores menores de serpentina, tremolita e 
clorita estão presentes nas jazidas de talco xisto. O quartzo é o contaminante mineral mais comum associada ao talco nos minérios, e sua presença se relaciona e veios, vênulas e grãos detríticos do dolomito original. A calcita é o carbonato mais abundante nos minérios de talco, com dolomita praticamente ausente nos minérios prébeneficiados devido à relativa facilidade de separação dos fragmentos de metadolomito em meio ao talco xisto. A presença de serpentina, clorita e tremolita em minérios tipo talco provenientes da área de Itaiacoca indica variações locais na composição dos fluidos hidrotermais. Uma diferença entre os minérios do tipo talco xisto e talco maciço fino, pois estes não contêm tremolita e serpentina.

Shin e Lee (2002) descrevem a formação de jazidas de talco por retrometamorfismo de tremolita em zonas de metamorfismo de contato de rohas graníticas sobre protolitos dolomíticos. No caso específico descrito pelos autores, os altos teores de tremolita no minério levaram à progressiva diminuição da produção destas jazidas. Na auréola de contato do Complexo Granítico Cunhaporanga sobre o Grupo Itaiacoca houve a formação de talco por processo semelhantes, sem entretanto formar jazidas. A presença de tremolita em meio aos minérios de talco, particularmente nos talco xistos em zonas de cisalhamento, está relacionada a variações na composição dos fluidos hidrotermais, sem um controle perceptível até o momento.

As tentativas de análise quantitativa de fases e análise estrutural do talco de distintos contextos geológicos no Grupo Itaiacoca por difratometria de raios $\mathrm{X}$ pelo método de Rietveld não lograram êxito, dada a significativa discordância entre a estrutura dos critais de talco do Grupo Itaiacoca e as estruturas disponíveis na literatura (Gruner, 1934; Rayner e Brown, 1973; Perdikatsis e Burzlaff, 1981). Os dados difratométricos de raios $\mathrm{X}$ de alta resolução coletados para este fim permitiram observar a existência de diferenças entre amostras de talco de diferentes colorações e cristalinidade, entretanto a quantificação destas diferenças não foi possível pela mencionada divergência entre as amostras analisadas e as estruturas disponíveis na literatura. A flagrante diferença entre os difratogramas observados e as estruturas disponíveis torna inviável a quantificação das diferenças cristalográficas entre as amostras de talco analisadas.

Um projeto de refinamento da estrutura do talco para a proposição de um novo modelo foi submetido ao Laboratório Nacional de Luz Síncrotron (LNLS Campinas) no início de 2008. A análise quantitativa de fases pela método de Rietveld em amostras de 
minérios de talco (Picolo, 2002) e de misturas conhecidas de talco + calcita + quartzo + tremolita (Antoniassi, 2003) não atingiu resultados satisfatórios, possivelmente em parte pela inadequação dos modelos estruturais de talco utilizados. Além disto, a análise difratométrica é fortemente afetada pela anisotropia de forma que pode levar a uma orientação preferencial dos cristais no porta-amostras. Este efeito é particularmente intenso no caso das amostras de minérios de talco, onde os principais minerais presentes apresentam forte tendência a orientação preferencial segundo planos de clivagem (talco $\{001\}$; dolomita $\{2-1-11\}$; anfibólio $\{110\})$.

A composição química das fases analisadas também se revelou limitada, pois a maioria dos minerais relacionados à talcificação têm composição muito próxima às respectivas composições ideais puras dos membros extremos de séries de soluções sólidas. O talco do Grupo Itaiacoca tem composição muito próxima a da fórmula ideal, sendo praticamente idento de substituições relevantes nos seus sítios catiônicos. Elementos menores mencionados na literatura $(\mathrm{Cr}, \mathrm{Zn}, \mathrm{Ni}, \mathrm{V}, \mathrm{Ti}$, e.g. El-Sharkawy 2000) que podem indicar processos encontram-se em teores abaixo dos limites de detecção nas condições analíticas utilizadas na microssonda eletrônica. A única variação composicional perceptível no talco é a substituição de uma pequena fração de Si por $\mathrm{Al}$ no sítio tetraédrico, sendo que o talco de talco xisto apresenta as mais elevadas proporções catiônicas de $\mathrm{Al}$, enquanto o talco do minério de talco maciço fino apresenta tendência semelhante, mas com proporção de Al mais restrita, e o talco em fraturas em metadolomito incipientemente talcificado é praticamente isento de $\mathrm{Al}$. Este quadro reflete a proporção de fluidos envolvida em cada um dos casos, pois os talco xisto das zonas de cisalhamento se situam nos principais canais de percolação de fluidos hidrotermais na região. Os minérios de talco maciço fỉno representam sistemas com percolação menos pronunciada de fluidos e com teores mais reduzidos de talco nos minérios. As fraturas em metadolomitos incipientemente talcificados são os sistemas formadores de talco com menor percolação de fluido, onde a talcificação se deu ao longo de planos de dimensões reduzidas e espessuras milimétricas. $O$ teor de alumínio parece ser, ao menos do Grupo Itaiacoca, um potencial indicador da disponibilidade de fluidos de origem externa nos sistemas de talcificação. Em rochas desprovidas de alumínio como os metadolomitos originais do Grupo Itaiacoca, a entrada de alumínio requer a percolação de fluidos de origem externa. Uma explicação análoga pode ser 
aplicada à presença de clorita e serpentina nos minérios de talco xisto, pois ambas as fases apresentam teores de alumínio superiores ao do talco coexistente.

A tremolita é o mais abundante mineral índice nos mármores dolomíticos na auréola de contato com o Complexo Granítico Cunhaporanga, além de ocorrer em raros cristais em talco xistos nas zonas de cisalhamento. A tremolita em talco é mais próxima da formula ideal do mineral do que a presente no mármore dolomítico, a qual apresenta proporções de $\mathrm{Al}$ total, $\mathrm{Fe}$ e de $(\mathrm{Na}+\mathrm{K})$ mais elevadas que na tremolita de talco xisto. Estas diferenças parecem apontar novamente para um sistema mais aberto e de mais alta temperatura no metamorfismo de contato em comparação com o metamorfismo ocorrido nas zonas de cisalhamento.

$\mathrm{O}$ aspecto mais relevante registrado na composição química dos minerais do Grupo Itaiacoca é a sensibilidade à temperatura da distribuição de $\mathrm{Ca}$ e $\mathrm{Mg}$ em carbonatos. A tentativa de aplicação da composição de pares coexistentes dolomitacalcita (e.g. Anovitz e Essene 1987; Letargo et al., 1995) redundou em resultados incoerentes, inclusive com temperaturas inexistentes, da ordem de centenas de graus centígrados negativos. Estas discrepâncias se devem à dificuldade em identificar critérios texturais que comprovem que calcita e dolomita estejam em equilíbrio.

Optou-se, portanto, pela estimativa das temperaturas de talcificação através da fração molar de $\mathrm{MgCO}_{3}$ na calcita metamórfica coexistente com dolomita (Puhan, 1995). As temperaturas de cristalização de calcita coexistente com dolomita em amostras do Grupo Itaiacoca foram calculadas com bases na fração molar de $\mathrm{MgCO}_{3}$ em calcita são apresentados na Figura 40. Dada a dispersão de cada amostras, foram consideradas como mais representativas as temperaturas máximas em cada caso, porque eventos superpostos de menor temperatura tendem a formar cristais de calcita mais puros, com menores teores de $\mathrm{Mg}$. A calcita em minérios tipo talco xisto apresentou valores máximos de temperatura variando de $220^{\circ}$ a $400^{\circ} \mathrm{C}$, enquanto a calcita em minérios do tipo talco maciço fino apresentaram temperaturas inferiores, entre $230^{\circ} \mathrm{e}$ $340^{\circ} \mathrm{C}$. Os teores mais elevados de $\mathrm{Mg}$ foram analisados em calcita presente em mármores na auréola de metamorfismo de contato com o Complexo Granítico Cunhaporanga, com temperaturas estimadas de $250^{\circ}$ a $503^{\circ} \mathrm{C}$.

Temperaturas calculadas em $<200^{\circ} \mathrm{C}$ foram obtidas em praticamente todas as amostras. Esta dispersão intra- e inter-grãos representa provavelmente o reequilíbrio tardio da calcita, após o pico metamórfico em cada contexto. A dispersão dos valores 
sugere a existência de domínios de exsolução submicroscópicos de dolomita, não detectáveis por microscopia óptica ou eletrônica de varredura. Em rochas metacarbonáticas da auréola de contato de uma intrusão granítica, Cook e Bowman (1994) descreveram variação composicional intergrãos mais acentuada, sugerindo reequilíbrio retrógrado grão a grão. Os autores consideram que apenas os teores mais elevados de $\mathrm{Mg}$ sejam representativos das temperaturas do pico metamórfico. As variações nos teores de $\mathrm{Mg}$ em cristais de calcita de uma mesma amostra sugerem reequilíbrio das composições representativas das temperaturas mais elevadas em consequiência de processos metamórficos evanescentes, de temperaturas mais baixas. Entretanto, a identificação deste reequilíbrio tardio é inviável por critérios texturais.

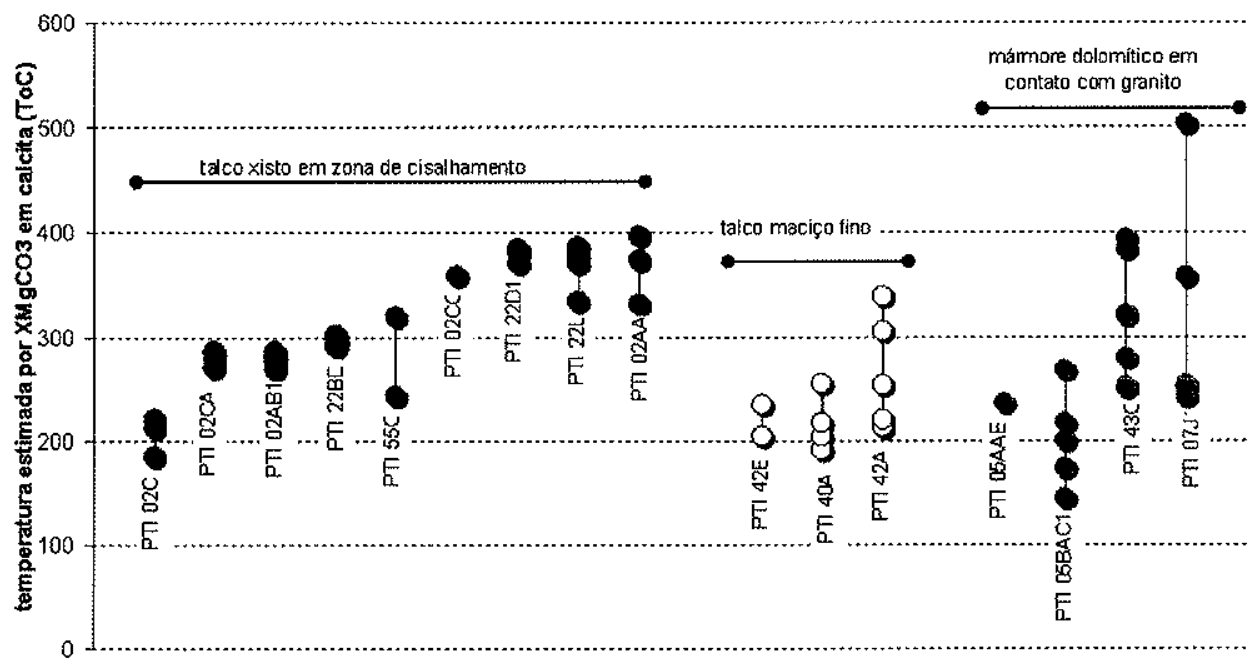

Figura 40. Geotermometria de carbonatos a partir de $\mathrm{X}_{\mathrm{Mg}}$ em calcita coexistente com dolomita, segundo equação de Puhan (1995).

\subsection{Metamorfismo e talcificação no Grupo Itaiacoca}

Mesmo não havendo consenso quanto à estratigrafia e à geocronologia do Grupo Itaiacoca, é possível estabelecer uma sequência relativa dos eventos metamórficos que afetaram estas rochas (Figura 41). No Ciclo Brasiliano ocorreu metamorfismo regional em fácies xisto verde, zona da clorita, e localmente zona da biotita, e deformação em 
dobras abertas, não tendo causado transformações mineralógicas significativas nos metadolomitos. Os epiśdios metamórficos seguintes, ainda no Neoproterozóico, foram concentrados nas bordas do Grupo Itaiacoca. A sudeste houve o desenvolvimento da zona de cisalhamento transcorrente de Itapirapuã, no contato com o Complexo Granítico Três Córregos, não sendo conhecidos registros de metamorfismo termal associado. Na borda noroeste do Grupo ocorreu metamorfismo termal e metassomático no contato com o Complexo Granítico Cunhaporanga. Finalmente, com o soerguimento do Arco de Ponta Grossa no Cretáceo, ocorreu a intrusão de diques de diabásio que causaram metamorfismo termal de dimensões reduzidas sobre as rochas metassedimentares. As relações de campo no Grupo Itaiacoca indicam claramente que o principal episódio de talcificação esteve vinculado a cisalhamento transcorrente e hidrotermalismo associado na borda sudeste do Grupo. As principais jazidas da região situam-se sobre as ramificações da zona de cisalhamento de Itapirapuã, na região de Itaiacoca, onde o minério é talco xisto com foliação anastomosada, lentes de metadolomito, concentrações localizadas de calcita e ocasionalmente tremolita interplanar. O outro tipo de minério de talco, do tipo maciço fino, abundante na região de Abapã e Socavão, é um minério com baixo teor de talco. Este minério situa-se em zonas fraturadas, provavelmente relacionadas às bordas das zonas de cisalhamento transcorrente.

Os trabalhos pioneiros sobre a talcificação de dolomitos devem-se a Bowen (1940) e Tilley (1948), que abordaram rochas dolomíticas silicosas afetadas por fluidos aquosos. A formação de grandes volumes de talco a partir de dolomitos requer a percolação de fluidos aquosos em volume suficiente para promover o aporte de $\mathrm{SiO}_{2}$ e a retirada de $\mathrm{Ca}$ e $\mathrm{CO}_{2}$.

As estimativas das condições de temperatura, pressão e fração molar de $\mathrm{CO}_{2}$ do fluido de talcificação são dificultadas pelas divergências existentes entre as curvas de equilíbrio do sistema $\mathrm{MgO}-\mathrm{SiO}_{2}-\mathrm{CaO}-\mathrm{H}_{2} \mathrm{O}-\mathrm{CO}_{2}$ disponíveis na literatura. Trabalhos mais antigos (Gordon e Greenwood, 1970; Skippen, 1974; Slaughter et al., 1975; Rice, 1977; Eggert e Kerrick, 1981) fornecem campos de estabilidade determinados experimentalmente, que divergem entre si e em relação aos trabalhos mais recentes (Evans e Guggenheim, 1988; Spear, 1993; Holness, 1992), onde as curvas de equilíbrio são calculadas a partir de conjuntos de dados termodinâmicos internamente coerentes. Há divergências quanto à influência da pressão total sobre o campo de estabilidade da associação talco+calcita. Skippen (1974) e Skippen e Trommsdorff (1986) apresentam 
resultados experimentais indicando contração do campo de estabilidade de talco+calcita com a diminuição da pressão total, enquanto que Slaughter et al. (1975) chegam a resultado oposto, onde o campo de estabilidade seria maior a pressões menores.

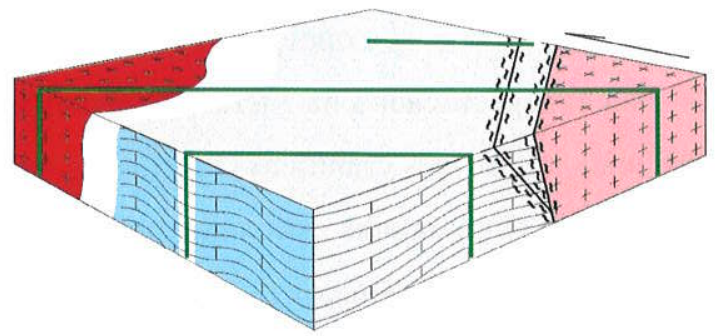

\section{Cretáceo}

colocação dos diques de diabásio

no Arco de Ponta Grossa

metamorfismo termal II

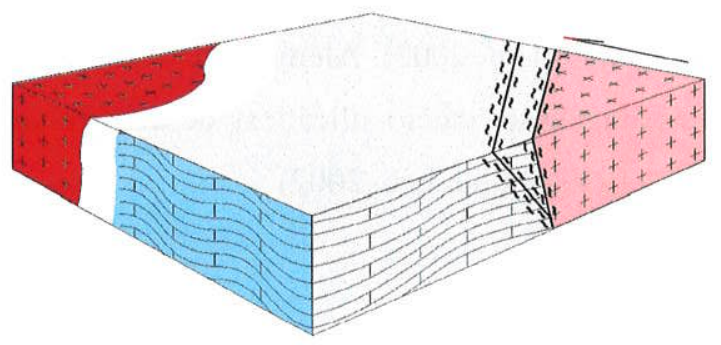

Neoproterozóico - Ciclo Brasiliano colocação do Granito Cunhaporanga metamorfismo termal I

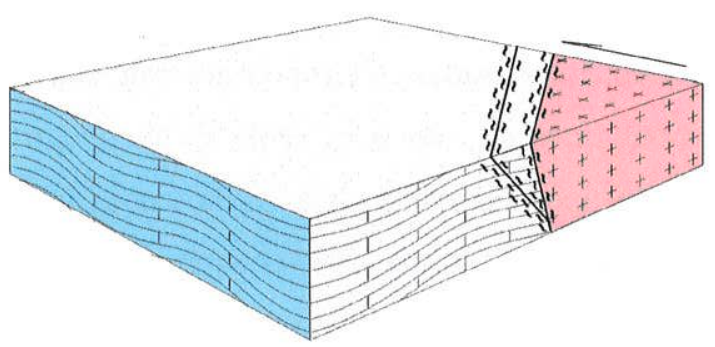

Neoproterozóico - Ciclo Brasiliano metamorfismo regional de baixo grau e dobras abertas colocação do Granito Três Córregos desenvolvimento de zonas de cisalhamento transcorrente

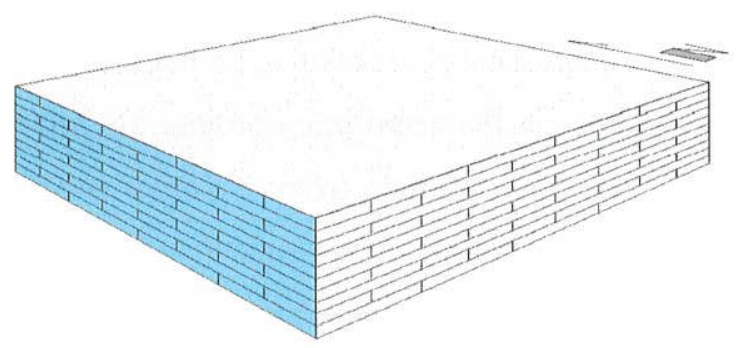

Meso- a Neoproterozóico sedimentação

Figura 41. Modelo simplificado da evolução geológica do Grupo Itaiacoca na região do Arco de Ponta Grossa, Paraná. 
A maioria dos depósitos de talco descritos na literatura está relacionada a rochas dolomíticas associadas a zonas de cisalhamento de amplitude regional (Blount e Vassiliou, 1980; Prochaska, 1989; Anderson et al., 1990; Prochaska et al., 1992; Schandl et al., 1999; Hecht et al., 1999; Tornos e Spiro, 2000, Shin e Lee, 2002; Boulvais et al., 2006), sendo menos frequentes os estudos de jazidas ligadas a rochas metaultramáficas (e.g. El-Sharkawy, 2000). A origem e as condições físico-químicas dos fluidos de talcificação em geral são pouco especificados na literatura disponível. Em alguns casos, a fonte dos fluidos é atribuída a intrusões graníticas (Prochaska et al., 1992; El-Sharkawy, 2000; Shin e Lee 2002). As temperaturas estimadas por meio de inclusões fluidas, isótopos estáveis ou equilíbrios termodinâmicos de reações minerais são inferiores a $500^{\circ} \mathrm{C}$ e as frações molares de $\mathrm{CO}_{2} \mathrm{em}$ geral são baixas $\left(175\right.$ a $350^{\circ} \mathrm{C}$ Prochaska et al., 1992; Tmax $<500^{\circ} \mathrm{C}$ e $\mathrm{X}_{\mathrm{CO} 2}<0,2$ Schandl et al., 1999; 250 $400^{\circ} \mathrm{C}$, baixa $\mathrm{X}_{\mathrm{CO} 2}$ Hecht et al., $1999 ; 380-400^{\circ} \mathrm{C}$ Shin e Lee, 2002). Além disto, a talcificação pode ser retrometamórfica, sobreposta a paragêneses cálcio-silicáticas de temperaturas mais elevadas (Puhan, 1995; Schandl et al., 1999; Shin e Lee, 2002).

\subsubsection{Metamorfismo dinâmico-hidrotermal}

As zonas de cisalhamento transcorrentes que cortam o Grupo Itaiacoca, tanto em sua borda sudeste como nas suas porções internas, são o controle de campo mais evidente para as mineralizações de talco do tipo talco-xisto. A associação das jazidas com falhas de cavalgamento (Lima e Dardenne, 1987; Lima, 1993) não foi confirmada, pois não foram observadas zonas de cisalhamento de baixo ângulo na região meridional do Grupo Itaiacoca.

A talcificação do Grupo Itaiacoca foi controlada pelo fluxo de grande volume de fluido aquoso $\left(\mathrm{X}_{\mathrm{CO} 2} \cong 0\right)$ ao longo das zonas de cisalhamento transcorrente. $\mathrm{O}$ fluxo de soluções hidrotermais foi propiciado pelo alto fluxo térmico local, devido à presença dos dois batólitos graníticos neoproterozóicos que delimitam o Grupo Itaiacoca. Além disto, o fluxo pode haver sido controlado também por bombeamento tectônico através de zonas sucessivas de dilatação e constrição migrantes (Pili et al., 2002). Este fluido hidrotermal foi responsável pelo aporte de sílica e água e pela remoção de cálcio e $\mathrm{CO}_{2}$ durante a talcificação, e também pelo estabelecimento das condições térmicas 
necessárias para que as reações metamorficas ocorressem. A percolação pelos fluidos nos planos de cisalhamento ocorreu sob regime dúctil durante a talcificação, o qual transicionou para um regime mais rúptil nas bordas e nos estágios finais do desenvolvimento destas zonas. Quase simultaneamente, em regiões marginais às zonas de deformação dúctil, ocorreu brechação e venulação em metadolomitos não diretamente afetados pelo cisalhamento dúctil. A formação do talco deve ter ocorrido pela reação

$$
3 \mathrm{CaMg}\left(\mathrm{CO}_{3}\right)_{2}+4 \mathrm{SiO}_{2(\mathrm{aq})}+\mathrm{H}^{+}=\mathrm{Mg}_{3} \mathrm{Si}_{4} \mathrm{O}_{10}(\mathrm{OH})_{2}+3 \mathrm{Ca}^{2+}{ }_{(\mathrm{aq})}+6 \mathrm{CO}_{2}
$$

onde a dolomita reage com o fluido aquoso portador de sílica, produzindo talco e calcita, e liberando $\mathrm{CO}_{2}$ para a fase fluida (e.g. Moine et al., 1989).

A composição, temperatura e condições físico-químicas do fluido mineralizante nas jazidas de talco xisto e nas talcificações incipientes marginais foram estimadas a partir das observações de campo, das análises petrográficas, de química de rocha total e de química mineral, em particular o teor de $\mathrm{Mg}$ em calcita, utilizado como geotermômetro. $\mathrm{O}$ fluido mineralizante foi uma solução aquosa rica em sílica, com temperaturas máximas da ordem de 400 a $420^{\circ} \mathrm{C}$, estimado através de $\mathrm{X}_{\mathrm{Mg}}$ em calcita coexistente com dolomita (Puhan, 1995).

A composição do fluido aquoso foi externamente controlada, com um mínimo de tamponamento pelas reações metamórficas que promoveu. As razões fluido-rocha estimadas foram altas, considerando-se o volume de talco formado, com tamponamento da composição do fluido pelas reações metamórficas manifestando-se apenas localmente pelo surgimento de tremolita. Os cálculos geotermométricos preliminares indicaram a existência de cristais de calcita formados a temperaturas entre $<200 \mathrm{e}$ $400^{\circ} \mathrm{C}$, que sugerem reequilíbrio sob condições mais brandas após o pico de talcificação. Os veios de quartzo associados aos talco xistos representariam aporte de sílica posterior ao pico térmico do sistema, não tendo havido condições para sua reação com a dolomita e formação de talco.

A calcita foi uma fase transitória no talco xisto, formando porfiroblastos lenticulares, $\mathrm{e}$ franjas em veios de talcificação incipiente, mas desaparecendo nas faixas completamente talcificadas. Diversos autores (Luce et al., 1985; Fein e Walther, 1987; Shin e Lee, 2002) constataram que a fase fluida aquosa de sistemas sílico-magnesianos formadores de talco apresenta alta razão $\mathrm{Ca} / \mathrm{Mg}$, pois o $\mathrm{Mg}$ tem coeficiente de partição 
favorável às fases sólidas. Esta razão aumenta com o decréscimo da temperatura, visto que o $\mathrm{Ca}$ é preferencialmente lixiviado a temperaturas decrescentes, o que explicaria a perda preferencial de $\mathrm{Ca}$ em relação ao $\mathrm{Mg}$ durante a talcificação.

O talco pode ser um dos principais minerais lubrificantes de zonas de cisalhamento em profundidades sismogênicas, isto porque mantém sua natureza frágil mesmo a altas pressões e temperaturas, e a altas taxas de deformação (Moore e Lockner, no prelo). A crisotila torna-se mais resistente à deformação a temperaturas acima de $150^{\circ} \mathrm{C}$, enquanto que a montmorillonita tende a se desestabilizar acima desta mesma faixa de temperatura. O talco mantém sua fragilidade até os limites de sua estabilidade térmica $\left(800^{\circ} \mathrm{C}\right.$ a $\left.1 \mathrm{GPa}\right)$ e máxima pressão $\left(\sim 5 \mathrm{GPa}\right.$ a $\left.710^{\circ} \mathrm{C}\right)$, sendo que os dados experimentais demonstram que o talco se torna ainda mais frágil quando aquecido. $\mathrm{O}$ efeito lubrificante do talco foi observado em escala de afloramento, onde a formação localizada de talco aparentemente pode provocar uma deformação dúctil no interior de uma zona de falha predominantemente cataclástica (Figura 12).

Os metadolomitos afetados de modo incipiente pelas zonas de cisalhamento contêm talco em planos de estratificação, clivagens espaçadas e redes de fraturas irregulares, que se apresenta frequentemente associado a núcleos de calcita ou a veios de quartzo, sugerindo a infiltração de pequenos volumes de fluido oriundo das zonas de cisalhamento. O caráter inicialmente aquoso da fase fluida é sugerido pela presença frequente de serpentina precursora do talco nos veios submilimétricos, implicando baixa $\mathrm{X}_{\mathrm{CO} 2}$. Com o progresso da reação de talcificação, a composição do fluido pode ter sofrido modificação, apesar da alta razão fluido/rocha inferida. Localmente, os valores de $\mathrm{X}_{\mathrm{CO} 2}$ podem ter sido suficientemente altos para alcançar o ponto invariante Dol-CcQtz-Tlc-Tr (ponto I, Figura 42) durante o progresso das reações metamórficas, quando tremolita se formaria tanto pela reação entre calcita, sílica e talco como diretamente entre dolomita e sílica, explicando a ocorrência localizada de tremolita nos talco xistos e nos metadolomitos incipientemente cisalhados e talcificados.

Em relação às jazidas de talco maciço fino e pulverulento, que forma bolsões irregulares com núcleos remanescentes de metadolomito, o estilo da talcificação sugere uma percolação pervasiva de soluções ao longo de redes de fraturas. Este processo foi mais eficiente onde o microfraturamento mais denso produziu um incremento na porosidade do metadolomito. A porosidade intergranular de rochas carbonáticas é em geral muito baixa, com o fluxo de soluções aquosas controlado por redes de 
microfraturas, particularmente em rochas dolomíticas, que apresentam comportamento mecânico mais rígido (Holness e Graham, 1991; Holness e Fallick, 1997; Holness, 1997). Um modelo plausível para esta situação seria análogo ao proposto por Blount e Vassiliou (1980) para os depósitos de talco de Winterboro, onde a formação do talco seria desvinculada do metamorfismo regional, sendo atribuída à atividade de fluidos hidrotermais ao longo de fraturas nos metadolomitos.

$\mathrm{O}$ minério de talco maciço fino preserva a $\mathrm{S}_{0}$ das rochas carbonáticas, sugerindo uma transformação estática, sem a deformação intensa, como no talco xistos das zonas de cisalhamento. Abundantes veios de quartzo e silicificação dos metadolomitos acompanham este processo de talcificação. A associação mineralógica é simples, incluindo talco e quartzo, além de volumes subordinados de calcita, montmorillonita e saponita, não sendo registrada a presença de tremolita. Apesar da origem deste fluido não ser conhecida, parece razoável considerar a hipótese de que seja oriundo das zonas de cisalhamento transcorrente, tendo sido injetado através das suas várias ramificações que permeiam o Grupo Itaiacoca. A origem dos depósitos de talco fino maciço está, portanto, relacionada à infiltração de fluido hidrotermal com sílica em solução ao longo de densas redes de fraturas nos metadolomitos, com formação do talco e remoção total do cálcio e $\mathrm{CO}_{2}$. Este processo foi mais eficiente onde o microfraturamento mais denso aumentou a porosidade do metadolomito, e menos eficiente nas regiões mais onde a percolação restrita teria permitido a retenção de parte do cálcio e do $\mathrm{CO}_{2}$ na forma de calcita.

Não parece possível a realização de balanços de massas, pois não há elementos de referência que tenham permanecido inalterados ao longo do proesso. Dentre os elementos maiores, o Mg é o menos móvel, mas é difícil avaliar se sofreu remobilização nos processos de hidratação, silicificação, descarbonatação e descalcificação (e.g. Anderson et al 1990). Os demais elementos analisados apresentam distribuição irregular na suite em estudo ( $\mathrm{Al}, \mathrm{Fe}$ ) ou ocorrem em teores inferiores ou próximos aos limites de detecção dos métodos analíticos usados ( $\mathrm{Ba}, \mathrm{V}, \mathrm{Y}, \mathrm{Zr}$ ). Elementos traço como $\mathrm{Co}, \mathrm{Cr} \mathrm{e}$ $\mathrm{Ni}$, considerados por como relativamente imóveis (Shin e Lee, 2002) não foram determinados nas análises de rocha total executadas.

A relação fluido:rocha volumétrica ou em massa é relevante em sistema hidrotermais como o de talcificação do Grupo Itaiacoca. Uma aproximação da razão fluido:rocha mínima pode ser feita considerando-se a solubilidade do quartzo em 
soluções aquosas, numa faixa de temperatura e pressão próximas às estimadas para o processo em questão. Este é apenas um cálculo de referência, para indicar a ordem de grandeza da relação fluido:rocha mínima. A manutenção do gradiente geotérmico após a talcificação total e a existência de permeabilidade ao longo de planos de cisalhamento e de fraturas garantem que a razão fluido:rocha final do sistema seja muito superior a esta estimativa. A solubilidade do quartzo é um parâmetro importante na compreensão dos sistemas hidrotermas e amplamente discutida na literatura, entretanto, sua determinação experimental apresenta diversas limitações inerentes aos procedimentos experimentais, que aumentam os erros principalmente a partir de $370^{\circ} \mathrm{C}$, com a aproximação do ponto crítico da água a baixas pressões (Rimstidt, 1997; Verma, 2000; Wang et al., 2004).

O transporte de sílica em soluções hidrotermais é controlado principalmente pela solubilidade do quartzo (Fournier, 1985). A solubilidade da sílica amorfa é superior à do quartzo, e sua influência na concentração de sílica em soluções hidrotermais é mais notável em sistemas muito rasos ou superficiais. A solubilidade do quartzo e da sílica amorfa aumentam com o aumento da temperatura. Os experimentos para determinação da solubilidade do quartzo são realizados em condições de baixa ou de alta pressão. Sob baixa pressão, ao longo da curva de saturação água-vapor (e.g. Rimstidt, 1997; Verma, 2000 ), os experimentos apresentam resultados consistentes até $374^{\circ} \mathrm{C}$ (ponto crítico da água), após o que os resultados dos vários autores divergem drasticamente. Sob alta pressão em cápsulas confinadas é possível a existência de água líquida em condições supercríticas (Fournier e Potter, 1982), cujos resultados experimentais permitem analogias com situaçõs mais profundas da crosta terrestre.

Para se ter uma aproximação da ordem de magnitude da razão fluido:rocha nos sistemas de talcificação do Grupo Itaiacoca, os cálulos foram feitos considerando a solubilidade do quartzo a temperatura de $400^{\circ} \mathrm{C}$, conforme a geotermometria de carbonatos (item 9.2). As temperaturas de talcificação estimadas a partir do fracionamento de isótopos estáveis, da ordem de 200 a $300^{\circ} \mathrm{C}$ (item 9.4) e as temperaturas de homogeneização total de inclusões fluidas, da ordem de $220^{\circ} \mathrm{C}$, (item 9.5), resultariam em razões fluido:rocha muito superiores, dada a menor solubilidade do quartzo a temperaturas mais baixas. Foram feitas duas aproximações das razões fluido:rocha a $400^{\circ} \mathrm{C}$, uma considerando um sistema de baixa pressão em contato com a superfície da crosta, onde a pressão total seria próxima da pressão hidrostática, e outra em um sistema confinado, com pressão de 2 kbars, considerando que a colocação do 
Complexo Granítico Cunhaporanga se deu a pressão entre 2 e 4 kars (Guimarães et al., 2000).

Em experimentos de baixa pressão, a equação de solubilidade do quarzto em água definida até $400^{\circ} \mathrm{C}$ ao longo da curva de pressão de saturação água-vapor (Verma, 2000 ), indica que a concentração do quartzo seria de $1380 \mathrm{ppm}$. Nestas condições, seriam necessários 314.830 litros de água para converter $1.000 \mathrm{~kg}$ de dolomita em talco, de acordo com a reação já mencionada

$$
3 \mathrm{CaMg}\left(\mathrm{CO}_{3}\right)_{2}+4 \mathrm{SiO}_{2(\text { aq })}+\mathrm{H}^{+}=\mathrm{Mg}_{3} \mathrm{Si}_{4} \mathrm{O}_{10}(\mathrm{OH})_{2}+3 \mathrm{Ca}^{2+}{ }_{(\mathrm{aq})}+6 \mathrm{CO}_{2}
$$

A razão fluido:rocha 315:1 em massa corresponde a uma razão de 897:1 em volume, considerando a densidade da dolomita como sendo $2,85 \mathrm{~g} / \mathrm{cm}^{3}$ e da água como aproximadamente $1 \mathrm{~g} / \mathrm{cm}^{3}$.

Em experimentos a $400^{\circ} \mathrm{C}$ e 2 kbars (Walther e Orville, 1983) a concentração de $\mathrm{SiO}_{2}$ em água pura é dada em termos de molalidade (log $\left.m=-1,392\right)$, que corresponde a 0,040551 moles de $\mathrm{SiO}_{2}$ por $\mathrm{kg}$ de água. Com esta concentração de $\mathrm{SiO}_{2}$ em solução, seriam necessários $178.317 \mathrm{~kg}$ de água para converter $1000 \mathrm{~kg}$ de dolomita em talco, ou seja uma razão fluido:rocha em massa igual a 178:1, correspondendo a uma relação aproximada fluido:rocha em volume de $508: 1$ (densidade da dolomita $=2,85 \mathrm{~g} / \mathrm{cm}^{3}$ e densidade da água $\sim 1 \mathrm{~g} / \mathrm{cm}^{3}$ ).

Para um caso onde a rocha original era um mármore calcítico, que foi dolomitizado e em seguida talcificado, Anderson et al. (1990) apresentam uma estimativa da relação fluido:rocha em volume superior a 600:1, também com base na solubilidade da sílica em água a $400^{\circ} \mathrm{C}$ e $2 \mathrm{kbars}$, e considerando a solubilidade da calcita nestas mesmas condições.

\subsubsection{Metamorfismo de contato I}

O metamorfismo de contato do Complexo Granítico Cunhaporanga sobre os Grupo Itaiacoca ocorreu em níveis crustais relativamente rasos, com pressões entre 2 e 4 Kbar, estimadas com base na profundidade de colocação do granito (Guimarães et al., 2000). O mineral índice mais abundante nos mármores dolomíticos é a tremolita, que pode apresentar "franjas" de calcita (Figura 13d; Figura 23d), sugerindo a reação:

$$
5 \mathrm{CaMg}\left(\mathrm{CO}_{3}\right)_{2}+\mathrm{H}_{2} \mathrm{O}+8 \mathrm{SiO}_{2(\mathrm{aq})}=\mathrm{Ca}_{2} \mathrm{Mg}_{5} \mathrm{Si}_{8} \mathrm{O}_{22}(\mathrm{OH})_{2}+3 \mathrm{CaCO}_{3}+7 \mathrm{CO}_{2}
$$


Nestas rochas, a formação de talco é incipiente e sobreposta à de tremolita, indicando reequilíbrio retrometamórfico. Rara forsterita e diopsídio ocorrem no núcleo de alguns bolsões zonados, alinhados dentro do acamamento complexamente deformado, possivelmente pela evolução do fluido aquoso percolante para composições mais carbônicas. De modo distinto da atividade hidrotermal nas zonas de cisalhamento, neste episódio de metamorfismo de contato a percolação de fluidos foi menor, com fluidos canalizados em dutos estreitos, os quais ficaram preservados na forma dos bolsões (vistos com duas dimensões) de minerais de alta temperatura (Figura 13a,b).

A composição do fluido aquoso, fornecido em volume relativamente restrito pela cristalização do complexo granítico, teria sido eficientemente tamponada pelas reações metamórficas ocorridas nas rochas dolomíticas, deslocando o equilíbrio em direção à curva de equilíbrio entre dolomita-quartzo (sílica)-tremolita-calcita e ao ponto invariante Dol-Cc-Qtz-Tr-Di (ponto II, diagrama T-X $\mathrm{X}_{\mathrm{CO} 2}$, Figura 42), permitindo a blastese de tremolita diretamente a partir do metadolomito percolado por um fluido reativo portador de sílica, e eventualmente até a blastese de diopsídio mesmo sem um aumento significativo de temperatura. Nos casos em que o fluido metamórfico está presente em proporção reduzida e com tempo de residência relativamente longo, o tamponamento da fase fluida seria a regra, não a exceção no metamorfismo das rochas carbonáticas (e.g. Greenwood, 1975). As temperaturas mais altas, de $530^{\circ} \mathrm{C}$, estimadas através de $\mathrm{X}_{\mathrm{Mg}}$ em calcita, foram registradas em mármores dolomíticos com tremolita nesta zona de contato. Pela configuração das curvas de equilíbrio, esta temperatura máxima obtida seria compatível com os campos de estabilidade de forsterita, acompanhada ou não de diopsídio, sendo a associação tremolita-calcita metaestável nestas condições. A formação da forsterita deve ter ocorrido em condições de pico metamórfico, e não necessariamente em presença de fase fluida com alta $\mathrm{X}_{\mathrm{CO} 2}$. Holness (1992) sugere em contaxto geológico similar na ilha de Skye (Escócia), que a fase fluida tenha se manifestado em pulsos discretos, de composição variável, gerando assembléias de minerais metamórficos que não alcançaram equilíbrio termodinâmico interno.

As inclusões fluidas em quartzo e calcita deste contexto corroboram esta possibilidade. Foram detectados teores elevados de $\mathrm{CO}_{2}$, inclusive com a presença de inclusões carbônicas, em contraste com as inclusões fluidas de zonas de cisalhamento, que são aquosas de baixa salinidade e desprovidas de $\mathrm{CO}_{2}$. Nas zonas de cisalhamento, $o$ aporte de água e a disponibilidade de canais foram suficientes para diluir e transportar 
todo $\mathrm{o} \mathrm{CO}_{2}$ gerado na decomposição da dolomita, ao passo que na auréola de contato a situação era distinta, com menor aporte de fluidos e circulação em canais restritos, permitindo a concentração elevada de $\mathrm{CO}_{2}$, que por sua vez controlou a estabilidade de fases na reações metamórficas.

O metamorfismo de contato e hidrotermal associado nas vizinhanças do Complexo Granítico Cunhaporanga não produziu concentrações significativas de talco. $\mathrm{O}$ talco neste caso é de origem retrometamórfica, sobrepondo-se às paragêneses de mais alta temperatura e ocorre em quantidade ínfima (Figura 23d). No distrito de Hwanggrangri, na Coréia do Sul, o metamorfismo de contato sofrido por metadolomitos em torno de uma intrusão granítica foi o principal mecanismo formador das jazidas de talco (Shin e Lee, 2002), onde o talco se formou pelo retrometamorfismo da tremolita. Neste caso particular, a presença de tremolita acabou sendo decisiva para o declínio e abandono da mineração de talco na região.

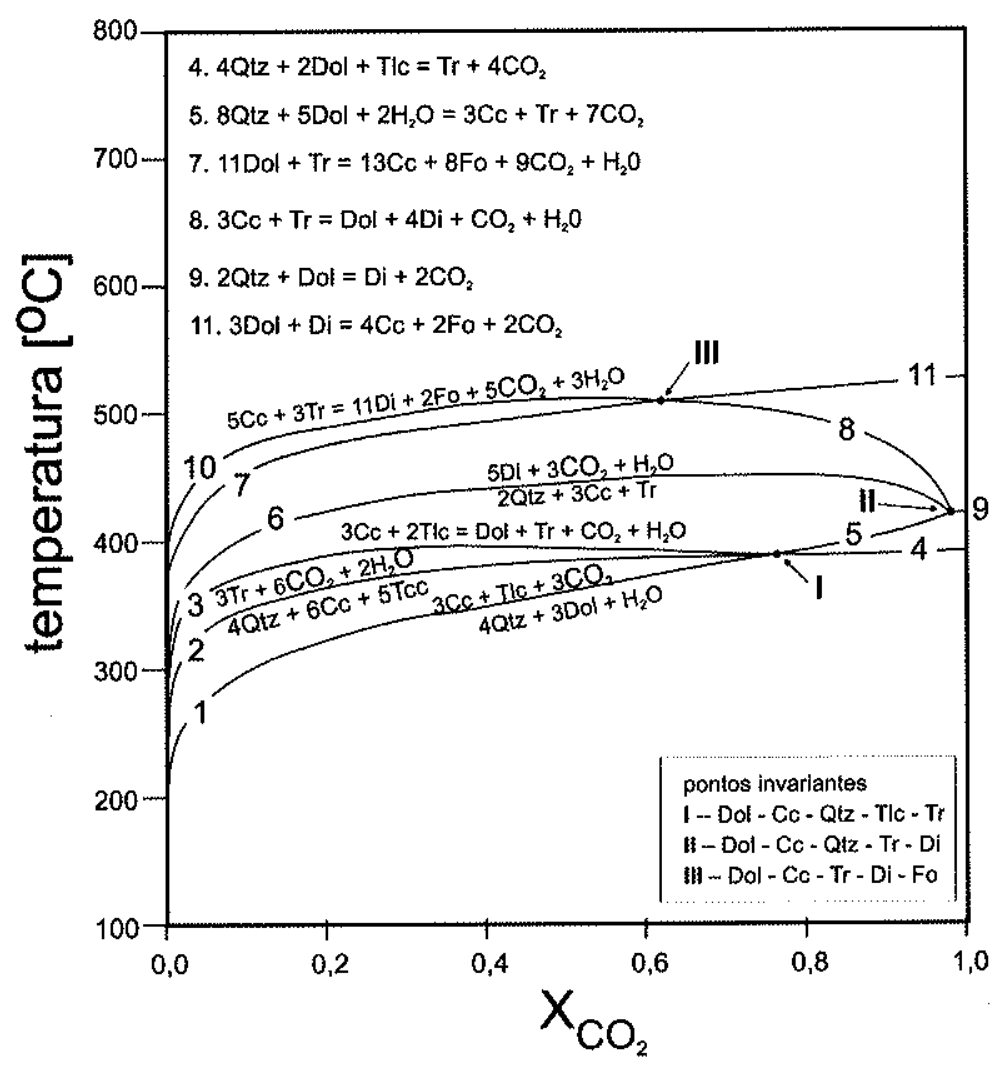

Figura 42. Diagrama de fases pseudo-binário $\mathrm{T}\left({ }^{\circ} \mathrm{C}\right) \times \mathrm{X}_{\mathrm{CO} 2}$ para o sistema dolomita - calcita - quartzo a $0,5 \mathrm{~kb}$ (apud Holness, 1992). 


\subsubsection{Metamorfismo de contato II}

O metamorfismo termal no contato com os diques de diabásio causou recristalização localizada dos metadolomitos, transformando-os em mármores dolomíticos e calcíticos, mas sem levar à formação de talco. Os diques truncam as faixas mineralizadas em talco das zonas de cisalhamento. Nos metadolomitos afetados por este tipo de metamorfismo se desenvolveram geralmente apenas venulações de pequeno porte contendo brucita e serpentina, e localmente forsterita. Nas proximidades de diques possantes ou em megaxenólitos de metadolomitos nos diques, houve a formação de mármores brancos dolomíticos e calcíticos (Figura 16), explorados para uso cerâmico (Reis Neto et al., 2004). Quando estes mármores se apresentam talcosos, trata-se mais provavelmente de metadolomitos previamente talcificados submetidos ao metamorfismo de contato pelos diques, e não de talco formado por consequência deste metamorfismo de contato. Nas demais sequências metassedimentares portadoras de dolomita da Faixa Ribeira (Formações Capiru, Votuverava e Água Clara), cortadas pelos diques de diabásio do Arco de Ponta Grossa, não há registro de talcificação significativa.

A talcificação do Grupo Itaiacoca foi atribuída por Barbosa (1943) e Sobanski $e t$ al. (1984) ao metamorfismo de contato dos diques de diabásio cretáceos do Arco de Ponta Grossa, entretanto este modelo não encontra sustentação nas relações de campo. A frequente relação espacial entre depósitos de talco e diques de diabásio pode ser explicada como um processo de formação de relevo posterior à talcificação, onde os diques protegeriam as rochas metadolomíticas talcificadas da erosão.

\subsection{Isótopos estáveis}

A composição isotópica de carbono e oxigênio dos metadolomitos originais do Grupo Itaiacoca não afetados por processos posteriores ao metamorfismo regional, é similar à composição de mármores e rochas calcárias e dolomíticas, sendo que o metamorfismo regional de baixo grau aparentemente não causou alteração da composição isotópica original. As rochas carbonáticas do Grupo Itaiacoca têm composição isotópica de carbono e oxigênio similares as de outras formações 
carbonáticas neoproterozóicas brasileiras, como as do Grupo Bambuí (Santos et al., 2000 ), $\operatorname{com} \delta^{18} \mathrm{O}_{\mathrm{SMOW}} \geq+25 \%$ e $\delta^{13} \mathrm{C}_{\mathrm{PDB}} \geq+1 \%$.

A partir da composição isotópica inicial dos metadolomitos originais, há uma tendência de diminuição das razões isotópicas de carbono e oxigênio em todas as amostras afetadas por eventos posteriores (Figura 30 ), pois ${ }^{13} \mathrm{C}$ e ${ }^{18} \mathrm{O}$ têm partição preferencial para as fases voláteis (O'Neil et al., 1969; Sheppard e Schwarz, 1970). Entretanto, a variação é mais pronunciada para $\delta^{18} \mathrm{O}$ que para $\delta^{13} \mathrm{C}$, indicando que as soluções hidrotermais são pobres em $\mathrm{CO}_{2}$, em concordância com a discussão do item anterior sobre talcificação em zonas de cisalhamento (9.3.1.). $\mathrm{O}$ amplo intervalo de variação de $\delta^{18} \mathrm{O}\left(14 \%\right.$ ) comparado com o de $\delta^{13} \mathrm{C}\left(3 \%\right.$ ) confirma a baixa $\mathrm{X}_{\mathrm{CO} 2}$, que está de acordo com as os campos de estabilidade de talco e tremolita, e com a composição das inclusões fluidas nos minerais relacionados aos minérios de talco nas zonas de cisalhamento.

A fase carbonática formada juntamente com o talco hidrotermal é a calcita, que está presente tanto nos talco xistos como nos minérios de talco maciço fino. A dolomita sofreu reequilíbrio isotópico e químico pela ação destes fluidos, apresentando um espalhamento menos pronunciado que a calcita para valores menores tanto em $\delta^{18} \mathrm{O}$, como $\delta^{13} \mathrm{C}$. Numa tentativa de apresentar uma aproximação das condições que prevaleceram durante a interação fluido rocha no Grupo Itaiacoca, três modelos de fracionamento isotópico de carbono e oxigênio foram calculados:

a) fracionamento em calcita em rochas talcificadas (Figura 43);

b) fracionamento em dolomita em rochas talcificadas (Figura 44);

c) fracionamento em dolomita em rochas brechadas (Figura 45).

As curvas de fracionamento indicam a composição calculada de carbonatos em equilíbrio com soluções aquosas com temperatura e $\mathrm{X}_{\mathrm{CO} 2}$ fixos e razões fluido:rocha variáveis. A composição inicial da dolomita foi tomada a partir da composição dos metadolomitos originais $\left(\delta^{13} \mathrm{C}=2,4 \% 0 ; \delta^{18} \mathrm{O}=26 \%\right.$ ) e a composição inicial da calcita foi calculada (calcita $\delta^{13} \mathrm{C}=1,3 \% ; \delta^{18} \mathrm{O}=24,2 \%$ ), considerando-se calcita em equilíbrio com a dolomita original a $\mathrm{T}=400^{\circ} \mathrm{C}$, usando-se o fator de fracionamento de Sheppard e Schwarcz (1970). A composição inicial do fluido hidrotermal $\left(\delta^{13} \mathrm{C}=-5 \%\right.$; $\delta^{18} \mathrm{O}=3 \%$ ) foi escolhida procurando-se o melhor ajuste das curvas, sendo os mesmos 
valores adotados por Boulvais et al. (2006) em modelo similar aplicado à talcificação de carbonatos. Detalhes dos cálcudos são fornecidos no capítulo 3 (Materiais e métodos analíticos) e as principais variáveis consideradas em cada caso encontram-se especificados nas legendas das respectivas figuras. A talcificação dos metadolomitos se deu preferencialmente em zonas de cisalhamento, onde o fluxo das soluções hidrotermais é canalizado, favorecendo a persistência de desequilíbrios químicos e isotópicos (Baumgartner e Valley, 2001). A existência de desequilíbrio é praticamente uma regra nestes casos, dada a facilidade de recristalização dos carbonatos. Optou-se, portanto, pelo cálculo de fracionamento isotópico em um sistema aberto com devolatilização tipo Rayleigh.

Os três modelos reproduzem com limitações a dispersão de pontos observada no conjunto das amostras, com uma variação inicialmente mais pronunciada de $\delta^{18} \mathrm{O}$ com $\delta^{13} \mathrm{C}$ praticamente inalterado e mais pronunciado para razóes fluido:rocha mais elevadas, devido à baixa concentração de $\mathrm{X}_{\mathrm{CO} 2}$ considerada no modelo. Os valores escolhidos de $\mathrm{X}_{\mathrm{CO} 2}(0,05$ para talcificação; 0,10 para brechação) são aproximações simplificadas baseadas em relações de campo que indicam percolação muito maior de água nas zonas de cisalhamento e fraturas talcificadas, que nas brechas, e portanto nas brechas $\mathrm{o} \mathrm{CO}_{2}$ liberado por descarbonatação seria diluído em menor grau. Cabe ressaltar que nos carbonatos estão registradas apenas os estágios iniciais de talcificação, pois quando a talcificação é completa não há mais carbonatos no sistema, i.e. a percolação de fluidos hidrotermais possivelmente prossegue até o desaparecimento dos carbonatos, percolando os corpos de talco enquanto o gradiente geotérmico foi suficiente para manter a convecção hidrotermal.

Um fator que não pode ser considerado nos modelos foi a heterogeneidade isotópica dos protolitos (metadolomito original), que influencia fortemente a posição da curva calculada de fracionamento. Uma aproximação mais acurada consideraria diversas curvas de fracionamento que cobrissem toda a amplitude de variação isotópica das rochas original, o que dificultaria a representação gráfica.

O cálculo do fracionamento sofrido pela calcita na talcificação (Figura 43) indica que as composições extremas de calcita hidrotermal, com $\delta^{18} \mathrm{O}$ entre $8 \mathrm{e} 10 \% \mathrm{e}$ $\delta^{13} \mathrm{C} \sim 0 \%$ estão de acordo com as composições previstas para razões fluido:rocha $=5 \mathrm{e}$ $\mathrm{T}=300^{\circ} \mathrm{C}$; composição um pouco menos fracionada estaria de acordo com razões fluido:rocha equivalentes e $\mathrm{T}=200^{\circ} \mathrm{C}$. A calcita associada ao minério de talco maciço 
fino e a calcita de talco xisto têm composição isotópica semelhante, sugerindo que este tipo de minério possa estar relacionado à talcificação ocorrida ao longo das zonas de cisalhamento. Há uma população de amostras entre este extremo e a composição original, sob as curvas calculadas de fracionamento, podendo ser decorrência tanto de heterogeneidade da rocha original como efeito superposto de intemperismo. Este efeito é representado por uma amostra isolada de calcita de talco xisto $\left(\delta^{13} \mathrm{C}=-7,5 \%\right.$; $\delta^{18} \mathrm{O}=$ $25 \%$ o), cuja composição é semelhante à da calcita supergênica, indicando influência superimposta de soluções intempéricas recristalizando fases hidrotermais de mais alta temperatura.

O cálculo do fracionamento isotópico de dolomita (Figura 44) encontrou limitações semelhantes, onde todas as amostras, com exceção de uma, se situam abaixo da curva de fracionamento. $O$ formato geral da nuvem de pontos poderia ser modelado considerando uma concentração de $\mathrm{CO}_{2}$ mais elevada na solução hidrotermal, que reduziria os valores de $\delta^{13} \mathrm{C}$ de modo significativo mesmo a baixas razões fluido:rocha. Entretanto esta possibilidade colide com os dados de inclusões fluidas e com as observações de campo, que revelam que nas zonas de talcificação os fluidos eram praticamente desprovidos de $\mathrm{CO}_{2}$, em se tratanto de um sistema francamente aberto com extensa circulação de água, acarretando diluição extrema do $\mathrm{CO}_{2}$. Seria plausível, portanto, que a origem da discordância entre a curva calculada e os dados esteja na composição inicial de $\delta^{13} \mathrm{C}$ da dolomita original, pois se esta fosse deslocada para valores $2 \%$ inferiores o ajuste da curva seria mais satisfatório. Isto é possível, já que não cohecemos a amplitude da heterogeneidade isotópica das rochas originais, conforme já mencionado anteriormente. Optou-se por manter a composição da dolomita original de acordo com os dados disponíveis, posto que o modelo calculado que visa apontar apenas tendências gerais de evolução do sistema.

As brechas tectônicas são compostas por clastos e matriz essencialmente dolomíticos, sendo que os clastos têm a mesma isotópica do metadolomito original e a matriz apresenta desvio para valores de $\delta^{18} \mathrm{O}$ inferiores, da ordem de 16 a $18 \%$, mas sem alterar os valores de $\delta^{13} \mathrm{C}$ (Figura 32). O cálculo do fracionamento isotópico de dolomita nas brechas (Figura 45) considerou uma maior fração de $\mathrm{CO}_{2}$ no fluido $\left(\mathrm{XCO}_{2}\right.$ $=0,10$ ) e foi permitiu reproduzir as composições das amostras, que são compatíveis com razões fluido:rocha entre 0,5 e 1,0 e temperaturas de 300 e $400^{\circ} \mathrm{C}$. Os carbonatos das brechas têm composição isotópica intermediária entre os metadolomitos originais e 
os carbonatos de talco xistos, que são os mais fracionados isotopicamente. As zonas de maior deformação e percolação de fluidos foram afetadas por pulsos superimpostos de fluidos hidrotermais, enquanto que os veios representam eventos unitários de percolação e selamento de fraturas (Pili et al., 2002). A composição isotópica do fluido durante a formação dos veios pode ter sido tamponada pelo metadolomito, fazendo com que os carbonatos dos veios tenham composição isotópica mais próxima à da rocha original, enquanto que os carbonatos dos talco xistos são isotopicamente mais similares ao fluido hidrotermal. 


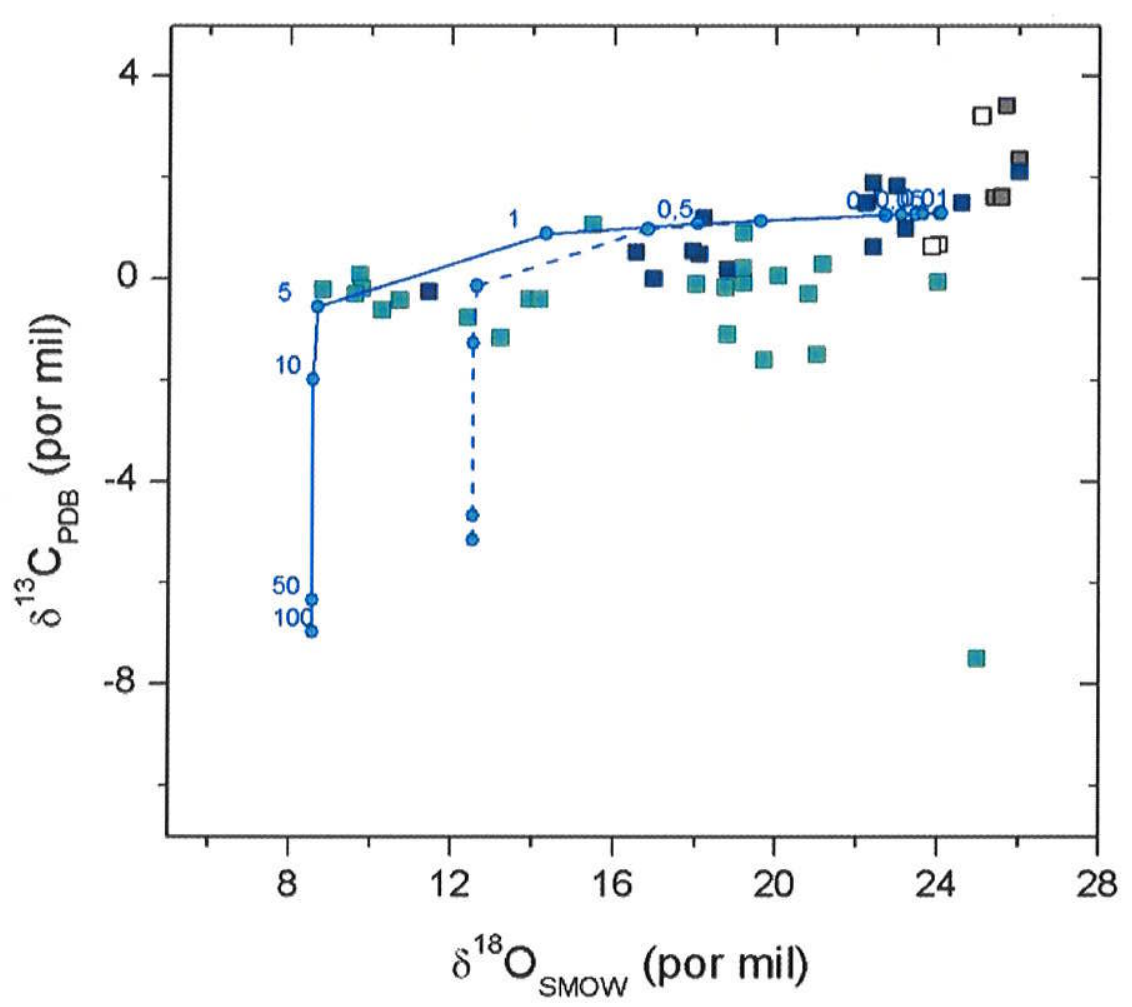

metadolomito original

- dolomita

ㅁ calcita

\section{metadolomito talcificado \\ - dolomita \\ calcita}

fracionamento isotopico de CALCITA

$\rightarrow 300^{\circ} \mathrm{C} ; \mathrm{X}_{\mathrm{CO} 2} 0,05$

$-200^{\circ} \mathrm{C} ; \mathrm{X}_{\mathrm{CO} 2} 0,05$

Figura 43. Curvas calculadas de fracionamento isotópico de carbono e oxigênio de calcita em rochas talcificadas, considerando: $\mathrm{X}_{\mathrm{CO} 2}=0,05$; temperaturas de $300^{\circ} \mathrm{C}$ (curva cheia) e $200^{\circ} \mathrm{C}$ (curva tracejada); composição inicial da calcita $\delta^{13} \mathrm{C}=1,3 \%$; $\delta^{18} \mathrm{O}=24,2 \%$; composição inicial do fluido $\delta^{13} \mathrm{C}=-5 \%$; $\delta^{18} \mathrm{O}=3 \%$. Os números ao longo das curvas representam a razão fluido:rocha. 


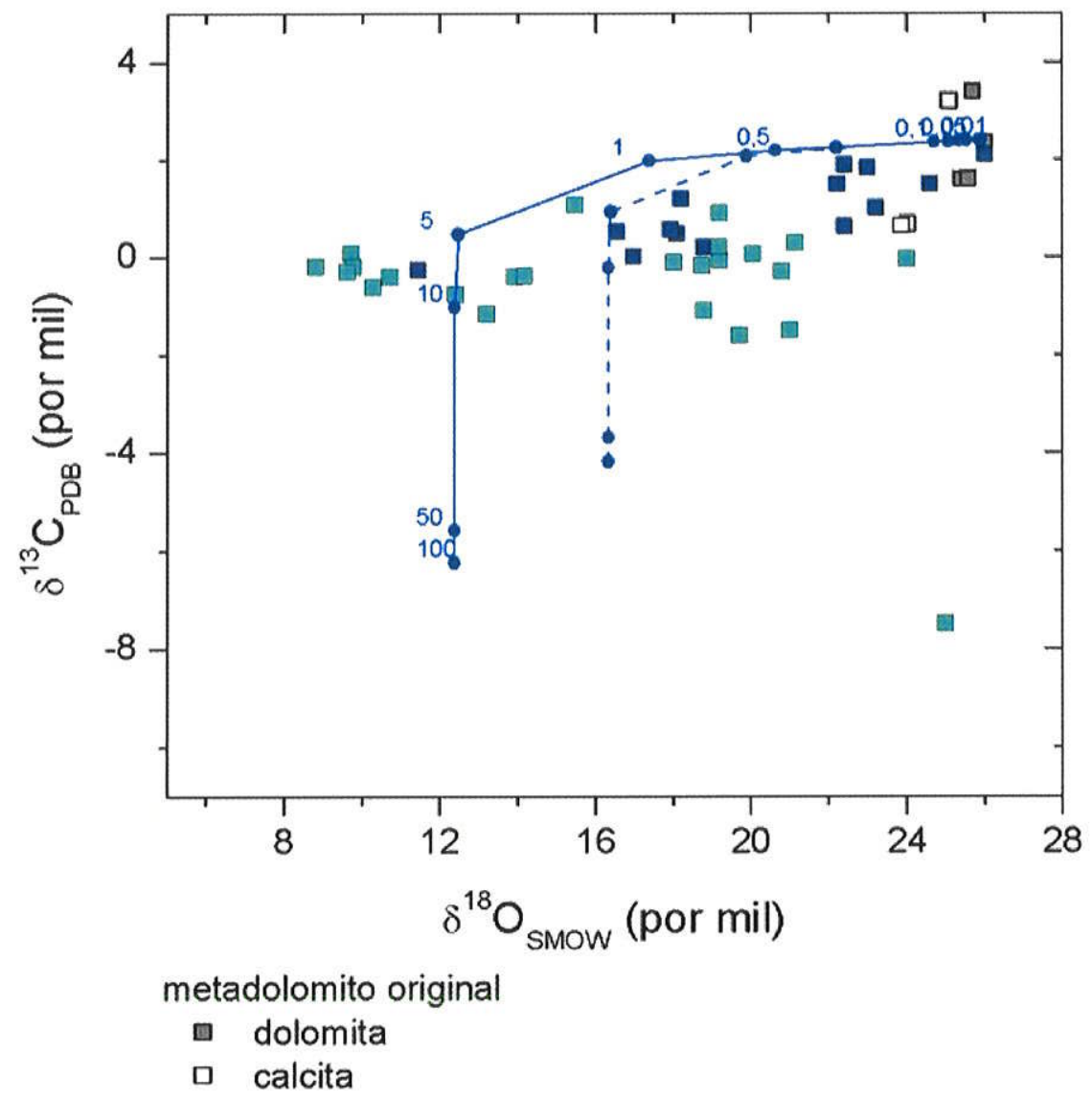
metadolomito talcificado
- dolomita
calcita

fracionamento isotopico de DOLOMITA

$$
\begin{aligned}
& \longrightarrow 300^{\circ} \mathrm{C} ; \mathrm{X}_{\mathrm{CO} 2} 0,05 \\
& \longrightarrow-200^{\circ} \mathrm{C} ; \mathrm{X}_{\mathrm{CO} 2} 0,05
\end{aligned}
$$

Figura 44. Curvas calculadas de fracionamento isotópico de carbono e oxigênio de dolomita em rochas talcificadas, considerando: $\mathrm{X}_{\mathrm{CO} 2}=0,05$; temperaturas de $300^{\circ} \mathrm{C}$ (curva cheia) e $200^{\circ} \mathrm{C}$ (curva tracejada); composição inicial da dolomita $\delta^{13} \mathrm{C}=2,4 \%$; $\delta^{18} \mathrm{O}=26 \%$; composição inicial do fluido $\delta^{13} \mathrm{C}=-5 \%$; $\delta^{18} \mathrm{O}=3 \%$ o. Os números ao longo das curvas representam a razão fluido:rocha. 


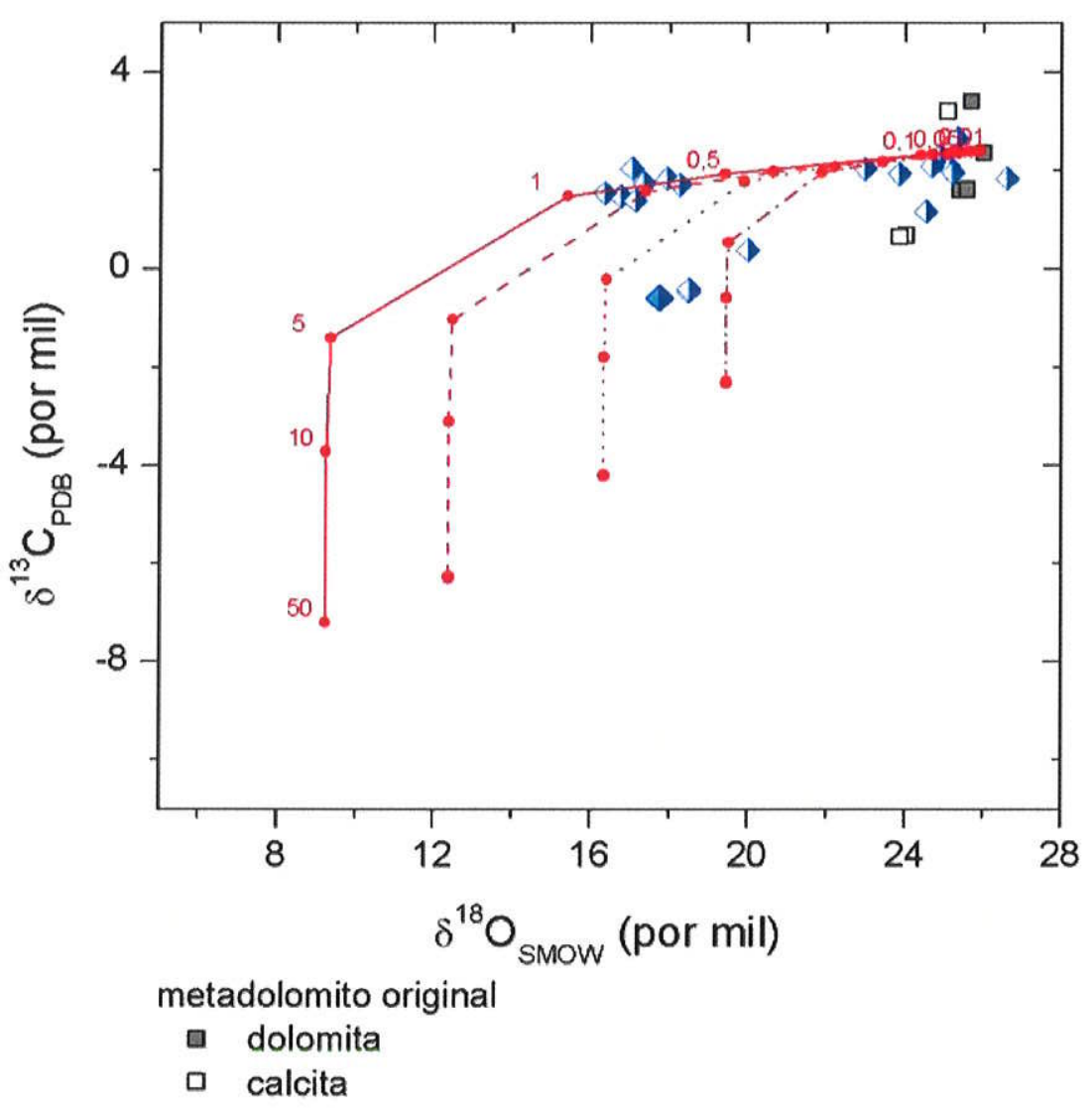

\section{metadolmito brechado \\ - dolomita \\ - calcita}

fracionamento isotopico DOLOMITA

$$
\begin{array}{r}
\longrightarrow 400^{\circ} \mathrm{C} ; X_{\mathrm{CO} 2} 0,10 \\
\cdots 300^{\circ} \mathrm{C} ; X_{\mathrm{CO} 2} 0,10 \\
\cdots 200^{\circ} \mathrm{C} ; X_{\mathrm{CO} 2} 0,10 \\
\because 150^{\circ} \mathrm{C} ; X_{\mathrm{CO} 2} 0,10
\end{array}
$$

Figura 45. Curvas calculadas de fracionamento isotópico de carbono e oxigênio de dolomita em rochas brechadas, considerando: $\mathrm{X}_{\mathrm{CO} 2}=0,10$; temperaturas de $400^{\circ} \mathrm{C}$ (curva cheia); $300^{\circ} \mathrm{C}$ (curva tracejada); $200^{\circ} \mathrm{C}$ (curva pontilhada); e $150^{\circ} \mathrm{C}$ (curva tracejada-pontilhada); composição inicial da dolomita $\delta^{13} \mathrm{C}=$ $2,4 \%$; $\delta^{18} \mathrm{O}=26 \%$; composição inicial do fluido $\delta^{13} \mathrm{C}=-5 \%$; $\delta^{18} \mathrm{O}=3 \%$ o. Os números ao longo das curvas representam a razão fluido:rocha. 
O fracionamento isotópico dos carbonatos formados em ambientes superficiais (calcita, aragonita) apresenta comportamento contrastante com os carbonatos associados à talcificação e à brechação dos metadolomitos. Os processos supergênicos levaram à uma drástica redução de $\delta^{13} \mathrm{C}$, mas mantiveram $\delta^{18} \mathrm{O}$ praticamente inalterado em relação ao metadolomito original (Figura 30). Este fracionamento pode ser explicado pela presença soluções superficiais que interagiram com matéria-orgânica dos solos, cuja composição isotópica de carbono é fortemente negativa.

A existência de calcita em talco xistos com valores de $\delta^{18} \mathrm{O}$ compatíveis com curvas téoricas calculadas para temperaturas da ordem de $100^{\circ} \mathrm{C}$ sugere o reequilíbrio posterior ao pico de talcificação, podendo ainda refletir a maior facilidade da calcita em reagir com soluções aquosas isotopicamente mais pesadas, enquanto que a dolomita se mantém relativamente mais inerte (Sheppard e Schwarcz, 1970).

Todos os depósitos de talco em dolomitos descritos na literatura apresentam a mesma tendência de fracionamento de $\delta^{13} \mathrm{C}$ e $\delta^{18} \mathrm{O}$ para valores menores, pois os fatores de fracionamento (e.g. Sheppard e Schwarcz, 1970) mostram que o $\mathrm{CO}_{2}$ é isotopicamente mais pesado que os carbonatos com ele coexistentes.

Os depósitos de talco hidrotermal Trimouns, associados a dolomitos nos Pirineus, idade Albiana (112-97 Ma) têm composição isotópica $\mathrm{C}-\mathrm{O}$ original e fracionamento com a talcificação similares à de Itaiacoca (Boulvais et al., 2006).

Boulvais et al. (2006) consideram que o desequilíbrio isotópico entre calcita e dolomita possa estar relacionado ao efeito do retrometamorfismo, que teria afetado a calcita em maior intensidade que a dolomita. Os autores também consideram que a evolução isotópica contínua desde o mármore calcítico até os dolomitos e calcita hidrotermal pode ser explicado por um único evento de interação fluido:rocha, com razões fluido:rocha variáveis, havendo um aumento da proporção de fluido desde o mármore calcítico, passando pela rocha dolomitizada, até atingir a calcita hidrotermal associada ao talco.

Anderson et al. (1990) considera que a talcificação em Ruby Range ocorreu na sob volume constante na crosta rígida, em rochas dolomíticas, acima da transição dúctilrúptil. Pseudomorfos de talco substituindo dolomita são visíveis em seção delgada. Assim como no Grupo Itaiacoca, as rochas carbonáticas de Ruby Range são cortadas por diques máficos, não havendo ocorrências de talco a eles associadas. A assembléia 
mineral dominante dos minérios é tc+dol $+c t t c c$, com os acessórios grafita, pirita, $\mathrm{MnO}$, quartzo, serpentina, tremolita e flogopita. Aparentemente há um front de dolomitização que antecedeu a talcificação.

O depósito de talco de Gopfersgrün formado a partir de mármore com níveis calcíticos e dolomíticos, ao longo de zonas de cisalhamento, apresenta dados isotópicos C-O são semelhantes aos de Itaiacoca, mas com valores de $\delta^{18} \mathrm{O}$ um pouco mais baixos (Hecht et al., 1999). A última fase de geração de calcita (cc4) tem composição isotópica semelhante à da aragonita supergênica de Itaiacoca. O principal estágio da talcificação está relacionado à percolação de águas de origem externa, com baixo $\delta^{18} \mathrm{O}$. A faixa de temperaturas, indicada por inclusões fluidas é de 250 a $400^{\circ} \mathrm{C}$. As inclusões fuidas em dolomita relativa ao pico da talcificação têm alta salinidade, na faixa de $25 \%$ peso em $\mathrm{NaCl}$ equivalente, sem a presença de $\mathrm{CO}_{2}$ dissolvido ou clatratos, o que sugere que os fluidos mineralizantes não foram águas meteóricas, mas fluidos formacionais ou salmouras continentais. Os valores reduzidos de $\delta 13 \mathrm{c}$ podem estar relacionados à reação com xistos grafitosos, análogo ao quadro encontrado em Itaiacoca, com filitos grafitosos em contato direto com os mármores talcificados. A composição isotópica da calcita tardia (cc3), com decréscimo de $\delta^{13} \mathrm{C}$ mas com $\delta^{18} \mathrm{O}$ constante como na aragonita de Itaiacoca, sugere um processo tardio a $\mathrm{T}<100^{\circ} \mathrm{C}$ e fluidos dominados por $\mathrm{HCO}^{3-}$ (Ohmoto e Rye, 1979).

No Grupo Itaiacoca, os fluidos permitiram a manutenção da temperatura necessária para que as reações metamórficas ocorressem, sendo que as temperaturas máximas do fluido mineralizante foram estimadas no intervalo entre 400 e $420^{\circ} \mathrm{C}$. Além da temperatura, a presença dos fluidos e a concomitante formação de talco durante a atividade tectônica fizeram com que a deformação se desse em regime dúctil durante a talcificação. Simultaneamente, na periferia das zonas com deformação dúctil, ocorreu deformação rúptil, com brechação e venulação em metadolomitos não talcificados. A presença de brechas nas rochas carbonáticas do Grupo Itaiacoca é disseminada.

\subsection{Inclusões fluidas}

As inclusões fluidas analisadas em dois contextos geológicos contrastantes no Grupo Itaiacoca apresentam características distintas. Nas zonas de cisalhamento, as inclusões fluidas são aquosas e praticamente desprovidas de $\mathrm{CO}_{2}$. As inclusões 
primárias apresentam concentração dos valores de Thtot em torno de 210 a $220^{\circ} \mathrm{C}$ e salinidade $<3,5 \%$ peso $\mathrm{NaCl}$ equivalente, ao passo que as secundárias apresentam Thtot predominante em torno de $130^{\circ} \mathrm{C}$ e salinidade $<2,5 \%$ peso $\mathrm{NaCl}$ equivalente, revelando o arrefecimento do sistema e a progressiva diluição da concentração dos solutos, originalmente já reduzida. A temperatura eutética das inclusões primárias $\left(<-40^{\circ} \mathrm{C}\right)$ sugere a presença de cátions bivalentes no fluido aprisionado (Roedder, 1984; Goldstein e Reynolds, 1994), o que reflete a mobilidade de $\mathrm{Ca}^{2+}$ e $\mathrm{Mg}^{2+}$ no contexto da talcificação. A virtual ausência de $\mathrm{CO}_{2}$ nas inclusões primárias mostra que os fluidos gerados durante a descarbonatação da dolomita, processo fundamental para a formação de talco no Grupo Itaiacoca, foram diluídos no enorme volume de água que percolou as zonas de cisalhamento durante a após o pico da talcificação. Os cálculos de razão fluido:rocha apontam para razões mínimas da ordem de 500:1 (item 9.3.1), o que permite a diluição e o transporte de praticamente todo $\mathrm{o} \mathrm{CO}_{2}$ gerado durante a talcificação.

Os dados preliminares de inclusões fluidas na auréola de contato com Complexo Granítico Cunhaporanga indicam que estas são predominantemente carbônicas e aquocarbônicas, com raras inclusões aquosas. As temperaturas de homogeneização total são mais elevadas que nas zonas de cisalhamento $\left(373\right.$ a $450^{\circ} \mathrm{C}$ ), mas com amplo espalhamento de valores e praticamente sem a preponderância de um valor mais representativo. Esta ampla variação se observa também nas temperaturas de fusão do clatrato, de homogeneização do $\mathrm{CO}_{2}$, sugerindo fortemente a modificação destas inclusões após seu aprisionamento no mineral hospedeiro (quartzo). A temperatura de fusão do $\mathrm{CO}_{2}$ ocorre dentro de um intervalo estreito, entre -57 a $-60,4^{\circ} \mathrm{C}$, e sugere a possível existência de outra fase carbônica gasosa nestas inclusões, como $\mathrm{CH}_{4}$. Entretanto, a confirmação desta possibilidade ainda necessita de estudos complementares.

Apesar dos dados coletados na auréola de contato com o granito ainda serem preliminares e inconclusivos, é evidente a abundância de $\mathrm{CO}_{2}$ neste contexto, constrastando com as zonas de cisalhamento onde houve formação das jazidas de talco. Isto sugere que nas auréolas de contato a circulação de soluções hidrotermais primárias foi menor, consequentemente com menor diluição do $\mathrm{CO}_{2}$ gerado na descarbonatação durante a formação dos silicatos magnesianos (diopsídio, tremolita). 
Os dados publicados de inclusões fluidas em jazidas de talco em rochas carbonáticas são raros na literatura (Moine et al., 1989; Prochaska et al., 1992; Tornos e Spiro, 2000). Além disto, estes estudos apresentam pequeno número de inclusões analisadas, apresentando via de regra grande dispersão de parâmetros e interpretações inconclusivas. Prochaska et al. (1992) analisando veios de quartzo obteve temperatura eutética entre -52 a $-46^{\circ} \mathrm{C}$, salinidade elevada 30 a $38 \%$ peso $\mathrm{NaCl}$ equivalente chegando a formar inclusões com fase sólida, Thtot entre 176 e $310^{\circ} \mathrm{C}$. Moine et al. (1989) obteve igualmente salinidade com ampla faixa de variação $(25$ a $42 \%$ peso $\mathrm{NaCl}$ equivalente), eutético entre -57 e $-52^{\circ} \mathrm{C}$, com conjunto de a inclusões com fases sólidas coexistindo com inclusões sem fases sólidas, e Thtot entre 110 e $305^{\circ} \mathrm{C}$. Tornos e Spiro (2000) analisaram poucas inclusões primárias em dolomita relacionada à talcificação $(n=9)$ obtendo Thtot entre 282 e $314^{\circ} \mathrm{C}$, salinidade entre 9,5 e $10,3 \%$. 


\section{Conclusão}

O Grupo Itaiacoca é composto predominantemente por rochas metadolomíticas de baixo grau metamórfico, que preservam estruturas primárias sedimentares. A dolomitização ocorreu possivelmente no estágio sin-sedimentar ou sin-diagenético, pela ação de mistura de soluções com salinidade contrastante, sem a influência de ambientes evaporíticos, como ocorre em vários casos de dolomitização no registro geológico.

O Grupo Itaiacoca foi submetido a quatro episódios metamórficos, na seguinte ordem: (i) metamorfismo regional de baixo grau, fácies xisto verde - zona da clorita; (ii) metamorfismo dinâmico acompanhado de intensa atividade hidrotermal ao longo de ramificações da Zona de Cisalhamento Itapirapuã no contato com o Complexo Granítico Três Córregos e em ramificações no interior do Grupo Itaiacoca; (iii) metamorfismo termal no contato com o Complexo Granítico Cunhaporanga; (iv) metamorfismo termal de pequena abrangência no contato com diques de diabásio mesozóicos que cortam o Grupo Itaiacoca ao longo do Arco de Ponta Grossa.

A talcificação em larga escala se associou ao metamorfismo hidrotermal nas zonas de cisalhamento e gerou jazidas de talco xistos com foliação anastomosada envolvendo lentes residuais de metadolomito e lentes sintectônicas de calcita. Jazidas de talco maciço fino, de aspecto pulverulento e caracterizadas pela talcificação ao longo de planos de fratura e descontinuidades estruturais, sem alteração significativa de volume, estão associadas a zonas de fraturas periféricas aos sistemas principais de cisalhamento, mas sem a influência direta da deformação milonítica. Há ainda a presença de talco em filmes e vênulas em metadolomitos incipientemente talcificados, também presentes nas bordas de sistemas de talcificação de maior porte. Finalmente, quantidades subordinadas de talco retrometamórfico formaram-se a partir de tremolita na auréola de metamorfismo de contato com o Complexo Granítico Cunhaporanga. Não se observou talco associado aos metadolomitos afetados por metamorfismo regional ou pela auréola de metamorfismo de contato dos diques.

A mineralogia dos minérios de talco é simples. Nas jazidas tipo talco xisto os minérios são compostos essencialmente por talco, calcita, quartzo, dolomita, e quantidades subordinadas de clorita, serpentina e tremolita. A talcificação se deu pela reação da dolomita com soluções aquosas com sílica (3dolomita +4 sílica $_{a q}=$ talco + 
$3 \mathrm{Ca}^{2+}{ }_{\text {aq }}+6 \mathrm{CO}_{2}$ ). Além do talco, foram gerados calcita e quartzo, este último devido à entrada de sílica após o consumo total de dolomita ou após o pico térmico, fora do campo de estabilidade do talco. Estima-se que a formação dos talco xistos tenha ocorrido em temperatura próxima a $400^{\circ} \mathrm{C}$ e com baixa $\mathrm{X}_{\mathrm{CO} 2}$, dada a percolação de grandes volumes de água nos planos de cisalhamento, com relação fluido:rocha superior a 500:1 em volume, o que diluiu até a virtual eliminação total $\mathrm{o} \mathrm{CO}_{2}$ liberado pela talcificação.

Os minérios do tipo talco maciço fino apresentam mineralogia mais simples, com talco, calcita, quartzo e dolomita. As relações de campo sugerem que o minério de talco maciço possa ter se formado na periferia das zonas de cisalhamento onde se formou o minério tipo talco xisto. As observações sugerem que estes mesmos fluidos possam ter causado a talcificação incipiente ao longo das descontinuidades estruturais dos metadolomitos não diretamente afetados pela zona de cisalhamento, e serem responsáveis pela formação dos bolsões de talco fino, maciço, pulverulento, porém com indicações de temperaturas mais baixas.

No metamorfismo de contato próximo ao granito, as temperaturas foram mais elevadas e a disponibilidade de $\mathrm{CO}_{2}$ no fluido foi maior, pois não havia grande volume de fluidos aquosos para a sua diluição. Com isto, as paragêneses evoluíram no sentido da formação de tremolita ao invés de talco, este se formando apenas em quantidades subordinadas por retrometamorfismo.

A maioria dos minerais presentes na talcificação apresenta composição próxima à composição pura dos membros extremos das respectivas soluções sólidas, fornecendo portanto poucas informações sobre as condições de metamorfismo. Uma exceção importante é a composição de carbonatos, em particular a fração molar de $\mathrm{Mg}\left(\mathrm{X}_{\mathrm{Mg}}\right)$ na calcita coexistente com dolomita, pelo seu potencial como geotermômetro. Os valores de $\mathrm{X}_{\mathrm{Mg}}$ na calcita em talco xisto indicam temperaturas entre $220^{\circ}$ e $400^{\circ} \mathrm{C}$, e em minérios de talco maciço fino entre $230^{\circ}$ e $340^{\circ} \mathrm{C}$. Na auréola de contato com o Complexo Granítico Cunhaporanga as temperaturas estimadas estão entre $250^{\circ}$ e $503^{\circ} \mathrm{C}$. Apesar de sua sensibilidade como geotermômetro, os valores de $\mathrm{X}_{\mathrm{Mg}}$ apresentam grande dispersão intra- e intergrão, causada por sucessivas recristalizações parciais pela interação com soluções de menor temperatura.

Os isótopos estáveis de carbono e oxigênio confirmam a baixa concentração de $\mathrm{CO}_{2}$ no fluido mineralizante. A partir da composição do metadolomito original os 
processos superimpostos de brechação e talcificação causaram uma diminuição dos valores de $\delta^{18} \mathrm{O}$, praticamente sem afetar os valores de $\delta^{13} \mathrm{C}$. A análise do fracionamento isotópico em pares coexistentes de dolomita e calcita indicou o predomínio de desequilíbrio isotópico, de modo análogo ao observado em relação ao $\mathrm{X}_{\mathrm{Mg}}$ em calcita. Os dados isotópicos no contexto do metamorfismo termal, tanto no contato com granito como com os diques de diabásio, indicam forte desequilíbrio entre dolomita e calcita coexistentes.

Os dados preliminares de inclusões fluidas revelam o potencial deste método para a análise da interação fluido-rocha em sistemas de talcificação. Conforme já indicado pelas paragêneses metamórficas, os fluidos aprisionados nas inclusões têm baixa ou nula fração molar de $\mathrm{CO}_{2}$, indicando que a fase gasosa gerada pela descarbonatação dos metadolomitos foi eficientemente diluída em soluções aquosas que continuaram a percolar o sistema de canais por período relativamente longo, enquanto houve gradiente geotérmico suficiente para tal. Inclusões fluidas em minerais da auréola de contato com o granito apresentam elevada fração de $\mathrm{CO}_{2}$, indicando uma condição de menor percolação de fluidos externos, onde a composição dos fluidos metamórficos foi controlada pela reação de descabonatação da dolomita para formação dos silicatos magnesianos de alta temperatura (forsterita, diopsídio, tremolita).

As soluções mineralizantes da talcificação percolaram o metadolomito através das zonas de cisalhamento, planos de fraturas e descontinuidades estruturais, devido ao gradiente geotérmico elevado, provocado pela presença dos dois batólitos graníticos que delimitam o Grupo Itaiacoca, ambos colocados no Ciclo Brasiliano, ao final do qual se instalaram as zonas de cisalhamento transcorrentes às quais se associam as principais jazidas de talco da região. O fluxo das soluções hidrotermais pode ter sido controlado também por bombeamento tectônico nas zonas de cisalhamento e suas ramificações.

O gradiente geotérmico induzido pelo batólitos graníticos foi o fator chave para a geração de talco no Grupo Itaiacoca. Uma indicação disto é a inexistência de talco na Formação Capiru, situada próxima ao Grupo Itaiacoca e de idade semelhante, com composição igualmente dolomítica, e igualmente afetada por zonas de cisalhamento e por diques de diabásio. A principal diferença entre estas duas unidades metadolomíticas é o fluxo térmico das rochas vizinhas e subjascentes: o Grupo Itaiacoca situa-se em porção aquecida da uma crosta, devido aos batólitos graníticos neoproterozóicos, enquanto que a Formação Capiru se assenta por falhas de cavalgamento sobre 
migmatitos arqueanos do Complexo Atuba, que representaram um escudo estável com gradiente geotérmico mais baixo no Neoproterozóico. O calor liberado pelas rochas graníticas assegurou a circulação suficiente de fluidos para a transformação dos metadolomitos de Itaiacoca em talco. 


\section{Referências bibliográficas}

Almeida, F.F.M., 1956. Novas ocorrências de fósseis no pré-cambriano brasileiro. An. Acad. Bras. Ciências, 28:44-45.

Almeida, F.F.M., 1983. Relaçōes tectônicas das rochas alcalinas mesozóicas da região meridional da plataforma sul-americana. Rev. Bras. Geociências, 13(3):139-158.

Almeida, F.F.M., Amaral, G., Cordani, U.G., Kawashita, K., 1973. The precambrian evolution of the south american cratonic margin south of Amazon River, in: Nairn, E.M., Stehli, F.G. ( Eds.), The Ocean Basins and Margins. vol. 1. Plenum, New York, pp. 411-446.

Anderson, D.L., Mogk, D.W., Childs, J.F. 1990. Petrogenesis and timing of talc formation in the Ruby Range, Southwestern Montana. Econ. Geol., 85: 585-600

Andrade, F.R.D., Szabó, G.A.J., Guimarães, G.B., 2005. A talcificação de metadolomitos do Grupo Itaiacoca: dados preliminares de isótopos estáveis $(\mathrm{C}, \mathrm{O})$ e geotermometria. Anais do I Simp. Bras. Metalogenia (CD-ROM).

Anovitz, L.M., Essene, E.J., 1987. Phase equilibria in the system $\mathrm{CaCO}_{3}-\mathrm{MgCO}_{3}-\mathrm{FeCO}_{3}$. J. Petrol., 28:389-414

Antoniassi, J.L., 2003. Quantificação mineral de misturas carbonato talco anfibólio por difratometria de raios X. Iniciação Científica. (Graduando em Geologia) - Universidade de São Paulo, Conselho Nacional de Desenvolvimento Científico e Tecnológico. Orientador: Fabio Ramos Dias de Andrade.

Araújo, J.C.K., Godoy, L.C., Souza, P.E. de C., Dias, R.B., 1987. Caracterização, prospecção e avaliação de jazidas de talco da Faixa Itaiacoca no Estado do Paraná. In: Simpósio Sul-Brasileiro de Geologia, 3., 1987. Curitiba. Anais... Curitiba: SBG, 1987, 2:633-643.

Archer, D.G., 1992. Thermodynamic properties of the $\mathrm{NaCl}-\mathrm{H}_{2} \mathrm{O}$ system:II. Thermodynamic properties of $\mathrm{NaCl}(\mathrm{aq}), \mathrm{NaCl} \cdot 2 \mathrm{H}_{2} \mathrm{O}(\mathrm{cr})$, and phase equilibria. Journal of Physical and Chemical Reference Data, 28:1-17.

Azmy, K., Veizer, J., Misi, A., de Oliveira, T.F., Sanches, A.L., Dardenne, M.A., 2001. Dolomitization and isotope stratigraphy of the Vazante Formation, São Francisco Basin, Brazil. Precambrian Res., 112(3-4):303-329.

Bakker, R.J., 2003. Package FLUIDS 1. Computer programs for analysis of fluid inclusion data and for modeling bulk fluid properties. Chemical Geology 194: 3-23.

Barbosa, O., 1943. Pesquisa da jazida de talco de Moura, Distrito de Itaiacoca, Município de Ponta Grossa, Estado do Paraná. (Decreto nr. 13.330, de 13/09/43).

Baumgartner, L.P., Valley, J.W. 2001. Stable isotope transport and contact metamorphic fluid flow. In: J.W. Valley, D.R. Cole (editors) Stable isotopes geochemistry. Mineral. Soc. Am., Reviews in Mineralogy, 43:415-467.

Bigarella, J.J., 1947. Ocorrência de dolomito no município de Cêrro Azul, Paraná. Mineração e Metalurgia, XI(66):323-326. 
Bigarella, J.J., Salamuni, R., 1956. Estudos preliminares da Série Açunguí. V. Estruturas organógenas nos dolomitos da Formação Capiru (Estado do Paraná), Dusenia, Curitiba, 7(6):317-323.

Blount, A.M., Vassiliou, A.H., 1980. The mineralogy and origin of the talc deposits near Winterboro, Alabama. Econ. Geol., 75: 107-116.

Bodnar, R.J., Vityk, M.O., 1994. Interpretation of the microthermometric data for $\mathrm{H}_{2} \mathrm{O}-\mathrm{NaCl}$ fluid inclusions in minerals: Methods and Applications. Short Course IMA, pp. 117-130.

Boulvais, P., de Parseval, P., D’Hulst, A., Paris, P., 2006. Carbonate alteration associated with talcchlorite mineralization in the eastern Pyrenees, with emphasis on the St. Barthelemy Massif. Mineral. Petrol., 88:499-526

Bowen, N.L., 1940. Progressive metamorphism of siliceous limestone and dolomite. J. Geology, 48:225274.

Brady, J.B., Cheney, J.T., Rhodes, A.L., Vasquez, A., Green, C., Duvall, M., Kogut, A., Kaufmann, L., 1998. Isotope geochemistry of proterozoic talc occurrences in Archean marbles of the ruby Mts., southwest Montana, USA. Geol. Mat. Res., 1:1:41.

Campanha, G.A., Bistrichi, C.A., Almeida, M.A., 1987. Considerações sobre a organização e evoluçāo tectônica da Faixa de Dobramentos Apiaí. in: Atas III Simp. Sul Bras. Geol., Curitiba, 2:725-742.

Campanha, G.A., Sadowski, G.R., 1999. Tectonics of the southern portion of the Ribeira Belt (Apiaí Domain). Precambr. Res., 98:31-51.

Cook, S.J., Bowman, J.R., 1994. Contact metamorphism surrounding the Alta stock: thermal constraints and evidence of advective heat transport from calcite + dolomite thermometry. Am. Mineralogist, 79:513-525.

CPRM (Companhia de Pesquisa de Recursos Minerais). 1977. Projeto Leste do Paraná. Folha Piraí do Sul, 1:100.000. Relatório final. São Paulo, DNPM-CPRM-BADEP, vol. I, 119 p.

Davis, D.W., Lowenstein, T.K., Spencer, R.J., 1990. Melting behaviour of fluid inclusion in Iaboratorygrown halite crystals in the systems $\mathrm{NaCl}-\mathrm{H}_{2} \mathrm{O}, \mathrm{NaCl}-\mathrm{KCl}-\mathrm{H}_{2} \mathrm{O}, \mathrm{NaCl}-\mathrm{MgCl}_{2}-\mathrm{H}_{2} \mathrm{O}$ and $\mathrm{NaCl}-$ $\mathrm{CaCl}_{2}-\mathrm{H}_{2} \mathrm{O}$. Geochimica et Cosmochimica Acta, 54: 591 601.

DNPM (Departamento Nacional de Produção Mineral), 2006a. Anuário Mineral Brasileiro 2006. www.dnpm.gov.br (acessado em 08 de janeiro de 2008)

DNPM (Departamento Nacional de Produção Mineral), 2006b. Sumário Mineral Brasileiro 2006. www.dnpm.gov.br (acessado em 09 de abril de 2007)

DNPM (Departamento Nacional de Produção Mineral), 2007. Sumário Mineral Brasileiro 2007. www.dnpm,gov.br (acessado em 08 de janeiro de 2008)

DNPM-MINEROPAR (Departamento Nacional de Produção Mineral - Minerais do Paraná S.A.). 1999. Avaliação Metalogenética do Distrito Mineiro do Talco no Estado do Paraná. Relatório Final (texto e anexos). Curitiba. (Autores: Ribas, S.M.; David, C.A.S.; Brandão, W.; Valaski, Z. de F.)

Eggert, R.G., Kerrick, D.M., 1981. Metamorphic equilibria in the siliceous dolomite system: $6 \mathrm{kbar}$ experimental data and geologic implications. Geochim. Cosmochim. Acta, 45:1039-1049.

El-Sharkawy, M.F., 2000. Talc mineralization of ultramafic affinity in the Eastern Desert of Egypt. Mineralium Deposita, 35:346-363. 
Evans, B.W.; Guggenheim, S., 1988. Talc, pyrophyllite and related minerals. In: Bailey, S.W. Hydrous phyllosilicates (exclusive of micas). Reviews in Mineralogy, Mineralogical Society of America, 19:225-294.

Fassbinder, E., 1996. A Unidade Água Clara no contexto do Grupo Açunguí: um modelo transpressivo de colisão oblíqua no Neoproterozóico paranaense. Tese (Doutorado) - Instituto de Geociências, Universidade de São Paulo, São Paulo.

Fein, J.B., Walther, J.V., 1987. Calcite solubility in supercritical $\mathrm{CO}_{2}-\mathrm{H}_{2} \mathrm{O}$ fluids. Geochim. Cosmochim. Acta, 51:1665-1673.

Fiori, A.P., 1990. Tectônica e estratigrafia do Grupo Açungui a norte de Curitiba. São Paulo. Tese de Livre-docência, Inst. Geociências, USP, 246 p.

Fiori, A.P., 1992. Tectônica e estratigrafia do Grupo Açunguí, PR. Boletim IG-USP, Série Científica, 25:55-74

Fournier, R.O., 1985. The behaviour of silica in hydrothermal solutions. in: Geology and geochemistry of epithermal systems (eds. B,R. Berger e P.M. Bethke), pp. 45-61. Soc. Econ. Geol.

Fournier, R.O., Potter, R.W., 1982. An equation correlating the solubility of quartz in water from $25^{\circ}$ to $900^{\circ} \mathrm{C}$ at pressures up to 10,000 bars. Geochim. Cosmochim. Acta, 46:1969-1973

Fuck, R.A., 1967. Geologia da Folha de Abapã. Boletim da Universidade Federal do Paraná, v. 25, p. 33.

Goldstein, R.H., 2001. Fluid inclusions in sedimentary and diagenetic systems. Lithos, 55:159-193.

Goldstein, R.H., Reynolds, T.J., 1994. Systematics of fluid inclusions in diagenetic minerals. SEPM (Society for Sedimentary Geology) Short Course 31, Tulsa, Oklahoma, 199p.

Gondim, A.C., Loyola, L.C., 2002. Ponta Grossa and Castro zones in Paraná talc district, Brazil: ore properties and mineral industry. IGCP 443 - (Magnesite and talc) Newsletter $\mathrm{N}^{\circ} 2$ - Boletim Paranaense de Geociências, 50:9-14.

Gordon, T.M., Greenwood, H.J., 1970. The reaction: dolomite + quartz + water $=$ talc + calcite + carbon dioxide. Am. J. Science, 268:225-242.

Greenwood, H.J., 1975. Buffering of pore fluids by metamorphic reactions. Am. J. Science, 275:573-593.

Gruner, J.W. 1934. The crystal structures of talc and pyrophyllite. Zeitschrift fuer Kristallographie, Kristallgeometrie, Kristallphysik, Kristallchemie, 88:412-419 (26741-ICSD)

Gualtieri, A, inédito, A guided training exercise of quantitative phase analysis using EXPGUI.

Guimarães, G.B., 2000. As rochas granitóides do Complexo Granítico Cunhaporanga: aspectos geológicos, geofisicos, geoquímicos e mineralógicos. Tese (Doutorado) - Instituto de Geociências, Universidade de São Paulo, São Paulo.

Guimarães, G.B., Ulbrich, H.H.G.J., Janasi, V.A., 2000. Geothermobarometry of granitoid rocks: a case study from the Neoproterozoic Cunhaporanga Granitic Complex, southern Brazil. In: International Geological Congress, 31., 2000. Rio de Janeiro. Anais..., Rio de Janeiro, 2000.

Hasui, Y., Carneiro, C.D.R., Coimbra, A.M., 1975. The Ribeira folded belt. Rev. Bras. Geoc., 5(4):257266.

Hecht, L., Freiberger, R., Gilg, H.A., Grundmann, G., Kostitsyn, Y.A., 1999. Rare earth element and isotope $(\mathrm{C}, \mathrm{O}, \mathrm{Sr})$ characteristics of hydrothermal carbonates: genetic implications for dolomitehosted talc mineralization at Göpfersgrün (Fichtelberg, Germany). Chem. Geol., 155: 115-130. 
Holness, M.B., 1992. Metamorphism and fluid infiltration of the calc-silicate aureole of the Beinn an Dubhaich granite, Skye. J. Petrology, 33:1261-1293.

Holness, M.B., 1997. Fluid flow paths and mechanisms of fluid infiltration in carbonates during contact metamorphism: the Beinn an Dubhaich aureole, Skye. J. Metam. Geology, 15:59-70.

Holness, M.B., Fallick, A.E., 1997. Palaeohydrology of the calcsilicate aureole of the Beinn an Dubhaich granite, Skye, Scotland: a stable isotopic study. J. Metam. Geology, 15:71-83.

Holness, M.B., Graham, C.M., 1991. Equilibrium dihedral angles in the system $\mathrm{H}_{2} \mathrm{O}-\mathrm{CO}_{2}-\mathrm{NaCl}-$ calcite, and implications for fluid flow during metamorphism. Contrib. Mineral. Petrology, 108:368-383.

Hutchison, C.S., 1974. Laboratory Handbook of Petrographic Techniques. New York: Wiley Interscience, $527 \mathrm{p}$.

IPT (Instituto de Pesquisas Tecnológicas do Estado de São Paulo). 1985 Geologia das Folhas Barra do Chapéu (SG-22-X-B-I-4) e Araçaíba (SG-22-X-B-II-3), Estados de São Paulo e Paraná, São Paulo (Relatório 22150).

Jurinski, J.B., Rimstid,, J.D., 2001. Biodurability of talc. American Mineralogist, 86:392-399.

Knight, C.L., Bodnar, R.J., 1989. Synthetic fluid inclusions: IX. Critical PVTX properties of $\mathrm{NaCl}-\mathrm{H}_{2} \mathrm{O}$ solutions. Geochimica et Cosmochimica Acta, 53: 3-8.

Krauskopf, K.B., Bird, D.K., 1995. Introduction to geochemistry, 3rd Edition, McGraw Hill, New York, $647 \mathrm{p}$.

Larson, A.J., Von Dreele, R.B. 2000. General Structure Analysis System (GSAS). Software disponível em www.ncnr.nist.gov/xtal/software/gsas.html (acessado em 13.02.2007)

Letargo, C.M., Lamb, W.M., Park, J.S., 1995. Comparison of calcite + dolomite thermometry and carbonate + silica equilibria: constraints on the conditions of metamorphism of the Llano uplift, central Texas, U.S.A. Am. Mineral., 80:131-143.

Lima, R.E., 1992. Evolução geológica dos depósitos de talco da regiăo de Itaiacoca e Abapã - Paraná. In: Congresso Brasileiro de Geologia, 37. São Paulo. Anais... São Paulo:SBG, 1992. v. 1, p. 265266.

Lima, R.E., 1993a. Evolução geológica e controles dos depósitos de talco da região de Haiacoca, Abapã, $P R$. Diss. Mestrado, inédita, UnB.

Lima, R.E., 1993b. Geologia da Faixa Itaiacoca / PR: estratigrafia, litologias, depósitos de talco e intrusivas associadas. In: Simpósio Sul Brasileiro de Geologia, 5., 1993. Curitiba. Anais... Curitiba:SBG, v. 2, p. 30-35.

Lima, R.E., 1997. Geologia das jazidas de talco do Paraná. In: Encontro de Mineradores e Consumidores, 5., Anais..., Assoc. Bras. de Cerâmica / SENAI-PR 1997, p. 08-11.

Lima, R.E., Dardenne M.A., 1987. Geologia e controle da Mina Grande da Costalco - Itaiacoca (PR). In: Simpósio Sul Brasileiro de Geologia, 3. Curitiba, Anais... Curitiba:SBG, 1987. v. 2, p. 623-632.

Luce, R.W., Cygan, G.L., Hemley, J.J., D'Angelo, W.M., 1985. Some mineral stability relations in the system CaO-MgO-SiO ${ }_{2}-\mathrm{H}_{2} \mathrm{O}-\mathrm{HCl}$. Geochim. Cosmochim. Acta, 49:525-538. 
Marini, O., Trein, E., Fuck, R.A., 1967. O Grupo Açunguí no Estado do Paraná. in: Bigarella, J.J., Salamuni, R., Pinto, V.M. (eds.) Geologia do Pré-Devoniano e instrusivas subsequentes da porção oriental do Estado do Paraná. Boletim Paranaense de Geociências, 23-25:43-103.

McCusker, L.B., Von Dreele, R.B., Cox, D.E., Louer, D., Scardi, P., 1999. Rietveld refinement guidelines. J. Appl. Crystal., 32:36-50.

McDonald, J.C., McDonald, A.D., 1997. Chrysotile, tremolite and carcinogenicity. Ann. Occup. Hygiene, 41(6):699-705.

Moine, B., Fortune, J.P., Moreau, P., Viguier, F., 1989. Comparative mineralogy, geochemistry and conditions of formation of two metasomatic talc and chlorite deposits: Trimmouns (Pyrenees, France) and Rabenwald (Eastern alps, Austria). Economic Geol, 84:1398-1416.

Moore, D.E., Lockner, D.A., no prelo. Talc friction in the temperature range $25^{\circ}-400^{\circ} \mathrm{C}$ : relevance for fault-zone weakening. Tectonophysics.

Niklinski, J., Niklinska, W., Chyczewska, E., Laudanksi, J., Naumnik, W., Chyczewski, L., Pluygers, E., 2004. The epidemiology of asbestos-related diseases. Lung cancer, 1:7-15.

O'Neil, J.R., Clayton, R.N., Mayeda, T.K.., 1969. Oxygen isotope fractionation in divalent metal carbonates. J. Chem. Phys., 51:5547-5558.

Ohmoto, H., Rye, R.O. 1979. Isotopes of sulfur and carbon. in: H.L. Barnes (ed.) Geochemistry of hydrothermal ore deposits, 2nd ed., John Wiley \& Sons, New York, pp. 509-567.

Paiva-Santos, C., 2006. Curso: Método de Rietveld, IPEN, CD-ROM.

Perdikatsis, B., Burzlaff, $\mathrm{H} .$, 1981. Strukturverfeinerung an Talk $\mathrm{Mg}_{3}\left((\mathrm{OH})_{2} \mathrm{Si}_{4} \mathrm{O}_{10}\right)$. Zeitschrift fuer Kristallographie, 156:177-186. (100682-ICSD)

Piccirillo, E.M., Melfi, A.J., 1998. The Mesozoic flood volcanism of the Parana Basin. São Paulo, IAGUSP.

Picolo, C.E.B., 2002. Estudo de beneficiamento por flotação de minério de talco em metadolomito da Faixa Itaiacoca, PR. Trabalho de Conclusão de Curso. (Graduação em Geologia) - Universidade de São Paulo. Orientador: Fabio Ramos Dias de Andrade

Pili, E., Poitrasson, F., Gratier, J.P. 2002. Carbon-oxygen and trace element constraints on how fluids percolate faulted limestones from the San Andreas Fault system: partitioning of fluid sources and pathways. Chem. Geol, 190:231-250.

Prazeres Filho, H.J., 2000. Litoquímica, geocronologia $\left(U_{\sim} P b\right)$ e geologia isotópica dos Complexos Graníticos Cunhaporanga e Três Córregos, Estado do Paraná. Dissertação de Mestrado, IGcUSP, $180 \mathrm{p}$.

Prazeres Filho, H.J., Harara, O.M., Basei, M.A.S., Passarelli, C.R., Siga Jr., O. 2003. Litoquímica, geocronologia U-Pb e geologia isotópica (Sr-Nd-Pb) das rochas graníticas dos Batólitos Cunhaporanga e Três Córregos na porção sul do Cinturão Ribeira, Estado do Paraná. GeologiaUSP, Série Cientifica, 03:51-70.

Prazeres Filho, H.J., Guimarães, G.B., Basei, M.A.S, Siga Jr., O., Reis Neto, J.M., Campanha, G., Sallun Filho, 1998. Mapa geológico 1:50.000 da porção centro-sul da Faixa Itaiacoca - PR. In; Congr. Bras. Geol., 40, Belo Horizonte, 1998, Anais..., Belo Horizonte, SBG.

Prochaska, W., 1989. Geochemistry and genesis of Austrian talc deposits. Appl. Geochem., 4: 511-525. 
Prochaska, W., Mogessie, A., Raith, J.G., 1992. Formation of the talc deposit of Kibanda (Rwanda) and its relation to the regional metamorphic evolution. J. African Earth Sci., 14: 499-509

Puhan, D. 1995. Metamorphic evolution of the assemblage tremolite + talc + calcite + dolomite + quartz within a sample of siliceous dolomite from the Southern Damara Orogen (Namibia). Contrib. Mineral. Petrol., 120:180-185.

Rapp, G. 2002. Archaeomineralogy. Springer Verlag, Berlin, 326 p.

Rayner, J.H., Brown, G. 1973. The crystal structure of talc, Clays and Clay Minerals. 21:103-114. (21017-ICSD)

Reinhold, C., 1998. Multiple episodes of dolomitization and dolomite recrystallization during shallow burial in Upper Jurassic shelf carbonates: eastern Swabian Alb, southern Germany. Sedimentary Geol., 121:71-95.

Reis Neto, J.M., Rebelo, A.M.A., Basei, M.A.S., 2004. Jura-Cretaceous hydrothermalism as genesis of mineralization in dolomitic marbles of Itaiacoca Belt, Brazil. In: International Congress on Applied Mineralogy, 8. Águas de Lindóia, Proceedings... Águas de Lindóia:IMA, 2004, v. 1, p. 733-736.

Reis Neto, J.M., 1994. Faixa ltaiacoca: registro de uma colisão entre dois blocos continentais no Neoproterozóico. Tese de Doutoramento (inédita). São Paulo, Instituto de Geociências-USP, 255 p.

Renne, P.R., Deckart, K., Ernesto, M., Féraud, G., Piccirillo, E.M., 1996. Age of the Ponta Grossa dike swarm (Brazil), and implications to Paranánext term flood volcanism. Earth Planetary Sci. Letters, 144(1-2):199-211.

Rice J.M., 1977. Progressive metamorphism of impure dolomitic limestone in the Marysville aureole, Montana. Am. J. Science, 277:1-24.

Richards, R., 2003. What effect do mineral particles have in the lung? Mineralogical Magazine, 67(2):129-139

Rietveld, H., 1969. A profile refinement for nuclear and agnetic structures. J. Appl. Cryst., 2:65-71.

Rimstidt, J.D., 1997. Quartz solubility at low temperatures. Geochim. Cosmochim. Acta, 61(13):25532558.

Roedder, E., 1984. Fluid Inclusions. In: Ribbe, P.H. (Ed.), Reviews in Mineralogy, vol 12. Mineralogical Society of of America. 646pp.

Sallun Filho, W., Campanha, G.A.C., Fairchild, T.R., 2005. Aapectos deformacionais em estromatólitos do Grupo Itaiacoca, a sul de Itapeva (SP). Rev. Bras. Geociências, 35(3):333-340

Sallun Filho, W., Fairchild, T.R., 2004. Estromatólitos do Grupo Itaiacoca ao sul de Itapeva, Estado de São Paulo, Brasil. Rev. Bras. Paleontol., 7(3):359-370.

Santos, R.V., Alvarenga, C.J.S., Dardenne, M.A., Sial, A.N., Ferreira, V.P., 2000. Carbon and oxygen isotope profiles across Meso-Neoproterozoic limestones from central Brazil: Bambuí and Paranoá groups. Precambr. Res., 104:107-122.

Schandl, E.S., Sharara, N.A., Gorton, M.P., 1999. The origin of the Atshan talc deposit in the Hamata area, eastern Desert, Egypt: a geochemical and mineralogical study. Can. Mineral., 37: 12111227 
Schärer, U., de Parseval., P., Polvé, M., Blanquat, M.S., 1999. Formation of the Trimouns talc-chlorite deposit (Pyrenees) from persistent hydrothermal activity between 112 and $97 \mathrm{Ma}$. Terra Nova, 11:30-37.

Scliar, C., 1998. Amianto: mineral mágico ou maldito? CDI, Belo Horizonte, $152 \mathrm{p}$.

Selikoff, I. J., Lee, D. H. K., 1978. Asbestos and disease. American Press, New York, 549 p.

Sheppard, S.M.F., Schwarcz, H.P. 1970. Fractionation between carbon and oxygen isotopes and magnesium between coexisting metamorphic calcite and dolomite. Contrib. Mineral. Petrol., 26:161-198.

Shin, D., Lee, I., 2002. Carbonate-hosted talc deposits in the contact aureole of an igneous intrusion (Hwanggangri mineralized zone, South Korea): geochemistry, phase relationships, and stable isotope studies. Ore Geology Reviews, 22:17-39.

Siga Jr.,O., Basei, M.A.S., Sato, K., Prazeres Filho, H.J., Cury, L.F., Weber, W., Passarelli, C.R., Harara, O.M., Reis Neto, J.M., 2003. U.Pb (zircon) ages of metavolcanic rocks from the Itaiacoca Group: tectonic implications. Geologia USP - Série Cientifica, 03: 39-49.

Skinner, H. C. W., Ross, M., Frondel, C., 1988. Asbestos and other fibrous minerals. Oxford Press, New York, $204 \mathrm{p}$.

Skippen, G., 1974. An experimental model for low pressure metamorphism of siliceous dolomitic marble. Am. Jour. Science, 274:487-509.

Skippen, G., Trommsdorff, V., 1986. The influence of $\mathrm{NaCl}$ and $\mathrm{KCl}$ on phase relations in metamorphosed carbonate rocks. Am. Jour. Science, 286:81-104.

Slaughter, J., Kerrick, D.M., Wall V.J., 1975. Experimental and thermodynamic study of equilibria in the system $\mathrm{CaO}-\mathrm{MgO}-\mathrm{SiO}_{2}-\mathrm{H}_{2} \mathrm{O}-\mathrm{CO}_{2}$. Am. Jour. Science, 275:143-162.

Soares, P.C. 1987. Sequiências tecto-sedimentares e tectônica deformadora no centro-oeste do Escudo Paranaense. In: Simpósio Sul Brasileiro de Geologia, 3., 1987. Curitiba, Anais... Curitiba:SBG, 1987. v. 2, p. 743-771.

Soares P.C., Stevanatto R., Camargo C.R. 1987. Geologia do noroeste da Faixa Itaiacoca - Paraná. In: Simpósio Sul Brasileiro de Geologia, 3., 1987. Curitiba, Anais... Curitiba:SBG, 1987. v. 1, p. 245-262.

Sobanski A., Giusti D.A., Chodur N.L., 1984. As jazidas de talco de Abapã, município de Castro (PR). In: In: Congresso Brasileiro de Geologia, 33., 1984. Rio de Janeiro. Anais... Rio de Janeiro:SBG. v. 8, p. 3799-3808.

Souza, A., 1990. Mapa Geológico na escala 1:50.000 e esboço da evolução tectônica e sedimentar do Grupo ltaiacoca, nas folhas Barra do Chapéu e Ouro Verde - SP/PR. Dissertação de Mestrado (inédita). São Paulo, Instituto de Geociências, USP, 200 p.

Spear, F., 1993. Metamorphic phase equilibria and pressure-temperature-time paths. Mineral. Soc. Am., $799 \mathrm{p}$.

Szabó, G.A.J., Andrade, F.R.D., Guimarães, G.B. Moya, F.A., Carvalho, F.M.S., 2004. Genesis of talc deposits and the metamorphic history of the Itaiacoca Group metadolomites, southern Brazil. in: Proc. 8th Int. Congr. Appl. Mineral. - ICAM2004, Águas de Lindóia, SP, vol. 1, pp. 759-761. 
Szabó, G.A.J., Andrade, F.R.D., Guimarães, G.B., Carvalho, F.M.S., Moya, F.A. 2006. As jazidas de talco no contexto da história metamórfica dos metadolomitos do Grupo Itaiacoca, PR. GeologiaUSP, Série Científica.

Szabó, G.A.J., Madureira Filho, J.B., Carvalho, F.M.S., Andrade, F.R.D., Guimarães, G.B., 2000. Amphibole asbestos contamination in mineral raw materials: the example of some Brazilian talc deposits. In: Global Asbestos Conference, Osasco, São Paulo, Brasil. Global Asbestos Conference, Anais, 2000.

Taylor, H.P., Jr. 1979. Oxygen and hydrogen isotope relationships in hydrothermal mineral deposits. in: H.L. Barnes (ed.) Geochemistry of hydrothermal ore deposits, 2nd ed., John Wiley \& Sons, New York, pp.236-276.

Tilley, C.E., 1948. Earlier stages in the metamorphism of siliceous dolomite. Mineral. Magazine, 85:213216.

Toby, B.H., 2001. Editor Graphic User Interface for GSAS (EXPGUI). Software disponível em www.ncnr.nist.gov/xtal/software/gsas.html (acessado em 13.02.2007)

Tornos, F., Spiro B.F. 2000. The geology and isotope geochemistry of the talc deposits of Puebla de Lillo (Cantabrian Zone, Northern Spain). Economic Geology, 95:1277-1296.

Turner, S., Regelous, M., Kelley, S., Hawkesworth, C.J., Mantovani, M.A.M., 1994. Magmatism and continental break-up in the South Atlantic: high precision 40Ar-39Ar geochronology. Earth Planet. Sci. Lett. 121, 333-348.

USGS (United States Geological Survey), 2007. Mineral Commodity Summary 2007. www.usgs.gov (acessado em 10 de janeiro de 2008)

Van Gosen, B.S., Lowers, H.A., Sutley, S.J., Gent, C.A., 2004, Using the geologic setting of talc deposits as an indicator of amphibole asbestos content. Environmental Geology, 45(7):920-939.

Vasconcelos, C., McKenzie, J.A., 1997. Microbial mediation of modern dolomite precipitation and diagenesis under anoxic conditions (Lagoa Vermelha, Rio de Janeiro, Brazil). J. Sedim. Res., 67(3):378-390.

Vasconcelos, C., McKenzie, J.A., Bernasconi, S., Grujic, D., Tien, A.J., 1995. Microbial mediation as a possible mechanism for natural dolomite formation at low temperature. Nature, 337:220-222.

Verma, M.H., 2000. Revised quartz solubility temperature dependence equation along the water-vapour saturation curve. in Proc. World Getherm. Congr 2000, Japão, p. 1927-1932.

Virta, R. L., 1998. Mineral yearbook: Asbestos. USGS, www.usgs.gov

Virta, R.L., 2004. Talc and pyrophyllite. United States Geological Survey Minerals Yearbook 2004. www.usgs.gov

Walther, J.V., Orville, P.M., 1983. The extraction-quench technique for determination of the thermodynamic properties of solute complexes: application to quartz solubility in fluid mixtures. Am. Mineral., 68:731-741.

Wang, H.M., Henderson, G.S., Brenan, J.M., 2004. Measuring quartz solubility by in situ weight-loss determination using a hydrothermal diamond cell. Geochim. Cosmochim. Acta, 68(24):51975204. 
Warren, J., 2000. Dolomite: occurrence, evolution and economically important associations. Earth Science Rev., 52:1-81.

Weber, W., Siga Jr., O, Sato, K., Reis Neto, J.M., Basei, M.A.S., Nutman, A.P., 2004. A Formação Água Clara na região de Araçaiba - SP: registro U-Pb de uma bacia mesoproterozóica. Geologia USP: Série Cientifica, v. 4, p. $101-110$.

Zhang, Y, Frantz, J.D., 1987. Determination of the homogenization temperatures and densities of supercritical fluids in the system $\mathrm{NaCl}-\mathrm{KCl}-\mathrm{CaCl}_{2}-\mathrm{H}_{2} \mathrm{O}$ using synthetic fluid inclusions. Chemical Geology, 64: 335-350. 
Anexos 
Anexo Tabela A-1. Análises químicas de dolomita do Grupo Itaiacoca (proporção catiônica recalculada para 6 átomos de oxigênio por fórmula unitária).

\begin{tabular}{|c|c|c|c|c|c|c|c|c|c|c|c|}
\hline \multirow{3}{*}{$\begin{array}{l}\text { litotipo } \\
\text { amostra } \\
\text { análise nr, }\end{array}$} & \multicolumn{7}{|c|}{ (a) talco xisto } & \multicolumn{4}{|c|}{ (b) talco maciço fino } \\
\hline & $02 \mathrm{ABl}$ & $02 \mathrm{ABI}$ & $02 \mathrm{CA}$ & $22 \mathrm{~L}$ & $22 \mathrm{~L}$ & $55 \mathrm{C}$ & $55 \mathrm{C}$ & $38 \mathrm{E}$ & $38 \mathrm{E}$ & $42 \mathrm{~A}$ & $42 \mathrm{~A}$ \\
\hline & 19 & 303 & 343 & 199 & 426 & 369 & 368 & 407 & 405 & 325 & 326 \\
\hline $\mathrm{SiO} 2$ & 0,72 & 0 & 0 & 0,01 & 0 & 0 & 0 & 0,64 & 0.1 & 0 & 0 \\
\hline SrO & 0,03 & 0 & 0 & 0,01 & 0 & 0 & 0 & 0 & 0 & 0 & 0 \\
\hline $\mathrm{FeO}$ & 0,06 & 0 & 0,03 & 0,09 & 0,15 & 0,09 & 0,04 & 0,21 & 0,14 & 0,05 & 0,12 \\
\hline $\mathrm{MnO}$ & 0,01 & 0 & 0 & 0,01 & 0 & 0 & 0 & 0 & 0 & 0 & 0 \\
\hline $\mathrm{MgO}$ & 20,72 & 0,39 & 20,85 & 21,02 & 20,17 & 20,35 & 20,61 & 20,68 & 20,8 & 20.54 & 20,64 \\
\hline $\mathrm{CaO}$ & 30,3 & 54,74 & 31,43 & 30,51 & 32,36 & 32,65 & 32,26 & 30,67 & 31,82 & 31,31 & 31,65 \\
\hline $\mathrm{ZnO}$ & 0,04 & 0 & 0 & 0,06 & 0 & 0 & 0 & 0 & 0 & 0 & 0 \\
\hline $\mathrm{BaO}$ & 0 & 0 & 0 & 0 & 0 & 0 & 0 & 0 & 0 & 0 & 0 \\
\hline $\mathrm{CO} 2$ & 46,21 & 43,57 & 47,53 & 46,65 & 47,53 & 47,53 & 47,97 & 46,65 & 47,97 & 47,09 & 47,09 \\
\hline Total & 98,09 & 98,7 & 99,84 & 98,36 & 100,21 & 100,62 & 100,88 & 98,85 & 100,83 & 98,99 & 99,5 \\
\hline $\mathrm{Ca}$ & 1,019 & 1,975 & 1,038 & 1,024 & 1,069 & 1,075 & 1,056 & 1,024 & 1,042 & 1,044 & 1,052 \\
\hline $\mathrm{Mg}$ & 0,97 & 0,02 & 0,959 & 0,982 & 0,927 & 0,933 & 0,939 & 0,961 & 0,947 & 0,953 & 0,955 \\
\hline $\mathrm{Fe} 2$ & 0,002 & 0 & 0,001 & 0,002 & 0,004 & 0,002 & 0,001 & 0,005 & 0,004 & 0,001 & 0,003 \\
\hline $\mathrm{Si}$ & 0,023 & 0 & 0 & 0 & 0 & 0 & 0 & 0,02 & 0,003 & 0 & 0 \\
\hline $\mathrm{Mn}$ & 0 & 0 & 0 & 0 & 0 & 0 & 0 & 0 & 0 & 0 & 0 \\
\hline $\mathrm{Zn}$ & 0 & 0 & 0 & 0 & 0 & 0 & 0 & 0 & 0 & 0 & 0 \\
\hline $\mathrm{Sr}$ & 0 & 0 & 0 & 0 & 0 & 0 & 0 & 0 & 0 & 0 & 0 \\
\hline $\mathrm{Ba}$ & 0 & 0 & 0 & 0 & 0 & 0 & 0 & 0 & 0 & 0 & 0 \\
\hline C & 1,98 & 2 & 2 & 1,99 & 2 & 1,99 & 2 & 1,98 & 2 & 2 & 1,99 \\
\hline Cations & 2.014 & 1,995 & 1,998 & 2,008 & 2 & 2,01 & 1,996 & 2,01 & 1,996 & 1,998 & 2,01 \\
\hline
\end{tabular}


Anexo Tabela A-2. Análises químicas de calcita do Grupo Itaiacoca (proporção catiônica recalculada para 6 átomos de oxigênio por fórmula unitária).

\begin{tabular}{|c|c|c|c|c|c|c|c|c|c|c|c|c|c|}
\hline \multirow{3}{*}{$\begin{array}{l}\text { litotipo } \\
\text { amostra } \\
\text { análise }\end{array}$} & \multicolumn{13}{|c|}{ (a) talco xisto } \\
\hline & $02 \mathrm{AA}$ & 02AA & $02 \mathrm{AA}$ & $02 \mathrm{AB} 1$ & $02 \mathrm{AB} 1$ & $02 \mathrm{AB} 1$ & $02 \mathrm{ABI}$ & $02 \mathrm{AB} 1$ & $02 \mathrm{AB} 1$ & $02 \mathrm{AB} 1$ & $02 \mathrm{ABl}$ & $02 \mathrm{AB} 1$ & $02 \mathrm{CA}$ \\
\hline & 111 & 107 & 93 & 17 & 302 & 301 & 13 & 12 & 31 & 11 & 10 & 23 & 350 \\
\hline $\mathrm{SiO}_{2}$ & 0,03 & 0 & 0 & 0,03 & 0 & 0 & 0 & 0 & 0 & 0 & 0,01 & 0,02 & 0 \\
\hline SrO & 0 & 0,05 & 0,07 & 0,03 & 0,05 & 0,11 & 0,06 & 0,03 & 0,09 & 0 & 0,06 & 0,05 & 0 \\
\hline $\mathrm{FeO}$ & 0 & 0,06 & 0,02 & 0,04 & 0 & 0 & 0 & 0,01 & 0 & 0 & 0 & 0 & 0 \\
\hline $\mathrm{MnO}$ & 0,01 & 0,01 & 0 & 0 & 0 & 0 & 0 & 0 & 0 & 0,01 & 0,01 & 0,02 & 0,04 \\
\hline $\mathrm{MgO}$ & 0,67 & 0,96 & 1,13 & 0,41 & 0,36 & 0,36 & 0,43 & 0,39 & 0,39 & 0,39 & 0,4 & 0,44 & 0,4 \\
\hline $\mathrm{CaO}$ & 54,95 & 55,09 & 54,92 & 55,1 & 55,19 & 55,19 & 55,2 & 55,33 & 55,37 & 55,53 & 55,49 & 55,8 & 55,3 \\
\hline $\mathrm{ZnO}$ & 0 & 0,03 & 0 & 0 & 0,1 & 0,1 & 0,11 & 0 & 0,02 & 0 & 0 & 0,05 & 0 \\
\hline $\mathrm{BaO}$ & 0 & 0 & 0 & 0,08 & 0 & 0 & 0,08 & 0 & 0 & 0 & 0,02 & 0 & 0 \\
\hline $\mathrm{CO}_{2}$ & 44,01 & 44,01 & 44,45 & 43,57 & 43,57 & 43,57 & 43,57 & 44,01 & 44,01 & 44,01 & 44,01 & 44,45 & 44,01 \\
\hline Total & 99,67 & 100,21 & 100,59 & 99,26 & 99,27 & 99,33 & 99,45 & 99,77 & 99,88 & 99,94 & 100 & 100,83 & 99,75 \\
\hline $\mathrm{Ca}$ & 1,961 & 1,959 & 1,94 & 1,982 & 1,985 & 1,985 & 1,984 & 1,975 & 1,976 & 1,98 & 1,979 & 1,972 & 1,974 \\
\hline $\mathrm{Mg}$ & 0,033 & 0,048 & 0,056 & 0,021 & 0,018 & 0,018 & 0,021 & 0,019 & 0,019 & 0,019 & 0,02 & 0,022 & 0,02 \\
\hline $\mathrm{Fe} 2$ & 0 & 0,002 & 0,001 & 0,001 & 0 & 0 & 0 & 0 & 0 & 0 & 0 & 0 & 0 \\
\hline $\mathrm{Si}$ & 0,001 & 0 & 0 & 0,001 & 0 & 0 & 0 & 0 & 0 & 0 & 0 & 0,001 & 0 \\
\hline $\mathrm{Mn}$ & 0 & 0 & 0 & 0 & 0 & 0 & 0 & 0 & 0 & 0 & 0 & 0,001 & 0,001 \\
\hline $\mathrm{Zn}$ & 0 & 0 & 0 & 0 & 0 & 0 & 0 & 0 & 0 & 0 & 0 & 0 & 0 \\
\hline $\mathrm{Sr}$ & 0 & 0 & 0 & 0 & 0 & 0 & 0 & 0 & 0 & 0 & 0 & 0 & 0 \\
\hline $\mathrm{Ba}$ & 0 & 0 & 0 & 0 & 0 & 0 & 0 & 0 & 0 & 0 & 0 & 0 & 0 \\
\hline $\mathrm{C}$ & 2 & 1,99 & 2 & 2 & 2 & 2 & 2 & 2 & 2 & 2 & 2 & 2 & 2 \\
\hline Cations & 1,995 & 2,009 & 1,997 & 2,005 & 2,003 & 2,003 & 2,005 & 1,994 & 1,995 & 1,999 & 1,999 & 1,996 & 1,995 \\
\hline
\end{tabular}


Anexo Tabela A-2. (continuação).

\begin{tabular}{|c|c|c|c|c|c|c|c|c|c|c|c|c|c|}
\hline \multirow{3}{*}{$\begin{array}{l}\text { litotipo } \\
\text { amostra } \\
\text { análise }\end{array}$} & \multicolumn{9}{|c|}{ (a) talco xisto } & \multicolumn{4}{|c|}{ (c) márnore dolomítico } \\
\hline & $02 \mathrm{CA}$ & $02 \mathrm{CA}$ & $02 \mathrm{CA}$ & $02 \mathrm{CA}$ & $02 \mathrm{CA}$ & $02 \mathrm{CC}$ & $02 \mathrm{CI}$ & $02 \mathrm{CI}$ & $02 \mathrm{Cl}$ & 05aae & 05bacl & 05bacl & $05 \mathrm{bac} 1$ \\
\hline & 373 & 349 & 372 & 348 & 340 & 519 & 548 & 553 & 550 & 63 & 86 & 76 & 74 \\
\hline $\mathrm{SiO}_{2}$ & 0,02 & 0,01 & 0 & 0 & 0 & 0,03 & 0,03 & 0,06 & 0,04 & 0 & 0,03 & 0,02 & 0,02 \\
\hline $\mathrm{SrO}$ & 0 & 0 & 0 & 0 & 0,04 & 0 & 0 & 0 & 0 & 0,06 & 0 & 0 & 0,04 \\
\hline $\mathrm{FeO}$ & 0 & 0 & 0 & 0,05 & 0 & 0 & 0,03 & 0 & 0 & 0,01 & 0,04 & 0,04 & 0 \\
\hline $\mathrm{MnO}$ & 0 & 0 & 0 & 0 & 0 & 0 & 0,04 & 0 & 0 & 0,07 & 0 & 0,01 & 0 \\
\hline $\mathrm{MgO}$ & 0,4 & 0,4 & 0,43 & 0,44 & 0,37 & 0,85 & 0,2 & 0,12 & 0,18 & 0,24 & 0,35 & 0,15 & 0,1 \\
\hline $\mathrm{CaO}$ & 55,24 & 55,39 & 55,49 & 55,77 & 56,06 & 54,99 & 55,36 & 55,59 & 55,57 & 54,99 & 55,016 & 55,53 & 55,92 \\
\hline $\mathrm{ZnO}$ & 0,08 & 0 & 0 & 0 & 0 & 0 & 0 & 0 & 0 & 0 & 0 & 0 & 0 \\
\hline $\mathrm{BaO}$ & 0 & 0 & 0 & 0 & 0 & 0 & 0 & 0 & 0 & 0,06 & 0 & 0 & 0,09 \\
\hline $\mathrm{CO}_{2}$ & 44,01 & 44,01 & 44,01 & 44,01 & 44,45 & 44,01 & 43,57 & 43,57 & 43,57 & 43,57 & 43,57 & 43.57 & 44,01 \\
\hline Total & 99,75 & 99,81 & 99,93 & 100,27 & 100,92 & 99,88 & 99,23 & 99,34 & 99,36 & 99 & 99,01 & 99,32 & 100,18 \\
\hline $\mathrm{Ca}$ & 1,972 & 1,977 & 1,979 & 1,985 & 1,98 & 1,959 & 1,992 & 1,998 & 1,997 & 1,982 & 1,981 & 1,997 & 1,993 \\
\hline $\mathrm{Mg}$ & 0,02 & 0,02 & 0,021 & 0,022 & 0,018 & 0,042 & 0,01 & 0,006 & 0,009 & 0,012 & 0,018 & 0,008 & 0,005 \\
\hline $\mathrm{Fe} 2$ & 0 & 0 & 0 & 0,001 & 0 & 0 & 0,001 & 0 & 0 & 0 & 0,001 & 0,001 & 0 \\
\hline $\mathrm{Si}$ & 0,001 & 0 & 0 & 0 & 0 & 0,001 & 0,001 & 0,002 & 0,001 & 0 & 0,001 & 0,001 & 0,001 \\
\hline Mn & 0 & 0 & 0 & 0 & 0 & 0 & 0,001 & 0 & 0 & 0,002 & 0 & 0 & 0 \\
\hline $\mathrm{Zn}$ & 0 & 0 & 0 & 0 & 0 & 0 & 0 & 0 & 0 & 0 & 0 & 0 & 0 \\
\hline $\mathrm{Sr}$ & 0 & 0 & 0 & 0 & 0 & 0 & 0 & 0 & 0 & 0 & 0 & 0 & 0 \\
\hline $\mathrm{Ba}$ & 0 & 0 & 0 & 0 & 0 & 0 & 0 & 0 & 0 & 0 & 0 & 0 & 0 \\
\hline C & 2 & 2 & 2 & 2 & 2 & 2 & 2 & 2 & 2 & 2 & 2 & 2 & 2 \\
\hline Cations & 1,993 & 1,997 & 2 & 2,008 & 1,998 & 2,002 & 2,005 & 2,006 & 2,007 & 1,996 & 2,001 & 2,007 & 1,999 \\
\hline
\end{tabular}


Anexo Tabela A-2. (continuaçāo).

\begin{tabular}{|c|c|c|c|c|c|c|c|c|c|c|c|c|c|}
\hline \multirow{3}{*}{$\begin{array}{l}\text { litotipo } \\
\text { amostra } \\
\text { análise }\end{array}$} & \multicolumn{7}{|c|}{ (c) mármore dolomítico } & \multicolumn{6}{|c|}{ (a) talco xisto } \\
\hline & 05bac 1 & 05 bac 1 & $07 \mathrm{y} 1$ & $07 \mathrm{~J}_{1}$ & $07 \mathrm{~J} 1$ & 0711 & $07 \mathrm{~J} 1$ & $22 \mathrm{BD}$ & $22 \mathrm{BD}$ & $22 \mathrm{BD}$ & $22 \mathrm{BD}$ & $22 \mathrm{BD}$ & $22 \mathrm{D} 1$ \\
\hline & 75 & 80 & 396 & 380 & 379 & 382 & 395 & 496 & 494 & 489 & 493 & 492 & 508 \\
\hline $\mathrm{SiO}_{2}$ & 0,03 & 0,17 & 0 & 0 & 0 & 0,02 & 0,01 & 0 & 0 & 0,02 & 0,02 & 0,02 & 0,01 \\
\hline Sro & 0,01 & 0 & 0 & 0,05 & 0,05 & 0,07 & 0 & 0 & 0 & 0 & 0 & 0 & 0 \\
\hline $\mathrm{FeO}$ & 0 & 0 & 0,07 & 0 & 0,08 & 0 & 0,09 & 0 & 0 & 0,05 & 0,07 & 0,04 & 0 \\
\hline $\mathrm{MnO}$ & 0 & 0,01 & 0 & 0,07 & 0,11 & 0,1 & 0 & 0 & 0 & 0 & 0 & 0 & 0 \\
\hline $\mathrm{MgO}$ & 0,06 & 0,19 & 0,83 & 0,29 & 0,26 & 0,3 & 2,22 & 0,47 & 0,47 & 0,51 & 0,45 & 0,49 & 1 \\
\hline $\mathrm{CaO}$ & 56,17 & 55,99 & 54,56 & 55,13 & 55,17 & 55,65 & 53,66 & 55,02 & 55,08 & 55 & 55,21 & 55,4 & 54,57 \\
\hline $\mathrm{ZnO}$ & 0 & 0 & 0 & 0 & 0 & 0 & 0 & 0 & 0 & 0 & 0 & 0 & 0 \\
\hline $\mathrm{BaO}$ & 0,01 & 0,04 & 0 & 0 & 0 & 0 & 0 & 0 & 0 & 0 & 0 & 0 & 0 \\
\hline $\mathrm{CO}_{2}$ & 44,01 & 44,01 & 43,57 & 43,57 & 43,57 & 44,01 & 44.89 & 43,57 & 43,57 & 43,57 & 43,57 & 44,01 & 43,57 \\
\hline Total & 100,29 & 100,41 & 99,03 & 99,11 & 99,24 & 100,15 & 100,87 & 99,06 & 99,12 & 99,15 & 99,32 & 99,96 & 99,15 \\
\hline $\mathrm{Ca}$ & 2 & 1,991 & 1,962 & 1,985 & 1,985 & 1,983 & 1,88 & 1,98 & 1,982 & 1,978 & 1,984 & 1,975 & 1,96 \\
\hline $\mathrm{Mg}$ & 0,003 & 0,009 & 0,042 & 0,015 & 0,013 & 0,015 & 0,108 & 0,024 & 0,024 & 0,026 & 0,023 & 0,024 & 0,05 \\
\hline $\mathrm{Fe} 2$ & 0 & 0 & 0,002 & 0 & 0,002 & 0 & 0,002 & 0 & 0 & 0,001 & 0,002 & 0,001 & 0 \\
\hline $\mathrm{Si}$ & 0,001 & 0,006 & 0 & 0 & 0 & 0,001 & 0 & 0 & 0 & 0,001 & 0,001 & 0,001 & 0 \\
\hline $\mathrm{Mn}$ & 0 & 0 & 0 & 0,002 & 0,003 & 0,003 & 0 & 0 & 0 & 0 & 0 & 0 & 0 \\
\hline $\mathrm{Zn}$ & 0 & 0 & 0 & 0 & 0 & 0 & 0 & 0 & 0 & 0 & 0 & 0 & 0 \\
\hline $\mathrm{Sr}$ & 0 & 0 & 0 & 0 & 0 & 0 & 0 & 0 & 0 & 0 & 0 & 0 & 0 \\
\hline $\mathrm{Ba}$ & 0 & 0 & 0 & 0 & 0 & 0 & 0 & 0 & 0 & 0 & 0 & 0 & 0 \\
\hline C & 2 & 1,99 & 2 & 2 & 2 & 2 & 2 & 2 & 2 & 2 & 2 & 2 & 1,99 \\
\hline Cations & 2,004 & 2,006 & 2,006 & 2,002 & 2,003 & 2,002 & 1,99 & 2,004 & 2,006 & 2,006 & 2,01 & 2,001 & 2,01 \\
\hline
\end{tabular}


Anexo Tabela A-2. (continuação).

\begin{tabular}{|c|c|c|c|c|c|c|c|c|c|c|c|c|c|}
\hline \multirow{3}{*}{$\begin{array}{l}\text { litotipo } \\
\text { amostra } \\
\text { análise }\end{array}$} & \multicolumn{6}{|c|}{ (a) talco xisto } & \multicolumn{7}{|c|}{ (b) talco maciço fino } \\
\hline & $22 \mathrm{D} 1$ & $22 \mathrm{DI}$ & $22 \mathrm{~L}$ & $22 \mathrm{~L}$ & $22 \mathrm{~L}$ & $22 \mathrm{~L}$ & $40 \mathrm{~A}$ & $40 \mathrm{~A}$ & $40 \mathrm{~A}$ & $40 \mathrm{~A}$ & $42 \mathrm{~A}$ & $42^{\mathrm{a}}$ & $42 \mathrm{~A}$ \\
\hline & 510 & 513 & 433 & 428 & 446 & 442 & 455 & 458 & 456 & 461 & 317 & 316 & 331 \\
\hline $\mathrm{SiO}_{2}$ & 0,02 & 0 & 0,01 & 0,02 & 0,04 & 0 & 0,04 & 0,02 & 0 & 0,05 & 0 & 0 & 0 \\
\hline SrO & 0 & 0 & 0 & 0 & 0 & 0 & 0 & 0 & 0 & 0 & 0 & 0 & 0 \\
\hline $\mathrm{FeO}$ & 0,1 & 0,05 & 0,05 & 0,04 & 0 & 0,04 & 0,04 & 0,04 & 0 & 0 & 0 & 0 & 0 \\
\hline $\mathrm{MnO}$ & 0 & 0 & 0 & 0 & 0 & 0 & 0 & 0 & 0 & 0 & 0 & 0 & 0 \\
\hline $\mathrm{MgO}$ & 0,92 & 1,04 & 0,68 & 1,04 & 0,93 & 0,98 & 0,13 & 0,16 & 0,19 & 0,31 & 0,52 & 0,71 & 0,3 \\
\hline $\mathrm{CaO}$ & 54,64 & 54,98 & 54,97 & 54,01 & 54,89 & 54,95 & 55,31 & 55,7 & 55,78 & 56,06 & 55,12 & 55,04 & 55,45 \\
\hline $\mathrm{ZnO}$ & 0 & 0 & 0 & 0,7 & 0 & 0 & 0 & 0 & 0,08 & 0 & 0 & 0 & 0.05 \\
\hline $\mathrm{BaO}$ & 0 & 0 & 0 & 0 & 0 & 0 & 0 & 0 & 0 & 0 & 0 & 0 & 0 \\
\hline $\mathrm{CO}_{2}$ & 43,57 & 44,45 & 44,01 & 44,01 & 44,01 & 44,01 & 43,57 & 43,57 & 43,57 & 44,45 & 43,57 & 44,01 & 44,01 \\
\hline Total & 99,25 & 100,52 & 99,72 & 99,82 & 99,87 & 99,98 & 99,09 & 99,49 & 99,62 & 100,87 & 99,21 & 99,76 & 99,81 \\
\hline $\mathrm{Ca}$ & 1,962 & 1,943 & 1,962 & 1,927 & 1,955 & 1,957 & 1,992 & 2,001 & 2,002 & 1,98 & 1,982 & 1,964 & 1,98 \\
\hline $\mathrm{Mg}$ & 0,046 & 0,051 & 0,034 & 0,052 & 0,046 & 0,049 & 0,007 & 0,008 & 0,009 & 0,015 & 0,026 & 0,035 & 0,015 \\
\hline $\mathrm{Fe} 2$ & 0,003 & 0,001 & 0,001 & 0,001 & 0 & 0,001 & 0,001 & 0,001 & 0 & 0 & 0 & 0 & 0 \\
\hline $\mathrm{Si}$ & 0,001 & 0 & 0 & 0,001 & 0,001 & 0 & 0,001 & 0,001 & 0 & 0,002 & 0 & 0 & 0 \\
\hline Mn & 0 & 0 & 0 & 0 & 0 & 0 & 0 & 0 & 0 & 0 & 0 & 0 & 0 \\
\hline $\mathrm{Zn}$ & 0 & 0 & 0 & 0,02 & 0 & 0 & 0 & 0 & 0 & 0 & 0 & 0 & 0 \\
\hline $\mathrm{Sr}$ & 0 & 0 & 0 & 0 & 0 & 0 & 0 & 0 & 0 & 0 & 0 & 0 & 0 \\
\hline $\mathrm{Ba}$ & 0 & 0 & 0 & 0 & 0 & 0 & 0 & 0 & 0 & 0 & 0 & 0 & 0 \\
\hline $\mathrm{C}$ & 1,99 & 2 & 2 & 2 & 2 & 2 & 2 & 1,99 & 1,99 & 2 & 2 & 2 & 2 \\
\hline Cations & 2,012 & 1,995 & 1,997 & 2,001 & 2,002 & 2,007 & 2,001 & 2,011 & 2,011 & 1,997 & 2,008 & 1,999 & 1,995 \\
\hline
\end{tabular}


Anexo Tabela A-2. (continuação).

\begin{tabular}{|c|c|c|c|c|c|c|c|c|c|c|c|c|}
\hline \multirow{3}{*}{$\begin{array}{l}\text { litotipo } \\
\text { amostra } \\
\text { análise }\end{array}$} & \multicolumn{4}{|c|}{ (b) talco maciço fino } & \multicolumn{6}{|c|}{ (c) mármore dolomítico } & \multicolumn{2}{|c|}{ (a) talco xisto } \\
\hline & $42 \mathrm{~A}$ & $42 \mathrm{~A}$ & $42 B$ & $42 \mathrm{~B}$ & $43 \mathrm{C}$ & $43 \mathrm{C}$ & $43 \mathrm{C}$ & $43 \mathrm{C}$ & $43 \mathrm{C}$ & $43 \mathrm{C}$ & $55 \mathrm{C}$ & $55 \mathrm{C}$ \\
\hline & 335 & 332 & 504 & 502 & 414 & 420 & 415 & 416 & 419 & 417 & 357 & 352 \\
\hline $\mathrm{SiO}_{2}$ & 0,01 & 0 & 0 & 0 & 0 & 0 & 0 & 0,02 & 0,02 & 0,04 & 0 & 0,03 \\
\hline Sro & 0 & 0 & 0 & 0 & 0 & 0 & 0 & 0 & 0 & 0 & 0 & 0,03 \\
\hline $\mathrm{FeO}$ & 0 & 0 & 0 & 0 & 0,07 & 0,04 & 0 & 0 & 0 & 0 & 0 & 0 \\
\hline $\mathrm{MnO}$ & 0 & 0 & 0,04 & 0 & 0 & 0,03 & 0,03 & 0,04 & 0,05 & 0 & 0 & 0 \\
\hline $\mathrm{MgO}$ & 0,18 & 0,2 & 0,16 & 0,24 & 0,6 & 1,1 & 0,61 & 0,4 & 1,02 & 0,29 & 0,6 & 0,27 \\
\hline $\mathrm{CaO}$ & 55,87 & 56,21 & 55,73 & 55,64 & 55,07 & 54,15 & 54,91 & 55,27 & 54,67 & 55,71 & 55,04 & 55,98 \\
\hline $\mathrm{ZnO}$ & 0 & 0 & 0 & 0 & 0 & 0 & 0 & 0 & 0 & 0 & 0 & 0 \\
\hline $\mathrm{BaO}$ & 0 & 0 & 0 & 0 & 0 & 0 & 0 & 0 & 0 & 0 & 0 & 0 \\
\hline $\mathrm{CO}_{2}$ & 44,01 & 44,01 & 43,57 & 44,01 & 43,57 & 44,01 & 44,01 & 44,01 & 44,01 & 44,01 & 43,57 & 44,45 \\
\hline Total & 100,07 & 100,42 & 99,5 & 99,89 & 99,31 & 99,33 & 99,56 & 99,74 & 99,77 & 100,05 & 99,21 & 100,76 \\
\hline $\mathrm{Ca}$ & 1,992 & 2 & 2,002 & 1,986 & 1,979 & 1,935 & 1,962 & 1,973 & 1,949 & 1,986 & 1,979 & $\mathrm{I}, 979$ \\
\hline $\mathrm{Mg}$ & 0,009 & 0,01 & 0,008 & 0,012 & 0,03 & 0,055 & 0,03 & 0,02 & 0,051 & 0,014 & 0,03 & 0,013 \\
\hline $\mathrm{Fe} 2$ & 0 & 0 & 0 & 0 & 0,002 & 0,001 & 0 & 0 & 0 & 0 & 0 & 0 \\
\hline $\mathrm{Si}$ & 0 & 0 & 0 & 0 & 0 & 0 & 0 & 0,001 & 0,001 & 0,001 & 0 & 0,001 \\
\hline $\mathrm{Mn}$ & 0 & 0 & $0,00 \mathrm{I}$ & 0 & 0 & 0,001 & 0,001 & 0,001 & 0,001 & 0 & 0 & 0 \\
\hline $\mathrm{Zn}$ & 0 & 0 & 0 & 0 & 0 & 0 & 0 & 0 & 0 & 0 & 0 & 0 \\
\hline Sr & 0 & 0 & 0 & 0 & 0 & 0 & 0 & 0 & 0 & 0 & 0 & 0 \\
\hline $\mathrm{Ba}$ & 0 & 0 & 0 & 0 & 0 & 0 & 0 & 0 & 0 & 0 & 0 & 0 \\
\hline $\mathrm{C}$ & 2 & 2 & 1,99 & 2 & 1,99 & 2 & 2 & 2 & 2 & 2 & 2 & 2 \\
\hline Cations & 2,001 & 2,01 & 2,011 & 1,998 & 2,011 & 1,992 & 1,993 & 1,995 & 2,002 & 2,001 & 2,009 & 1,993 \\
\hline
\end{tabular}


Anexo Tabela A-3. Análises químicas de talco do Grupo Itaiacoca (proporçāo catiônica recalculada para 22 átomos de oxigênio por fórmula unitária).

\begin{tabular}{|c|c|c|c|c|c|c|c|c|c|c|c|c|c|c|}
\hline \multirow{3}{*}{$\begin{array}{l}\text { litotipo } \\
\text { amostra } \\
\text { análise }\end{array}$} & \multicolumn{14}{|c|}{ (a) talco xisto } \\
\hline & $02 \mathrm{CC}$ & $02 \mathrm{CC}$ & $02 \mathrm{CC}$ & $02 \mathrm{CC}$ & $02 \mathrm{CC}$ & $02 \mathrm{CC}$ & $02 \mathrm{CC}$ & $02 \mathrm{CC}$ & $02 \mathrm{CC}$ & $02 \mathrm{CC}$ & $02 \mathrm{CC}$ & $02 \mathrm{CC}$ & 02AA & 02AA \\
\hline & 600 & 601 & 602 & 603 & 604 & 605 & 606 & 607 & 608 & 609 & 610 & 611 & 116 & 117 \\
\hline $\mathrm{SiO}_{2}$ & 61,59 & 61,13 & 62,01 & 62,43 & 61,75 & 62,43 & 62,3 & 62,08 & 62,15 & 62,14 & 61,65 & 61,73 & 63,79 & 63,67 \\
\hline $\mathrm{Al}_{2} \mathrm{O}_{3}$ & 0,17 & 0,19 & 0,18 & 0,19 & 0,15 & 0,12 & 0,18 & 0,15 & 0,18 & 0,18 & 0,26 & 0,23 & 0,53 & 0,8 \\
\hline $\mathrm{FeO}$ & 0,04 & 0,09 & 0,08 & 0,07 & 0,08 & 0,05 & 0,09 & 0,05 & 0,08 & 0,06 & 0,07 & 0,05 & 0,01 & 0,03 \\
\hline $\mathrm{MnO}$ & 0 & 0,01 & 0,02 & 0 & 0 & 0,01 & 0 & 0 & 0 & 0,01 & 0 & 0 & 0 & 0 \\
\hline $\mathrm{MgO}$ & 31,59 & 31,8 & 31,61 & 31,88 & 31,7 & 31,72 & 31,88 & 31,64 & 31,65 & 31,95 & 31,54 & 31,37 & 31,71 & 31,41 \\
\hline $\mathrm{NiO}$ & 0 & 0 & 0 & 0 & 0 & 0 & 0 & 0 & 0 & 0 & 0 & 0 & 0 & 0,05 \\
\hline $\mathrm{CaO}$ & 0,03 & 0,03 & 0,04 & 0,04 & 0,05 & 0,06 & 0,05 & 0,01 & 0,04 & 0,1 & 0,08 & 0,09 & 0,02 & 0,03 \\
\hline $\mathrm{CoO}$ & 0 & 0 & 0 & 0 & 0 & 0 & 0 & 0 & 0 & 0 & 0 & 0 & 0 & 0 \\
\hline Total & 93,42 & 93,25 & 93,94 & 94,61 & 93,73 & 94,39 & 94,5 & 93,93 & 94,1 & 94,44 & 93,6 & 93,47 & 96,06 & 95,99 \\
\hline $\mathrm{Si}$ & 7,941 & 7,905 & 7,951 & 7,947 & 7,938 & 7,963 & 7,942 & 7,957 & 7,954 & 7,930 & 7,935 & 7,953 & 7,982 & 7,973 \\
\hline AlIV & 0,026 & 0,029 & 0,027 & 0,028 & 0,023 & 0,018 & 0,027 & 0,023 & 0,027 & 0,027 & 0,039 & 0,035 & 0,018 & 0,027 \\
\hline Sum_T & 7,967 & 7,934 & 7,978 & 7,975 & 7,961 & 7,981 & 7,969 & 7,980 & 7,981 & 7,957 & 7,974 & 7,988 & 8,000 & 8,000 \\
\hline AIVI & 0,000 & 0,000 & 0,000 & 0,000 & 0,000 & 0,000 & 0,000 & 0,000 & 0,000 & 0,000 & 0,000 & 0,000 & 0,060 & 0,091 \\
\hline $\mathrm{Fe} 2$ & 0,004 & 0,010 & 0,009 & 0,007 & 0,009 & 0,005 & 0,010 & 0,005 & 0,009 & 0,006 & 0,008 & 0,005 & 0,001 & 0,003 \\
\hline $\mathrm{Mn}$ & 0,000 & 0,001 & 0,002 & 0,000 & 0,000 & 0,001 & 0,000 & 0,000 & 0,000 & 0,001 & 0,000 & 0,000 & 0,000 & 0,000 \\
\hline $\mathrm{Mg}$ & 6,072 & 6,131 & 6,042 & 6,050 & 6,075 & 6,032 & 6,059 & 6,046 & 6,038 & 6,078 & 6,052 & 6,025 & 5,915 & 5,864 \\
\hline $\mathrm{Ni}$ & 0,000 & 0,000 & 0,000 & 0,000 & 0,000 & 0,000 & 0,000 & 0,000 & 0,000 & 0,000 & 0,000 & 0,000 & 0,000 & 0,010 \\
\hline $\mathrm{Ca}$ & 0,004 & 0,004 & 0,005 & 0,005 & 0,007 & 0,008 & 0,007 & 0,001 & 0,005 & 0,014 & 0,011 & 0,012 & 0,003 & 0.004 \\
\hline Co & 0,000 & 0,000 & 0,000 & 0,000 & 0,000 & 0,000 & 0,000 & 0,000 & 0.000 & 0,000 & 0,000 & 0,000 & 0,000 & 0,000 \\
\hline Cations & 14,047 & 14,080 & 14,036 & 14,037 & 14,052 & 14,027 & 14,045 & 14,032 & 14,033 & 14,056 & 14,045 & 14,030 & 13,979 & 13,972 \\
\hline
\end{tabular}


Anexo Tabela A-3. (continuação).

\begin{tabular}{|c|c|c|c|c|c|c|c|c|c|c|c|c|c|}
\hline \multirow{3}{*}{$\begin{array}{l}\text { litotipo } \\
\text { amostra } \\
\text { análise } \\
\end{array}$} & \multicolumn{13}{|c|}{ (a) talco xisto } \\
\hline & $02 \mathrm{AA}$ & $02 \mathrm{AA}$ & $02 \mathrm{AA}$ & $02 \mathrm{AA}$ & $02 \mathrm{AA}$ & $02 \mathrm{AA}$ & $02 \mathrm{AA}$ & $02 \mathrm{AA}$ & $02 \mathrm{AA}$ & $02 \mathrm{AA}$ & 02AA & $02 \mathrm{AA}$ & $02 \mathrm{AB} 1$ \\
\hline & 118 & 119 & 121 & 122 & 123 & 124 & 125 & 126 & 127 & 128 & 129 & 130 & 32 \\
\hline $\mathrm{SiO}_{2}$ & 60,71 & 63,07 & 63,41 & 62,24 & 62,5 & 62,87 & 62,26 & 62,23 & 63,14 & 62,29 & 60,37 & 63,02 & 62,4 \\
\hline $\mathrm{Al}_{2} \mathrm{O}_{3}$ & 3,33 & 0,41 & 0,55 & 0,87 & 0,35 & 0,24 & 0,88 & 0,85 & 0,66 & 0,38 & 3,19 & 0,44 & 0.81 \\
\hline $\mathrm{FeO}$ & 0,04 & 0 & 0,02 & 0,03 & 0,04 & 0,03 & 0,03 & 0,05 & 0 & 0 & 0 & 0 & 0,01 \\
\hline $\mathrm{MnO}$ & 0 & 0,04 & 0,02 & 0 & 0 & 0,02 & 0 & 0 & 0,02 & 0 & 0 & 0 & 0 \\
\hline $\mathrm{MgO}$ & 30,61 & 31,94 & 31,79 & 31,76 & 32,01 & 31,89 & 31,6 & 31,01 & 31,42 & 31,68 & 29,93 & 31,66 & 31,37 \\
\hline $\mathrm{NiO}$ & 0 & 0,01 & 0 & 0,02 & 0 & 0 & 0 & 0 & 0 & 0,03 & 0 & 0 & 0 \\
\hline $\mathrm{CaO}$ & 0,05 & 0,02 & 0,02 & 0,08 & 0,02 & 0,02 & 0,06 & 0,06 & 0,02 & 0 & 0,27 & 0,04 & 0,01 \\
\hline $\mathrm{CoO}$ & 0 & 0 & 0 & 0 & 0 & 0 & 0 & 0 & 0 & 0 & 0 & 0 & 0 \\
\hline Total & 94,74 & 95,49 & 95,81 & 95 & 94,92 & 95,07 & 94,83 & 94,2 & 95,26 & 94,38 & 93,76 & 95,16 & 94,6 \\
\hline $\mathrm{Si}$ & 7,719 & 7,950 & 7,961 & 7,892 & 7,930 & 7,960 & 7,905 & 7,946 & 7,968 & 7,944 & 7,754 & 7,965 & 7,934 \\
\hline AlIV & 0,281 & 0,050 & 0,039 & 0,108 & 0,052 & 0,036 & 0,095 & 0,054 & 0,032 & 0,056 & 0,246 & 0,035 & 0,066 \\
\hline Sum_T & 8,000 & 8,000 & 8,000 & 8,000 & 7,982 & 7,996 & 8,000 & 8,000 & 8,000 & 8,000 & 8,000 & 8,000 & 8,000 \\
\hline AlVI & 0,218 & 0,011 & 0,042 & 0,022 & 0,000 & 0,000 & 0,037 & 0,074 & 0,066 & 0,001 & 0,237 & 0,030 & 0,055 \\
\hline $\mathrm{Fe} 2$ & 0,004 & 0,000 & 0,002 & 0,003 & 0,004 & 0,003 & 0,003 & 0,005 & 0,000 & 0,000 & 0,000 & 0,000 & 0,001 \\
\hline $\mathrm{Mn}$ & 0,000 & 0,004 & 0,002 & 0,000 & 0,000 & 0,002 & 0,000 & 0,000 & 0,002 & 0,000 & 0,000 & 0,000 & 0,000 \\
\hline $\mathrm{Mg}$ & 5,802 & 6,002 & 5,950 & 6,004 & 6,055 & 6,019 & 5,981 & 5,903 & 5,911 & 6,023 & 5,731 & 5,966 & 5,946 \\
\hline $\mathrm{Ni}$ & 0,000 & 0,000 & 0,000 & 0.000 & 0,000 & 0,000 & 0,000 & 0,000 & 0,000 & 0,000 & 0,000 & 0,000 & 0,000 \\
\hline $\mathrm{Ca}$ & 0,007 & 0,003 & 0,003 & 0,011 & 0,003 & 0,003 & 0,008 & 0,008 & 0,003 & 0,000 & 0,037 & 0,005 & 0,001 \\
\hline $\mathrm{Co}$ & 0,000 & 0,000 & 0,000 & 0,000 & 0,000 & 0,000 & 0,000 & 0,000 & 0,000 & 0,000 & 0,000 & 0,000 & 0,000 \\
\hline Cations & 14,031 & 14,020 & 13,999 & 14,040 & 14,044 & 14,023 & 14,029 & 13,990 & 13,982 & 14,024 & 14,005 & 14,001 & 14,003 \\
\hline
\end{tabular}


Anexo Tabela A-3. (continuação).

\begin{tabular}{|c|c|c|c|c|c|c|c|c|c|c|c|c|}
\hline \multirow{3}{*}{$\begin{array}{l}\text { litotipo } \\
\text { amostra } \\
\text { análise }\end{array}$} & \multicolumn{12}{|c|}{ (a) talco xisto } \\
\hline & $02 \mathrm{AB} 1$ & 22D1 & 22D1 & $22 \mathrm{D} 1$ & $22 \mathrm{D} 1$ & $02 \mathrm{AB} 1$ & $02 \mathrm{ABI}$ & 02AB1 & $02 \mathrm{AB} 1$ & $02 \mathrm{AB} 1$ & $02 \mathrm{AB} 1$ & $02 \mathrm{AB} 1$ \\
\hline & 33 & 146 & 147 & 148 & 149 & 40 & 41 & 42 & 43 & 44 & 45 & 46 \\
\hline $\mathrm{SiO}_{2}$ & 62,21 & 61,98 & 60.52 & 62,87 & 62,34 & 62,57 & 63,1 & 62,7 & 63,53 & 62,44 & 63,12 & 63,12 \\
\hline $\mathrm{Al}_{2} \mathrm{O}_{3}$ & 1,2 & 0,34 & 0,83 & 0,2 & 0,18 & 0.99 & 0,75 & 0,72 & 0,4 & 0.77 & 0,39 & 0,54 \\
\hline $\mathrm{FeO}$ & 0,01 & 0,38 & 0,39 & 0,39 & 0,4 & 0,04 & 0 & 0 & 0 & 0 & 0,04 & 0,05 \\
\hline $\mathrm{MnO}$ & 0,01 & 0,02 & 0 & 0 & 0 & 0,01 & 0 & 0 & 0 & 0,02 & 0 & 0,04 \\
\hline MgO & 31,29 & 30,95 & 30,74 & 31,29 & 30,99 & 31,19 & 31,35 & 31,39 & 31,31 & 31,29 & 31,56 & 31,72 \\
\hline $\mathrm{NiO}$ & 0,01 & 0 & 0 & 0,02 & 0,03 & 0 & 0 & 0 & 0,01 & 0 & 0 & 0,01 \\
\hline $\mathrm{CaO}$ & 0,03 & 0,75 & 1,22 & 0,17 & 0,04 & 0,03 & 0,04 & 0,02 & 0,04 & 0,06 & 0,03 & 0,02 \\
\hline $\mathrm{CoO}$ & 0,04 & 0 & 0 & 0 & 0 & 0 & 0 & 0,02 & 0,01 & 0 & 0,03 & 0,02 \\
\hline Total & 94,8 & 94,42 & 93,7 & 94,94 & 93,98 & 94,83 & 95,24 & 94,85 & 95,3 & 94,58 & 95,17 & 95,52 \\
\hline $\mathrm{Si}$ & 7,898 & 7,935 & 7,834 & 7,983 & 7,992 & 7,936 & 7,964 & 7,950 & 8,009 & 7,942 & 7,978 & 7,953 \\
\hline AlrV & 0,102 & 0,051 & 0,127 & 0,017 & 0,008 & 0,064 & 0,036 & 0,050 & 0,000 & 0,058 & 0,022 & 0,047 \\
\hline Sum_T & 8,000 & 7,986 & 7,961 & 8,000 & 8,000 & 8,000 & 8,000 & 8,000 & 8,009 & 8,000 & 8,000 & 8,000 \\
\hline AlVI & 0,077 & 0,000 & 0,000 & 0,013 & 0,019 & 0,084 & 0,075 & 0,058 & 0,059 & 0,057 & 0,036 & 0,033 \\
\hline $\mathrm{Fe} 2$ & 0,001 & 0,041 & 0,042 & 0,041 & 0,043 & 0,004 & 0,000 & 0,000 & 0,000 & 0,000 & 0,004 & 0,005 \\
\hline $\mathrm{Mn}$ & 0,001 & 0,002 & 0,000 & 0,000 & 0,000 & 0,001 & 0,000 & 0,000 & 0,000 & 0,002 & 0,000 & 0,004 \\
\hline $\mathrm{Mg}$ & 5,922 & 5,907 & 5,932 & 5,923 & 5,923 & 5,897 & 5,899 & 5,933 & 5,885 & 5,933 & 5,946 & 5,958 \\
\hline $\mathrm{Ni}$ & 0,000 & 0,000 & 0,000 & 0,000 & 0,000 & 0.000 & 0,000 & 0,000 & 0,000 & 0,000 & 0,000 & 0,000 \\
\hline $\mathrm{Ca}$ & 0,004 & 0,103 & 0,169 & 0,023 & 0,005 & 0,004 & 0,005 & 0,003 & 0,005 & 0,008 & 0,004 & 0,003 \\
\hline Co & 0,000 & 0,000 & 0,000 & 0,000 & 0,000 & 0,000 & 0,000 & 0,000 & 0,000 & 0,000 & 0,000 & 0,000 \\
\hline Cations & 14,005 & 14,039 & 14,104 & 14,000 & 13,990 & 13,990 & 13,979 & 13,994 & 13,958 & 14,000 & 13,990 & 14,003 \\
\hline
\end{tabular}


Anexo Tabela A-3. (continuaçāo).

\begin{tabular}{lccccccccccc}
\hline litotipo & \multicolumn{10}{c}{ (a) talco xisto } \\
amostra & $22 \mathrm{C}$ & $22 \mathrm{C}$ & $22 \mathrm{C}$ & $22 \mathrm{C}$ & $22 \mathrm{C}$ & $22 \mathrm{C}$ & $22 \mathrm{C}$ & $22 \mathrm{C}$ & $22 \mathrm{C}$ & $22 \mathrm{C}$ & $22 \mathrm{D} 1$ \\
análise & 47 & 48 & 49 & 50 & 51 & 52 & 53 & 54 & 55 & 56 & 131 \\
\hline $\mathrm{SiO}_{2}$ & 62,94 & 59,86 & 63,03 & 63,8 & 63,06 & 56,64 & 63,24 & 62,08 & 62,79 & 61,99 & 62,95 \\
$\mathrm{Al}_{2} \mathrm{O}_{3}$ & 0,32 & 2,25 & 0,35 & 0,18 & 0,35 & 3,82 & 0,32 & 0,77 & 0,2 & 1,04 & 0,21 \\
$\mathrm{FeO}$ & 0,22 & 0,35 & 0,21 & 0,24 & 0,3 & 0,38 & 0,31 & 0,22 & 0,3 & 0,28 & 0,41 \\
$\mathrm{MnO}$ & 0 & 0,03 & 0,02 & 0,01 & 0 & 0,02 & 0 & 0,02 & 0 & 0,03 & 0 \\
$\mathrm{MgO}$ & 31,17 & 31,33 & 31,37 & 31,7 & 31,53 & 32,35 & 31,53 & 31,75 & 31,65 & 31,12 & 31,49 \\
$\mathrm{NiO}$ & 0,03 & 0,01 & 0 & 0,03 & 0,02 & 0 & 0,02 & 0 & 0,01 & 0 & 0 \\
$\mathrm{CaO}$ & 0,05 & 0,05 & 0,17 & 0,01 & 0,08 & 0,04 & 0,04 & 0,02 & 0,08 & 0,03 & 0,02 \\
$\mathrm{CoO}$ & 0 & 0 & 0 & 0 & 0 & 0 & 0 & 0 & 0 & 0 & 0 \\
$\mathrm{Total}$ & 94,73 & 93,88 & 95,15 & 95,97 & 95,34 & 93,25 & 95,46 & 94,86 & 95,03 & 94,49 & 95,08 \\
$\mathrm{Si}$ & 7,996 & 7,711 & 7,978 & 8,001 & 7,969 & 7,389 & 7,979 & 7,891 & 7,964 & 7,906 & 7,978 \\
$\mathrm{AlIV}$ & 0,004 & 0,289 & 0,022 & 0,000 & 0,031 & 0,587 & 0,021 & 0,109 & 0,030 & 0,094 & 0,022 \\
$\mathrm{Sum} \_\mathrm{T}$ & 8,000 & 8,000 & 8,000 & 8,001 & 8,000 & 7,976 & 8,000 & 8,000 & 7,994 & 8,000 & 8,000 \\
$\mathrm{AlVI}$ & 0,044 & 0,052 & 0,030 & 0,027 & 0,021 & 0,000 & 0,027 & 0,006 & 0,000 & 0,062 & 0,009 \\
$\mathrm{Fe} 2$ & 0,023 & 0,038 & 0,022 & 0,025 & 0,032 & 0,041 & 0,033 & 0,023 & 0,032 & 0,030 & 0,043 \\
$\mathrm{Mn}$ & 0,000 & 0,003 & 0,002 & 0,001 & 0,000 & 0,002 & 0,000 & 0,002 & 0,000 & 0,003 & 0,000 \\
$\mathrm{Mg}$ & 5,903 & 6,017 & 5,919 & 5,927 & 5,940 & 6,291 & 5,930 & 6,016 & 5,984 & 5,917 & 5,950 \\
$\mathrm{Ni}$ & 0,000 & 0,000 & 0,000 & 0,000 & 0,000 & 0,000 & 0,000 & 0,000 & 0,000 & 0,000 & 0,000 \\
$\mathrm{Ca}$ & 0,007 & 0,007 & 0,023 & 0,001 & 0,011 & 0,006 & 0,005 & 0,003 & 0,011 & 0,004 & 0,003 \\
$\mathrm{Co}$ & 0,000 & 0,000 & 0,000 & 0,000 & 0,000 & 0,000 & 0,000 & 0,000 & 0,000 & 0,000 & 0,000 \\
$\mathrm{Cations}$ & 13,977 & 14,117 & 13,996 & 13,982 & 14,004 & 14,316 & 13,995 & 14,050 & 14,021 & 14,016 & 14,005 \\
\hline & & & & & & & & & &
\end{tabular}


Anexo Tabela A-3. (continuação).

\begin{tabular}{|c|c|c|c|c|c|c|c|c|c|c|c|c|c|}
\hline \multirow{3}{*}{$\begin{array}{l}\text { litotipo } \\
\text { amostra } \\
\text { análise }\end{array}$} & \multicolumn{13}{|c|}{ (a) talco xisto } \\
\hline & 22D1 & 22D 1 & $22 \mathrm{D} 1$ & 22D1 & $22 \mathrm{D} 1$ & $22 \mathrm{Dl}$ & $22 \mathrm{D} 1$ & $22 \mathrm{Dl}$ & $22 \mathrm{D} 1$ & $22 \mathrm{D} 1$ & $22 \mathrm{D} 1$ & $22 \mathrm{D} 1$ & $22 \mathrm{D} 1$ \\
\hline & 132 & 133 & 134 & 135 & 136 & 137 & 138 & 139 & 140 & 141 & 142 & 144 & 145 \\
\hline $\mathrm{SiO}_{2}$ & 63,24 & 63,19 & 63,12 & 62,73 & 63,53 & 62,78 & 63,6 & 63,5 & 62,73 & 61,82 & 62,7 & 63.11 & 63,35 \\
\hline $\mathrm{Al}_{2} \mathrm{O}_{3}$ & 0,21 & 0,14 & 0,17 & 0,14 & 0,2 & 0,24 & 0,17 & 0,13 & 0,17 & 0,28 & 0,22 & 0,14 & 0,15 \\
\hline $\mathrm{FeO}$ & 0,36 & 0,38 & 0,39 & 0,38 & 0,42 & 0,36 & 0,38 & 0,36 & 0,3 & 0,39 & 0,37 & 0,36 & 0,41 \\
\hline $\mathrm{MnO}$ & 0 & 0,03 & 0 & 0 & 0,05 & 0,01 & 0 & 0,04 & 0,02 & 0 & 0 & 0,02 & 0 \\
\hline $\mathrm{MgO}$ & 31,22 & 31,3 & 31,38 & 31,37 & 31,34 & 31,31 & 31,38 & 31,61 & 31 & 30,57 & 31,12 & 31,34 & 31,28 \\
\hline $\mathrm{NiO}$ & 0,01 & 0 & 0 & 0 & 0,01 & 0,01 & 0,01 & 0,04 & 0,01 & 0 & 0 & 0 & 0 \\
\hline $\mathrm{CaO}$ & 0,01 & 0,03 & 0,05 & 0,21 & 0,02 & 0,17 & 0,05 & 0,04 & 0,03 & 1,01 & 0,03 & 0,04 & 0,04 \\
\hline $\mathrm{CoO}$ & 0 & 0 & 0 & 0 & 0 & 0 & 0 & 0 & 0 & 0 & 0 & 0 & 0 \\
\hline Total & 95,05 & 95,07 & 95,11 & 94,83 & 95,57 & 94,88 & 95,59 & 95,72 & 94,26 & 94,07 & 94,44 & 95,01 & 95,23 \\
\hline $\mathrm{Si}$ & 8,009 & 8,005 & 7,994 & 7,976 & 8,007 & 7,976 & 8,011 & 7,994 & 8,010 & 7,948 & 7,995 & 8,000 & 8,011 \\
\hline AlIV & 0,000 & 0,000 & 0,006 & 0,021 & 0,000 & 0,024 & 0,000 & 0,006 & 0,000 & 0,042 & 0,005 & 0,000 & 0,000 \\
\hline Sum_T & 8,009 & 8,005 & 8,000 & 7,997 & 8,007 & 8,000 & 8,011 & 8,000 & 8,010 & 7,990 & 8,000 & 8,000 & 8,011 \\
\hline AlVI & 0,031 & 0,021 & 0,019 & 0,000 & 0,030 & 0,012 & 0,025 & 0,013 & 0,026 & 0,000 & 0,028 & 0,021 & 0,022 \\
\hline $\mathrm{Fe} 2$ & 0,038 & 0,040 & 0,041 & 0,040 & 0,044 & 0,038 & 0,040 & 0,038 & 0,032 & 0,042 & 0,039 & 0,038 & 0,043 \\
\hline $\mathrm{Mn}$ & 0,000 & 0,003 & 0,000 & 0,000 & 0,005 & 0,001 & 0,000 & 0,004 & 0,002 & 0,000 & 0,000 & 0,002 & 0,000 \\
\hline $\mathrm{Mg}$ & 5,894 & 5,911 & 5,925 & 5,947 & 5,888 & 5,930 & 5,892 & 5,932 & 5,901 & 5,859 & 5,916 & 5,923 & 5,897 \\
\hline $\mathrm{Ni}$ & 0,000 & 0,000 & 0,000 & 0,000 & 0,000 & 0,000 & 0,000 & 0,000 & 0,000 & 0,000 & 0,000 & 0,000 & 0,000 \\
\hline $\mathrm{Ca}$ & 0,001 & 0,004 & 0,007 & 0,029 & 0,003 & 0,023 & 0,007 & 0,005 & 0,004 & 0,139 & 0,004 & 0,005 & 0,005 \\
\hline $\mathrm{Co}$ & 0,000 & 0,000 & 0,000 & 0,000 & 0,000 & 0,000 & 0,000 & 0,000 & 0,000 & 0,000 & 0,000 & 0,000 & 0,000 \\
\hline Cations & 13,973 & 13,984 & 13,992 & 14,013 & 13,977 & 14,004 & 13,975 & 13,992 & 13.975 & 14,030 & 13,987 & 13,989 & 13,978 \\
\hline
\end{tabular}


Anexo Tabela A-3. (continuação).

\begin{tabular}{|c|c|c|c|c|c|c|c|c|c|}
\hline \multirow{2}{*}{$\begin{array}{l}\text { litotipo } \\
\text { amostra }\end{array}$} & \multicolumn{6}{|c|}{ (b) talco maciço fino } & \multicolumn{3}{|c|}{ (c) talco em fraturas } \\
\hline & $42 \mathrm{~B}$ & $42 \mathrm{~B}$ & $42 \mathrm{~B}$ & $42 \mathrm{~B}$ & $42 \mathrm{~B}$ & $42 \mathrm{~B}$ & $06 \mathrm{~B}$ & $06 \mathrm{~B}$ & $\mathrm{O} 6 \mathrm{~B}$ \\
\hline análise & 672 & 673 & 674 & 675 & 676 & 677 & 234 & 235 & 236 \\
\hline $\mathrm{SiO}_{2}$ & 61,24 & 61,53 & 61,16 & 60,97 & 61,85 & 60,18 & 62,64 & 62,81 & 62,61 \\
\hline $\mathrm{Al}_{2} \mathrm{O}_{3}$ & 0,64 & 0,41 & 0,55 & 0,66 & 0,38 & 1,09 & 0,27 & 0,26 & 0,25 \\
\hline $\mathrm{FeO}$ & 0,2 & 0,14 & 0,2 & 0,13 & 0,15 & 0,12 & 0,1 & 0,08 & 0,14 \\
\hline $\mathrm{MnO}$ & 0 & 0,02 & 0 & 0 & 0 & 0,01 & 0 & 0,01 & 0 \\
\hline $\mathrm{MgO}$ & 30,42 & 31,08 & 30,94 & 30,78 & 30,98 & 30,66 & 31,4 & 31,08 & 31,27 \\
\hline $\mathrm{NiO}$ & 0,02 & 0,02 & 0 & 0,03 & 0 & 0,03 & 0,02 & 0 & 0 \\
\hline $\mathrm{CaO}$ & 0,09 & 0,1 & 0,66 & 0,11 & 0,36 & 0,11 & 0,11 & 0,1 & 0,14 \\
\hline $\mathrm{CoO}$ & 0 & 0 & 0 & 0 & 0 & 0 & 0 & 0 & 0 \\
\hline Total & 92,61 & 93,3 & 93,51 & 92,68 & 93,72 & 92,2 & 94,54 & 94,34 & 94,41 \\
\hline $\mathrm{Si}$ & 7,961 & 7,945 & 7,901 & 7,925 & 7,954 & 7,869 & 7,976 & 8,006 & 7,983 \\
\hline AlIV & 0,039 & 0,055 & 0,084 & 0,075 & 0,046 & 0,131 & 0,024 & 0,000 & 0,017 \\
\hline Sum_T & 8,000 & 8,000 & 7,985 & 8,000 & 8,000 & 8,000 & 8,000 & 8,006 & 8,000 \\
\hline AlVI & 0,059 & 0,007 & 0,000 & 0,026 & 0,012 & 0,037 & 0,016 & 0,039 & 0,021 \\
\hline $\mathrm{Fe} 2$ & 0,022 & 0,015 & 0,022 & 0,014 & 0,016 & 0,013 & 0,011 & 0,009 & 0,015 \\
\hline $\mathrm{Mn}$ & 0,000 & 0,002 & 0,000 & 0,000 & 0,000 & 0,001 & 0,000 & 0,001 & 0,000 \\
\hline $\mathrm{Mg}$ & 5,895 & 5,983 & 5,959 & 5,965 & 5,939 & 5,977 & 5,960 & 5,906 & 5,944 \\
\hline $\mathrm{Ni}$ & 0,000 & 0,000 & 0,000 & 0,000 & 0,000 & 0,000 & 0,000 & 0,000 & 0,000 \\
\hline $\mathrm{Ca}$ & 0,013 & 0,014 & 0,091 & 0,015 & 0,050 & 0,015 & 0,015 & 0,014 & 0,019 \\
\hline $\mathrm{Co}$ & 0,000 & 0,000 & 0,000 & 0,000 & 0,000 & 0,000 & 0,000 & 0,000 & 0,000 \\
\hline Cations & 13,989 & 14,021 & 14,057 & 14.020 & 14,017 & 14,043 & 14,002 & 13,975 & 13,999 \\
\hline
\end{tabular}


Anexo Tabela A-3. (continuaçāo).

\begin{tabular}{|c|c|c|c|c|c|c|c|c|c|c|c|c|c|}
\hline \multirow{3}{*}{$\begin{array}{l}\text { litotipo } \\
\text { amostra } \\
\text { análise }\end{array}$} & \multicolumn{13}{|c|}{ (c) talco em fraturas } \\
\hline & $06 \mathrm{~B}$ & $06 \mathrm{~B}$ & $06 \mathrm{~B}$ & $06 \mathrm{~B}$ & $06 \mathrm{~B}$ & $06 \mathrm{~B}$ & $06 \mathrm{~B}$ & $06 \mathrm{~B}$ & $06 \mathrm{~B}$ & $06 \mathrm{~B}$ & O6B & $06 \mathrm{~B}$ & $06 \mathrm{~B}$ \\
\hline & 237 & 238 & 239 & 240 & 241 & 242 & 243 & 244 & 245 & 246 & 247 & 248 & 249 \\
\hline $\mathrm{SiO}_{2}$ & 62,04 & 62.37 & 62,62 & 62,27 & 61,49 & 61,72 & 62,54 & 63,04 & 62,31 & 62,25 & 61,75 & 62.58 & 62,22 \\
\hline $\mathrm{Al}_{2} \mathrm{O}_{3}$ & 0,33 & 0,26 & 0,21 & 0,24 & 0,3 & 0,24 & 0,24 & 0,23 & 0,28 & 0,23 & 0,28 & 0,27 & 0,26 \\
\hline $\mathrm{FeO}$ & 0,13 & 0,1 & 0,17 & 0,12 & 0,09 & 0,07 & 0,14 & 0,16 & 0,16 & 0,12 & 0,18 & 0,12 & 0,11 \\
\hline $\mathrm{MnO}$ & 0,02 & 0,02 & 0,03 & 0 & 0 & 0 & 0 & 0,02 & 0 & 0 & 0 & 0 & 0 \\
\hline $\mathrm{MgO}$ & 31,14 & 31,24 & 31,82 & 31,17 & 30,6 & 30,82 & 30,9 & 29,99 & 30,8 & 30,73 & 30,3 & 30,29 & 30,52 \\
\hline $\mathrm{NiO}$ & 0,03 & 0,02 & 0 & 0 & 0 & 0 & 0,01 & 0 & 0 & 0 & 0 & 0 & 0 \\
\hline $\mathrm{CaO}$ & 0,18 & 0,13 & 0,33 & 0,11 & 0,11 & 0,08 & 0,05 & 0,1 & 0,09 & 0,11 & 0,07 & 0,17 & 0,1 \\
\hline $\mathrm{CoO}$ & 0 & 0 & 0 & 0 & 0 & 0 & 0 & 0 & 0 & 0 & 0 & 0 & 0 \\
\hline Total & 93,87 & 94,14 & 95,18 & 93,91 & 92,59 & 92,93 & 93,88 & 93,54 & 93,64 & 93,44 & 92,58 & 93,43 & 93,21 \\
\hline $\mathrm{Si}$ & 7,962 & 7,976 & 7,937 & 7,981 & 7,989 & 7,989 & 8,011 & 8,089 & 8,004 & 8,012 & 8,020 & 8,048 & 8,024 \\
\hline AllV & 0,038 & 0,024 & 0,031 & 0,019 & 0,011 & 0,011 & 0,000 & 0,000 & 0,000 & 0,000 & 0,000 & 0,000 & 0,000 \\
\hline Sum_T & 8,000 & 8,000 & 7,968 & 8,000 & 8,000 & 8,000 & 8,011 & 8,089 & 8,004 & 8,012 & 8,020 & 8,048 & 8,024 \\
\hline AlVI & 0,012 & 0,015 & 0,000 & 0,017 & 0,035 & 0,026 & 0,036 & 0,035 & 0,042 & 0,035 & 0,043 & 0,041 & 0,039 \\
\hline $\mathrm{Fe} 2$ & 0,014 & 0,011 & 0,018 & 0,013 & 0,010 & 0,008 & 0,015 & 0,017 & 0,017 & 0,013 & 0,020 & 0,013 & 0,012 \\
\hline $\mathrm{Mn}$ & 0,002 & 0,002 & 0,003 & 0,000 & 0,000 & 0,000 & 0,000 & 0,002 & 0,000 & 0,000 & 0,000 & 0,000 & 0,000 \\
\hline $\mathrm{Mg}$ & 5,958 & 5,956 & 6,013 & 5,956 & 5,927 & 5,947 & 5,901 & 5,737 & 5,898 & 5,896 & 5,867 & 5,807 & 5,867 \\
\hline $\mathrm{Ni}$ & 0,000 & 0,000 & 0,000 & 0,000 & 0,000 & 0,000 & 0,000 & 0,000 & 0,000 & 0,000 & 0,000 & 0,000 & 0,000 \\
\hline $\mathrm{Ca}$ & 0,025 & 0,018 & 0,045 & 0,015 & 0,015 & 0,011 & 0,007 & 0,014 & 0,012 & 0,015 & 0,010 & 0,023 & 0,014 \\
\hline Co & 0,000 & 0,000 & 0,000 & 0,000 & 0,000 & 0,000 & 0,000 & 0,000 & 0,000 & 0,000 & 0,000 & 0,000 & 0,000 \\
\hline Cations & 14,011 & 14,002 & 14,047 & 14,001 & 13,987 & 13,992 & 13,970 & 13,894 & 13,973 & 13,971 & 13,960 & 13,932 & 13,956 \\
\hline
\end{tabular}


Anexo Tabela A-4. Análises químicas de clorita em talco xisto do Grupo Itaiacoca (proporção catiônica recalculada para 26 átomos de oxigênio por fórmula unitária).

\begin{tabular}{|c|c|c|c|c|c|c|c|c|c|c|c|c|c|}
\hline $\begin{array}{l}\text { amostra } \\
\text { análise }\end{array}$ & $\begin{array}{c}02 \mathrm{AF} \\
57\end{array}$ & $\begin{array}{c}02 \mathrm{AF} \\
58\end{array}$ & $\begin{array}{c}02 \mathrm{AF} \\
59\end{array}$ & $\begin{array}{c}02 \mathrm{AF} \\
60\end{array}$ & $\begin{array}{c}\text { 02AF } \\
63\end{array}$ & $\begin{array}{c}02 \mathrm{AF} \\
62\end{array}$ & $\begin{array}{c}02 \mathrm{AF} \\
63\end{array}$ & $\begin{array}{c}\text { 02AF } \\
65\end{array}$ & $\begin{array}{c}02 \mathrm{AF} \\
66\end{array}$ & $\begin{array}{c}02 \mathrm{AF} \\
67\end{array}$ & $\begin{array}{c}02 \mathrm{AF} \\
68\end{array}$ & $\begin{array}{c}02 \mathrm{AF} \\
69\end{array}$ & $\begin{array}{c}02 \mathrm{AF} \\
70\end{array}$ \\
\hline $\mathrm{SiO}_{2}$ & 47,59 & 47,13 & 47,15 & 48,24 & 47,26 & 46,78 & 45,73 & 47,06 & 47,61 & 46,96 & 46,81 & 47,33 & 47,26 \\
\hline $\mathrm{TiO}_{2}$ & 0 & 0,07 & 0 & 0 & 0,02 & 0 & 0 & 0 & 0,02 & 0 & 0 & 0 & 0 \\
\hline $\mathrm{Al}_{2} \mathrm{O}_{3}$ & 0,43 & 0,32 & 0,37 & 0,43 & 0,3 & 0,27 & 0,39 & 0,18 & 0,39 & 0,17 & 0,24 & 0,31 & 0,32 \\
\hline $\mathrm{FeO}$ & 0,12 & 0,1 & 0,06 & 0,1 & 0,13 & 0,12 & 0,09 & 0,12 & 0,17 & 0,12 & 0,14 & 0,1 & 0,09 \\
\hline $\mathrm{MnO}$ & 0,02 & 0,04 & 0,02 & 0,04 & 0,03 & 0,02 & 0,03 & 0,03 & 0,03 & 0,04 & 0,01 & 0 & 0,02 \\
\hline $\mathrm{MgO}$ & 40,02 & 37,77 & 39,38 & 38,49 & 39,55 & 38,07 & 37,71 & 39,36 & 37,78 & 38,68 & 38,8 & 40,5 & 39,89 \\
\hline $\mathrm{CaO}$ & 0,21 & 0,2 & 0,19 & 0,19 & 0,23 & 0,22 & 0,16 & 0,17 & 0,26 & 0,18 & 0,17 & 0,14 & 0,17 \\
\hline $\mathrm{Na}_{2} \mathrm{O}$ & 0,03 & 0,03 & 0.03 & 0,02 & 0,02 & 0,02 & 0,02 & 0,01 & 0 & 0,01 & 0,02 & 0,02 & 0,04 \\
\hline $\mathrm{K}_{2} \mathrm{O}$ & 0 & 0 & 0 & 0 & 0 & 0,01 & 0,01 & 0,01 & 0,01 & 0 & 0 & 0 & 0,01 \\
\hline $\mathrm{Cr}_{2} \mathrm{O}_{3}$ & 0 & 0 & 0,03 & 0 & 0 & 0 & 0 & 0 & 0 & 0 & 0 & 0,02 & 0,04 \\
\hline $\mathrm{NiO}$ & 0 & 0 & 0 & 0 & 0 & 0 & 0 & 0 & 0 & 0 & 0 & 0 & 0 \\
\hline Total & 88,42 & 85,66 & 87,23 & 87,51 & 87,54 & 85,51 & 84,14 & 86,94 & 86,27 & 86,16 & 86,19 & 88,42 & 87,84 \\
\hline $\mathrm{Si}$ & 7,933 & 8,083 & 7,961 & 8,094 & 7,956 & 8,046 & 7,998 & 7,974 & 8,106 & 8,021 & 7,996 & 7,895 & 7,932 \\
\hline Allv & 0,067 & 0 & 0,039 & 0 & 0,044 & 0 & 0,002 & 0,026 & 0 & 0 & 0,004 & 0 & 0 \\
\hline Sum_T & 8 & 8,083 & 8 & 8,094 & 8 & 8,046 & 8 & 8 & 8,106 & 8,021 & 8 & 7,956 & 7,995 \\
\hline AIVI & 0,017 & 0,065 & 0,035 & 0,085 & 0,015 & 0,055 & 0,078 & 0,01 & 0,078 & 0,034 & 0,044 & 0 & 0 \\
\hline $\mathrm{Ti}$ & 0 & 0,009 & 0 & 0 & 0,003 & 0 & 0 & 0 & 0,003 & 0 & 0 & 0 & 0 \\
\hline $\mathrm{Fe} 2$ & 0,017 & 0,014 & 0,008 & 0,014 & 0,018 & 0,017 & 0,013 & 0,017 & 0,024 & 0,017 & 0,02 & 0,014 & 0,013 \\
\hline $\mathrm{Cr}$ & 0 & 0 & 0,004 & 0 & 0 & 0 & 0 & 0 & 0 & 0 & 0 & 0,003 & 0,005 \\
\hline Mn & 0,003 & 0,006 & 0,003 & 0,006 & 0,004 & 0,003 & 0,004 & 0,004 & 0,004 & 0,006 & 0,001 & 0 & 0,003 \\
\hline $\mathrm{Mg}$ & 9,945 & 9,657 & 9,912 & 9,627 & 9,926 & 9,761 & 9,832 & 9,943 & 9,589 & 9,849 & 9,88 & 10,072 & 9,98 \\
\hline $\mathrm{Ni}$ & 0 & 0 & 0 & 0 & 0 & 0 & 0 & 0 & 0 & 0 & 0 & 0 & 0 \\
\hline $\mathrm{Ca}$ & 0,038 & 0,037 & 0,034 & 0,034 & 0,041 & 0,041 & 0,03 & 0,031 & 0,047 & 0,033 & 0,031 & 0,025 & 0.031 \\
\hline $\mathrm{Na}$ & 0,01 & 0,01 & 0,01 & 0,007 & 0,007 & 0,007 & 0,007 & 0,003 & 0 & 0,003 & 0,007 & 0,006 & 0.013 \\
\hline K & 0 & 0 & 0 & 0 & 0 & 0,002 & 0,002 & 0,002 & 0,002 & 0 & 0 & 0 & 0,002 \\
\hline Cations & 18,03 & 17,881 & 18,006 & 17,867 & 18,014 & 17,932 & 17,966 & 18,01 & 17,853 & 17,963 & 17,983 & 18,076 & 18,042 \\
\hline
\end{tabular}


Anexo Tabela A-5. Análises químicas de serpentina em talco xisto do Grupo Itaiacoca (proporção catiônica recalculada para 26 átomos de oxigênio por fórmula unitária).

\begin{tabular}{lcccccccccccc}
\hline amostra & $22 \mathrm{~L}$ & $22 \mathrm{~L}$ & $22 \mathrm{~L}$ & $22 \mathrm{~L}$ & $22 \mathrm{~L}$ & $22 \mathrm{~L}$ & $22 \mathrm{~L}$ & $22 \mathrm{~L}$ & $22 \mathrm{~L}$ & $22 \mathrm{~L}$ & $22 \mathrm{~L}$ & $22 \mathrm{~L}$ \\
análise & 250 & 251 & 252 & 253 & 254 & 255 & 256 & 257 & 258 & 259 & 260 & 261 \\
\hline $\mathrm{SiO}_{2}$ & 45,45 & 45,04 & 45,5 & 45,15 & 44,2 & 44,19 & 45,78 & 44,37 & 45,02 & 44,51 & 44,08 & 45,19 \\
$\mathrm{Al}_{2} \mathrm{O}_{3}$ & 0,13 & 0,27 & 0,27 & 0,17 & 0,52 & 0,59 & 0,25 & 0,15 & 0,12 & 0,66 & 0,5 & 0,12 \\
$\mathrm{FeO}$ & 0,29 & 0,29 & 0,4 & 0,35 & 0,27 & 0,41 & 0,36 & 0,41 & 0,26 & 0,41 & 0,38 & 0,37 \\
$\mathrm{MnO}$ & 0 & 0 & 0 & 0,02 & 0 & 0 & 0,02 & 0 & 0,03 & 0 & 0 & 0,01 \\
$\mathrm{MgO}$ & 39,79 & 39,56 & 39,71 & 39,88 & 38,47 & 38,63 & 40,04 & 39,43 & 39,71 & 38,93 & 38,87 & 39,69 \\
$\mathrm{NiO}$ & 0 & 0,02 & 0 & 0 & 0 & 0,01 & 0,02 & 0 & 0,02 & 0,03 & 0,01 & 0,01 \\
$\mathrm{CaO}$ & 0,03 & 0,01 & 0,01 & 0,04 & 0,06 & 0,08 & 0,01 & 0,06 & 0,03 & 0,05 & 0,06 & 0,02 \\
$\mathrm{Total}$ & 85,69 & 85,19 & 85,89 & 85,61 & 83,52 & 83,91 & 86,48 & 84,42 & 85,19 & 84,59 & 83,9 & 85,41 \\
$\mathrm{Si}$ & 7,84 & 7,817 & 7,833 & 7,805 & 7,82 & 7,792 & 7,829 & 7,785 & 7,817 & 7,785 & 7,776 & 7,827 \\
$\mathrm{AlIV}$ & 0,026 & 0,055 & 0,055 & 0,035 & 0,108 & 0,123 & 0,05 & 0,031 & 0,025 & 0,136 & 0,104 & 0,024 \\
$\mathrm{Sum}-\mathrm{T}$ & 7,866 & 7,872 & 7,888 & 7,84 & 7,928 & 7,915 & 7,879 & 7,816 & 7,842 & 7,921 & 7,88 & 7,851 \\
$\mathrm{AIVI}$ & 0 & 0 & 0 & 0 & 0 & 0 & 0 & 0 & 0 & 0 & 0 & 0 \\
$\mathrm{Fe} 2$ & 0,042 & 0,042 & 0,058 & 0,051 & 0,04 & 0,06 & 0,051 & 0,06 & 0,038 & 0,06 & 0,056 & 0,054 \\
$\mathrm{Mn}$ & 0 & 0 & 0 & 0,003 & 0 & 0 & 0,003 & 0 & 0,004 & 0 & 0 & 0,001 \\
$\mathrm{Mg}$ & 10,232 & 10,236 & 10,192 & 10,277 & 10,146 & 10,155 & 10,208 & 10,313 & 10,279 & 10,151 & 10,223 & 10,249 \\
$\mathrm{Ni}$ & 0 & 0 & 0 & 0 & 0 & 0 & 0 & 0 & 0 & 0 & 0 \\
$\mathrm{Ca}$ & 0,006 & 0,002 & 0,002 & 0,007 & 0,011 & 0,015 & 0,002 & 0,011 & 0,006 & 0,009 & 0,011 & 0,004 \\
$\mathrm{Cations}$ & 18,146 & 18,152 & 18,14 & 18,178 & 18,125 & 18,145 & 18,143 & 18,2 & 18,169 & 18,141 & 18,17 & 18,159 \\
\hline
\end{tabular}


Anexo Tabela A-5. (continuação).

\begin{tabular}{lcccccc}
\hline amostra & $22 \mathrm{~L}$ & $22 \mathrm{~L}$ & $22 \mathrm{~L}$ & $22 \mathrm{~L}$ & $22 \mathrm{~L}$ & $22 \mathrm{~L}$ \\
análise & 262 & 263 & 264 & 265 & 266 & 267 \\
\hline $\mathrm{SiO}_{2}$ & 45,07 & 44,89 & 45,34 & 44,74 & 45,15 & 44,67 \\
$\mathrm{Al}_{2} \mathrm{O}_{3}$ & 0,15 & 0,29 & 0,16 & 0,24 & 0,3 & 0,27 \\
$\mathrm{FeO}$ & 0,37 & 0,37 & 0,29 & 0,32 & 0,28 & 0,31 \\
$\mathrm{MnO}$ & 0,02 & 0,03 & 0,02 & 0,01 & 0,01 & 0 \\
$\mathrm{MgO}$ & 39,61 & 39,24 & 39,51 & 39,21 & 39,05 & 39,96 \\
$\mathrm{NiO}$ & 0 & 0,01 & 0 & 0,01 & 0 & 0 \\
$\mathrm{CaO}$ & 0,01 & 0,04 & 0,03 & 0,03 & 0,08 & 0,02 \\
$\mathrm{Total}$ & 85,23 & 84,87 & 85,35 & 84,56 & 84,87 & 85,23 \\
$\mathrm{Si}$ & 7,823 & 7,824 & 7,851 & 7,824 & 7,859 & 7,76 \\
$\mathrm{AlIV}$ & 0,031 & 0,06 & 0,033 & 0,049 & 0,061 & 0,055 \\
$\mathrm{Sum} \_\mathrm{T}$ & 7,854 & 7,884 & 7,884 & 7,873 & 7,92 & 7,815 \\
$\mathrm{AlVI}$ & 0 & 0 & 0 & 0 & 0 & 0 \\
$\mathrm{Fe} 2$ & 0,054 & 0,054 & 0,042 & 0,047 & 0,041 & 0,045 \\
$\mathrm{Mn}$ & 0,003 & 0,004 & 0,003 & 0,001 & 0,001 & 0 \\
$\mathrm{Mg}$ & 10,249 & 10,196 & 10,199 & 10,222 & 10,133 & 10,348 \\
$\mathrm{Ni}$ & 0 & 0 & 0 & 0 & 0 & 0 \\
$\mathrm{Ca}$ & 0,002 & 0,007 & 0,006 & 0,006 & 0,015 & 0,004 \\
$\mathrm{Cations}$ & 18,162 & 18,145 & 18,134 & 18,149 & 18,11 & 18,212 \\
\hline
\end{tabular}


Anexo Tabela A-6. Análises químicas de tremolita do Grupo Itaiacoca (proporção catiônica recalculada para 23 átomos de oxigênio por fórmula unitária).

\begin{tabular}{|c|c|c|c|c|c|c|c|c|c|}
\hline \multirow{3}{*}{$\begin{array}{l}\text { litotipo } \\
\text { amostra } \\
\text { análise } \\
\end{array}$} & \multicolumn{9}{|c|}{ (a) talco xisto } \\
\hline & $22 \mathrm{~L}$ & $22 \mathrm{~L}$ & $22 \mathrm{~L}$ & $22 \mathrm{~L}$ & $22 \mathrm{~L}$ & $22 \mathrm{~L}$ & $22 \mathrm{~L}$ & $22 \mathrm{~L}$ & $22 \mathrm{~L}$ \\
\hline & 186 & 187 & 189 & 190 & 193 & 194 & 195 & 197 & 159 \\
\hline $\mathrm{SiO}_{2}$ & 58,74 & 58,67 & 58,91 & 58,58 & 58,31 & 58,69 & 59,39 & 60,05 & 59,08 \\
\hline $\mathrm{TiO}_{2}$ & 0,05 & 0,03 & 0,00 & 0,00 & 0,04 & 0,03 & 0,07 & 0 & 0,02 \\
\hline $\mathrm{Al}_{2} \mathrm{O}_{3}$ & 0,07 & 0,03 & 0,04 & 0,06 & 0,04 & 0,09 & 0,02 & 0 & 0,14 \\
\hline $\mathrm{FeO}$ & 0,17 & 0,09 & 0,16 & 0,17 & 0,11 & 0,11 & 0,13 & 0,14 & 0,22 \\
\hline $\mathrm{MnO}$ & 0,00 & 0,00 & 0,03 & 0,00 & 0,00 & 0,02 & 0,01 & 0 & 0,01 \\
\hline $\mathrm{MgO}$ & 24,90 & 24,82 & 24,93 & 25,24 & 24,86 & 25,08 & 24,98 & 24,95 & 24,76 \\
\hline $\mathrm{CaO}$ & 13,61 & 13,87 & 13,65 & 13,74 & 13,86 & 13,69 & 14,01 & 13,9 & 13,78 \\
\hline $\mathrm{Na}_{2} \mathrm{O}$ & 0,05 & 0,03 & 0,07 & 0,06 & 0,04 & 0,05 & 0,06 & 0,03 & 0 \\
\hline $\mathrm{K}_{2} \mathrm{O}$ & 0,03 & 0,03 & 0,03 & 0,03 & 0,02 & 0,04 & 0,02 & 0,01 & 0,02 \\
\hline $\mathrm{Cr}_{2} \mathrm{O}_{3}$ & 0 & 0 & 0 & 0 & 0 & 0 & 0 & 0 & 0 \\
\hline Total & 97,62 & 97,57 & 97,82 & 97,88 & 97,28 & 97,8 & 98,69 & 99,08 & 98,03 \\
\hline TSi & 7,966 & 7,965 & 7,974 & 7,933 & 7,945 & 7,949 & 7,971 & 8,014 & 7,978 \\
\hline TAl & 0,110 & 0,005 & 0,006 & 0,010 & 0,006 & 0,014 & 0,003 & 0,000 & 0,022 \\
\hline TFe3 & 0,000 & 0,000 & 0,000 & 0,000 & 0,000 & 0,000 & 0,000 & 0,000 & 0,000 \\
\hline $\mathrm{TTi}$ & 0,005 & 0,003 & 0,000 & 0,000 & 0,004 & 0,003 & 0,007 & 0,000 & 0,000 \\
\hline Sum_T & 7,983 & 7,973 & 7,980 & 7,943 & 7,955 & 7,966 & 7,982 & 8,014 & 8,000 \\
\hline CAI & 0,000 & 0,000 & 0,000 & 0,000 & 0,000 & 0,000 & 0,000 & 0,000 & 0,000 \\
\hline $\mathrm{CCr}$ & 0,000 & 0,000 & 0,000 & 0,000 & 0,000 & 0,000 & 0,000 & 0,000 & 0,000 \\
\hline $\mathrm{CFe} 3$ & 0,000 & 0,000 & 0,000 & 0,000 & 0,000 & 0,000 & 0,000 & 0,000 & 0,000 \\
\hline $\mathrm{CTi}$ & 0,000 & 0,000 & 0,000 & 0,000 & 0,000 & 0,000 & 0,000 & 0,000 & 0,002 \\
\hline $\mathrm{CMg}$ & 5,000 & 5,000 & 5,000 & 5,000 & 5,000 & 5,000 & 4,998 & 4,964 & 4,985 \\
\hline $\mathrm{CFe} 2$ & 0,000 & 0,000 & 0,000 & 0,000 & 0,000 & 0,000 & 0,002 & 0,016 & 0,013 \\
\hline $\mathrm{CMn}$ & 0,000 & 0,000 & 0,000 & 0,000 & 0,000 & 0,000 & 0,000 & 0,000 & 0,000 \\
\hline $\mathrm{CCa}$ & 0,000 & 0,000 & 0,000 & 0,000 & 0,000 & 0,000 & 0,000 & 0,020 & 0,000 \\
\hline Sum_C & 5,000 & 5,000 & 5,000 & 5,000 & 5,000 & 5,000 & 5,000 & 5,000 & 5,000 \\
\hline $\mathrm{BMg}$ & 0,340 & 0,230 & 0,300 & 0,096 & 0,050 & 0,064 & 0,000 & 0,000 & 0,000 \\
\hline $\mathrm{BFe} 2$ & 0,019 & 0,010 & 0,018 & 0,019 & 0,013 & 0,012 & 0,013 & 0,000 & 0,012 \\
\hline $\mathrm{BMn}$ & 0,000 & 0,000 & 0,003 & 0,000 & 0,000 & 0,002 & 0,001 & 0,000 & 0,001 \\
\hline $\mathrm{BCa}$ & 1,946 & 1,967 & 1,948 & 1,885 & 1,938 & 1,922 & 1,986 & 1,967 & 1,987 \\
\hline $\mathrm{BNa}$ & 0,000 & 0,000 & 0,000 & 0,000 & 0,000 & 0,000 & 0,000 & 0,008 & 0,000 \\
\hline Sum_B & 2,000 & 2,000 & 2,000 & 2,000 & 2,000 & 2,000 & 2,000 & 1,975 & 2,000 \\
\hline $\mathrm{ACa}$ & 0,310 & 0,051 & 0,031 & 0,109 & 0,085 & 0,065 & 0,029 & 0,000 & 0,007 \\
\hline $\mathrm{ANa}$ & 0,130 & 0,008 & 0,018 & 0,016 & 0,011 & 0,013 & 0,016 & 0,000 & 0,000 \\
\hline AK & 0,005 & 0,005 & 0,005 & 0,005 & 0,003 & 0,007 & 0,003 & 0,002 & 0,003 \\
\hline Sum_A & 0,050 & 0,640 & 0,055 & 0,130 & 0,099 & 0,085 & 0,048 & 0,002 & 0,010 \\
\hline Sum_cat & 15,032 & 15,036 & 15,035 & 15,072 & 15,055 & 15,051 & 15,029 & 14,991 & 15,010 \\
\hline
\end{tabular}


Anexo Tabela A-6. (continuação).

\begin{tabular}{|c|c|c|c|c|c|c|c|c|c|}
\hline \multirow{3}{*}{$\begin{array}{l}\text { litotipo } \\
\text { amostra } \\
\text { análise } \\
\end{array}$} & \multicolumn{9}{|c|}{ (b) mármore dolomítico no contato com granito } \\
\hline & $07 \mathrm{~F}$ & $07 \mathrm{~F}$ & $07 \mathrm{~F}$ & $07 \mathrm{~F}$ & $07 \mathrm{~F}$ & $07 \mathrm{~F}$ & $07 \mathrm{~F}$ & $07 \mathrm{~F}$ & $07 \mathrm{~F}$ \\
\hline & 160 & 161 & 162 & 163 & 164 & 165 & 166 & 167 & 168 \\
\hline $\mathrm{SiO}_{2}$ & 58,87 & 58,56 & 58,56 & 58,87 & 58,67 & 58,32 & 58,45 & 58,87 & 58,1 \\
\hline $\mathrm{TiO}_{2}$ & 0 & 0,09 & 0,01 & 0 & 0 & 0,02 & 0 & 0 & 0,07 \\
\hline $\mathrm{Al}_{2} \mathrm{O}_{3}$ & 0,2 & 0,44 & 0,35 & 0,28 & 0,17 & 0,14 & 0,19 & 0,21 & 0,19 \\
\hline $\mathrm{FeO}$ & 0,16 & 0,22 & 0,22 & 0,19 & 0,19 & 0,21 & 0,2 & 0,21 & 0,17 \\
\hline $\mathrm{MnO}$ & 0,02 & 0 & 0 & 0,04 & 0,01 & 0 & 0 & 0 & 0 \\
\hline $\mathrm{MgO}$ & 24,74 & 24,49 & 24,66 & 24,68 & 24,69 & 23,82 & 24,7 & 24,74 & 24,68 \\
\hline $\mathrm{CaO}$ & 13,85 & 13,9 & 13,84 & 13,86 & 13,99 & 13,76 & 13,77 & 13,8 & 13,73 \\
\hline $\mathrm{Na}_{2} \mathrm{O}$ & 0,03 & 0,05 & 0,05 & 0,05 & 0,04 & 0,04 & 0,02 & 0,04 & 0,04 \\
\hline $\mathrm{K}_{2} \mathrm{O}$ & 0,04 & 0,03 & 0,02 & 0,03 & 0,01 & 0 & 0,01 & 0,03 & 0,03 \\
\hline $\mathrm{Cr}_{2} \mathrm{O}_{3}$ & 0 & 0 & 0 & 0 & 0 & 0 & 0 & 0 & 0 \\
\hline Total & 97,91 & 97,78 & 97,71 & 98,00 & 97,77 & 96,31 & 97,34 & 97,90 & 97,01 \\
\hline $\mathrm{TS} i$ & 7,964 & 7,937 & 7,942 & 7,958 & 7,954 & 8,014 & 7,955 & 7,964 & 7,938 \\
\hline TAl & 0,032 & 0,063 & 0,056 & 0,042 & 0,027 & 0,000 & 0,030 & 0,033 & 0,031 \\
\hline TFe3 & 0,000 & 0,000 & 0,000 & 0,000 & 0,000 & 0,000 & 0,000 & 0,000 & 0,000 \\
\hline $\mathrm{TT} \mathbf{i}$ & 0,000 & 0,000 & 0,001 & 0,000 & 0,000 & 0,000 & 0,000 & 0,000 & 0,007 \\
\hline Sum $_{-} T$ & 7,996 & 8,000 & 7,999 & 8,000 & 7,981 & 8,014 & 7,985 & 7,998 & 7,976 \\
\hline $\mathrm{CAl}$ & 0,000 & 0,008 & 0,000 & 0,003 & 0,000 & 0,023 & 0,000 & 0,000 & 0,000 \\
\hline $\mathrm{CCr}$ & 0,000 & 0,000 & 0,000 & 0,000 & 0,000 & 0,000 & 0,000 & 0,000 & 0,000 \\
\hline $\mathrm{CFe} 3$ & 0,000 & 0,000 & 0,000 & 0,000 & 0,000 & 0,000 & 0,000 & 0,000 & 0,000 \\
\hline $\mathrm{CTi}$ & 0,000 & 0,009 & 0,000 & 0,000 & 0,000 & 0,002 & 0,000 & 0,000 & 0,000 \\
\hline $\mathrm{CMg}$ & 4,989 & 4,949 & 4,986 & 4,974 & 4,990 & 4,879 & 5,000 & 4,990 & 5,000 \\
\hline $\mathrm{CFe} 2$ & 0,011 & 0,025 & 0,014 & 0,021 & 0,010 & 0,024 & 0,000 & 0,010 & 0,000 \\
\hline CMn & 0,000 & 0,000 & 0,000 & 0,002 & 0,000 & 0,000 & 0,000 & 0,000 & 0,000 \\
\hline $\mathrm{CCa}$ & 0,000 & 0,010 & 0,000 & 0,000 & 0,000 & 0,072 & 0,000 & 0,000 & 0,000 \\
\hline Sum_C & 5,000 & 5,000 & 5,000 & 5,000 & 5,000 & 5,000 & 5,000 & 5,000 & 5,000 \\
\hline $\mathrm{BMg}$ & 0,000 & 0,000 & 0,000 & 0,000 & 0,000 & 0,000 & 0,011 & 0,000 & 0,027 \\
\hline $\mathrm{BFe} 2$ & 0,007 & 0,000 & 0,011 & 0,000 & 0,012 & 0,000 & 0,023 & 0,013 & 0,019 \\
\hline BMn & 0,002 & 0,000 & 0,000 & 0,003 & 0,001 & 0,000 & 0,000 & 0,000 & 0,000 \\
\hline $\mathrm{BCa}$ & 1,990 & 2,000 & 1,989 & 1,997 & 1,987 & 1,954 & 1,966 & 1,987 & 1,954 \\
\hline $\mathrm{BNa}$ & 0,000 & 0,000 & 0,000 & 0,000 & 0,000 & 0,011 & 0,000 & 0,000 & 0,000 \\
\hline Sum_B & 2,000 & 2,000 & 2,000 & 2,000 & 2,000 & 1,965 & 2,000 & 2,000 & 2,000 \\
\hline $\mathrm{ACa}$ & 0,017 & 0,009 & 0,022 & 0,010 & 0,045 & 0,000 & 0,042 & 0,014 & 0,056 \\
\hline $\mathrm{ANa}$ & 0,008 & 0,013 & 0,013 & 0,013 & 0,011 & 0,000 & 0,005 & 0,010 & 0,011 \\
\hline $\mathrm{AK}$ & 0,007 & 0,005 & 0,003 & 0,005 & 0,002 & 0,000 & 0,002 & 0,005 & 0,005 \\
\hline Sum_A & 0,032 & 0,027 & 0,038 & 0,028 & 0,057 & 0,000 & 0,049 & 0,029 & 0,072 \\
\hline Sum_cat & 15,028 & 15,027 & 15,037 & 15,028 & 15,038 & 14,978 & 15,034 & 15,027 & 15,047 \\
\hline
\end{tabular}


Anexo Tabela A-6. (continuação).

\begin{tabular}{|c|c|c|c|c|c|c|c|c|c|}
\hline \multirow{3}{*}{$\begin{array}{l}\text { litotipo } \\
\text { amostra } \\
\text { análise }\end{array}$} & \multicolumn{9}{|c|}{ (b) mármore dolomítico no contato com granito } \\
\hline & $07 \mathrm{~F}$ & $07 \mathrm{~F}$ & $07 \mathrm{~F}$ & $07 \mathrm{~F}$ & $07 \mathrm{~F}$ & $07 \mathrm{~F}$ & $07 \mathrm{~F}$ & $07 \mathrm{~F}$ & $07 \mathrm{~F}$ \\
\hline & 169 & 170 & 171 & 172 & 173 & 174 & 175 & 176 & 177 \\
\hline $\mathrm{SiO}_{2}$ & 58,64 & 58,1 & 58,01 & 58,46 & 58,14 & 58,21 & 58,4 & 57,43 & 57,37 \\
\hline $\mathrm{TiO}_{2}$ & 0,01 & 0,05 & 0,08 & 0 & 0,03 & 0 & 0 & 0,07 & 0 \\
\hline $\mathrm{Al}_{2} \mathrm{O}_{3}$ & 0,02 & 0,31 & 0,37 & 0,27 & 0,61 & 0,39 & 0,42 & 1,59 & 1,55 \\
\hline $\mathrm{FeO}$ & 0,15 & 0,21 & 0,16 & 0,19 & 0,17 & 0,23 & 0,2 & 0,22 & 0,17 \\
\hline $\mathrm{MnO}$ & 0,01 & 0 & 0 & 0,01 & 0,04 & 0 & 0 & 0 & 0,03 \\
\hline $\mathrm{MgO}$ & 24,84 & 24,71 & 24,61 & 24,61 & 24,59 & 24,56 & 24,46 & 24,28 & 24,29 \\
\hline $\mathrm{CaO}$ & 13,95 & 13,86 & 13,8 & 13,73 & 13,82 & 13,65 & 13,68 & 13,8 & 13,91 \\
\hline $\mathrm{Na}_{2} \mathrm{O}$ & 0,01 & 0,05 & 0,06 & 0,05 & 0,06 & 0,05 & 0,04 & 0,1 & 0,1 \\
\hline $\mathrm{K}_{2} \mathrm{O}$ & 0 & 0,02 & 0,04 & 0,05 & 0,01 & 0,03 & 0,03 & 0,03 & 0,03 \\
\hline $\mathrm{Cr}_{2} \mathrm{O}_{3}$ & 0 & 0 & 0 & 0 & 0 & 0 & 0 & 0 & 0 \\
\hline Total & 97,63 & 97,31 & 97,13 & 97,37 & 97,47 & 97,12 & 97,23 & 97,52 & 97,45 \\
\hline $\mathrm{TSi}$ & 7,959 & 7,919 & 7,919 & 7,954 & 7,907 & 7,940 & 7,953 & 7,813 & 7,813 \\
\hline $\mathrm{TAl}$ & 0,003 & 0,050 & 0,059 & 0,043 & 0,093 & 0,060 & 0,047 & 0,187 & 0,187 \\
\hline TFe3 & 0,000 & 0,000 & 0,000 & 0,000 & 0,000 & 0,000 & 0,000 & 0,000 & 0,000 \\
\hline $\mathrm{TTi}$ & 0,001 & 0,005 & 0,008 & 0,000 & 0,000 & 0,000 & 0,000 & 0,000 & 0,000 \\
\hline Sum_T & 7,964 & 7,974 & 7,987 & 7,997 & 8,000 & 8,000 & 8,000 & 8,000 & 8,000 \\
\hline $\mathrm{CAI}$ & 0,000 & 0,000 & 0,000 & 0,000 & 0,005 & 0,003 & 0,021 & 0,068 & 0,062 \\
\hline $\mathrm{CCr}$ & 0,000 & 0,000 & 0,000 & 0,000 & 0,000 & 0,000 & 0,000 & 0,000 & 0,000 \\
\hline $\mathrm{CFe} 3$ & 0,000 & 0,000 & 0,000 & 0,000 & 0,000 & 0,000 & 0,000 & 0,000 & 0,000 \\
\hline CTi & 0,000 & 0,000 & 0,000 & 0,000 & 0,003 & 0,000 & 0,000 & 0,007 & 0,000 \\
\hline $\mathrm{CMg}$ & 5,000 & 5,000 & 5,000 & 4,992 & 4,986 & 4,994 & 4,966 & 4,924 & 4,932 \\
\hline $\mathrm{CFe} 2$ & 0,000 & 0,000 & 0,000 & 0,008 & 0,006 & 0,002 & 0,014 & 0,001 & 0,006 \\
\hline $\mathrm{CMn}$ & 0,000 & 0,000 & 0,000 & 0,000 & 0,000 & 0,000 & 0,000 & 0,000 & 0,000 \\
\hline $\mathrm{CCa}$ & 0,000 & 0,000 & 0,000 & 0,000 & 0,000 & 0,000 & 0,000 & 0,000 & 0,000 \\
\hline Sum_C & 5,000 & 5,000 & 5,000 & 5,000 & 5,000 & 5,000 & 5,000 & 5,000 & 5,000 \\
\hline $\mathrm{BMg}$ & 0,026 & 0,021 & 0,008 & 0,000 & 0,000 & 0,000 & 0,000 & 0,000 & 0,000 \\
\hline $\mathrm{BFe} 2$ & 0,017 & 0,024 & 0,018 & 0,013 & 0,013 & 0,024 & 0,009 & 0,025 & 0,013 \\
\hline BMn & 0,001 & 0,000 & 0,000 & 0,001 & 0,005 & 0,000 & 0,000 & 0,000 & 0,003 \\
\hline $\mathrm{BCa}$ & 1,956 & 1,955 & 1,973 & 1,985 & 1,982 & 1,976 & 1,991 & 1,975 & 1,984 \\
\hline $\mathrm{BNa}$ & 0,000 & 0,000 & 0,000 & 0,000 & 0,000 & 0,000 & 0,000 & 0,000 & 0,000 \\
\hline Sum_B & 2,000 & 2,000 & 2,000 & 2,000 & 2,000 & 2,000 & 2,000 & 2,000 & 2,000 \\
\hline $\mathrm{ACa}$ & 0,073 & 0,069 & 0,045 & 0,016 & 0,032 & 0,019 & 0,005 & 0,036 & 0,046 \\
\hline $\mathrm{ANa}$ & 0,003 & 0,013 & 0,016 & 0,013 & 0,016 & 0,013 & 0,011 & 0,026 & 0,026 \\
\hline $\mathrm{AK}$ & 0,000 & 0,003 & 0,007 & 0,009 & 0,002 & 0,005 & 0,005 & 0,005 & 0,005 \\
\hline Sum_A & 0,076 & 0,085 & 0,068 & 0,038 & 0,049 & 0,037 & 0,021 & 0,068 & 0,078 \\
\hline Sum_cat & 15,039 & 15,059 & 15,054 & 15,035 & 15,049 & 15,037 & 15,021 & 15,068 & 15,078 \\
\hline
\end{tabular}


Anexo Tabela A-6. (continuação).

\begin{tabular}{|c|c|c|c|}
\hline \multirow{3}{*}{$\begin{array}{l}\text { litotipo } \\
\text { amostra } \\
\text { análise }\end{array}$} & \multicolumn{3}{|c|}{ (b) mármore dol. ctato com granito } \\
\hline & $07 \mathrm{~F}$ & $07 \mathrm{~F}$ & $07 \mathrm{~F}$ \\
\hline & 178 & 179 & 180 \\
\hline $\mathrm{SiO}_{2}$ & 58,67 & 58,2 & 58,55 \\
\hline $\mathrm{TiO}_{2}$ & 0 & 0 & 0,02 \\
\hline $\mathrm{Al}_{2} \mathrm{O}_{3}$ & 0,07 & 0,2 & 0,15 \\
\hline $\mathrm{FeO}$ & 0,14 & 0,24 & 0,21 \\
\hline $\mathrm{MnO}$ & 0,02 & 0,04 & 0,01 \\
\hline $\mathrm{MgO}$ & 24,89 & 24,69 & 24,87 \\
\hline $\mathrm{CaO}$ & 13,89 & 13,88 & 13,78 \\
\hline $\mathrm{Na}_{2} \mathrm{O}$ & 0 & 0,04 & 0,03 \\
\hline $\mathrm{K}_{2} \mathrm{O}$ & 0,02 & 0 & 0,03 \\
\hline $\mathrm{Cr}_{2} \mathrm{O}_{3}$ & 0 & 0 & 0 \\
\hline Total & 97,70 & 97,29 & 97,65 \\
\hline TSi & 7,957 & 7,935 & 7,946 \\
\hline TAl & 0,011 & 0,032 & 0,024 \\
\hline TFe3 & 0,000 & 0,000 & 0,000 \\
\hline TTi & 0,000 & 0,000 & 0,002 \\
\hline Sum_T & 7,968 & 7,967 & 7,972 \\
\hline CAl & 0,000 & 0,000 & 0,000 \\
\hline $\mathrm{CCr}$ & 0,000 & 0,000 & 0,000 \\
\hline $\mathrm{CFe} 3$ & 0,000 & 0,000 & 0,000 \\
\hline CTi & 0,000 & 0,000 & 0,000 \\
\hline $\mathrm{CMg}$ & 5,000 & 5,000 & 5,000 \\
\hline $\mathrm{CFe} 2$ & 0,000 & 0,000 & 0,000 \\
\hline $\mathrm{CMn}$ & 0,000 & 0,000 & 0,000 \\
\hline $\mathrm{CCa}$ & 0,000 & 0,000 & 0,000 \\
\hline Sum_C & 5,000 & 5,000 & 5,000 \\
\hline $\mathrm{BMg}$ & 0,032 & 0,018 & 0,032 \\
\hline $\mathrm{BFe} 2$ & 0,016 & 0,027 & 0,024 \\
\hline BMn & 0,002 & 0,005 & 0,001 \\
\hline $\mathrm{BCa}$ & 1,950 & 1,950 & 1,943 \\
\hline $\mathrm{BNa}$ & 0,000 & 0,000 & 0,000 \\
\hline $\operatorname{Sum}_{\text {B }} B$ & 2,000 & 2,000 & 2,000 \\
\hline $\mathrm{ACa}$ & 0,068 & 0,077 & 0,061 \\
\hline ANa & 0,000 & 0,011 & 0,008 \\
\hline AK & 0,003 & 0,000 & 0,005 \\
\hline Sum_A & 0,072 & 0,088 & 0,074 \\
\hline Sum_cat & 15,040 & 15,055 & 15,046 \\
\hline
\end{tabular}


Anexo Tabela A-7. Análises químicas de diopsídio de mármore dolomíticos em contato com o Granito Cunhaporanga (proporção catiônica recalculada para 4 átomos de oxigênios por fórmula unitária).

\begin{tabular}{|c|c|c|c|c|c|c|c|c|c|c|c|c|c|c|c|c|c|c|c|}
\hline $\begin{array}{l}\text { amostra } \\
\text { análise }\end{array}$ & $43 C$ & $43 C$ & $43 \mathrm{C}$ & $43 \mathrm{C}$ & $43 C$ & $43 C$ & $43 C$ & $43 \mathrm{C}$ & 05A2 & $05^{a} 2$ & $05 \mathrm{~A} 2$ & $05 \mathrm{~A} 2$ & $05 A 2$ & $05 \mathrm{~A} 2$ & 05A2 & $05 \mathrm{~A} 2$ & $05 \mathrm{~A} 2$ & $05 \mathrm{~A} 2$ & $05 \mathrm{~A} 2$ \\
\hline análise & 628 & 629 & 630 & 631 & 632 & 633 & 634 & 635 & 354 & 355 & 356 & 357 & 358 & 359 & 360 & 361 & 362 & 363 & 364 \\
\hline $\mathrm{SiO}_{2}$ & 54,46 & 54,79 & 54,92 & 54,75 & 54,85 & 54,96 & 54,37 & 55,21 & 55,77 & 55,76 & 55,55 & 55,52 & 55,38 & 55,49 & 55,43 & 55,56 & 55,67 & 55,28 & 55,55 \\
\hline $\mathrm{TiO}_{2}$ & 0 & 0 & 0,03 & 0,03 & 0 & 0,07 & 0 & 0,01 & 0 & 0,03 & 0,01 & 0 & 0,01 & 0 & 0,01 & 0 & 0 & 0,07 & 0 \\
\hline $\mathrm{Al}_{2} \mathrm{O}_{3}$ & 0,2 & $0,2 \mathrm{I}$ & 0,18 & 0,17 & 0,17 & 0,17 & 0,21 & 0,19 & 0,09 & 0,08 & 0,07 & 0,02 & 0 & 0,04 & 0,04 & 0,02 & 0,04 & 0,03 & 0,05 \\
\hline $\mathrm{FeO}$ & 0,5 & 0,45 & 0,5 & 0,59 & 0,46 & 0,55 & 0,44 & 0,39 & 0,18 & 0,07 & 0,1 & 0,12 & 0,075 & 0,08 & 0,11 & 0,17 & 0,14 & 0,09 & 0 \\
\hline $\mathrm{MnO}$ & 0,01 & 0,03 & 0,01 & 0,05 & 0 & 0,01 & 0,01 & 0,04 & 0,01 & 0,02 & 0 & 0,01 & 0 & 0 & 0,03 & 0,02 & 0,01 & 0,01 & 0 \\
\hline $\mathrm{MgO}$ & 18,45 & 18,57 & 18,36 & 18,52 & 18,43 & 18,56 & 18,55 & 18,5 & 18,58 & 18,54 & 18,61 & 18,76 & 18,86 & 18,67 & 18,73 & 18,72 & 18,66 & 18,52 & 18,57 \\
\hline $\mathrm{CaO}$ & 26,05 & 26,41 & 25,86 & 26,18 & 26,3 & 26,09 & 26,32 & 26,05 & 26,13 & 26,11 & 26,2 & 25,84 & 26,07 & 26,18 & 26,14 & 26,34 & 25,93 & 26,41 & 26,32 \\
\hline $\mathrm{Na}_{2} \mathrm{O}$ & 0,07 & 0,08 & 0,07 & 0,07 & 0,04 & 0,06 & 0,09 & 0,08 & 0,02 & 0,04 & 0,01 & 0,02 & 0 & 0 & 0,01 & 0,02 & 0 & 0 & 0 \\
\hline $\mathrm{K}_{2} \mathrm{O}$ & 0 & 0 & 0 & 0,01 & 0 & 0 & 0,02 & 0,01 & 0 & 0 & 0,01 & 0 & 0 & 0 & 0 & 0 & 0 & 0 & 0,01 \\
\hline $\mathrm{Cr}_{2} \mathrm{O}_{3}$ & 0 & 0 & 0 & 0 & 0 & 0 & 0 & 0 & 0 & 0 & 0,04 & 0 & 0,01 & 0,003 & 0,05 & 0 & 0,01 & 0,03 & 0 \\
\hline $\mathrm{Fe}_{2} \mathrm{O}_{3}$ & 0 & 0 & 0 & 0 & 0 & 0 & 0 & 0 & 0 & 0 & 0 & 0 & 0 & 0 & 0 & 0 & 0 & 0 & 0 \\
\hline $\mathrm{NiO}$ & 0 & 0,02 & 0 & 0 & 0 & 0 & 0,04 & 0 & 0 & 0 & 0 & 0 & 0 & 0 & 0 & 0 & 0 & 0 & 0 \\
\hline Total & 99,74 & 100,56 & 99,93 & 100,37 & 100,25 & 100,47 & 100,05 & 100,48 & 100,78 & 100,65 & 100,6 & 100,29 & 100,41 & 100,46 & 100,55 & 100,85 & 100,46 & 100,44 & 100,5 \\
\hline TSi & 1,968 & 1,964 & 1,983 & 1,967 & 1,974 & 1,973 & 1,958 & 1,981 & 1,996 & 1,998 & 1,991 & 1,995 & 1,987 & 1,991 & 1,987 & 1,986 & 1,998 & 1,985 & 1,993 \\
\hline TAl & 0,009 & 0,009 & 0,008 & 0,007 & 0,007 & 0,007 & 0,009 & 0,008 & 0,004 & 0,002 & 0,003 & 0,001 & 0,000 & 0,002 & 0,002 & 0,001 & 0,002 & 0,001 & 0,002 \\
\hline TFe3 & 0,000 & 0,000 & 0,000 & 0,000 & 0,000 & 0,000 & 0,000 & 0,000 & 0,000 & 0,000 & 0,000 & 0,000 & $0, \infty 00$ & 0,000 & 0,000 & 0,000 & 0,000 & 0,000 & 0,000 \\
\hline MlAl & 0,000 & 0,000 & 0,000 & 0,000 & 0,000 & 0,000 & 0,000 & 0,000 & 0,000 & 0,001 & 0,000 & 0,000 & 0,000 & 0,000 & 0,000 & 0,000 & 0,000 & 0,000 & 0,000 \\
\hline MlTi & 0,000 & 0,000 & 0,001 & 0,001 & 0,000 & 0,002 & 0,000 & 0,000 & 0,000 & 0,001 & 0,000 & 0,000 & $0, \infty 00$ & 0,000 & 0,000 & 0,000 & 0,000 & 0,002 & 0,000 \\
\hline $\mathrm{M} 1 \mathrm{Fe} 3$ & 0,000 & 0,000 & 0,000 & 0,000 & 0,000 & 0,000 & 0,000 & 0,000 & 0,000 & 0,000 & 0,000 & 0,000 & 0,000 & 0,000 & 0,000 & 0,000 & 0,000 & 0,000 & 0,000 \\
\hline $\mathrm{M} 1 \mathrm{Fe} 2$ & 0,006 & 0,007 & 0,011 & 0,007 & 0,011 & 0,005 & 0,003 & 0,01 & 0,005 & 0,002 & 0,003 & 0,000 & 0,000 & 0,001 & 0,000 & 0,003 & 0,001 & 0,003 & 0,000 \\
\hline $\mathrm{M} 1 \mathrm{Cr}_{\mathrm{r}}$ & 0,000 & 0,000 & 0,000 & 0,000 & 0,000 & 0,000 & 0,000 & 0,000 & 0,000 & 0,000 & 0,001 & 0,000 & 0,000 & 0,000 & 0,001 & 0,000 & 0,000 & 0,001 & 0,000 \\
\hline M1Mg & 0,994 & 0,992 & 0,988 & 0,992 & 0,989 & 0,993 & 0,996 & 0,99 & 0,991 & 0,99 & 0,994 & 1.000 & 0,999 & 0,999 & 0,998 & 0,997 & 0,998 & 0,992 & 0,993 \\
\hline $\mathrm{M} 1 \mathrm{Ni}$ & 0,000 & 0,001 & 0,000 & 0,000 & 0,000 & 0,000 & 0,001 & 0,000 & 0,000 & 0,000 & 0,000 & 0,000 & 0,000 & 0,000 & 0,000 & 0,000 & 0,000 & 0,000 & 0,000 \\
\hline M2Mg & 0,000 & 0,000 & 0,000 & 0,000 & 0,000 & 0,000 & 0,000 & 0,000 & 0,000 & 0,000 & 0,000 & 0,005 & 0,009 & 0,000 & 0,003 & 0,000 & 0,000 & 0,000 & 0,000 \\
\hline $\mathrm{M} 2 \mathrm{Fe} 2$ & 0,009 & 0,006 & 0,004 & 0,011 & 0,002 & 0,012 & 0,01 & 0,002 & 0,000 & 0,000 & 0,000 & 0,004 & 0,002 & 0,001 & 0,003 & 0,003 & 0,003 & 0,000 & 0,000 \\
\hline $\mathrm{M} 2 \mathrm{Mn}$ & 0,000 & 0,001 & 0,000 & 0,002 & 0,000 & 0,000 & 0,000 & 0,001 & 0,000 & 0,001 & 0,000 & 0,000 & 0,000 & 0,000 & 0,001 & 0,001 & 0,000 & 0,000 & 0,000 \\
\hline $\mathrm{M} 2 \mathrm{Ca}$ & 1,009 & 1,014 & 1,002 & 1,008 & 1,014 & 1,004 & 1,015 & 1,002 & 1,002 & 1,002 & 1,006 & 0,995 & 1,002 & 1,006 & 1,004 & 1,009 & 0,997 & 1,016 & 1,012 \\
\hline $\mathrm{M} 2 \mathrm{Na}$ & 0,005 & 0,006 & 0,005 & 0,005 & 0,003 & 0,004 & 0,006 & 0,006 & 0,001 & 0,003 & 0,001 & 0,001 & 0,000 & 0,000 & 0,001 & 0,001 & 0,000 & 0,000 & 0,000 \\
\hline M2K & 0,000 & 0,000 & 0,000 & 0,000 & 0,000 & 0,000 & 0,001 & 0,000 & 0,000 & 0,000 & 0,000 & 0,000 & 0,000 & 0,000 & 0,000 & 0,000 & 0,000 & 0,000 & 0,000 \\
\hline Sum_cat & 4.000 & 4.000 & 4.000 & 4.000 & 4.000 & 4.000 & 3,999 & 4.000 & 4.000 & 4.000 & 4.000 & 4.000 & 4.000 & 4.000 & 4.000 & 4.000 & 4.000 & 4.000 & 4.000 \\
\hline
\end{tabular}


Anexo Tabela A-7. (continuação).

\begin{tabular}{|c|c|c|c|c|c|c|c|c|c|c|c|c|c|c|c|c|}
\hline $\begin{array}{l}\text { amostra } \\
\text { análise }\end{array}$ & $\begin{array}{c}05 \mathrm{~A} 2 \\
365\end{array}$ & $\begin{array}{c}05 \mathrm{~A} 2 \\
366\end{array}$ & $05 \mathrm{~A} 2$ & 05A2 & $05 \mathrm{~A} 2$ & 05A2 & $05 \mathrm{~A} 2$ & 05A2 & 05A2 & $05 \mathrm{~A} 2$ & $05 \mathrm{~A} 2$ & $05 \mathrm{~A} 2$ & 05A2 & 05A2 & $05 \mathrm{~A} 2$ & 05A2 \\
\hline & 503 & $\frac{360}{5531}$ & $\frac{367}{5520}$ & 368 & 369 & 370 & 371 & 372 & 373 & 374 & 375 & 376 & 377 & 378 & 379 & 380 \\
\hline $\mathrm{SiO}_{2}$ & 55,3 & 55,32 & 55,38 & 55,28 & 55,14 & 55,44 & 55,34 & 55,53 & 55,25 & 55,1 & 55,49 & 55,35 & 55,45 & 55,31 & 55,31 & 55,49 \\
\hline $\mathrm{TiO}_{2}$ & 0 & 0,02 & 0 & 0,04 & 0 & 0 & 0,06 & 0,03 & 0 & 0,05 & 0 & 0,08 & 0 & 0 & 0,02 & 0 \\
\hline $\mathrm{Al}_{2} \mathrm{O}_{3}$ & 0,04 & 0,01 & 0 & 0,03 & 0 & 0 & 0,01 & 0,01 & 0,07 & 0,01 & 0,04 & 0,02 & 0,01 & 0,02 & 0,03 & 0,03 \\
\hline $\mathrm{FeO}$ & 0,07 & 0,05 & 0,12 & 0,09 & 0,06 & 0,17 & 0,16 & 0,11 & 0,12 & 0,02 & 0,06 & 0,14 & 0,08 & 0,14 & 0,1 & 0,15 \\
\hline $\mathrm{MnO}$ & 0 & 0 & 0 & 0 & 0 & 0,03 & 0,02 & 0,06 & 0 & 0 & 0 & 0,06 & 0 & 0,02 & 0 & 0 \\
\hline MgO & 18,61 & 18,66 & 18,68 & 18,71 & 18,57 & 18,5 & 18,7 & 18,72 & 18,73 & 18,55 & 18,61 & 18,57 & 18,6 & 18,55 & 18,59 & 18,47 \\
\hline $\mathrm{CaO}$ & 26,25 & 25.97 & 26,18 & 26,02 & 26,05 & 25,91 & 25,93 & 26,03 & 25,84 & 26,15 & 26,12 & 26,16 & 26,06 & 26,33 & 26,18 & 26.25 \\
\hline $\mathrm{Na}_{2} \mathrm{O}$ & 0,02 & 0 & 0 & 0,03 & 0,05 & 0,02 & 0,03 & 0,04 & 0,05 & 0,02 & 0,01 & 0,01 & 0,01 & 0,02 & 0,01 & 0,02 \\
\hline $\mathrm{K}_{2} \mathrm{O}$ & 0 & 0 & 0 & 0,01 & 0 & 0 & 0 & 0,01 & 0,04 & 0,01 & 0 & 0 & 0 & 0 & 0 & 0 \\
\hline $\mathrm{Cr}_{2} \mathrm{O}_{3}$ & 0,02 & 0 & 0 & 0 & 0,01 & 0 & 0 & 0,04 & 0 & 0,02 & 0,01 & 0 & 0 & 0,08 & 0,01 & 0,01 \\
\hline $\mathrm{Fe}_{2} \mathrm{O}_{3}$ & 0 & 0 & 0 & 0 & 0 & 0 & 0 & 0 & 0 & 0 & 0 & 0 & 0 & 0 & 0 & 0 \\
\hline $\mathrm{NiO}$ & 0 & 0 & 0 & 0 & 0 & 0 & 0 & 0 & 0 & 0 & 0 & 0 & 0 & 0 & 0 & 0 \\
\hline Total & 100,31 & 100,03 & 100,36 & 100,21 & 99,88 & 100,07 & 100,25 & 100,58 & 100,1 & 99,93 & 100,34 & 100,39 & 100,21 & 100,47 & 100,25 & 100,42 \\
\hline TSi & 1,987 & 1,993 & 1,989 & 1,987 & 1,989 & 1,998 & 1,989 & 1,990 & 1,988 & 1,987 & 1,993 & 1,989 & 1,995 & 1,985 & 1,989 & 1,993 \\
\hline $\mathrm{TAl}$ & 0,002 & 0,000 & 0,000 & 0,001 & 0,000 & 0,000 & 0,000 & 0,000 & 0,003 & 0,000 & 0,002 & 0,001 & 0,000 & 0,001 & 0,001 & 0,001 \\
\hline $\mathrm{TFe} 3$ & 0,000 & 0,000 & 0,000 & 0,000 & 0,000 & 0,000 & 0,000 & 0,000 & 0,000 & 0,000 & 0,000 & 0,000 & 0,000 & 0,000 & 0,000 & 0,000 \\
\hline M1A1 & 0,000 & 0,000 & 0,000 & 0,000 & 0,000 & 0,000 & 0,000 & 0,000 & 0,000 & 0,000 & 0,000 & 0,000 & 0,000 & 0,000 & 0,000 & 0,000 \\
\hline MITi & 0,000 & 0,001 & 0,000 & 0,001 & 0,000 & 0,000 & 0,002 & 0,001 & 0,000 & 0,001 & 0,000 & 0,002 & 0,000 & 0,000 & 0,001 & 0,000 \\
\hline M1Fe3 & 0,000 & 0,000 & 0,000 & 0,000 & 0,000 & 0,000 & 0,000 & 0,000 & 0,000 & 0,000 & 0,000 & 0,000 & 0,000 & $0, \infty 00$ & 0,000 & 0,000 \\
\hline M1Fe2 & 0,002 & 0,000 & 0,000 & 0,000 & 0,001 & 0,005 & 0,000 & 0,000 & 0,000 & 0,001 & 0,002 & 0,003 & 0,002 & 0,004 & 0,003 & 0,005 \\
\hline $\mathrm{M} 1 \mathrm{Cr}$ & 0,001 & 0,000 & 0,000 & 0,000 & 0,000 & 0,000 & 0,000 & 0,001 & 0,000 & 0,001 & 0,000 & 0,000 & 0,000 & 0.002 & 0,000 & 0,000 \\
\hline $\mathrm{M} 1 \mathrm{Mg}$ & 0,997 & 0,999 & 1.000 & 0,999 & 0,999 & 0.994 & 0,998 & 0,998 & 1.000 & 0,997 & 0,997 & 0,995 & 0,997 & 0.993 & 0,997 & 0,989 \\
\hline $\mathrm{M} 1 \mathrm{Ni}$ & 0,000 & 0,000 & 0,000 & 0,000 & 0,000 & 0,000 & 0,000 & 0,000 & 0,000 & 0,000 & 0,000 & 0,000 & 0,000 & 0,000 & 0,000 & 0,000 \\
\hline $\mathrm{M} 2 \mathrm{Mg}$ & 0,000 & 0,003 & 0,000 & 0,004 & 0,000 & 0,000 & 0,004 & 0,002 & 0,004 & 0,000 & 0,000 & 0,000 & 0,000 & 0,000 & 0,000 & 0,000 \\
\hline $\mathrm{M} 2 \mathrm{Fe} 2$ & 0,000 & 0,002 & 0,004 & 0,003 & 0,001 & 0,000 & 0,005 & 0,003 & 0,004 & 0,000 & 0,000 & 0,001 & 0,000 & 0,000 & 0,000 & 0,000 \\
\hline M2Mn & 0,000 & 0,000 & 0,000 & 0,000 & 0,000 & 0,001 & 0,001 & 0,002 & 0,000 & 0,000 & 0,000 & 0,002 & 0,000 & 0,001 & 0,000 & 0,000 \\
\hline $\mathrm{M} 2 \mathrm{Ca}$ & 1.011 & 1.002 & 1.007 & 1.002 & 1.007 & 1.001 & 0,999 & 0,999 & 0,996 & 1.011 & 1.005 & 1.007 & 1.004 & 1.013 & 1.009 & 1.010 \\
\hline $\mathrm{M} 2 \mathrm{Na}$ & 0,001 & 0,000 & 0,000 & 0,002 & 0,003 & 0,001 & 0,002 & 0,003 & 0,003 & 0,001 & 0,001 & 0,001 & 0,001 & 0,001 & 0,001 & 0,001 \\
\hline $\mathrm{M} 2 \mathrm{~K}$ & 0,000 & 0,000 & 0,000 & 0,000 & 0,000 & 0,000 & 0,000 & 0,000 & 0,002 & 0,000 & 0,000 & 0,000 & 0,000 & 0,000 & 0,000 & 0,000 \\
\hline Sum_cat & 4.000 & 4.000 & 4.000 & 4.000 & 4.000 & 4.000 & 4.000 & 4.000 & 3.998 & 4.000 & 4.000 & 4.000 & 4.000 & 4.000 & 4.000 & 4.000 \\
\hline
\end{tabular}


Anexo Tabela A-8. Dados microtermométricos e parâmetros calculados de inclusôes fluidas da amostra PTI02AI (IF = inclusão fluida; Te = temperatura eutética; Tfg = temperatura de fusão do gelo; Thtot = temperatura de homogeneização total; $\mathrm{V}=$ = volume proporcional da fase gasosa; Densidade calculada em $\mathrm{g} / \mathrm{ml}$; $\mathrm{XH}_{2} \mathrm{O}=$ fração molar de água; $\mathrm{XNaCl}=$ fração molar de $\mathrm{NaCl}$; Salin. = salinidade em $\mathrm{NaCl}$ equivalente \%).

\begin{tabular}{|c|c|c|c|c|c|c|c|c|}
\hline \multicolumn{9}{|c|}{ Amostra PTI-102-AI - Frag 7a } \\
\hline IF & Te & Tfg & Thitot & $\mathbf{V}$ & Densidade & $\mathbf{X H H}_{2} \mathbf{O}$ & $\mathrm{XNaCl}$ & Salin. \\
\hline 1 & $-41,0$ & $-2,1$ & 189,7 & 12,4 & 0,9066 & 0,978 & 0,022 & 3,59 \\
\hline 2 & $-40,4$ & $-2,6$ & 165,5 & 10,3 & 0,9354 & 0,973 & 0,027 & 4,39 \\
\hline 3 & $-42,2$ & $-1,5$ & & 20 & 0,8133 & 0,984 & 0,016 & 2,60 \\
\hline 4 & $-39,1$ & $-1,4$ & 220,4 & 15,9 & 0,8603 & 0,985 & 0,015 & 2,44 \\
\hline 5 & $-40,8$ & $-2,9$ & 166,5 & 10,6 & 0,9375 & 0,970 & 0,030 & 4,86 \\
\hline 6 & $-43,4$ & $-2,8$ & 164,2 & 10,3 & 0,9385 & 0,971 & 0,029 & 4,70 \\
\hline 7 & $-43,5$ & $-2,0$ & 199,2 & 13,4 & 0,8950 & 0,979 & 0,021 & 3,42 \\
\hline 8 & $-41,3$ & $-1,7$ & 208,5 & 14,4 & 0,8800 & 0,982 & 0,018 & 2,93 \\
\hline 9 & $-43,7$ & $-1,4$ & 171,7 & 10,4 & 0,9168 & 0,985 & 0,015 & 2,44 \\
\hline 10 & $-41,1$ & $-1,5$ & & & & & & \\
\hline 11 & $-42,8$ & $-2,2$ & 127,6 & 7,3 & 0,9613 & 0,977 & 0,023 & 3,75 \\
\hline 12 & $-42,0$ & $-1,8$ & 210,4 & 14,7 & 0,8791 & 0,981 & 0,019 & 3,10 \\
\hline 13 & $-43,9$ & $-1,8$ & & 30 & 0,7141 & 0,981 & 0,019 & 3,10 \\
\hline 14 & $-42,8$ & $-1,8$ & 172,9 & 10,7 & 0,9202 & 0,981 & 0,019 & 3,10 \\
\hline 15 & $-42,5$ & $-1,8$ & 220,1 & 15,8 & 0,8668 & 0,981 & 0,019 & 3,10 \\
\hline 16 & $-44,0$ & $-1,8$ & 205,0 & 14 & 0,8856 & 0,981 & 0,019 & 3,10 \\
\hline 17 & $-41,4$ & $-1,5$ & 199,8 & 13,4 & 0,8877 & 0,984 & 0,016 & 2,60 \\
\hline 18 & $-41,1$ & $-1,4$ & & & & & & \\
\hline 19 & $-46,0$ & $-1,7$ & 212,2 & 14,9 & 0,8754 & 0,982 & 0,018 & 2,93 \\
\hline 20 & 44,4 & $-2,0$ & 182,6 & 11,7 & 0,9128 & 0,979 & 0,021 & 3,42 \\
\hline 21 & $-40,3$ & $-1,4$ & 222,0 & 16,1 & 0,8581 & 0,985 & 0,015 & 2,44 \\
\hline 22 & $-42,4$ & $-1,5$ & 205,3 & 14 & 0,8811 & 0,984 & 0,016 & 2,60 \\
\hline 23 & $-44,8$ & $-1,5$ & 218,9 & 15,7 & 0,8638 & 0,984 & 0,016 & 2,60 \\
\hline 24 & $-46,4$ & $-1,5$ & 214,6 & 15,2 & 0,8695 & 0,984 & 0,016 & 2,60 \\
\hline 25 & $-45,2$ & $-1,8$ & 214,6 & 15,2 & 0,8738 & 0,981 & 0,019 & 3,10 \\
\hline 26 & $-41,9$ & $-1,4$ & 195,1 & 12,8 & 0,8918 & 0,985 & 0,015 & 2,44 \\
\hline 27 & $-43,3$ & $-0,7$ & & 25 & 0,7554 & 0,992 & 0,008 & 1,26 \\
\hline 28 & $-39,5$ & $-1,7$ & 215,8 & 15,3 & 0,8709 & 0,982 & 0,018 & 2,93 \\
\hline 29 & $-44,7$ & $-2,6$ & & 20 & 0,8234 & 0,973 & 0,027 & 4,39 \\
\hline 30 & $-41,0$ & $-1,8$ & 229,5 & 17,1 & 0,8542 & 0,981 & 0,019 & 3,10 \\
\hline
\end{tabular}




\begin{tabular}{|c|c|c|c|c|c|c|c|c|}
\hline \multirow[b]{2}{*}{ IF } & \multirow[b]{2}{*}{ Te } & \multirow[b]{2}{*}{ Tfg } & \multicolumn{3}{|c|}{ Amostra P'TI-02-AI - Frag 7a } & \multirow[b]{2}{*}{$\mathrm{XH}_{2} \mathrm{O}$} & \multirow[b]{2}{*}{$\mathrm{XNaCl}$} & \multirow[b]{2}{*}{ Salin. } \\
\hline & & & Thtot & $\mathbf{v}$ & Densidade & & & \\
\hline 31 & $-43,7$ & $-1,5$ & 219,7 & 15,8 & 0,8628 & 0,984 & 0,016 & 2,6 \\
\hline 32 & $-43,9$ & $-1,6$ & 214,6 & 15,2 & 0,8709 & 0,983 & 0,017 & 2,77 \\
\hline 33 & $-41,9$ & $-1,7$ & 215,8 & 15,3 & 0,8709 & 0,982 & 0,018 & 2,93 \\
\hline 34 & $-46,0$ & $>0$ & 146,8 & 7,5 & 0,9236 & 1,000 & 0,000 & 0,00 \\
\hline 35 & $-43,2$ & $-1,9$ & 215,8 & 15,3 & 0,8738 & 0,980 & 0,020 & 3,26 \\
\hline 36 & $-46,2$ & $-1,8$ & 215,8 & 15,3 & 0,8723 & 0,981 & 0,019 & 3,10 \\
\hline 37 & $-45,6$ & $-1,7$ & 225,3 & 16,5 & 0,8583 & 0,982 & 0,018 & 2,93 \\
\hline 38 & $-43,3$ & $-1,8$ & 235,0 & 17,8 & 0,8465 & 0,981 & 0,019 & 3,10 \\
\hline 39 & $-40,6$ & $-1,7$ & 219,3 & 15,8 & 0,8663 & 0,982 & 0,018 & 2,93 \\
\hline 40 & $-46,6$ & $-1,7$ & 214,6 & 15,2 & 0,8724 & 0,982 & 0,018 & 2,93 \\
\hline 41 & $-42,9$ & $-1,7$ & 214,6 & 15,2 & 0,8724 & 0,982 & 0,018 & 2,93 \\
\hline 42 & $-42,1$ & $-1,7$ & 217,9 & 15,6 & 0,8682 & 0,982 & 0,018 & 2,93 \\
\hline IF & Te & Tfg & Thtot & $\mathbf{v}$ & Densidade & $\mathrm{XHH}_{2} \mathrm{O}$ & $\mathrm{XNaCl}$ & Salin. \\
\hline 43 & $-41,4$ & $-1,9$ & 169,6 & 10,4 & 0,9244 & 0,980 & 0,020 & 3,26 \\
\hline 44 & $-43,5$ & $-1,7$ & & 10 & 0,9171 & 0,982 & 0,018 & 2,93 \\
\hline 45 & $-45,2$ & $-1,8$ & & & & & & \\
\hline 46 & $-47,5$ & $-2,2$ & & & & & & \\
\hline a & & & 215,5 & & & & & \\
\hline b & & & 215,5 & & & & & \\
\hline c & & & 226,9 & & & & & \\
\hline
\end{tabular}

Amostra PTI-02-AI - Frag 4B

\begin{tabular}{ccccccccc}
\multicolumn{7}{c}{ Amostra PTI-02-AI - Frag 4B } \\
\hline 1 & $-45,2$ & $-2,0$ & 168,2 & 10,3 & 0,9268 & 0,979 & 0,021 & 3,42 \\
2 & $-42,7$ & $-1,9$ & 190,9 & 12,4 & 0,9029 & 0,980 & 0,020 & 3,26 \\
3 & $-45,2$ & $-1,9$ & 207,4 & 14,3 & 0,8841 & 0,980 & 0,020 & 3,26 \\
4 & $-45,4$ & $-2,0$ & 201,9 & 13,7 & 0,8919 & 0,979 & 0,021 & 3,42 \\
5 & & & 193,9 & $\sim 15$ & & & & \\
6 & & & 141,8 & -10 & & & & \\
7 & $-42,6$ & $-2,1$ & 191,8 & 12,7 & 0,9044 & 0,978 & 0,022 & 3,59 \\
8 & $-45,9$ & $-2,0$ & 205,6 & 14,1 & 0,8876 & 0,979 & 0,021 & 3,42 \\
9 & $-46,1$ & $-2,0$ & 212,0 & 14,9 & 0,8799 & 0,979 & 0,021 & 3,42 \\
10 & & & & $\sim 20$ & & & & \\
11 & $-43,6$ & $-1,9$ & 204,8 & 14 & 0,8872 & 0,980 & 0,020 & 3,26 \\
12 & $-47,9$ & $-4,7$ & 200,2 & 14,1 & 0,9248 & 0,953 & 0,047 & 7,55 \\
13 & $-42,0$ & $-2,1$ & 185,1 & 12 & 0,9114 & 0,978 & 0,022 & 3,59 \\
14 & $-47,4$ & $-2,0$ & 199,2 & 13,4 & 0,8950 & 0,979 & 0,021 & 3,42 \\
\hline
\end{tabular}




\begin{tabular}{|c|c|c|c|c|c|c|c|c|}
\hline $\mathbf{I F}$ & $\mathrm{Te}$ & $\mathrm{rfg}$ & Thtot & $\mathrm{v}$ & Densidade & $\mathrm{XH}_{2} \mathrm{O}$ & $\mathrm{XNaCl}$ & Salin. \\
\hline 15 & $-41,6$ & $-1,9$ & 200,5 & 13,5 & 0,8922 & 0,980 & 0,020 & 3,26 \\
\hline 16 & $-43,1$ & $-2,1$ & 167,4 & 10,3 & 0,9286 & 0,978 & 0,022 & 3,59 \\
\hline 17 & $-41,6$ & $-2,1$ & & 10 & 0,9212 & 0,978 & 0,022 & 3,59 \\
\hline 18 & $-40,6$ & $-2,1$ & & 10 & 0,9212 & 0,978 & 0,022 & 3,59 \\
\hline 19 & $-47,9$ & $-2,0$ & 197,8 & 13,2 & 0,8965 & 0,979 & 0,021 & 3,42 \\
\hline 20 & $-44,6$ & $-2,0$ & 133,6 & 7,6 & 0,9553 & 0,979 & 0,021 & 3,42 \\
\hline 21 & $-45,8$ & $-2,2$ & 175,0 & 11 & 0,9226 & 0,977 & 0,023 & 3,75 \\
\hline 22 & $-40,7$ & $-2,0$ & & 20 & 0,8180 & 0,979 & 0,021 & 3,42 \\
\hline 23 & & & 131,1 & $\sim 10$ & & & & \\
\hline 24 & & & 131,1 & $\sim 10$ & & & & \\
\hline 25 & $-43,6$ & $-2,2$ & 177,5 & 11,2 & 0,9201 & 0,977 & 0,023 & 3,75 \\
\hline 26 & $-43,7$ & $-2,0$ & 211,9 & 14,8 & 0,8800 & 0,979 & 0,021 & 3,42 \\
\hline 27 & $-44,9$ & $-2,2$ & 196,9 & 10,6 & 0,9274 & 0,977 & 0,023 & 3,75 \\
\hline 28 & 44,3 & $-2,2$ & 191,4 & 12,6 & 0,9060 & 0,977 & 0,023 & 3,75 \\
\hline 29 & $-43,1$ & $-2,2$ & 195,0 & 13 & 0,9021 & 0,977 & 0,023 & 3,75 \\
\hline 30 & $-39,0$ & $-2,2$ & 186,6 & 12,1 & 0,9110 & 0,977 & 0,023 & 3,75 \\
\hline 31 & & & & $\sim 20$ & & & & \\
\hline 32 & & & 204,2 & $\sim 10$ & & & & \\
\hline 33 & $-42,7$ & $-2,2$ & & 10 & 0,9222 & 0,977 & 0,023 & 3,75 \\
\hline 34 & $-44,3$ & $-1,8$ & 193,2 & 12,7 & 0,8991 & 0,981 & 0,019 & 3,10 \\
\hline 35 & & & 144,0 & $\sim 10$ & & & & \\
\hline 36 & $-45,8$ & $-2,4$ & 196,6 & 13,2 & 0,9029 & 0,975 & 0,025 & 4,07 \\
\hline 37 & $-44,1$ & $-2,2$ & 192,3 & 12,7 & 0,9051 & 0,977 & 0,023 & 3,75 \\
\hline 38 & & $-2,2$ & & 10 & 0,9222 & 0,977 & 0,023 & 3,75 \\
\hline 39 & & $-2,2$ & & 10 & 0,9222 & 0,977 & 0,023 & 3,75 \\
\hline 40 & & $-2,2$ & & 10 & 0,9222 & 0,977 & 0,023 & 3,75 \\
\hline 41 & & $-2,2$ & & & & 0,977 & 0,023 & 3,75 \\
\hline 42 & $-45,6$ & $-2,5$ & 196,1 & 13,2 & 0,9046 & 0,974 & 0,026 & 4,23 \\
\hline 43 & $-43,8$ & $-2,3$ & 185,4 & 12 & 0,9134 & 0,976 & 0,024 & 3,91 \\
\hline 44 & $-46,3$ & $-2,1$ & 209,9 & 14,6 & 0,8838 & 0,978 & 0,022 & 3,59 \\
\hline 45 & $-46,0$ & $-2,2$ & 211,6 & 14,8 & 0,8831 & 0,977 & 0,023 & 3,75 \\
\hline 46 & $-40,0$ & $-2,2$ & & 10 & 0,9222 & 0,977 & 0,023 & 3,75 \\
\hline 47 & $-41,1$ & $-2,1$ & & 10 & 0,9212 & 0,978 & 0,022 & 3,59 \\
\hline 48 & $-44,5$ & $-1,7$ & 211,4 & 14,8 & 0,8764 & 0,982 & 0,018 & 2,93 \\
\hline c & $-47,5$ & $-2,2$ & & & & 0,977 & 0,023 & 3,75 \\
\hline
\end{tabular}


Amostra PTI.02 AI - Frag 12

\begin{tabular}{|c|c|c|c|c|c|c|c|c|}
\hline IF & $\mathrm{Te}$ & $\mathrm{Tfg}$ & Thtot & $\mathrm{v}$ & Densidade & $\mathrm{XH}_{2} \mathrm{O}$ & $\mathrm{XNaCl}$ & Salin. \\
\hline 1 & $-46,5$ & $-1,9$ & 266,2 & 22,5 & 0,7999 & 0,980 & 0,020 & 3,26 \\
\hline 2 & $-42,4$ & $-1,8$ & 216,1 & 15,3 & 0,8719 & 0,981 & 0,019 & 3,10 \\
\hline 3 & $-42,6$ & $-1,7$ & 210,2 & 14,6 & 0,8779 & 0,982 & 0,018 & 2,93 \\
\hline 4 & $-43,9$ & $-2,0$ & 238,9 & 18,3 & 0,8442 & 0,979 & 0,021 & 3,42 \\
\hline 5 & $-42,1$ & $-1,8$ & 207,8 & 14,3 & 0,8822 & 0,981 & 0,019 & 3,10 \\
\hline 6 & $-43,2$ & $-1,6$ & 193,4 & 12,7 & 0,8964 & 0,983 & 0,017 & 2,77 \\
\hline 7 & $-45,1$ & $-1,7$ & 220,7 & 15,9 & 0,8645 & 0,982 & 0,018 & 2,93 \\
\hline 8 & $-42,9$ & $-1,8$ & 255,2 & 20,8 & 0,8160 & 0,981 & 0,019 & 3,10 \\
\hline 9 & $-43,2$ & $0 a>0$ & 118,7 & 5,3 & 0,9445 & $\sim 1$ & $\sim 0$ & $\sim 0$ \\
\hline 10 & $-41,0$ & $-1,7$ & 253,8 & 20,6 & 0,8164 & 0,982 & 0,018 & 2,93 \\
\hline 11 & $-41,9$ & $-1,6$ & 203,0 & 13,8 & 0,8853 & 0,983 & 0,017 & 2,77 \\
\hline 12 & $-40,9$ & $-1,6$ & 175,9 & 10,9 & 0,9150 & 0,983 & 0,017 & 2,77 \\
\hline 13 & $-43,6$ & $0 a>0$ & 224,1 & 15,8 & 0,8400 & $\sim 1$ & $\sim 0$ & $\sim 0$ \\
\hline 14 & $-41,9$ & $-2,1$ & 223,9 & 16,3 & 0,8663 & 0,978 & 0,022 & 3,59 \\
\hline 15 & $-44,2$ & $0 a>0$ & 118,3 & 5,3 & 0,9448 & $\sim 1$ & $\sim 0$ & 0 \\
\hline 16 & $-45,5$ & $-2,0$ & 146,1 & 8,5 & 0,9458 & 0,979 & 0,021 & 3,42 \\
\hline 17 & $-45,0$ & $-1,9$ & 218,1 & 15,6 & 0,8708 & 0,980 & 0,020 & 3,26 \\
\hline 18 & $-46,2$ & $-2,0$ & 207,8 & 14,4 & 0,8850 & 0,979 & 0,021 & 3,42 \\
\hline 19 & $-48,6$ & $-1,9$ & 224,1 & 16,3 & 0,8630 & 0,980 & 0,020 & 3,26 \\
\hline 20 & $-45,0$ & 0,1 & 113,0 & 5 & 0,9483 & -1 & $\sim 0$ & -0 \\
\hline 21 & $-42,5$ & $0 a>0$ & 100,0 & 4,2 & 0,9566 & $\sim 1$ & $\sim 0$ & $\sim 0$ \\
\hline 22 & $-44,6$ & $-2,2$ & 237,9 & 18,1 & 0,8489 & 0,977 & 0,023 & 3,75 \\
\hline 23 & $-41,2$ & $-2,0$ & 172,0 & 10,7 & 0,9232 & 0,979 & 0,021 & 3,42 \\
\hline 24 & $-46,6$ & $-1,9$ & 237,5 & 18,1 & 0,8446 & 0,980 & 0,020 & 3,26 \\
\hline 25 & $-4 \mathrm{I}, 7$ & $-1,9$ & 254,1 & 20,6 & 0,8196 & 0,980 & 0,020 & 3,26 \\
\hline 26 & $-41,6$ & $-1,9$ & 224,4 & 16,4 & 0,8626 & 0,980 & 0,020 & 3,26 \\
\hline 27 & $-43,7$ & $0 a>0$ & & 8 & 0,9183 & $\sim 1$ & $\sim 0$ & $\sim 0$ \\
\hline 28 & & $0 \mathrm{a}>0$ & 147,0 & 7,5 & 0,9234 & $\sim 1$ & $\sim 0$ & $\sim 0$ \\
\hline 29 & $-44,0$ & $-1,8$ & 188,2 & 12,1 & 0,9046 & 0,981 & 0,019 & 3,10 \\
\hline 30 & $-44,2$ & $-1,6$ & I 88,6 & 12,2 & 0,9017 & 0,983 & 0,017 & 2,77 \\
\hline 31 & $-42,0$ & $-1,6$ & & 10 & 0,9160 & 0,983 & 0,017 & 2,77 \\
\hline 32 & $-44,7$ & & & 80 & & & & \\
\hline 33 & $-43,0$ & $-1,8$ & 252,8 & 20,4 & 0,8198 & 0,981 & 0,019 & 3,10 \\
\hline 34 & & $-2,5$ & 239,2 & 18,2 & 0,8518 & 0,974 & 0,026 & 4,23 \\
\hline $1 \mathrm{~b}$ & $-40,2$ & $-1,7$ & & 10 & 0,9171 & 0,982 & 0,018 & 2,93 \\
\hline $2 \mathrm{~b}$ & $-43,0$ & $-1,7$ & 223,7 & 16,3 & 0,8605 & 0,982 & 0,018 & 2,93 \\
\hline $3 b$ & $-43,0$ & $-1,8$ & & 10 & 0,9181 & 0,981 & 0,019 & 3,10 \\
\hline $4 b$ & $-42,5$ & $-2,0$ & & 25 & 0,7668 & 0,979 & 0,021 & 3,42 \\
\hline
\end{tabular}




\begin{tabular}{|c|c|c|c|c|c|c|c|c|}
\hline IF & $\mathrm{Te}$ & $\mathbf{T f g}$ & Thtot & $\mathbf{v}$ & Densidade & $\mathrm{XH}_{2} \mathrm{O}$ & $\mathrm{XNaCl}$ & Salin. \\
\hline $5 b$ & & $-1,7$ & & 8 & 0,9375 & 0,982 & 0,018 & 2,93 \\
\hline $6 \mathrm{~b}$ & $-42,9$ & $-2,1$ & & 20 & 0,8189 & 0,978 & 0,022 & 3,59 \\
\hline $7 b$ & $-43,7$ & $-1,8$ & 253,5 & 20,5 & 0,8187 & 0,981 & 0,019 & 3,10 \\
\hline $8 \mathrm{~b}$ & $-43,3$ & $-1,7$ & 181,3 & 11,4 & 0,9106 & 0,982 & 0,018 & 2,93 \\
\hline $10 \mathrm{~b}$ & $-44,1$ & $-2,1$ & 171,1 & 10,6 & 0,9252 & 0,978 & 0,022 & 3,59 \\
\hline $11 \mathrm{~b}$ & & & 84,8 & & & & & \\
\hline a & & & 134,3 & & & & & \\
\hline $\mathrm{b}$ & & & 138,3 & & & & & \\
\hline $\mathrm{c}$ & & & 138,3 & & & & & \\
\hline d & & & 224,8 & & & & & \\
\hline
\end{tabular}

\begin{tabular}{|c|c|c|c|c|c|c|c|c|}
\hline \multirow[b]{2}{*}{ IF } & \multirow[b]{2}{*}{ Te } & \multirow[b]{2}{*}{$\mathrm{Tfg}$} & \multicolumn{3}{|c|}{ Amostra PTI-02-AI - Frag 3C } & \multirow[b]{2}{*}{$\mathbf{X H}_{2} \mathbf{O}$} & \multirow[b]{2}{*}{$\mathrm{XNaCl}$} & \multirow[b]{2}{*}{ Salin } \\
\hline & & & Thtot & $\mathbf{v}$ & Densidade & & & \\
\hline 1 & $-45,1$ & $-1,5$ & & 5 & 0,9658 & 0,984 & 0,016 & 2,60 \\
\hline 2 & $-44,5$ & $-1,7$ & 137,8 & 7,7 & 0,9495 & 0,982 & 0,018 & 2,93 \\
\hline 3 & $-43,5$ & $+0,7$ & 129,2 & 6,1 & 0,9371 & $\sim 1$ & $\sim 0$ & $\sim 0$ \\
\hline 4 & $-42,8$ & $-0,3$ & 108,5 & 4,6 & 0,9581 & 0,996 & 0,004 & 0,57 \\
\hline 5 & $-42,2$ & $-1,8$ & 177,0 & 11 & 0,9161 & 0,981 & 0,019 & 3,10 \\
\hline 6 & $-42,5$ & $+0,8$ & & 5 & 0,9483 & $\sim 1$ & $\sim 0$ & $\sim 0$ \\
\hline 7 & $-45,0$ & $+4,1$ & 131,4 & 6,3 & 0,9355 & $\sim 1$ & $\sim 0$ & $\sim 0$ \\
\hline 8 & $-44,3$ & $-1,3$ & & 5 & 0,9636 & 0,986 & 0,014 & 2,27 \\
\hline 9 & $-45,1$ & $-1,3$ & 100,7 & 4,9 & 0,9711 & 0,986 & 0,014 & 2,27 \\
\hline 10 & $-44,6$ & $-1,5$ & 156,2 & 9 & 0,9324 & 0,984 & 0,016 & 2,60 \\
\hline 11 & $-45,4$ & $-0,9$ & 131,7 & 6,7 & 0,9468 & 0,990 & 0,010 & 1,59 \\
\hline 12 & $-43,9$ & $-0,9$ & & 5 & 0,9591 & 0,990 & 0,010 & 1,59 \\
\hline 13 & $-46,0$ & $-0,7$ & & 5 & 0,9568 & 0,992 & 0,008 & 1,26 \\
\hline 14 & $-44,6$ & $-1,4$ & & 8 & 0,9342 & 0,985 & 0,015 & 2,44 \\
\hline 15 & $-44,6$ & $-0,9$ & 136,9 & 7 & 0,9427 & 0,990 & 0,010 & 1,59 \\
\hline 16 & $-45,5$ & $-1,5$ & 126,5 & 6,7 & 0,9560 & 0,984 & 0,016 & 2,60 \\
\hline 17 & $-44,3$ & $-1,6$ & 139,4 & 7,7 & 0,9473 & 0,983 & 0,017 & 2,77 \\
\hline 18 & & & 132,4 & $<10$ & & & & \\
\hline 19 & $-45,1$ & $-2,0$ & & 5 & 0,9713 & 0,979 & 0,021 & 3,42 \\
\hline 20 & $-43,3$ & $+0,2$ & 125,6 & 5,9 & 0,9397 & $\sim 1$ & $\sim 0$ & $\sim 0$ \\
\hline 21 & $-47,6$ & $-1,6$ & 125,3 & 6,7 & 0,9578 & 0,983 & 0,017 & 2,77 \\
\hline 22 & $-47,2$ & $-1,7$ & & 8 & 0,9375 & 0,982 & 0,018 & 2,93 \\
\hline 23 & & & 87,5 & $<10$ & & & & \\
\hline
\end{tabular}




\begin{tabular}{|c|c|c|c|c|c|c|c|c|}
\hline \multicolumn{9}{|c|}{ Amostra PTI-02-AI - Frag 3C } \\
\hline IF & Te & $\mathrm{Tfg}$ & Thitot & $\mathbf{v}$ & Densidade & $\mathrm{XH}_{2} \mathrm{O}$ & $\mathrm{XNaCl}$ & Salin. \\
\hline 24 & $-43,7$ & $-1,3$ & 149,7 & 8 & 0,9360 & 0,986 & 0,014 & 2,27 \\
\hline 25 & $-45,8$ & $-1,6$ & & 10 & 0,9160 & 0,983 & 0,017 & 2,77 \\
\hline 26 & $-47,5$ & $+1,8$ & 123,7 & 5,7 & 0,9411 & $\sim 1$ & $\sim 0$ & $\sim 0$ \\
\hline 27 & $-45,7$ & $+4,1$ & 155,1 & 8,2 & 0,9166 & $\sim 1$ & $\sim 0$ & $\sim 0$ \\
\hline 28 & $-41,8$ & $+0,4$ & & 5 & 0,9483 & $\sim 1$ & $\sim 0$ & $\sim 0$ \\
\hline 29 & $-45,8$ & $-3,5$ & 136,5 & 8,7 & 0,9662 & 0,964 & 0,036 & 5,79 \\
\hline 30 & $-42,3$ & $-0,8$ & 149,7 & 8,1 & 0,9309 & 0,991 & 0,009 & 1,43 \\
\hline 31 & $-47,5$ & $-1,3$ & & 8 & 0,9332 & 0,986 & 0,014 & 2,27 \\
\hline 32 & $-39,2$ & $+0,3$ & 91,9 & 3,4 & 0,9614 & $\sim 1$ & $\sim 0$ & $\sim 0$ \\
\hline 33 & $-46,1$ & $-1,1$ & 132,6 & 6,9 & 0,9479 & 0,988 & 0,012 & 1,93 \\
\hline 34 & $-43,3$ & $-1,2$ & & 10 & 0,9118 & 0,987 & 0,013 & 2,10 \\
\hline 35 & $-44,7$ & $+0,6$ & 141,7 & 7,1 & 0,9227 & $\sim 1$ & $\sim 0$ & $\sim 0$ \\
\hline 36 & $-46,2$ & $-1,6$ & 137,5 & 7,6 & 0,9488 & 0,983 & 0,017 & 2,77 \\
\hline 37 & $-46,9$ & $-0,7$ & 132,1 & 6,6 & 0,9446 & 0,992 & 0,008 & 1,26 \\
\hline 38 & $-46,8$ & $-2,5$ & 137,5 & 8,1 & 0,9569 & 0,974 & 0,026 & 4,23 \\
\hline 39 & & & 136,5 & $<10$ & & & & \\
\hline 40 & $-48,0$ & $-1,6$ & 140,5 & 7,8 & 0,9465 & 0,983 & 0,017 & 2,77 \\
\hline 41 & $-49,0$ & & 129,7 & $<10$ & & & & \\
\hline 42 & $-49,6$ & $+1,9$ & 133,6 & 6,4 & 0,9339 & -1 & $\sim 0$ & $\sim 0$ \\
\hline 43 & & & 133,3 & $<10$ & & & & \\
\hline 44 & $-43,8$ & $-1,8$ & 133,3 & 7,4 & 0,9538 & 0,981 & 0,019 & 3,10 \\
\hline 45 & & $-1,8$ & & 8 & 0,9385 & 0,981 & 0,019 & 3,10 \\
\hline 46 & $-39,9$ & $-0,3$ & 133,8 & 6,4 & 0,9395 & 0,996 & 0,004 & 0,57 \\
\hline 47 & $-47,1$ & $-2,2$ & 134,1 & 7,7 & 0,9567 & 0,977 & 0,023 & 3,75 \\
\hline 48 & $-44,6$ & $-1,5$ & 131,2 & 7 & 0,9536 & 0,984 & 0,016 & 2,60 \\
\hline 49 & $-45,6$ & $+3,7$ & & 7 & 0,9283 & $\sim 1$ & $\sim 0$ & $\sim 0$ \\
\hline \multicolumn{9}{|l|}{50} \\
\hline 51 & $-46,8$ & $-1,6$ & 130,5 & 7,1 & 0,9540 & 0,983 & 0,017 & 2,77 \\
\hline 52 & $-45,3$ & $-1,6$ & 137,5 & 7,6 & 0,9488 & 0,983 & 0,017 & 2,77 \\
\hline 53 & $-42,0$ & $-1,7$ & 201,9 & 13,7 & 0,8879 & 0,982 & 0,018 & 2,93 \\
\hline 54 & $-46,5$ & $-1,6$ & 133,8 & 7,3 & 0,9516 & 0,983 & 0,017 & 2,77 \\
\hline \multicolumn{9}{|l|}{55} \\
\hline 56 & $-44,9$ & $-1,4$ & & 20 & 0,8124 & 0,985 & 0,015 & 2,44 \\
\hline 57 (a) & $-45,3$ & $+3,8$ & 225,5 & 16 & 0,8381 & $\sim 1$ & $\sim 0$ & $\sim 0$ \\
\hline $58(\mathrm{~m})$ & & $-1,4$ & & 5 & 0,9647 & 0,985 & 0,015 & 2,44 \\
\hline
\end{tabular}


Anexo Tabela A-9. Dados microtermométricos e parâmetros calculados de inclusões fluidas da amostra PTI05bac (IF = inclusão fluida; $\mathrm{TfCO} 2=$ temperatura de fusão do $\mathrm{CO}_{2} ; \mathrm{Te}=$ temperatura eutética; $\mathrm{Tfg}=$ temperatura de fusão do gelo; Tcl = temperatura de fusão do clatrato; Thtot = temperatura de homogeneização total; hom. tipo $=$ tipo de homogeneização, $\mathrm{g} \rightarrow$ gás, $1 \rightarrow$ líquido, $\mathrm{VCO} 2 / \mathrm{Vtotal}=$ proporção do volume de $\mathrm{CO} 2$ em relação ao volume total da inclusão).

\begin{tabular}{|c|c|c|c|c|c|c|c|c|c|}
\hline IF & $\mathrm{TfCO}_{2}$ & $\mathrm{Te}$ & $\mathrm{Tfg}$ & $\mathrm{Tcl}$ & $\mathrm{ThCO}_{2}$ & hom. tipo & Thtot & hom. tipo & $\mathrm{VCO}_{2} / \mathrm{Vtot}$ \\
\hline & grão 1 & & & & & & & & \\
\hline 1 & $-57,4$ & $-41,8$ & $-10,3$ & 8 & 30 & (g) & 377,1 & $\mathrm{CO} 2$ & 65 \\
\hline 2 & $-57,3$ & & & & & & 417,2 & $\mathrm{CO} 2$ & 70 a 75 \\
\hline 3 & $-57,3$ & $-47,3$ & $-7,6$ & 7,8 & & & 424,4 & $\mathrm{CO} 2$ & 70 \\
\hline 4 & $-57,3$ & & $-7,6$ & 8 & & & 438,4 & $\mathrm{CO} 2$ & 75 \\
\hline 5 & $-57,3$ & & & 7,8 & 29,8 & (g) & 406,6 & $\mathrm{CO} 2$ & 75 \\
\hline 6 & $-57,3$ & & & 7,8 & & & 386,6 & $\mathrm{CO} 2$ & 80 \\
\hline 7 & $-57,3$ & & & 7,8 & & & 450,1 & $\mathrm{CO} 2$ & 80 \\
\hline 8 & $-57,3$ & & & 8 & & & 407,5 & $\mathrm{CO} 2$ & 80 \\
\hline 9 & $-57,2$ & & & 8 & & & 389,8 & $\mathrm{CO} 2$ & 70 \\
\hline 10 & $-57,2$ & & & 8 & 21,2 & (g) & 394,2 & $\mathrm{CO} 2$ & 60 \\
\hline 11 & $-57,2$ & $-43,3$ & & 8,2 & 19,7 & (g) & 401,8 & $\mathrm{CO} 2$ & 60 \\
\hline 12 & & & & 8 & & & 374,6 & $\mathrm{CO} 2$ & 70 \\
\hline 13 & $-57,3$ & & & 8,4 & 9,5 & (g) & 397,9 & $\mathrm{CO} 2$ & 70 \\
\hline 14 & $-57,3$ & $-41,2$ & -9 & 8,1 & 9,8 & (g) & 431,3 & $\mathrm{CO} 2$ & 60 \\
\hline 15 & $-57,4$ & $-40,6$ & & 8,1 & 17,3 & (g) & 410,2 & $\mathrm{CO} 2$ & 60 \\
\hline 16 & $-57,4$ & & & 8,2 & 19,4 & (g) & 441,1 & $\mathrm{CO} 2$ & 70 \\
\hline 17 & $-57,2$ & $-45,3$ & & 7,5 & 12 & (g) & 399,9 & $\mathrm{CO} 2$ & 70 \\
\hline 18 & $-57,4$ & & & 8,1 & & & 388,8 & $\mathrm{CO} 2$ & 70 \\
\hline 19 & $-57,3$ & $-42,2$ & & 8 & & & 385,5 & $\mathrm{CO} 2$ & 60 \\
\hline 20 & $-57,4$ & & & 8 & 15,8 & (g) & 373 & $\mathrm{CO} 2$ & 70 \\
\hline 21 & $-57,2$ & & & 8 & 14,2 & (g) & & & 75 \\
\hline & grão 2 & & & & & & & & \\
\hline 1 & $-57,7$ & $-44,7$ & & 8,4 & & & & & 65 \\
\hline 2 & $-57,6$ & & & 7,8 & & & & & 75 \\
\hline 3 & $-57,7$ & $-43,8$ & & 9,6 & 23,2 & (g) & & & 50 \\
\hline 4 & $-57,9$ & & & 9,6 & 20,6 & (1) & & & 35 \\
\hline 5 & & & & 9,8 & 27,6 & (I) & & & 10 \\
\hline 6 & $-57,6$ & $-39,6$ & & 9,2 & 13,9 & (1) & & & 10 \\
\hline 7 & $-57,6$ & & & 7,8 & 24,3 & (g) & & & 75 \\
\hline 8 & & & & 9,4 & & & & & 75 \\
\hline 9 & & & & 8,6 & & & & & 80 \\
\hline
\end{tabular}




\begin{tabular}{|c|c|c|c|c|c|c|c|c|c|}
\hline IF & $\mathrm{TfCO}_{2}$ & $\mathrm{Te}$ & $\mathrm{Tfg}$ & $\mathrm{Tcl}$ & $\mathrm{ThCO}_{2}$ & hom. tipo & Thtot & hom tipo & $\mathrm{VCO}_{2} / \mathrm{Vtot}$ \\
\hline 10 & & & & $\sim 10$ & 27,3 & (g) & & & 40 \\
\hline II & & & & -10 & 28,1 & (g) & & & 40 \\
\hline 12 & $-57,3$ & & $-2,4$ & & & & & & 30 \\
\hline 13 & $-57,7$ & & & & 23,7 & (g) & & & 70 \\
\hline 14 & -58 & & & & 18,9 & (g) & & & 70 \\
\hline 15 & $-57,5$ & & & & 23,6 & (g) & & & 85 \\
\hline 16 & & & & 9,9 & & & & & 40 \\
\hline 17 & $-58,9$ & & & & & & & & 10 \\
\hline 18 & -58 & & & 9,8 & & & & & 65 \\
\hline & grão 3 & & & & & & & & \\
\hline 1 & $-57,4$ & & & & 27,6 & (l) & & & 100 \\
\hline 2 & $-57,3$ & & & & 30,9 & (1) & & & 100 \\
\hline 3 & $-57,2$ & & & 6,9 & 31,1 & (c) & & & 90 \\
\hline 4 & $-57,2$ & & & & & & & & 100 \\
\hline 5 & $-57,1$ & $-38,5$ & & & 25,2 & (l) & & & \\
\hline 6 & $-57,2$ & & & 6,9 & 31,1 & (c) & & & 90 \\
\hline 7 & $-57,4$ & & & & 24,1 & (I) & & & 100 \\
\hline 8 & $-57,4$ & & & & 21,7 & (l) & & & 100 \\
\hline 9 & $-57,3$ & & & & 24,1 & (l) & & & 100 \\
\hline 10 & $-57,3$ & & & & 23,2 & (l) & & & 100 \\
\hline 11 & $-57,5$ & & & & 29,8 & (g) & & & 100 \\
\hline 12 & $-57,7$ & & & 3 & 29,5 & (g) & & & 45 \\
\hline 13 & $-57,4$ & & & & 27,3 & (g) & & & 100 \\
\hline 14 & & & & & 31 & $(\mathrm{~g}, \mathrm{c})$ & & & 100 \\
\hline 15 & $-57,3$ & & & 3,75 & 31,1 & (c) & & & 70 \\
\hline 16 & & & & & 30,9 & (l) & & & 100 \\
\hline 17 & & & & & 30,4 & (g) & & & 100 \\
\hline 18 & $-57,6$ & $-46,1$ & & $-12,1$ & 24,8 & (g) & & & $45 / 50$ \\
\hline 19 & $-57,3$ & & & 9,2 & 22,3 & (I) & & & 80 \\
\hline 20 & $-57,3$ & & & & 31,1 & $(1, c)$ & & & 100 \\
\hline 21 & $-57,3$ & & & & 30,8 & (1) & & & 100 \\
\hline 22 & $-57,3$ & & & & 30,1 & (I) & & & 100 \\
\hline 23 & $-57,3$ & & & 3,2 & 23,8 & (g) & & & 75 \\
\hline 24 & $-57,5$ & & & & 14,2 & (l) & & & 95 \\
\hline 25 & $-57,3$ & & & & 28,4 & (g) & & & 90 \\
\hline 26 & $-57,5$ & & & & 24,2 & (g) & & & 90 \\
\hline
\end{tabular}


Anexo Tabela A-10. Dados microtermométricos e parâmetros calculados de inclusões fluidas da amostra PTI43AC (IF = inclusão fluida; TfCO2 = temperatura de fusão do CO $\mathrm{Te}=$ temperatura eutética; Tfg = temperatura de fusāo do gelo; $\mathrm{Tcl}=$ temperatura de fusão do clatrato; Thtot = temperatura de homogeneização total; hom. tipo = tipo de homogeneização, $\mathrm{g} \rightarrow$ gás, $1 \rightarrow$ líquido, VCO2/Vtotal = proporção do volume de $\mathrm{CO} 2$ em relação ao volume total da inclusão).

\begin{tabular}{|c|c|c|c|c|c|c|c|c|c|c|}
\hline IF & $\mathrm{TfCO}_{2}$ & $\mathrm{Te}$ & Tfg & $\mathrm{Tcl}$ & $\mathrm{ThCO}_{2}$ & hom. tipo & Thtot & hom. tipo & $\mathrm{VCO}_{2} / \mathrm{Vtot}$ & tipo inclusão \\
\hline 1 & $-58,4$ & & & 8.7 & 27,8 & (l) & 321,8 & $\mathrm{CO} 2$ & 60 & $\mathrm{H} 2 \mathrm{O}+\mathrm{CO} 2$ \\
\hline 2 & $-58,4$ & & & & 27,2 & (g) & & & 100 & $\mathrm{CO} 2$ \\
\hline 3 & $-59,1$ & & & & 17,2 & (l) & & & 100 & $\mathrm{CO} 2$ \\
\hline 7 & $-58,4$ & & & & & & & & 100 & $\mathrm{CO} 2$ \\
\hline 8 & -59 & & & & $-7,1$ & (l) & & & 100 & $\mathrm{CO} 2$ \\
\hline 10 & $-58,5$ & & & & $-5,9$ & (l) & & & 100 & $\mathrm{CO} 2$ \\
\hline 11 & $-58,6$ & & & & $-3,8$ & (1) & & & 100 & $\mathrm{CO} 2$ \\
\hline 12 & $-58,7$ & & & & $-3,9$ & (1) & & & 100 & $\mathrm{CO} 2$ \\
\hline 13 & $-58,7$ & & & & $-1,7$ & (l) & & & 100 & $\mathrm{CO} 2$ \\
\hline 14 & -58.9 & & & & $-3,3$ & (l) & & & 100 & $\mathrm{CO} 2$ \\
\hline 15 & $-58,1$ & & & & 27,2 & (g) & & & 100 & $\mathrm{CO} 2$ \\
\hline 16 & $-57,5$ & & & & 10,5 & (l) & & & 100 & $\mathrm{CO} 2$ \\
\hline 17 & $-58,5$ & & & & 17,7 & (l) & & & 100 & $\mathrm{CO} 2$ \\
\hline 18 & $-60,4$ & & & & $-11,1$ & (l) & & & 100 & $\mathrm{CO} 2$ \\
\hline 19 & $.58,9$ & & & & $-5,5$ & (l) & & & 100 & $\mathrm{CO} 2$ \\
\hline 20 & $-60,4$ & & & & $-8,9$ & (l) & & & 100 & $\mathrm{CO} 2$ \\
\hline 21 & $-57,9$ & & & & 7,5 & (l) & & & 100 & $\mathrm{CO} 2$ \\
\hline 22 & $-58,1$ & & & & $-4,1$ & (I) & & & 100 & $\mathrm{CO} 2$ \\
\hline 23 & -57.8 & & & & 29,3 & (g) & & & 100 & $\mathrm{CO} 2$ \\
\hline
\end{tabular}




\begin{tabular}{|c|c|c|c|c|c|c|c|c|c|c|c|}
\hline IF & $\mathrm{TfCO}_{2}$ & $\mathrm{Te}$ & $\mathrm{Tfg}$ & $\mathrm{Tcl}$ & $\mathrm{ThCO}_{2}$ & hom tipo & Thtot & hom. tipo & $\mathrm{VCO}_{2} / \mathrm{Vtot}$ & & \\
\hline 24 & -59 & -46 & --12 & 5,6 & 5,7 & (l) & 255 & $\mathrm{CO} 2 ? \mathrm{cr} ?$ & 45 & $\mathrm{H} 2 \mathrm{O}+\mathrm{CO} 2$ & \\
\hline 25 & $-59,3$ & & & & 6,2 & (l) & & & 100 & $\mathrm{CO} 2$ & \\
\hline 26 & $-57,5$ & & & & 18,7 & (l) & & & 100 & $\mathrm{CO} 2$ & \\
\hline 27 & & $-46,9$ & $-4,7$ & 9,4 & 27,8 & (l) & & & 5 a 10 & $\mathrm{H} 2 \mathrm{O}+\mathrm{CO} 2$ & \\
\hline 28 & $-57,7$ & & & & $-2,3$ & (l) & & & 100 & $\mathrm{CO} 2$ & \\
\hline 29 & & $-45,8$ & $-8,5$ & & & & 445,6 & (l) & 40 & ess. $\mathrm{H} 2 \mathrm{O}$ & 40 \\
\hline 30 & & $-45,8$ & $-8,5$ & & & & 538,5 & (l) & 35 & ess. $\mathrm{H} 2 \mathrm{O}$ & 35 \\
\hline 31 & $-58,3$ & & & & 23 & (1) & & & 100 & $\mathrm{CO} 2$ & \\
\hline 32 & & $-45,4$ & $-7,4$ & & & & 574,1 & (l) & 20 a 15 & ess.H2O & 20 a 15 \\
\hline 33 & $-58,3$ & $-43,9$ & & & $-13,1$ & (l) & 227,3 & $\mathrm{H} 2 \mathrm{O}$ & 40 a 45 & $\mathrm{H} 2 \mathrm{O}+\mathrm{CO} 2$ & \\
\hline 34 & $-59,8$ & $-46,8$ & & $-10,3$ & -21 & (1) & & & 20 a 25 & $\mathrm{H} 2 \mathrm{O}+\mathrm{CO} 2$ & \\
\hline 35 & & $-53,4$ & $-8,9$ & & & & 201,6 & (l) & $5 a 10$ & ess.H2O & 5 a 10 \\
\hline 36 & & $-49,5$ & & 3,3 & $-7,5$ & (l) & 130,6 & $\mathrm{H} 2 \mathrm{O}$ & 5 & $\mathrm{H} 2 \mathrm{O}+\mathrm{CO} 2$ & \\
\hline 37 & $-57,8$ & & & & 21,1 & (l) & & & 100 & $\mathrm{CO} 2$ & \\
\hline 38 & -58 & & & & 25,7 & (l) & & & 100 & $\mathrm{CO} 2$ & \\
\hline 39 & $-57,9$ & & & & 13,7 & (l) & & & 100 & $\mathrm{CO} 2$ & \\
\hline 40 & $-58,4$ & & & & 25,5 & (l) & & & 100 & $\mathrm{CO} 2$ & \\
\hline 41 & -59 & & & & 21 & (l) & & & 100 & $\mathrm{CO} 2$ & \\
\hline 42 & $-58,1$ & & & & $-0,9$ & (l) & & & 100 & $\mathrm{CO} 2$ & \\
\hline 43 & & & & & 27 & (l) & & & 100 & $\mathrm{CO} 2$ & \\
\hline $43 a$ & & & & & & & 227,2 & (l) & & & \\
\hline
\end{tabular}




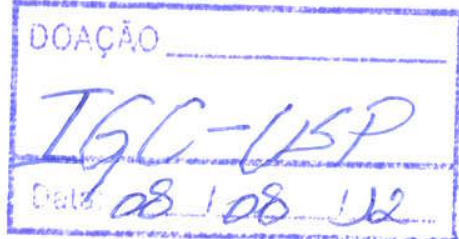

